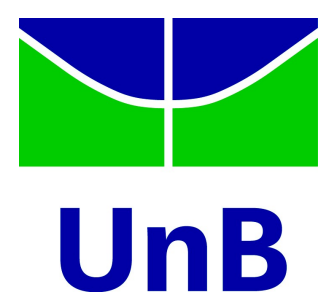

UNIVERSIDADE DE BRASÍLIA

FACULDADE DE COMUNICAÇÃO

PROGRAMA DE PÓS-GRADUAÇÃO EM COMUNICAÇÃO

PEDRO ANDRADE CARIBÉ

LEI DA TV PAGA: OS MEDIADORES NA CONSTITUIÇÃO DE UMA REDE AUDIOVISUAL 


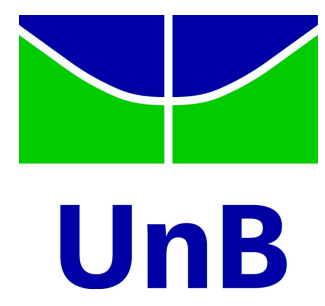

UNIVERSIDADE DE BRASÍLIA

FACULDADE DE COMUNICAÇÃO

PROGRAMA DE PÓS-GRADUAÇÃO EM COMUNICAÇÃO

PEDRO ANDRADE CARIBÉ

\title{
LEI DA TV PAGA: OS MEDIADORES NA CONSTITUIÇÃO DE UMA REDE AUDIOVISUAL
}

\author{
Dissertação apresentada ao Programa de Pós- \\ Graduação em Comunicação da Universidade de \\ Brasília (UnB) como requisito parcial para a obtenção \\ do Título de Mestre em Comunicação.
}

Orientadora: Profa. Dra. Elen Cristina Geraldes 
Caribé, Pedro Andrade.

Lei da TV Paga: os mediadores na constituição de uma rede audiovisual

-- Brasília, 2015.

xxix, 181f.

Dissertação (Mestrado) Universidade de Brasília. Faculdade de Comunicação. Programa de Pós-Graduação em Comunicação.

Título em inglês: The paid TV law: the mediators in the audio-visual net's constitution

1. Políticas de Comunicação e Cultura 2. Lei da TV por Assinatura 3.

Teoria Ator-Rede 4. Audiovisual 


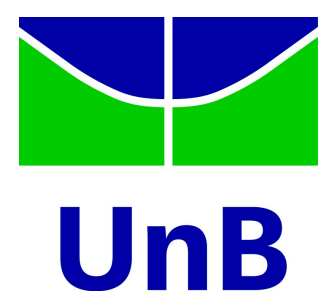

UNIVERSIDADE DE BRASÍLIA

FACULDADE DE COMUNICAÇÃO

PROGRAMA DE PÓS-GRADUAÇÃO EM COMUNICAÇÃO

\section{Diretor da Faculdade de Comunicação}

Prof. Dr David Renault.

\section{Coordenador do Programa de Pós-Graduação}

Profa. Dra. Thais de Mendonça Jorge 


\title{
BANCA EXAMINADORA
}

\section{PRESIDENTE DA BANCA}

\begin{abstract}
Profa. Dra. Elen Cristina Geraldes
Professora Adjunta do Departamento de Comunicação da Universidade de Brasília, Faculdade de Comunicação - FAC-UnB
\end{abstract}

\section{TITULARES}

\section{Profa. Dra. Ruth de Cássia dos Reis}

Professora Adjunta do Departamento de Comunicação da Universidade Federal do Espírito Santo Departamento de Comunicação - UFES

\section{Prof. Dr. Murilo César Ramos}

Professor Aposentado do Departamento de Comunicação da Universidade de Brasília, Faculdade de Comunicação - FAC-UnB

\section{SUPLENTE}

\section{Profa. Dra. Dácia Ibiapina da Silva}

Professora Adjunta do Departamento de Comunicação da Universidade de Brasília, Faculdade de Comunicação - FAC-UnB 
Ao menino e futuro homem, Heitor. 


\section{AGRADECIMENTOS}

A rede a que estou integrado é tecida muito além da vida de carne e osso, é composta por sonhos, ideias, espíritos e almas. Todos fluindo em muita água.

Começo pedindo permissão e agradecendo aos Orixás e Caboclos por conectar minha história terrena com desafios e prazeres sem tempo e espaço. Agradeço também aos membros da família Vintém por cuidar da conexão com estas entidades e me acolher independente da distância, em especial a Mãe Marlene.

Neste mundo, fui gestado nas águas do ventre de minha mãe, Flor. Esta dádiva sempre se fez com a doçura e compreensão a fim de me tornar uma pessoa melhor para mim e aos que me cercam.

Ao meu pai, Coió, devo o respeito e forças da espada para enfrentar um mundo nem sempre doce, mas em que a integridade e alegria de dona Wanda devem estar sempre presentes.

Aos meu irmão mais velho, Uel, e minhas irmãs caçulas, Jujuba e Maricota, por manterem uma irmandade olho por olho.

À Dani, meu amor e companheira, agradeço por estar ao meu lado nesta e outras tantas caminhadas. Só nós dois sabemos os desafios enfrentados, bem como a imensidão da alegria ao constituir uma família e acordar diariamente com o sorriso de nosso Heitor. Aos seus pais, 'seu' Vieira e dona Célia, pela ajuda e amor ao nosso filho.

Aos amigos que os caminhos se cruzaram na querida Bahia, vocês estão sempre presentes.

Nestes quase dois anos em Brasília, a rede a que estou integrado fortaleceu ou encontrou vínculos a serem cultivados. Ao colocar o pé na cidade fui acolhido de forma altruísta por Romana e Marcy, a elas tenho toda gratidão por permitir uma tranquilidade inicial nesta jornada. A Venício e a Murilo, os prazerosos encontros, a experiência, o apoio e o reconhecimento. A dona Eva, a mão permanentemente estendida. A Gésio, a rara lealdade e integridade. A Ju Nunes pela proteção. Ao 'cumpadre' Xica e à 'cumadre' Cleide, por perpetuarem a cumplicidade dos encontros aos nossos filhotes. A Laurita, pela amizade que atravessa o século. Aos Filhos de Lá Ele pela recepção generosa regada a dendê. Aos irmãos africanos, em especial Temothée e Arthur, por reconectar à infância.

Aos colegas, professores e funcionários da Universidade de Brasília que tiveram uma relação franca e propositiva, proporcionando crescimentos intelectual e humano.

À orientadora Elen Geraldes, por sua contribuição em todo o percurso, principalmente por entrar com firmeza, confiança e solidariedade neste e em futuros desafios.

À CAPES e ao CNPQ por conceder uma bolsa fundamental para o desenvolvimento do trabalho.

À FAP/DF por apoiar na participação de eventos acadêmicos.

Aos diálogos com Carla Gomide, Glauber Piva, Berenice Mendes e todos os entrevistados que cederam seu precioso tempo na constituição da rede "Lei da TV Paga".

Aos que lutam para ampliar a diversidade e pluralidade no audiovisual em circulação no país, principalmente aqueles que ainda não foram devidamente reconhecidos pelo Estado brasileiro. 
"Não sou prisioneiro da História. Não devo procurar nela o sentido do meu destino. Devo me lembrar, a todo instante, que o verdadeiro salto consiste em introduzir a invenção na existência. No mundo em que me encaminho, eu me recrio continuamente."

Frantz Fannon

(in Peles Negras, Máscaras Brancas,

2008 , p. 189) 


\section{RESUMO}

O tema deste trabalho é a configuração do conteúdo audiovisual no Brasil. Tal configuração é tratada parcialmente por meio da constituição da Rede "Lei da Tv Paga". Essa Rede foca os grupos que atuam diretamente no audiovisual através da produção, programação e difusão do conteúdo, e tem como modelo normativo a Lei 12.485/2011, mais conhecida como Lei da Tv Paga. A Teoria Ator-Rede (TAR) é responsável pela base do arcabouço teórico-metodológico, e, a partir dela, são selecionados, inicialmente, elementos como: reportagens, vídeos, artigos, pesquisas acadêmicas e entrevistas exclusivas. Tais indícios são relevados sem desmerecer a capacidade de agência dos fatores humanos e não-humanos. O segundo passo é sistematizar as pistas em quatro mediadores: (I) grupos sociais; (II) Estado; (III) arquitetura tecnológica; e (IV) circulação do conteúdo. Os vínculos estabelecidos entre os atores e actantes dos mediadores formam a rede "Lei da TV Paga". A terceira etapa é revisão revisão bibliográfica das pesquisas sobre cinema, televisão aberta e televisão por assinatura. Nessa revisão, foi possível descrever a presença elementos que constituem a Rede independentemente da estrutura moderna ou global, bem como uma concepção de audiovisual que desfragmenta a divisão entre políticas culturais e políticas de comunicação. $\mathrm{O}$ quarto momento é na passagem do milênio, quando alguns movimentos passam a constituir a rede com maior intensidade. A produção nacional e independente se fortalece nas transformações técnico-estéticas e mantém sua insatisfação com a políticas estatais após a criação da Ancine. $\mathrm{O}$ Ministério da Cultura passa a representar mais tais anseios, e responde em iniciativas como a II Ancinav, fortalecimento da comunicação pública e criação do FSA, todos lastreados pelo princípio da "Exceção Cultural" . O discurso em defesa da cultura nacional se cruzou com as Organizações Globo, em seu receio de perder espaço para grupos estrangeiros no seu movimento de saída da distribuição dos serviços de telecomunicações e sinergia em torno do conteúdo, porém não interessava avançar em reformas na TV aberta, e, sim, na manutenção do modelo de concentração, ratificado com a adoção do padrão de TV digital. Já a TV por assinatura formou uma identidade no conteúdo sob predomínio das majors estadunidenses e Globosat. Ela detinha um arranjo regulatório desatualizado, que serviu como ponto de partida para o Congresso Nacional debater, durante cinco anos, e aprovar a Lei da Tv Paga. Esta lei detém quatro pontos destacáveis para futuras reformas regulatórias, porém restritos à lógica de serviço privado: o primeiro deles é uma visão mais holística do audiovisual ao relacionar diversas plataformas e mecanismos de produção. O segundo é o aperfeiçoamento quanto aos perfis do conteúdo, em especial, ao adotar o conceito de espaço qualificado. $\mathrm{O}$ terceiro são os mecanismos novos ou aprofundados para estimular ou proteger o conteúdo audiovisual brasileiro, independente e regional. Por fim, o quarto é determinar limites à concentração na cadeia produtiva. Deste modo, o presente trabalho pretende contribuir com as pesquisas sobre a configuração do audiovisual e das Políticas de Comunicação e Cultura num cenário de entraves regulatórios.

Palavras-chave: Políticas de Comunicação e Cultura. Lei da TV por Assinatura. Audiovisual. Teoria Ator-Rede. 


\begin{abstract}
The theme of this work is the configuration of the audiovisual content in Brazil. That configuration is treated partially by the net of "Pay TV Law". It focuses in the groups that work directionally with the audiovisual through production, programming e diffusion of content, and has as model the law $12.485 / 2011$, knowing as the Pay TV Law. The theory Ator-Rede (TAR) is responsible by the base of the theoretical and methodological structure, and, from this theory the same elements are initially selected shuch as: news reports, videos, articles, academics researchers and exclusives interviews. Such evidence are revealed without debunk the act capacity of the human and non-human factors. The second step is to systematize the tracks in four mediators: (I) social groups, (II) State, (III) technological architecture; and (IV) content circulation. The establishment links among the actors and actants of the mediators form the net of "Pay TV Law". The third step is the bibliographic review of the research about cinema, open television and pay tv. With that review, was possible to describe the presence of elements that constitute the Net, independently of the modern or global structure, as well as the concept of audiovisual that breaks the division between cultural and communication politics. The fourth moment is the passage of the millennium, when some movements begin to be part of the net with more intensity. The national and independent production gets strong with the technical and aesthetically transformations and keeps its dissatisfaction with the state politics after the creation of ANCINE. The Ministry of Culture starts to represent more such demands, and responds with initiatives like the II ANCINAV, giving more power to the public communication, and the FSA, all of them broadcast by the principal of the "Cultural Exception". The speech in defense of the national culture had cross with Globo Organizations, in its fear of loose space for foreign groups in its movement of leaving the distribution of services of telecommunications and synergy around of content, however was not interesting advance in reforms for open TV, but the maintenance of the concentration model, rectified with the adoption of the standard of digital TV. The pay TV had formed an identity in the content with the predominance of the US majors and Globosat. The pay TV had the regulatory arrange outdated, that served as the start for the National Congress debate, for five years, and approve the Pay TV Law. That law has fourth important points for futures regulatory reforms, however, restricted to the logical of private services: the first is the more holistic vision of the audiovisual related with several platforms and production mechanisms. The second is the improvement of the profiles of content, in special, the adoption of the concept of qualify space. The third are the new mechanisms, or depth to stimulate or protect the Brazilian audiovisual content, independent or regional. Lastly, the fourth are determinate limits for the productive chain. Thus, the present work intend to contribute with the research about the audiovisual configuration and the Communications Politics and Cultural Politics in a setting of regulatory barriers.
\end{abstract}

Key words: Communication and Culture Politics. Paid TV Law. Audio-visual. Actor-Network Theory. 


\section{SUMÁRIO}

INTRODUÇÃO

CAPÍTULO I - REAGREGANDO UMA REDE AUDIOVISUAL 18

$\begin{array}{lll}1.1 & \text { METODOLOGIA } & 18\end{array}$

1.2 UMA CONTRIBUIÇÃO À ECONOMIA POLÍTICA DA COMUNICAÇÃO 21

1.3 A REDE E OS MEDIADORES 23

1.4 A JUSTIFICAÇÃO DA AÇÃO 29

1.5 A CONVERGÊNCIA COMO DESPOLITIZAÇÃO DA TÉCNICA E 'DESTECNIFICAÇÃO' DA POLÍTICA

1.6 “CULTURA DO SILÊNCIO"

1.7 A CIRCULAÇÃO TRANSMEDIADA

1.8 MEIOS E TÉCNICAS DA PESQUISA 37

CAPÍTULO II - DO MODERNO AO GLOBAL

2.1 O CINEMA MODERNO 42

2.1.1 POLÍTICA INTERNACIONAL DOS GOVERNOS MILITARES A SARNEY 47

2.1.2 Cinema E GLOBALIZAÇ̃̃o 50

2.2 A TV MODERNA $\quad 54$

2.2.1 O MODERNO NÃO É NOVO

2.2.2 A MODERNIDADE DO ATRASO 64

$\begin{array}{lll}2.3 & \text { A TV GLOBAL } & 73\end{array}$

CAPÍTULO III - DISPUTAS E ASSOCIAÇÕES ANTES DA LEI 81

3.1 A RETOMADA DA CRISE

3.2 "O POVO DO CINEMA" E III CBC 84

3.3 A NOITE DO DELETE

3.5 AS EXPECTATIVAS NA TRANSIÇÃO

3.6 O MOVIMENTO DE SAÍDA DA GLOBO NA DISTRIBUIÇÃO 91

$\begin{array}{lll}3.7 & \text { A SINERGIA DA GLOBO } & 95\end{array}$ 
3.9 A CONVENÇÃO DA DIVERSIDADE

3.10 O FUNDO SETORIAL DO AUDIOVISUAL 105

3.11 A TV PÚBLICA NACIONAL 106

3.12 A DIGITALIZAÇÃO ANALÓGICA 107

3.13 AS ASSOCIAÇÕES DOS INDEPENDENTES

CAPÍTULO IV - A REDE SE CONSTITUI E TRANSBORDA

4.1 OS TRÊS PROJETOS BASE

4.1.1 “O TRATAdo DE TORDESILHAS" 116

4.1.2 A RESERVA NA PROGRAMAÇÃO 117

4.2 O RELATÓRIO FINAL DE BITTAR 119

$\begin{array}{lll}4.2 .1 & \text { A RADIODIFUSÃO } & 120\end{array}$

4.2.2 VALORIZAÇÃO DO CONTEÚDO BRASILEIRO E INDEPENDENTE 121

4.2.3 A DISPUTA EM TORNO DAS COTAS NO EMPACOTAMENTO 123

4.3 COMISSÃO DE DEFESA DO CONSUMIDOR 126

4.4. O RELATÓRIO DE LUSTOSA

4.5 OS ÚLTIMOS PASSOS ATÉ SANCIONAR A LEI

4.6 OS DIREITOS AUTORAIS

4.7 A REDE É NORMATIZADA

4.7.1 AS COTAS NA PROGRAMAÇÃO E EMPACOTAMENTO 137

4.7.2 OS VÍNCULOS DA DISTRIBUIÇÃO COM O CONTEÚDO 143

4.8 OS TRANSBORDAMENTOS

CONSIDERAÇÕES FINAIS

REFERÊNCIAS BIBLIOGRÁFICAS

ANEXO - Lei. 12.485/2011 166 


\section{INTRODUÇÃO}

O tema desta dissertação é a configuração do conteúdo audiovisual no Brasil. Tal configuração será tratada parcialmente por meio da constituição da Rede "Lei da TV Paga". Essa Rede foca os grupos que atuam diretamente no audiovisual através da produção, programação e difusão de conteúdo, e tem como modelo normativo a Lei 12.485, sancionada no dia 12 de setembro de 2011, e mais conhecida como Lei da Tv Paga.

O dispositivo unificou as regras nos serviços de distribuição da TV por assinatura, independente da tecnologia adotada (cabo, satélite ou ondas eletromagnéticas). Assim, criou o Serviço de Acesso Condicionado (SeAC) em conformidade às reivindicações das empresas de telecomunicações ${ }^{1}$ de consolidar um quadro já presente no mercado: permitir a exploração conjunta da telefonia fixa com a TV a cabo, bem como a entrada irrestrita do capital internacional nessas atividades.

Curiosamente, o ponto de partida na constituição desta Rede é a ausência das teles. Para seus anseios prosseguirem no Congresso Nacional, aceitaram contemplar o principal grupo nacional em atuação nas atividades da Rede: as Organizações Globo. Dessa forma, a Lei da Tv Paga impõe às teles duras restrições para controlar radiodifusoras, produtoras e programadoras, assim como impede de contratar talentos artísticos, e adquirir quaisquer direitos de obras audiovisuais de autores brasileiros ou de grandes eventos esportivos ou culturais.

O receio da Globo era perder espaço no conteúdo para empresas com faturamento cerca de dez vezes superior. Mas na prática tal receio era especulativo, porque não havia um movimento contundente das teles em investir no conteúdo. Também foi formal para a Globo o impeditivo expresso na Lei da Tv Paga dos radiodifusores controlarem os serviços de telecomunicação, porque na prática ela também estava em processo de retirada destas atividades.

A importância crucial na Rede desta divisão de papéis entre teles e Globo, apelidada “Tratado de Tordesilhas”, é demarcar a atuação dos grupos na exploração direta do conteúdo audiovisual, conceituado sem distinções conforme os processos de captação ou meios de veiculação ou reprodução..

A relação da Lei da Tv Paga com uma visão mais ampla do conteúdo audiovisual também está presente na produção, mais especificamente nas fontes de fomento. Ela foi responsável em redirecionar a arrecadação oriunda das atividades das empresas de telecomunicações para o Fundo Setorial do Audiovisual (FSA). Dessa forma, a Contribuição para o Desenvolvi-

1 Oi, Telefônica, GVT, Claro, Embratel e Net Serviços eram as principais interessadas nesta alteração. 
mento da Indústria Cinematográfica Nacional (Condecine), base do FSA, saltou de R\$ 43 milhões em 2011 para R \$ 806 milhões em 2013, destinados majoritariamente para o fomento de filmes, séries, documentários e animações. Tal volume de dinheiro foi suficiente para lastrear o Programa Brasil de Todas as Telas, lançado em 2014 pelo governo federal como símbolo da pujança audiovisual do país.

Iniciado em 2006, o FSA é um instrumento que permite ao Estado ter participação mais efetiva na destinação do fomento, e assim, apresenta uma alternativa aos mecanismos de renúncia fiscal adotados na década de 1990. O Fundo é administrado pela Agência Nacional do Cinema (Ancine), adota uma série de critérios para alocar os recursos, sendo o primordial favorecer o conteúdo nacional e independente. A contribuição da Lei da Tv Paga nesse sentido foi complementar os instrumentos vigentes e conceituar o que são produtoras brasileiras e independentes a fim de resguardar a exclusividade no acesso ao fomento e as relações com os direitos autorais. No Brasil, o ideal da produção independente atravessa seis décadas, e encontrou sua fórmula legal na Lei 12.485 ao ser aquela reconhecida por apoio estatal via fomento, e não ser controlada ou sem contrato de exclusividade com radiodifusores ou programadores. Dessa forma, fica impedido à Globo Filmes e majors como Warner, Fox e HBO conseguirem acessar diretamente os programas gerenciados pelo FSA.

Mais ainda, a Lei 12.485 reserva $30 \%$ dos recursos originários do Condecine às produtoras estabelecidas nas regiões Norte, Nordeste e Centro-Oeste, a fim de responder às críticas quanto a concentração no eixo Rio-São Paulo endossada nas políticas nacionais fincadas na década de 1990. Também reserva 10\% dos recursos totais da Condecine para a produção veiculada primeiramente nos canais comunitários, universitários e de programadoras brasileiras independentes da TV por assinatura em consonância com o movimento de fortalecimento de campo de interesse público marcado pela criação da Empresa Brasil de Comunicação (EBC).

Ainda no FSA, outro critério chave para destinar os recursos no fomento é a apresentação, por parte dos produtores, do plano de distribuição envolvendo canais de televisão e salas de cinema. E isso toca num problema nevrálgico e histórico no país: a ausência de meios para desaguar o conteúdo independente brasileiro.

A solução da Lei da Tv Paga foi não mexer num ponto intocável para a Globo e quaisquer outro grande grupo de radiodifusão no país: a regulamentação do Art. 221 da Constituição Federal que prevê a valorização da produção independente e regional. Também não tocou em regras nos serviços emergentes como Netflix. A solução fecha o fluxo majoritário desta Rede no conteúdo que circula sob princípios privados, entregue exclusivamente para assinantes do SeAC. 
Nesse conteúdo foram instauradas cotas na programação, bem como no empacotamento dos canais. Tal aplicação de reserva é algo inovador no país, e segue um panorama dos organismos multilaterais legitimarem os governos nacionais aplicarem tais mecanismos no audiovisual em prol da promoção e proteção da diversidade cultural. O alvo principal são os canais que ofertam predominantemente formatos com maior potencial econômico: séries, animações, reality-shows, documentários e filmes de ficção em longa-metragem. No caso desse último produto, ele continua a ser primordial no mercado das salas de cinema, por isso, a Lei da Tv Paga, além de fomentar tais obras, tem relação objetiva com os negócios desse parque exibidor.

Na TV por assinatura, essas cotas respingam mais nos canais estrangeiros, basicamente estadunidense, que por sua vez são majoritários na grade. Quanto ao canais Globosat, seu protagonismo entre os grupos nacionais não foi ameaçado, ao contrário, foi endossado, porque as cotas reservam seu espaço no empacotamento e não preveem um fortalecimento significativo dos canais independentes. Para completar, o conteúdo apto a cumprir as cotas é preponderantemente originário de recursos públicos administrados pela Ancine. O investimento dos canais é quase nulo para cumpri-las.

Por fim, a Rede volta se abrir e transbordar nas regras e natureza do SeAC. Os canais abertos têm carregamento fácil de ser assegurado, seja por caminhos burocráticos, seja por importância para o consumidor, pois ainda são responsáveis por maiores audiências no serviço. Ou seja, a televisão aberta está presente neste ambiente. Presença também do conteúdo ofertado aos assinantes fora da sua residência, pois as programadoras da TV paga paulatinamente permitem usufruir do produtos nas plataformas móveis.

O leitor que chegar até aqui pode estar se perguntando: "Isto aqui é uma conclusão com os resultados da Lei 12.485/2011?”. Rigorosamente, as definições ou impactos da Lei não compõem o objeto da dissertação. Provavelmente um profissional que acompanha cotidiano deste cenário no mercado, política ou em aparato regulatório tem mais propriedade para analisar os "porquês" de cada ponto da Lei, e suas relações com os atores econômicos.

O problema que permeia toda a pesquisa é: como a Rede audiovisual "Lei da Tv Paga" se constitui? O "como" ao invés do "porquê" permite à pesquisa se desvencilhar de verdades pré-estabelecidas num cenário de constates transformações na configuração do audiovisual e ao mesmo tempo entraves regulatórios que cercam esse setor. Durante as páginas a seguir vamos tentar descrever e analisar o processo que permitiu tal configuração audiovisual, e isso incluí e ressalta o Estado e as corporações, mas não os tornam exclusivos. 
O aporte teórico-metodológico para descrever e analisar como seu deu o processo é fornecido principalmente pela Teoria Ator-Rede (TAR). A noção de rede, ao invés de estrutura ou sistema, permite estar aberto a considerar os vínculos presentes no processo sem desmerecer a capacidade de agência de fatores humanos e não-humanos, a exemplo das tecnologias e símbolos. Por isso, tal Rede audiovisual é composta por quatro mediadores que congregam os atores e actantes mais identificados na constituição: (i) grupos sociais, (ii) Estado, (iii) arquitetura tecnológica, e (iv) circulação do conteúdo. Eles são introduzidos e descritos sinteticamente no Capítulo I - "Reagregando uma rede audiovisual”. No mesmo capítulo vamos apresentar os outros conceitos chave que norteiam a identificação dos mediadores: cultura do silêncio; transmediação; bem como uma crítica à utilização do paradigma da convergência.

No Capítulo II - "Do moderno ao global” -, a Rede assume dimensão histórica por meio de pesquisas sobre cinema, televisão aberta e por assinatura no país entre a década de 1950 e a passagem para o século XXI. Veremos como a configuração do audiovisual esteve associada a segmentação dessas plataformas às políticas de comunicação e cultura nas estruturas conceituais da modernidade e globalização. Também veremos como é possível reconectar historicamente a rede através dos mediadores.

No Capítulo III - "Disputas e associações antes da Lei" - foram contextualizadas pesquisas, reportagens, leis, conteúdos audiovisuais, informações do mercado, documentos e entrevistas que descrevem os movimentos dos mediadores num período anterior à sanção da Lei 12.485/2011. Essa etapa da investigação objetivou demonstrar como foram formadas singularidades da Rede fortalecidas com a adoção do seu dispositivo normativo.

Já no Capítulo IV - “A rede se constitui e transborda” -, é descrita a tramitação da Lei 12. 485/2011 com a contribuição fundamental de atores que participaram ou acompanharam diretamente o processo. Por meio dos relatos, foi possível subsidiar a escolha da dissertação em realçar determinados pontos estratégicos da Rede, responsáveis por conflitos e consensos. Esses materiais também permitiram descrever e analisar transbordamentos da rede responsáveis por colocar os limites da Lei 12.485 para reconhecer e formar redes mais extensas relacionadas ao audiovisual.

É necessário destacar que o trabalho a seguir não se propõe uma neutralidade científica. Entendemos que qualquer ação humana é inserida no contexto de sua produção e que passa, necessariamente, pelo crivo do pesquisador que realiza escolhas a cada etapa de seu trabalho. Este estudo está imerso num panorama de entraves regulatórios, no qual se buscou descrever ao máximo os elementos que compõem o cenário, ampliar as possibilidades para 
compreender o processo e aprofundar a compreensão da legislação em foco como fenômeno das políticas de comunicação e cultura.

Igualmente, assinalamos, de antemão, alguns limites da pesquisa. Trata-se de uma dissertação de mestrado, vulnerável aos prazos, ao estado do conhecimento do pesquisador, ao programa e até às investigações em comunicação no país. Nessa perspectiva, é raro galgar integralmente todos os objetivos estabelecidos de início. Assim, o passo dado é só o primeiro de uma longa caminhada, com o qual, buscamos contribuir para a compreensão dos processos focalizados, bem como de processos sociais equivalentes.

Ainda assim, espera-se que isso não invalide a tentativa de encontrar mais elementos para compreender os entraves e os caminhos das transformações nas comunicações e cultura. Espera-se que a dissertação possa ampliar as possibilidades de pesquisa, atenuando as dificuldades autorreconhecidas da academia em acompanhar os embricamentos do mundo digital e as reivindicações sociais. 


\section{CAPÍTULO I}

\section{REAGREGANDO UMA REDE AUDIOVISUAL}

Neste capítulo, vamos apresentar o elemento chave para a descrição da Rede: a metodologia. A referência, nesse sentido, está na Teoria Ator-Rede, e é por meio dela que buscaremos identificar os elementos presentes na constituição da "Lei da TV Paga". Esses elementos vão ser sistematizados em quatro mediadores: (i) grupos sociais, (ii) Estado, (iii) arquitetura tecnológica, e (iv) circulação do conteúdo. Os vínculos envolvendo os atores e actantes que compõem os mediadores serão resumidamente descritos para facilitar a leitura no decorrer da dissertação. A descrição das conexões entre os mediadores parte de crítica ao paradigma da convergência. No caso da valorização do Estado na normatização da Rede, permite identificar o trabalho como contributo à Economia Política da Comunicação.

\subsection{METODOLOGIA}

Lidar com o panorama envolto na "Lei da TV Paga" estimula buscar instrumentos teórico-metodológicos que extrapolem as fronteiras da literatura moderna majoritária e possam auxiliar os pesquisadores num denso e veloz processo de transformação das comunicações eletrônicas e práticas culturais. A princípio, esta pesquisa não está norteada pela ideia de fim da modernidade. Ela se desenvolve reconhecendo que os mecanismos da ciência social tradicional continuam a influenciar a realidade. A questão é que o pensamento moderno não tem mediado a superação de alguns entraves, a começar pela dificuldade em descrever e superar as transformações em curso.

Por isso, décadas depois dos frankfurtianos, uma geração resgata a ideia da crítica, enquanto reflexão da modernidade, todavia, sob bases epistemológicas e contextos distintos. John Law, Michel Callon e Bruno Latour são os principais expoentes da sociologia da Teoria 
do Ator-Rede (TAR), ou sociologia da tradução, a qual norteia a metodologia desta dissertação.

O método tem papel chave para a TAR nesse sentido. A preocupação de Law (2004) é descrever de forma profunda e densa os problemas colocados à ciência. Ele aposta que o método seja o caminho chave para a ciência se reformular e assumir humildemente que a sua missão de ordenamento do mundo chegou ao limite. Segundo o autor, a ciência já não consegue dar respostas satisfatórias às questões, e precisa assumir sua responsabilidade no atual estágio das coisas. Não é uma visão derrotada, ou politicamente conformista, mas, uma resposta possível aos impasses científicos.

Essas limitações, para Law (2004), foram auto-reconhecidas em grandes pensadores como Karl Marx, Georg Simmel, Max Weber, Georg Lukács, George Herbert Mead e Walter Benjamin. Eles sempre tiverem consciência dos limites das suas ideias:

Isso quer dizer que, de diferentes maneiras, eles respondiam à ideia de que o mundo era tão complexo que nossas teorias sobre ele sempre iriam falhar em apreender mais de uma de suas parte; que, por isso, há uma gama de possível teorias acerca da gama de possíveis processos; que essas teorias e processos são, provavelmente irredutíveis a um outro; e, finalmente, que nós não podemos transcender o mundo para obter uma 'visão integral de lugar nenhum' que englobasse todas as teorias e processos juntos. ${ }^{2}$ (LAW, 2004, p. 8, tradução nossa)

O objetivo de Law (2004) é retomar esse horizonte e tentar desenvolver um ponto de vista sobre os problemas, e não uma visão geral. Para isso, a relação com o método não incorpora a percepção tradicional, que o concebe como o rigor adotado para chegar à determinada realidade. Ele deseja despir o método da pretensão de ser um processo de higienização que pretende tornar a pesquisa limpa de qualquer contaminação social ou científica, como a subjetividade do pesquisador ou as influências dos valores e normas de um campo científico.

Para Latour e Woolgar (1997), o primeiro passo do método é desvendar ou relevar a etnografia dos cientistas na construção do conhecimento. O procedimento-chave é uma descrição aprofundada para a compreensão dos atores e actantes que compõem uma rede e dos elos que estes mantêm entre si. O resultado não tem a pretensão de ser exaustivo ou absoluto,

2 No original: "This means that in different ways they responded to the idea that the world is so rich that our theories about it will always fail to catch more than a part of it; that there is therefore a range of possible theories about a range of possible processes; that those theories and processes are probably irreducible to one another; and, finally, that we cannot step outside the world to obtain an overall 'view from nowhere' which pastes all the theory and processes together" (LAW, 2004, p. 8). 
mas considera o caminho percorrido pelo pesquisador, a disponibilidade de recursos, o tempo, o acesso às fontes e a até o papel da linguagem nesse mecanismo de construção do saber.

No caso desta dissertação, boa parte da pesquisa é direcionada para definição e revisão bibliográfica. As disciplinas cursadas foram centradas nos programas de pós-graduação em Comunicação e Sociologia da Universidade de Brasília. E os espaços de coleta de bibliografia se expandiram para as reuniões com os orientadores, internet e a própria biblioteca da universidade, que, por sinal, foi o principal recinto nos estudos.

Todavia, este processo de confinamento tende a construir uma realidade assimétrica em relação ao que os atores envolvidos no tema do estudo reconhecem. O distanciamento desta disfuncionalidade começa na linha de um curso de pós-graduação reconhecido por aglutinar ativistas e gestores nas políticas de comunicação, e, até mesmo, participar cotidianamente na construção das políticas, sob acompanhamento empírico. O segundo elemento está na trajetória do pesquisador.

Dessa forma, o trabalho incorpora a reflexão ulterior às ciências e adota o conceito de "coperformatividade" de Michel Callon (2009). O legado positivista da objetividade e neutralidade é, então, questionado por Callon, e, consequentemente, a possibilidade explicativa da realidade. Ao utilizar a economia como um dos seus escopos de pesquisa, ele aponta que sua existência é precedida por "elaboração e implementação do conhecimento, das afirmações e das representações que a faz existir como um objeto simultaneamente de conhecimento e intervenção" (CALLON, 2009, p. 389). Ou seja, a economia só existe como tal devido às influências das ciências econômicas.

Uma questão subsequente está na participação de atores humanos e não-humanos nas ciências, além do especialista na disciplina:

\footnotetext{
é preciso adicionar todo este trabalho acadêmico realizado por aqueles que atuam nas disciplinas relacionadas com a Economia, como Administração, e todos aqueles que estão no campo - profissionais da computação, profissionais de mercado, movimento sociais etc. -, que desenvolvem conhecimentos e competências altamente formalizadas, sistemáticas e abstratas, assim como também aparelhos técnicos e que proporcionam à Economia toda a sua robustez e sua identidade. (CALLON, 2009, p. 389)
}

Esta última questão é importante para demonstrar que a construção deste trabalho não é uma tarefa isolada do pesquisador. Existe um constante acompanhamento do cenário em questão. Mais ainda, boa parte dos insights são estimulados por reflexões daqueles que atuam na rede. Gestores, tecnologias, documentos, reportagens, profissionais, ativistas e acadêmicos têm suas trajetórias acompanhadas. 


\subsection{UMA CONTRIBUIÇÃO À ECONOMIA POLÍTICA DA COMUNICAÇÃO}

O conceito de "coperformatividade" adotado por Callon (2009) significa uma relação estreita da ciência na construção da realidade. Nesse sentido, a valorização do Estado e os processos econômicos dos atores políticos envolvidos na rede permite inserir este trabalho no escopo da Economia Política da Comunicação (EPC). Sinteticamente, vamos demonstrar porque isso se-coaduna com a construção da EPC ao longo da história.

Inicialmente, as abordagens da EPC tiveram salvaguarda no conceito de imperialismo cultural, formulado por Herbet Schiller ainda na década de 1960. Esse conceito viria a influenciar estudos relevantes para os países categorizados como de Terceiro Mundo no período. O objetivo político envolto era combater o postulado liberal-funcionalista do "free flow of information", desenvolvido primordialmente na Escola de Chicago sobre objetivos políticos militares (MATTELART, 2006).

Os dois conceitos citados anteriormente - imperialismo cultural e livre fluxo - foram relevantes na Organização das Nações Unidas (ONU) durante a elaboração do relatório "Um Mundo e Muitas Vozes" (1983). O imperialismo cultural, considerado por Mattelart (2006), expoente da EPC, é utilizado para questionar as estratégias de ajuda e de transferência de padrões civilizatórios. A proposta da EPC é formular noções de desenvolvimento que não levam em conta o acúmulo de capitais, mas as satisfações básicas do homem, incorporadas na Nova Ordem Mundial da Comunicação e Informação (MELO, 1998).

O crescimento do imperialismo cultural na UNESCO levou ao seu esvaziamento a partir da retirada das nações com maior peso econômico e político na sua manutenção: EUA e Inglaterra. No mesmo período os Países Não Alinhados se desarticularam nos fóruns internacionais, e as teorias do livre fluxo passam a predominar repaginadas na formulação do conceito de Sociedade da Informação, conforme apontam Briggs e Burke (2006). O esvaziamento do debate foi tamanho que nem mesmo as formulações que tocavam no desenvolvimento mais influenciadas pelo funcionalismo tiveram apoio.

Diante deste quadro de paralisia nos debates das políticas de comunicação e cultura nos fóruns internacionais, a EPC, embora menos influente, interessou-se gradativamente por ir na contramão e delinear as características e objetivos da intervenção pública no sistema comunicacional. O esgotamento conceitual da tese do imperialismo cultural levou parte dos teóricos críticos, inclusive o próprio Herbert Schiller, a aprofundar a percepção do Estado e da economia. Para Schiller (1986), a ação do Estado, especialmente no setor de informação, é variável conforme o desenvolvimento do mercado dentro de padrões históricos regionais, porém 
o papel nas sociedades capitalistas é sempre de ajudar o capital. A partir de então, os impactos dos fenômenos econômicos também assumiram centralidade para caracterizar a relação dos aparatos comunicacionais com o Estado.

Nos anos 2000, a realização de duas cúpulas mundiais sobre a Sociedade da Informação marca uma rearticulação dos debates internacionais quanto ao direito à comunicação. Já os direitos culturais tinham demarcado seu espaço ao aprovar o termo de "exceção cultural" nas diretrizes formadoras da Organização Mundial do Comércio (OMC) na década de 1990. Tais aberturas se constituem enquanto terreno fértil para o reavivamento da EPC, mais ainda, quando governos democráticos trazem uma plataforma de direitos historicamente das suas bases sociais para a agenda institucional.

No Brasil, isso ocorreu com mais força a partir do primeiro governo Lula (20022006). São diversos os exemplos de formuladores relacionados com a EPC que participaram, em alguma medida, dos debates regulatórios diretamente, ou indiretamente, na voz de representantes de organizações sociais, políticos e gestores, num caminho traçado, desde a década de 1990, com a participação e formulação de acadêmicos como Murilo César Ramos na Lei do Cabo.

No caso da Lei 12.485/2011, no ano de 2010 a Secretaria de Assuntos Estratégicos da Presidência da República realizou o seminário "Produção de Conteúdo Nacional para Mídias Digitais" com representantes empresariais, gestores públicos e pesquisadores que dialogam com a EPC: Valério Britto, Murilo Ramos, Cesar Bolaños e Marcos Dantas. Neste momento, a Lei da TV Paga já estava encorpada no Congresso Nacional, e o seminário resultou numa publicação com o mesmo título do seminário (2010), que contou com artigos dos pesquisadores acima mencionados, como exemplos concretos de que os pesquisadores da EPC não estavam alijados dos debates normativos.

Não se pretende, com isso, minimizar as formulações da EPC, ao contrário, o objetivo, aqui, é reconhecer as potências normativas, inclusive, ao se relacionar com a positivação de direitos e a busca por desemudecer a "cultura do silêncio". Também não se pretende buscar uma ciência distante da política e da economia. A crítica envolta na Teoria Ator-Rede não é um retorno ao paradigma de separação entre a ciência, cultura e tecnologia em busca de uma razão pura. Ao contrário, se trata de buscar caminhos que valorizem os discursos daqueles envolvidos nos processos sociais, e assumir a academia como mais um dos operadores de agenciamento nas redes, e, por consequência, no Estado e nas relações econômicas. 


\subsection{A REDE E OS MEDIADORES}

Na busca por uma metodologia singular para tecer a Rede "Lei da TV Paga", este trabalho utilizou uma revisão antropológica entre natureza e sociedade da TAR para traçar um diálogo de abordagens tratadas usualmente como distintas, mas que se referem aos mesmos problemas.

Latour (1994) destaca que o modelo de segmentação se filia ao pensamento "moderno" por representar dois conjuntos de práticas distintas e complementares: hibridismo e purificação. Ele vai tentar identificar e desfazer essa dialética, que tem como síntese a purificação e o ordenamento das relações e processos de natureza híbrida, inclusive no ambiente comunicativo. A fim de mergulhar na natureza híbrida, adota-se a noção de tradução ou rede: "Mais flexível que a noção de sistema, mais que a de estrutura, mais empírica que a de complexidade, a rede é o fio de Ariadne dessas coisas confusas” (LATOUR, 1994, p. 9).

Latour (2012) é signatário de uma corrente influenciada por Gabriel Tarde (18431904), que busca ressignificação do social numa lógica de associação e reagregação. O social não é mais uma estrutura que explica o funcionamento de uma organização, e, sim, um arranjo em que os objetos dão significado prático ao que representam ao serem inseridos em contextos distintos. Ser social é um movimento que, nem sempre, forma um conjunto denso, ao contrário, geralmente é fluído, reflexivo e mutável. O social forma redes, nas quais as fronteiras entre grupos são incertas.

A busca por relações causais, a partir da separação entre sujeito e objeto é substituída por uma noção de vínculos. As associações também se dão por vínculos não "formais" como a tecnologia e os símbolos, pois as relações sociais não são formadas meramente por uma natureza comunicativa interpessoal. Os não-humanos também operam agenciamentos, todavia, são ações de caráter distinto. Os fatos e as máquinas são meio-objetos e meio-sujeitos, pelos quais as noções de espaço sofrem revisões, a fim de compreender organizações, mercados e grupos sociais:

no caso das redes técnicas, não temos a menor dificuldade em reconciliar seus aspecto local e sua dimensão global. São compostas de locais particulares, alinhados através de uma série de conexões que atravessam outros lugares e que precisam de novas conexões para continuar se estendendo. Entre as linhas da rede não há nada, há rigor: nem trem, nem telefone, nem dutos, nem televisão. As redes técnicas, como o nome já diz, são redes de caça jogadas sobre espaços e que deles retêm apenas alguns elementos raros. São linhas conectadas, e não superfícies. (LATOUR, 1994, p. 115) 
A fluidez da rede ganha forma na medida em que determinados pontos do espaço retroalimentam o fluxo. Esse movimento acaba por criar singularidades internamente na rede, e, ao mesmo tempo, o movimento de pontualização é dotado de determinada autonomia, e, assim, capacidade para formar outras redes com outros fluxos e pontos. Para descrever esses pontos, vamos utilizar o conceito de mediadores. Eles são responsáveis por estabelecer um diálogo aberto entre a fluidez dos atores e actantes envolvidos na rede, mas sem neutralidade. Eles são operadores de agenciamento performatizados também por atores e actantes dotados de interesses peculiares e identificados a partir de uma lógica cartográfica:

não podem ser contados como apenas um, eles podem valer por um, por nenhuma, por várias ou uma infinidade... sua especificidade precisa ser levada em conta todas as vezes. Os mediadores transformam, traduzem, distorcem e modificam o significado ou os elementos que supostamente veiculam. (LATOUR, 2012, p. 65)

$\mathrm{Na}$ constituição da Rede por esse trabalho os atores e actantes vão ser apresentados nos quatro mediadores destacados: (I) grupos sociais; (II) Estado; (III) arquitetura tecnológica; e (IV) circulação do conteúdo.

A rede aqui descrita só faz sentido com os quatro mediadores. Sem os vínculos intercalados por um deles, os demais perdem a singularidade da ação e a consequente relação holística que perpassa toda rede. Entretanto, não se trata de uma relação de poder equânime entre os mediadores, e tampouco entre os atores e actantes. O radicalismo de Bruno Latour é, então, ponderado por Michel Callon (2007, p. 312), ao apontar hierarquias na sociologia da tradução:

Desde logo, não desconhecemos que há relações de dominação entre as agências e que algumas delas são capazes de impor formas de agenciamento sobre outras agências, ou de excluir outras agências ou formas de agenciamento, etc. O mercado econômico e a política desempenham um papel importante nesta geopolítica do agenciamento.

Nesta pesquisa, fatores políticos e econômicos acabam por perpassar, de forma preponderante, a composição da rede, principalmente na movimentação dos mediadores: (i) grupos sociais e (ii) Estado. Por outro lado, as técnicas e os símbolos, mais presentes na dinâmica da (iii) arquitetura tecnológica e (iv) circulação do conteúdo, detém agência na rede. Mais ainda, a correlação entre as diversas formas de agência é fundamental para enfrentar práticas de purificação recorrentes da modernidade, bem como da globalização, que, por sua vez, traz ele- 
mentos comuns na formulação do conhecimento. ${ }^{3}$ Uma das faces dessas práticas é separar o debate político e técnico, ou político e simbólico, inviabilizando uma leitura integrada sobre os problemas.

\section{Grupos sociais}

A "Lei da TV Paga" relaciona diversas plataformas numa rede integrada, todavia, coloca limites à concentração e reafirma a existência dessas plataformas. A pertinência dessas plataformas não se resume às questões técnico-estéticas. Em grande medida, elas são acompanhadas pela formação de grupos permeados de atores sob interesses e lastros específicos.

Nessa pesquisa foram tomadas como referência as usuais plataformas de comunicação: cinema, radiodifusão e TV por assinatura. Ao longo do texto, vamos demonstrar como essas plataformas vão movimentando suas fronteiras, reconfigurando seus atores e actantes, porém, mantém um núcleo político e econômico no formato empresarial, sob modelo de organização liberal, balizado na propriedade privada e vinculado às práticas de exclusão dos discursos preponderantes da modernidade e da globalização.

A constituição da Rede, lastreada pelo regime privado e relações de consumo com os usuários, por si só repele a contribuição dos movimentos sociais, lastreados por reivindicações de direitos de caráter público e participação cidadão com o conteúdo audiovisual. Dessa forma, eles aparecem pontualmente na descrição.

\section{Cinema}

A constituição da rede reconhece demandas do cinema, um grupo que pode ser dividido em dois subgrupos. ${ }^{4}$ Um se autodeclarava cinema nacional e, paulatinamente, passou a

3 Raewyn Connell (2010) tece alguns elos entre os discursos hegemônicos da modernidade e globalização. Ela demarca que a sociologia moderna predominante está embutida num projeto de dominação e colonização da Europa, e, posteriormente, dos EUA, em relação ao resto mundo, em especial, o Sul. Antes da II Guerra Mundial, a sociologia agia no seio de uma política cultural que tinha como ideia central a diferença entre a civilização da metrópole e as outras culturas primitivas. O objetivo era compreender as origens da sociedade moderna, os elementos causais que a levaram a tal estágio, por meio de método comparativo hierarquizante empregado em teorias gerais de teor universalizante, a partir de lugar de fala do/a pesquisador/a. Após a II Guerra, os EUA se tornaram a nova potência, e a Escola de Chicago emergiu. A sociologia, enquanto metaciência, perdeu espaço para se tornar um departamento, entre outros tantos, preocupados, majoritariamente, com pesquisas empíricas, e as teorias da ação social passaram a utilizar um método interessado em depurar as distinções entre sociedades urbanas e rurais, também sob teor generalizante. Para a autora, a globalização é relacionada com a linguagem midiática e a ação de empresários, a partir da crise Petróleo (1979) e crescimento do neoliberalismo. Nesse período, a sociologia retomou a sina de querer falar sobre o mundo inteiro, a partir de dois caminhos: (i) Se dedica a urbanização, mudanças nos mercados e nas elites econômicas; e (ii) a linha mais popular, que reifica a ideia de globalização como nova forma de sociedade marcada por mudança no sentido do Estado nação, processos de integração, fim de fronteiras e reflexividade entre atores políticos.

4 Não foi encontrada terminologia "subgrupos" nos textos da ATR. E, realmente, pode passar ao leitor uma representação de inferioridade na descrição. Não é essa a intenção. $O$ termo subgrupo serve mais para 
adotar uma visão de audiovisual independente e nacional; inicialmente sua representatividade é realçada na presença individual do diretor, paulatinamente se expande ao assumir formato mais empresarial e também maior capacidade de incidência no Estado. Outro subgrupo era reconhecido como cinema internacional, ou estrangeiro; ancorado em Hollywood, forma uma extensa indústria que tem o cinema historicamente como plataforma chave no Brasil e a partir da década de 1990 se expandiu na TV por assinatura.

\section{Radiodifusão}

$\mathrm{Na}$ descrição dos radiodifusores, vamos explorar os motivos que levaram o modelo comercial predominar em relação ao público e estatal. As principais emissoras na história do país são resgatadas para levar ao leitor os elementos chave na formulação do ideal de modernidade. A partir da década de 1990, a televisão aberta passou por readequação ao panorama posto sob o paradigma da globalização. E isso significou a tentativa de expansão por novas plataformas, em especial, a TV por assinatura. Essa passagem não foi monolítica, dessa forma, vamos apresentar, no Capítulo II, como o poderio acumulado da Globo permitiu sair à frente da concorrência, a partir de mediação mais intensa com as demais plataformas, e como isso desaguou na constituição da Lei 12.485 .

\section{TV Por Assinatura}

Apenas em 1989, o governo brasileiro regulamentou as primeiras operações de TV por assinatura. Inicialmente, grupos de mídia nacional tinham maior participação na distribuição e na programação. No fim da década de 1990, a crise financeira que se abateu no país aprofundou o predomínio das empresas estrangeiras, bem como, o movimento de separação entre a atuação das operadoras de telecomunicações e programadores de conteúdo. Porém, essa reestruturação não foi acompanhada por alterações regulatórias na exploração das tecnologias, até que o serviço se estabiliza e passa a ter crescimento gradativo, sob maior relação com as demais plataformas do audiovisual. Nesse momento, a necessidade de unificar a legislação e de organizar novas regras se apresenta no Congresso Nacional em 2007. A decisão de impedir a presença das teles na exploração direta do conteúdo, seja por produção ou programação, ratifica a decisão metodológica do trabalho de não valorizar o destacar como grupo social distinto dos demais, e sim, incorporá-las como integrante na formação da programação da TV por assinatura.

facilitar o entendimento. A gênese, aqui, é caracterizar grupos que se formam em conexões com plataformas de distribuição e não de oposição entre si. 


\section{Estado}

Na Rede da "Lei da TV Paga", o Estado é um mediador com maior capacidade de retroalimentar a ação dos atores e actantes, isso, por sua vez, representa posição hierárquica nas relações de poder. O Estado e o corpo que o envolve não são neutros, trata-se de um mediador integrado por actantes e atores com interesses. Está envolto em relações de poder e dominação para a sociologia da tradução, que norteia o texto. Dessa forma, as movimentações do Estado passam, necessariamente, por identificação dos interesses e potencialidades dos parlamentares, membros do poder executivo e gestores nas definições regulatórias. Isso inclui os organismos multilaterais, o que não quer dizer um esvaziamento do caráter nacional. O Estado, por meio de suas atribuições regulatórias, também é peça chave na legitimação de distintas noções de liberdade e seus respectivos impactos no cotidiano dos indivíduos.

Descrever o processo em que o Estado desaguou na Lei 12.485/11 (BRASIL, 2011) passa por convergir metodologicamente os estudos nas políticas de cultura e de comunicação. Veremos, no Capítulo III, como a redemocratização é acompanhada por aprofundamento das relações entre as novas possibilidades técnicas e o projeto político econômico neoliberal. Foi, então, que as políticas do cinema foram extintas e recriadas na base da renúncia e de incentivos fiscais, e as de televisão foram divididas no paradoxo radiodifusão versus telecomunicações.

No anos 2000, os debates em torno da criação da Ancine representam reivindicações a partir do audiovisual nacional e independente, para unificar o escopo regulatório para um desenvolvimento integrado. Veremos como isso se intensificou em torno do Ministério da Cultura (MinC) nos governos Lula, e a correspondências às suas ações em algumas leis aprovadas no Congresso Nacional. Já, no retrospecto da tramitação da Lei 12.485, vamos destacar os depoimentos de parlamentares, consultores legislativos, relatórios e demais documentos indexados oficialmente.

\section{Arquitetura tecnológica}

As distinções no audiovisual entre plataformas tinham como uma das influências as diferentes tecnologias utilizadas. Ao longo do trabalho, vamos demonstrar como a digitalização passa a permitir uma uniformidade na tradução das informações captadas independentemente das plataformas, porém, continuam a existir distinções na administração da rede física de distribuição. 
A internet, nesse sentido, é uma tecnologia que tem seu fluxo binário estruturado na rede física, mas também é informacional, na medida em que também se conecta por meio de softwares, programas e aplicativos. O mesmo caminho é traçado na televisão, seja aberta ou fechada. A base dos sistemas físicos e informacionais se assemelha independentemente da plataforma e o que altera é a capacidade de restringir ou liberar o acesso ao conteúdo. Por isso, não se deve subestimar o estímulo ao gerenciamento privado no fluxo de dados por meio da TV por assinatura.

As transformações tecnológicas também abarcam a produção. Antes, o cinema utilizava processos químicos, e a televisão, eletrônicos, para associar a produção com a difusão. Atualmente, as câmeras digitais e as ilhas de edição são praticamente as mesmas, e também são mais baratas, facilitando empresas e coletivos independentes dos grandes players.

\section{Circulação do conteúdo}

Além das tecnologias, os símbolos também detém agência na constituição da Rede, nesse sentido, as obras audiovisuais são ponto de partida para descrever a atuação desse mediador. Vamos resgatar a formação e as distinções de conteúdo entre o cinema e televisão inicialmente. No caso do cinema, veremos como o ideal do cinema moderno se relacionou com o conteúdo, a partir dos conceitos de cinema de autor e do cinema independente, bem como um projeto industrial em aliança com o Estado e pretensões de alcance internacional. Ao mesmo tempo, outras expressões estéticas estiveram presentes como o "Cinema Marginal" e a valorização da comédia desde chanchadas.

Quanto à televisão, a influência do rádio, inicialmente, foi incrementada com o crescimento da publicidade e do marketing na produção. Veremos como as novelas e o popularesco dos programas de auditório e dos programas policiais foram importantes para aglutinar diversas classes sociais, todavia, a publicidade era destinada, majoritariamente, para parcela pequena da população.

$\mathrm{Na}$ década de 1990, as emissoras abertas continuavam a influenciar diretamente o hábito da população, e o seu modelo vertical/horizontal influenciou significativamente as demais plataformas do audiovisual, por meio dos profissionais, dos gêneros e dos formatos presentes na grade de programação: esportes, telejornalismo, novelas, séries e longas-metragens. Ainda assim, vamos resgatar as particularidades desenvolvidas na TV por assinatura, em especial, a valorização das séries e das minisséries, e os canais voltados para o público infantojuvenil. 
Ao longo da pesquisa, as obras que integram o conceito de conteúdo qualificado são enfatizadas, e o resultado final, por meio de categoria, formato ou gênero. Infelizmente, dentro dos limites da pesquisa, é inviável destrinçar as diversas etapas em cada produto. Algumas delas vão prevalecer na narrativa, a exemplo do consumo, da produção, da programação e da direção.

Vale retomar que, ao se relacionar com os indivíduos, o conteúdo, nas modalidades de TV por assinatura, ficou caracterizado pelo regime privado, propenso a planos de qualidade e mecanismos de combate à concentração, contudo, frágeis. As lógicas do consumo ainda são chave no processo para além da atuação das operadoras na distribuição, e também em como o público se relaciona com o conteúdo.

\subsection{A JUSTIFICAÇÃO DA AÇÃO}

Uma estrutura conceitual a ser introduzida para identificar a ação dos grupos sociais é a de Luc Boltanski (2000). Apesar de não ser filiado à TAR, ele é uma referência constante nos autores desses estudos. Sua teoria da ação preponderante é balizada no conceito de justiça e, por esse caminho, busca resgatar elos da teoria crítica. O modelo de justiça apresentado por Boltanski parte da reflexão de que existem vários eixos, e não apenas um eixo particulargeral. A fim de substanciar esses eixos, ele vai mergulhar na constituição do regime político particular: a relação das partes com o todo.

Para identificar as partes, Boltanski (2000) se baliza na justificação dos atores. O que eles argumentam ao sofrer uma opressão, ou buscar o reconhecimento para suas demandas? É nessa argumentação 'individual' que se encontram as competências, os dispositivos que fazem os atores agirem em prol de determinada causa. A linguagem não é exclusiva para entender as ações, soma-se aos objetos e aos dispositivos ancorados na justiça passíveis de atribuir reconhecimento dentro de uma sociedade determinada e sob historicidade. Num impasse, as pessoas se remetem ao senso de justiça para serem contempladas, ou não.

Por exemplo, como se articula a cultura nacional, enquanto uma causa defendida por determinados grupos para serem legitimados no Congresso Nacional? Como as tecnologias compõem a representação dos radiodifusores ou programadores de TV por assinatura?

Na justificação, os regimes de disputa são considerados por Boltanski (2000), inclusive o teor cínico de que se revestem. Mas, também existem os regimes de paz (ou amor) permeados pela incondicionalidade das relações. No regime de paz, não há culpa, nem necessida- 
de de remontar o passado. Não é um regime constante, mas representa o lado inviável da existência de ser permeada apenas pelo conflito. A teoria balizada na justificação vai atrás da contradição, do conflito e da paz, para encontrar as competências dos atores. Por isso, a dissertação vai buscar expor os argumentos dos grupos nos conflitos e consensos na constituição da rede.

Por fim, para Boltanski (2000), a ordem precisa ser mediada por um dispositivo dependente do Estado e de associações, inclusive que suplantem a "opinião pública", enquanto legitimadora das injustiças. O dispositivo da rede é a constituição da Lei 12.485/2011 (BRASIL, 2011).

\subsection{A CONVERGÊNCIA COMO DESPOLITIZAÇÃO DA TÉCNICA E 'DESTECNIFICAÇÃO' DA POLÍTICA}

A contextualização da relação entre técnica e política é fundamental para compreender os mediadores. Primeiro, vamos demonstrar as origens do paradigma da convergência e como ele passou a representar um discurso dos conglomerados de comunicação para justificar a adoção de padrões regulatórios nos diversos estados nacionais que viabilizassem os projetos de concentração lastreados em relações privadas entre tecnologias, grupos empresariais e cidadãos. Segundo, vamos situar rapidamente as peculiaridades na regulação das comunicações eletrônicas no Brasil, e sua correspondência aos interesses de conglomerados internacionais e do principal grupo de mídia nacional - as Organizações Globo.

Ao não separar a ação da técnica e da política, este trabalho afasta polos interpretativos: o primeiro é o determinismo tecnológico, segundo o qual, nossas relações socioculturais seriam definidas pela tecnologia, sendo caminho que tende a projetar uma noção de ruptura histórica a partir da digitalização; o segundo polo caminha para analisar a técnica como subserviente de relações socioculturais ulteriores, e, dessa maneira, tudo que estaria acontecendo seria repetição de processos sociais históricos. Escolher entre ambos se torna uma falsa questão para a Teoria do Ator-Rede, para a qual, as tecnologias são actantes e não representam um ente separado do ambiente comunicativo interpessoal. Mas, não apenas a TAR está preocupada com a segmentação na agência da política e técnica.

O geógrafo afro-brasileiro, Milton Santos, na sua obra mais conhecida, Por uma outra globalização: do pensamento único à consciência universal (2002) defende a estratégia de purificação entre política e técnica como pilar na produção da globalização perversa. Há ten- 
tativa de construir a história das técnicas de um lado, e a história da política de outro. Na sua leitura integrada sobre a história, Santos aponta que, no fim do século XX, um sistema de técnicas protagonizado pelas técnicas da informação ganhou proporção planetária, reconfigurando o comércio e a relação com o tempo, e submetendo as técnicas mais atrasadas, sob modus operandi político dos conglomerados transnacionais:

Antes, havia técnicas hegemônicas e não hegemônicas; hoje, as técnicas não
hegemônicas são hegemonizadas. Na verdade, porém, a técnica não pode ser
vista como um dado absoluto, mas como técnica já relativizada, isto é, tal
como usada pelo homem. As técnicas apenas se realizam, tornando-se histó-
ria, com a intermediação da política, isto é, da política das empresas e da po-
lítica dos Estados, conjunta ou separadamente... Essa unidade política do co-
mando funciona no interior das firmas, mas não há propriamente uma unida-
de de comando do mercado global. Cada empresa comanda as respectivas
operações dentro da sua respectiva topologia, isto é, do conjunto de lugares
da sua ação, enquanto a ação dos Estados e das instituições supranacionais
não basta para impor uma ordem global. Levando ao extremo esse raciocí-
nio, poder-se-ia dizer que o mercado global não existe como tal. (SANTOS,
2002, p. 13)

Entre os discursos presentes na globalização perversa, podemos identificar a recorrência da convergência tecnológica para proliferar o paradigma do determinismo tecnológico e seus efeitos causais nas relações sociais. Em partes, esses ditames se apropriam do pensamento de Ithiel de Sola Pool (1983), formulador inicial do conceito de convergência.

Sola participou da Escola de Chicago, quando foi liderada por Paul Lazarsfeld, e estudou os efeitos dos meios de comunicação de massa na opinião pública, em especial, nas sociedades dirigidas por regimes totalitários. O diálogo ponto a ponto do telefone lhe suscitou o caminho de pesquisa sobre os potenciais das novas tecnologias da época para a liberdade de expressão. Na obra Technologies of Freedom (POOL, 1983) ele retoma o papel do telefone e apresenta o conceito converge junto com a sistematização de uma agenda regulatória, em que os interesses comerciais devem ser compartilhados com os princípios da Primeira Emenda da Constituição dos EUA. Na época, Sola Pool estava preocupado com as possibilidades do cerceamento da livre expressão devido ao monopólio na infraestrutura da AT\&T.

O autor defende que não é mais possível falar dos meios de comunicação sem atentar para a integração entre suportes físicos e informacionais, também não é possível falar restritamente em conteúdos para plataformas segmentadas, ou mesmo, formular e adotar leis sem levar em conta tal integração. Esse é o fenômeno da convergência para ele.

Entretanto, a primeira questão que facilitou uma reapropriação conservadora por parte do conceito de Pool (1983) é a ideia de convergência elaborada a partir de problema semân- 
tico. ${ }^{5}$ Por mais que ele defenda a convergência como possibilidade de produção e compartilhamento de ideias e expressões artísticas, convergir significa o movimento de dois pontos para o mesmo lugar. E foi esse o discurso utilizado por grupos empresariais para tentar concentrar os negócios da informação e entretenimento por todo o planeta nos anos que seguiram. A segunda fragilidade na utopia da convergência de Itheil de Sola está na defesa de acabar com a escassez. O cabo representava para ele uma ruptura com a televisão tradicional. Enquanto o espectro no sistema analógico limitava o número de canais, o cabo permitia, para ele, uma abundância devido à integração com todas as faixas do espectro (GHz, UHF, MHz), fibra ótica, cabos coaxiais, radar e satélite.

Na publicação de 1983, Pool se depara com 30\% da população dos EUA utilizando o serviço para assistir mais canais de TV por assinatura. Ele viu com bons olhos a possibilidade de pagar para ter mais canais infantis, de alta cultura, esportivos ou pornográficos, desde que as empresas colocassem preços menos restritivos e ampliassem a diversidade dos conteúdos para outros grupos sociais, a fim de massificar por todo país novos hábitos para enfrentar um futuro próximo. Isso, porque a abundância a que ele se referia ia além, poderia viabilizar o common carriage (transporte público), e, assim, a infraestrutura do cabo poderia levar, até as residências, serviços explorados por diversas empresas como correio eletrônico, teleconferência, videotexto, e acesso a dados por meio do computador. Assim, o cabo, para ele, seria o preparativo para a década de 1990 quando os serviços telefônicos iriam implementar o mais sofisticado integrated services digital network (ISDN), qualificando os serviços existentes e incrementando novos. Ou seja, o cabo forçaria o monopólio telefônico a se curvar à integração democrática entre rede audiovisual e demais serviços comunicacionais na proliferação da digitalização.

$\mathrm{Na}$ época, Pool (1983) ele tentou oferecer alternativas para os interessados intervirem nos órgãos regulatórios, a fim de evitar o content control (controle do conteúdo). O objetivo era conciliar a liberdade de expressão com estímulo à competitividade empresarial, ou seja, o controlador da infraestrutura não controlaria a venda dos serviços. O tempo demonstrou que a produção da escassez não é um fenômeno natural da técnica, e, sim, relação entre a técnica e a política. Ainda assim, parece não ter sido em vão sua utopia. Um ano depois de seu livro ser lançado, em 1984, a AT\&T sofreu intervenção para quebrar o monopólio na telefonia. Nos anos 1990, seu pensamento continuou a se perpetuar quando a internet se alastrou. A

5 No dicionário Aurélio (1999), convergência é adjetivo do verbo convergir, que, por sua vez, significa: 1. Tender ou dirigir-se (para o mesmo ponto): 2. Ser o centro de; 3. Concorrer, afluir (ao mesmo ponto); voltarse; 4. Tender (para um mesmo fim). 
AT\&T reconstruiu seu monopólio, e as indústrias fonográficas e do cinema buscavam impedir a "pirataria".

Nesse contexto, também nos EUA, Lawrence Lessig (2005) buscou uma revisão do pensamento liberal para desenvolver o conceito de cultura livre. Lessig (2005) reafirma o copyright e necessidade dos mercados e artistas buscarem mecanismos de exploração econômica dos bens culturais, reafirma a necessidade de o cidadão ter acesso facilitado à cultura e também proteção às possibilidades criativas do ambiente digital. Todos esses fatores num mesmo ambiente, aparentemente, constituíam um impasse, mas resolve-se, por uma analogia utilizada por Lessig (2005): a quimera - um fenômeno em que dois DNAs diferentes coexistem no mesmo indivíduo. Dessa feita, ele tenta ponderar acertos e equívocos dos diversos lados da questão. Mais ainda, ele reafirma que o princípio da quimera conseguiu integrar o modelo liberal dos EUA para as indústrias culturais no século XX, sob impactos objetivos e positivos na democracia.

Lessig (2005) está interessado no crescimento da internet e os seus mecanismos de compartilhamento de dados, sem excluir outras mídias, numa visão sistêmica. A TV por assinatura nos EUA é retratada por ele pode deter práticas de "pirataria" na sua gênese, ainda na década de 1940. Ele retoma como foi a briga das operadoras de cabo com as emissoras de TV aberta para reproduzir o sinal para os assinantes, sem repassar nenhum recurso autoral. Ao final, a regulação estadunidense decidiu que era importante para o país estimular o cabo, enquanto possibilidade de ampliar ofertas de conteúdo ao cidadão, e, assim, utilizar o conteúdo da TV aberta.

Já na década de 1970, quando o serviço por assinatura se fortaleceu no país, Tim $\mathrm{Wu}$ (2012) defende que estaria em prática a primeira TV em mídia aberta dos EUA. Isso, porque o sistema de satélite estimulado por Ted Turner permitiu sair do controle da infraestrutura da AT\&T, tendo em vista que até então, qualquer transmissão por telefone ou radiodifusão, dependia dos troncos monopolistas da empresa. O negócio era simples, qualquer operadora local de cabo poderia comprar o conteúdo de Turner e repassar os custos ao consumidor conforme sua capilaridade.

Percebe-se, no resgate feito por Pool, Lessig e Wu, que a TV por assinatura está inserida, desde anos 1940, sob possibilidades de suposta convergência tecnológica. Ou seja, o cabo, desde início, permitia a integração entre serviços com distintas administrações no fluxo de informações. A diferença é que, a partir de determinado período histórico, mais serviços de telecomunicações puderam ser acoplados na mesma infraestrutura, e se tornaram iminentes os 
riscos de ampliar a concentração na cadeia produtiva, principalmente o controle da distribuição sobre a produção e programação de conteúdo.

A sinalização da fragilidade na conciliação entre os princípios liberais da propriedade privada com a liberdade de expressão torna a proposta da quimera de Lessig (2005) circunstancial frente aos interesses das grandes empresas. Tim Wu (2012) descreve esse processo como "O Ciclo", em que os grupos sociais que dominam novas tecnologias defendem princípios abertos e, aos poucos, passam por processo inevitável de concentração e fechamento por parte dos interesses empresariais, sob consequências na democracia:

Mas, numa indústria de informação, que comercializa um conteúdo expressivo, essas barreiras podem representar mais que uma restrição a aspirações comerciais: dependendo da forma como o meio de informação configura as comunicações numa sociedade, essas barreiras podem também coibir a livre expressão. (WU, 2012, p. 60)

Para finalizar, os autores se valem de suposto realismo para tratar como inexorável a presença de empresas com maior potencial de concentração e passam a defender que repassar aos cidadãos boas condições de consumo e às empresas um panorama competitivo na exploração tecnológica pode ser suficiente para corresponder aos anseios da liberdade. ${ }^{6}$

\subsection{A "CULTURA DO SILÊNCIO"}

Nesse panorama de conflitos entre a liberdade de expressão e a apropriação conservadora da convergência tecnológica por conglomerados, o consentimento ocorre pontualmente, ao estabelecer relações de consumo com um número limitado de cidadãos. Ainda assim, a noção liberal de liberdade não é a única na história, e seus efeitos também são dispersos conforme o tempo e o espaço em que suas conexões são construídas. ${ }^{7}$ No caso da rede em ques-

6 Entretanto, nem nos EUA, esse anseios são correspondidos. A concentração se espalhou na infraestrutura e no conteúdo a partir dos anos 1990, ao lado do discurso da convergência. E, atualmente, o debate está sintetizado na dificuldade para garantir a neutralidade da rede sob o discurso empresarial de que não há condições técnicas e econômicas para permitir o livre fluxo de dados nos meios físicos.

7 A metodologia histórica utilizada nesta dissertação tem como referência Gurminder Bhambra (2012). Em sua obra Rethinking Modernity: postcolonialism and the sociological imagination (2012), ela tenta reconstruir a modernidade, ao propor a lógica das conexões históricas. A autora irá defender a apreensão de modernidades múltiplas e plurais, e busca desenvolver uma provincialização das formulações etnocêntricas. Ela busca construir um discurso sociológico, desconstruindo a ideia de universalidade em prol da particularidade, e, assim, reatar as bases históricas. Para ela, as categorias tradicionais da sociologia não são universais, e, sim, eurocêntricas. Por isso, muitos estudos se tornam inadequados para dar conta da realidade com a qual lidamos. Ao mesmo tempo, ela busca repensar as categorias sem se perder no relativismo e no pós-modernismo. Apenas é preciso ter clareza das categorias que se justifiquem sem refletir de forma instantânea a modernidade eurocêntrica. 
tão, o tempo e espaço da sua constituição tem como característica a "cultura do silêncio". O conceito presente na obra de Paulo Feire foi retomado por Venício Lima na obra Comunicação e Cultura: as ideias de Paulo Freire (1981), para caracterizar o cunho autoritário na formação cultural da sociedade brasileira e seus reflexos nos sistemas de comunicação desde os meios impressos até os eletrônicos de massa, então, presentes.

$\mathrm{Na}$ busca por referências nas ciências políticas no projeto de emancipação libertária das práticas comunicativas, Venício Lima (2013), em outro momento da sua trajetória acadêmica, vai aprofundar duas concepções de liberdade que transitam na história, e, por meio delas, vai debater questões regulatórias nas comunicações:

Na perspectiva liberal, prevalece o caráter pré-político e privado da liberdade. Entende-se a liberdade como se ela pudesse ser desvinculada da política e como um direito formado exclusivamente na esfera privada. A versão mais conhecida dessa perspectiva é a que reduz a liberdade somente à ausência de interferência externa na ação do indivíduo, a chamada liberdade negativa.

Já na perspectiva republicana, prevalece a ideia de liberdade associada à vida ativa, ao livre-arbítrio, ao autogoverno, à participação na vida pública, na res publica. É daí que vem o significado original da palavra política, de polis, isto é, tudo que se refere à cidade, civil, público. (LIMA, 2013, p. 91)

As duas concepções, por sua vez, reconhecem a liberdade de expressão para a construção democrática, entretanto, trazem consigo duas formas distintas de o Estado atuar. A liberal defende a abstenção, pois o Estado é uma ameaça à liberdade. Na republicana, o Estado deve atuar em correspondência ao que for deliberado nos processo de participação pública (LIMA, 2013, p. 92). Em suma, Lima (2004) defende que prevalece a concepção liberal no Estado brasileiro, sob teor mais excludente e papel chave nas decisões das Organizações Globo. E, a partir da década de 1990, tal poderio é compartilhado com global players no que ele denomina nova política.

É neste panorama que a "Lei da TV Paga" é discutida e aprovada no Congresso Nacional. Por isso, veremos, ao longo da dissertação, como a nova política deixou suas credenciais no processo, em especial, no seu ponto de partida: o modelo de exploração que divide a atuação na infraestrutura e conteúdo, a fim de conformar grandes empresas. A convergência tecnológica, nesse contexto, passou a ser motivo para legitimar a atuação das empresa de telecomunicações, e a convergência no conteúdo, motivo para as Organizações Globo continuarem a ser o maior grupo de mídia nacional em condições de manter-se praticamente isolado num quadro de competição e associação predominante com as majors dos EUA. 


\subsection{A CIRCULAÇÃO TRANSMEDIADA}

Leis, tecnologias e grupos sociais têm importância para constituição do audiovisual, mas um quarto, e talvez óbvio, mediador traz consigo atores e actantes sem os quais a rede não faria sentido: o conteúdo em si. Nesse trabalho, ele é caracterizado a partir do conceito de circulação de Michel Callon (2005). Entre as estratégias de purificação das ciências modernas, está a separação da linguagem, ou símbolos, dos demais processos sociotécnicos em prol de ambiente comunicativo autorreferente e autoexplicativo. É certo que não se trata de uma novidade fazer essa interseção, há tradição de pesquisas que buscam coerência entre categorias como nação e identidade no processo de produção, inclusive na relação com o Estado, e o resultado final das obras audiovisuais. Coerência possível de ser abarcada em determinados exemplos, todavia, muito difícil, num quadro estético heterogêneo, com o que nos deparamos.

Circulação é, simultaneamente, um processo dinâmico que, no audiovisual, envolve consumo, distribuição, programação, produção, empacotamento, produção executiva, direção, edição, roteiro, montagem, marketing, fotografia, sonoplastia, ilustração, figuração e entre outros. Assim, são diversas agências. Aquilo que Karl Marx chama de valor de uso, Callon (2005) denomina como perfil dos produtos, constituído por heterogeneidade de agências no processo. O círculo valor de uso e valor de troca é reformado, antropologicamente, pela ideia de articulação e desarticulação - ou incorporação e desincorporação.

Dessa feita, esta compreensão é adotada para entender o fluxo em que os conteúdos analisados se constituem, sob a visão econômica performativa de Callon (2005), na qual direitos de propriedade intelectual têm papel crucial. Assim, as definições legais sobre o audiovisual se tornam mais abrangentes para definição dos direitos autorais objetivando abarcar as diferentes etapas da circulação, suas dimensões nacionais, capacidade de concentração, suportes físicos e até respectivos formatos e gêneros.

Esses movimentos em que as fronteiras são revistas costumam ser enquadrados sob o paradigma da convergência. Henry Jenkins (2009) é fonte recorrente para conceituar essa redefinição das fronteiras estéticas, políticas, técnicas e normativas como "cultura da convergência". Ele rejeita a primazia tecnológica e a unificação do acesso ao conteúdo num aparato - a "caixa preta" -, e passa a defender um fundo ulterior na sociedade, sintetizado pela noção de cultura, em que os cidadãos estão, de forma autônoma e empática, buscando outra relação com os meios: "a convergência representa uma transformação cultural, à medida que consumidores são incentivados a procurar novas informações e fazer conexões em meio a conteúdo de mídia dispersos" (Jenkins, 2009, p. 30). 
Deve-se destacar que essa não é a perspectiva sociológica desta dissertação, tampouco procuramos reproduzir a ideia de convergência, seja tecnológica ou cultural, o que interessa em Jenkins (2009) é sua busca por descrever os movimentos no conteúdo. A partir de então, pontes podem ser construídas, em especial, a sua utilização da noção de narrativa transmídia. Para Yvana Fechine e Alexandre Figuerôa (2010), essa transmediação utiliza estratégias de cross media para ressonância e retroalimentação, e remete "a toda produção de sentido fundada na reiteração e distribuição articulada de conteúdos em distintas plataformas tecnológicas (TV, cinema, internet, celular, etc.)" (FECHINE; FIGUERÔA, 2010, p. 284).

$\mathrm{Na}$ análise da rede em foco, veremos como a narrativa transmídia passou a ser apropriada e aprofundada por empresas que predominam no mercado de conteúdo. E, dessa forma, ao final, poderemos ratificar o porquê a tese da "cultura do silêncio" continua válida para a realidade a qual nos deparamos e construímos.

\subsection{MEIOS E TÉCNICAS DA PESQUISA}

O mapeamento da rede "Lei da TV Paga" precede a utilização de meios e técnicas de pesquisa adequada a proposta metodológica da Teoria Ator-Rede. As referências dos meios e técnicas foram subtraídas do trabalho de Carlos Gil (2010). Nesta dissertação o método observacional aparece como principal parâmetro na coleta de dados, e durante esse processo há tentativa de distanciar-se da observação participante. Buscou-se a observação sistemática, e, para isso, foi importante elaborar uma plano que identificou o ponto de vista dos grupos sociais, e indivíduos que influenciaram nas decisões da Lei 12.485/2011; bem como as categorias de questionamentos chave que podem se apresentar de forma explícita, ou por meio de pistas, resquícios, ou subjetividades das fontes.

Os documentos utilizados, além da Lei 12.485 foram reportagens, em especial da mídia especializada; atas, relatórios e estudos do Congresso Nacional relacionados à formulação da Lei. São registros classificados por Carlos Gil (2010) como cursivos. Assim, evita-se perder informações essenciais, bem como objetivas que facilitam o andamento da pesquisa.

Foram realizadas dez entrevistas gravadas, entre julho de 2014 e janeiro de 2015, a fim de obter sínteses e suprir lacunas da pesquisa bibliográfica e documental. Essas entrevistas tinham uma estruturação informal, focalizada por pautas. Esse caminho foi escolhido por relevar as categorias e permitir maior flexibilidade das perguntas com roteiro para cada indivíduo entrevistado, em interação simultânea, seja por vídeo chamada na internet ou presencial. 
Buscamos privilegiar entrevistados que detiveram algum tipo participação durante a elaboração da Lei 12.485/2011 e ao mesmo tempo representavam pluralidade de atores envolvidos nos grupos sociais destacados e, ou, no Estado. Apenas umas parte pequena de todo material coletado foi transcrito diretamente para o texto da dissertação, todavia, os diálogos foram fundamentais para descrever toda a rede.

Nas entrevistas amadureceu-se priorizar como primeira pergunta: "Como foi o processo de construção da Lei?”. Essa pergunta deixa em aberto ao entrevistado sua compreensão singular do que entende como processo, e consequentemente o permitia descrever ao máximo sua percepção e, assim, dispor à pesquisa pistas e informações para a constituição da rede que permitiram reafirmar e aprofundar a descrição dos mediadores. Ainda assim, a presença do pesquisador tem impacto nos relatos repassados. Desde dos diálogos por telefone ou e-mail para convencer os atores, inclusive ao destacar os propósitos da pesquisa.

O primeiro entrevistado foi o jornalista e pesquisador Samuel Possebon - Editor da Editora Converge, encarregada pelos diários eletrônicos Tela Viva News, Teletime News, TI Inside Online e Mobile Time. Possebon é responsável por publicação que resgata a história da TV por assinatura no país (POSSEBON, 2011), e acompanha sistematicamente o cenário envolto na rede. A escolha por obter por meio dele o primeiro relato se deu com o objetivo de ampliar a visão da rede e ao mesmo tempo conseguir informações mais detalhadas sobre o processo.

O segundo escolhido foi o prof. Dr. Marcos Dantas da Universidade Federal do Rio de Janeiro (UFRJ). A escolha por Dantas se deu por informações informais sobre sua participação na formulação da Lei 12.485/2011. O objetivo foi conseguir mapear a partir de então as pessoas envolvidas diretamente dentro e fora do Congresso Nacional, bem como selecionar temas que permearam os debates considerados chave. Dantas também relatou a importância ao sistematizar a cadeira produtiva no grupo de trabalho articulado pelo mandato do deputado federal Jorge Bittar (PT-RJ).

Alguns contatos foram encaminhados às instituições representadas. Nessas situações, encontrou-se maior dificuldade de selecionar um indicado com participação ativa na Lei, todavia, no geral, foram entrevistas valiosas por repassarem uma visão holística sobre a rede a partir do ponto de vista da instituição.

A Associação Brasileira de Radiodifusores (Abra) e Associação Brasileira das Emissoras de Rádio e Televisão (Abert) foram na fase inicial das entrevistas, e nesse momento a validade analítica dos mediadores escolhidos ainda estava imatura. Luis Roberto Antonik Diretor Geral da ABERT, permitiu expor o perfil do pensamento político dos radiodifusores 
quanto as propostas de reformas regulatórias no país. Ele defendeu que o país já detém um quantidade satisfatória de regras para a radiodifusão e há um panorama de competitividade, porém, segundo ele: "Tem uma turma da esquerda que tem discurso cansado que diz que aqui não tem pluralidade, tem monopólio, que é bom lá em Cuba" (ANTONIK, 2014, informação oral). A formação do diretor-geral a Abert passa por matemática, geografia e administração, é professor universitário na área de administração e finanças, e passagem na gestão de empresas públicas e privadas de telecomunicações. ${ }^{8}$ Durante a conversa enveredou para descrição do panorama tecnológico enfrentado pela televisão aberta a fim de continuar a predominar, em especial os aplicativos e aparelhos que permitem integração com plataformas móveis. Também apontou grande capacidade na infraestrutura da EBC, e a importância das suas finalidades educativas e culturais para o crescimento do país.

A preocupação com a arquitetura tecnológica na radiodifusão também esteve presente em Ronald Siqueira Barbosa - Consultor de Tecnologia ABRA. O escritório em Brasília divide o mesmo espaço com redação do jornal Metro1 e escritório executivo da Rede Bandeirantes, nesse local Barbosa fez um retrospecto envolvendo as tecnologias, as plataformas de distribuição e a relação com o público, e reafirmou sua formação em engenharia que o credenciou a participar do processos de testes na ação do modelo de televisão digital no Brasil e comissão voltada para radiodifusão terrestre na União Internacional de Telecomunicações. ${ }^{9}$

A Associação Brasileira das Produtoras Independente de Televisão (ABPITV) foi destacada nos materiais preliminares coletados, bem como primeiras entrevistas. Fundada em 1999, hoje detém mais de 400 associados no país, e realiza o RioContentMarket desde 2011 na cidade do Rio de Janeiro. A secretaria da Associação indicou o Diretor Executivo Mauro Garcia. Embora não tenha participado das negociações da Lei, relatou ter um histórico em emissoras públicas e durante a entrevista exercia a titularidade no Comitê Gestor do Fundo Setorial do Audiovisual (FSA), permitindo uma aproximação com tal instrumento chave na Lei $12.485 / 2011$.

A fim de descrever melhor os embates em torno das cotas no empacotamento ${ }^{10}$, Tereza Trautman - Diretora presidente do canal CineBrasilTV - foi a última entrevistada, já no mês de janeiro de 2015 Ela fez um longo histórico sobre os embates envolvendo empresas de telecomunicações, radiodifusão e cinema, e dificuldade da Anatel e CADE responderem às demandas relacionadas ao conteúdo enquanto a Ancine ainda era incipiente.

8 Disponível em: $<$ http://www.anatel.gov.br/Portal/exibirPortalNivelDois.do? acao $=$ carregaCombos\&codItemCanal $=1642$ \&pastaSelecionada $=2326 \% 23>$. Acesso em 10 fev. 2015.

9 Disponível em: $<$ http://www.set.org.br/curriculo.asp?id=412>. Acesso em: 10 fev. 2015.

10 Durante a seleção dos entrevistados também foi procurado um representante da Associação Brasileira dos Programadores de TV por Assinatura (ABPTA), porém a tentativa não foi exitosa. 
A escolha por Orlando Senna se deu por histórico envolvendo diversas etapas da circulação do audiovisual, e também participação significativa no Estado durante os governos Lula (2003-2010). Atualmente, Orlando é Coordenador da TAL- Televisão América Latina, uma cooperativa que agencia troca de conteúdos entre emissoras e programadores públicas e culturais. A ideia inicial era transformar a sua entrevista como um anexo do trabalho. Foram mais de duas horas de diálogo riquíssimo e coerente com a reconstrução histórica da rede, todavia, a riqueza da sua trajetória e as respectivas conexões com a rede fez com que passagens importantes fossem suprimidas no diálogo a fim de responder questões imprescindíveis para o Capítulo IV. O ideal era realizar mais uma entrevista, porém não tinha estrutura para continuar ou retornar ao Rio de Janeiro antes da conclusão.

$\mathrm{Na}$ Ancine, a proposta inicial era entrevistar o diretor-presidente, Manoel Rangel. Foram realizadas tentativas, sem respostas. Enquanto isso, o nome de Alexander (Alex) Patêz Galvão - Superintendente de Análise de Mercado da Ancine - se tornava mais recorrente entre os entrevistados. Nessa entrevista foi possível descrever melhor alguns conceitos da Lei 12.485/2011, e principalmente como a Ancine atuou no processo. A contribuição de Patêz se torna mais rica devido experiência acadêmica relacionada a economia do audiovisual e também passagem como gestor da Agência Nacional de Telecomunicações (Anatel) ${ }^{11}$.

No Congresso Nacional, os Consultores Legislativos da Câmara dos Deputados, Claudio Nazareno e José de Souza Paes Filho (Tito), foram fundamentais para repassar detalhes da tramitação a fim de identificar os interesses envolvidos e temas com maior densidade nos debates. Já o deputado federal Jorge Bittar (PT-RJ) tem formação em engenharia no Instituto Tecnológico da Aeronáutica (ITA), foi funcionário da Embratel, antes da privatização, por onde iniciou a atividade sindical. Bittar já detinha histórico de acompanhamento da Comissão de Ciência, Tecnologia, Comunicação e Informática (CCTCI) quando foi designado relator do Projeto de Lei 29/2007. Durante a entrevista foi possível descrever parte base da tramitação, e demonstrar como os diversos interesses em torno da Lei 12.485/2011 foram contemplados ou enfrentados para o prosseguimento.

11 Disponível em: $<$ http://buscatextual.cnpq.br/buscatextual/visualizacv.do? metodo=apresentar\&id=K4701847H9> $>$. Acesso em 25 jan. 2015. 


\section{CAPÍTULO II}

\section{DO MODERNO AO GLOBAL}

Descrever e analisar a constituição da rede audiovisual em questão é um exercício que tem como base a apuração bibliográfica do cinema e da televisão aberta. Durante o levantamento prévio para esta dissertação, foram identificadas, nas leituras realizadas, duas características comuns nas plataformas. A primeira característica assinalada está na recorrente leitura quanto à existência de fatos e processos que rompem com as formas antigas de produção. $\mathrm{O}$ segundo traço comum é o caráter nacional, nesse caso, quando o empresariado e outras formas de representação da sociedade civil têm seus interesses coadunados com o fortalecimento do Estado Nacional, independentemente da sua orientação política e econômica - ditatorial, democrática, ou neoliberal.

Abordar cinema e televisão aberta conjuntamente não é recorrente na literatura sobre ambos no Brasil até os anos 2000, sendo uma exceção os estudos de José Mario Ortiz Ramos (1995). Na obra Televisão, Publicidade e Cultura de Massa ele demarca dois processos de modernização ${ }^{12}$ no audiovisual nacional em conformidade com o estágio capitalista. No cinema, o marco, segundo o autor, são as crises da Vera Cruz e a expansão do mercado via atuação estatal da Embrafilme. Ainda para Ortiz, o fato fundador da modernidade na televisão é o erguimento da Globo como representante da estabilidade no sistema. Nesta dissertação, buscamos cartografar, na literatura, a presença desses dois traços e suas conexões históricas com a "Lei da TV Paga" considerando a interação com a tecnologia, circulação do conteúdo, grupos sociais e Estado, no diálogo entre cinema e televisão.

Constatamos, nas leituras levantadas ao decorrer do capítulo, que a absorção do cinema pela televisão aberta sempre foi recorrente, principalmente na ocupação da grade de pro-

12 Para Habermas (2002), somente nos anos 1950 o conceito de modernização se apresenta como releitura de Max Weber. A partir de então, desvincula-se de certo etnocentrismo ocidental, e passa a ser aplicado a qualquer situação, desde que se caracterize por processos aproximados de natureza econômica, efetivação do poder, obtenção de direitos e redesenho cultural. Todavia, não é uma ruptura com a ideia de modernidade, enquanto busca de uma "história universal", ou melhor, porque uma interligação entre 'cultura e sociedade' não se espraiou de forma semelhante em todo mundo. 
gramação com conteúdo internacional. O impasse era maior na interação entre o cinema nacional e a televisão. Quanto à televisão por assinatura, sua fase inicial também passa por participação chave de grupos nacionais. Mas, desde cedo, há predomínio do conteúdo estrangeiro, e, paulatinamente, isso se complementa com grupos socioeconômicos na exploração de todas as atividades da cadeia sistematizada na Lei 12.485/2011. Isso não significa o fim do Estado Nacional, e, sim, uma configuração política e cultural lastreada na lógica do serviço privado e na força das empresas transnacionais.

Antes de antecipar os acontecimentos, vale ressaltar que a abordagem cronológica a seguir não representa uma linha evolutiva na história, o que marca o levantamento deste capítulo é a dita modernidade e a globalização no cinema e na televisão, que, por sua vez, não se extinguiram. Vamos identificar as quatro interações mencionadas, em seus fluxos internos e externos, apontando seus conflitos e contradições.

\section{1 O CINEMA MODERNO}

Os anos 1950 são marco inicial do cinema moderno para Ismail Xavier (2001), que, em sua obra, busca desmitificar uma literatura sobre o setor, na qual o moderno é destacado

para substanciar apenas o elemento artístico dos filmes. É indiscutível a influência da estética nos discursos acadêmicos, políticos ou empresariais dessa literatura, porém é igualmente possível analisar que o enquadramento moderno também tem efeito reverso: política e economia influenciando a estética. $\mathrm{O}$ debate sobre o cinema brasileiro moderno também vem acompanhado de amadurecimento dos produtores sobre o papel determinante do Estado, bem como de uma revisão da percepção sobre a produção: desde a mentalidade sobre a organização, que passa a ser não apenas mercantil, mas, principalmente, industrial; até a compreensão que a produção em geral envolve a distribuição e consumo.

Dessa forma, na década de 1950, as relações entre o Estado e o cinema são rediscutidas num panorama de falência dos estúdios nacionais, dotados de investimento e estrutura que almejavam ter a pujança dos grandes estúdios hollywoodianos. Mas, não foi a derrocada de uma indústria nacional, simplesmente por não existir o modelo industrial tido como ideal. Havia efetivamente produções nacionais com reconhecimento do público e particularidade estética, em especial as chanchadas; público passando pelas catracas em números expressivos ao ser comparado com o mercado internacional, e também movimentação financeira no setor. 
Mas, a indústria, num sentido ideal, que envolve um grau de organização e desenvolvimento de toda cadeia nos diversos degraus culturais e produtivos, não era reconhecida. ${ }^{13}$

Era preciso inaugurar um novo tempo no cinema brasileiro, e o primeiro passo foi ocultar e excluir as referências até então postas. As chanchadas, segundo Xavier (2001), são símbolos desse traço moderno, pois foram negligenciadas pela crítica do seu período, mas obtiveram grandes públicos e lançaram vedetes e diretores que têm, paulatinamente, a importância reconhecida: Grande Otelo, Oscarito, Dercy Gonçalves e, até mesmo, Anselmo Duarte, ator e diretor do premiado O Pagador de Promessas (1961). ${ }^{14}$ Também é negligenciada a importância de filmes como $O$ Cangaceiro (1953) da Vera Cruz, que atingiu grandes bilheterias em todo mundo, mas representou o fracasso nacional, pois os direitos de exploração ficaram a cargo dos distribuidores estrangeiros.

Sem dinheiro e reconhecimento da crítica, aos poucos correntes começaram a se aglutinar e pensar de forma mais sistematizada o desenvolvimento do setor. ${ }^{15} \mathrm{O}$ que nos interessa, aqui, é demarcar a influência de atores no setor sem uma subserviência nas suas movimentações ao mercado, nem ao Estado. Na maioria são diretores, mas também somam-se críticos, roteiristas, produtores e outros integrantes do processo produtivo legitimados por atributos intelectuais na atuação política (XAVIER, 2011).

Glauber Rocha é o maior representante deste tipo de intelectual militante. Na obra $R e$ visão crítica do cinema brasileiro (ROCHA, 2003), são demarcadas as suas posições, no início dos anos 1960 quanto ao desenvolvimento do audiovisual nacional. Polissêmico e, por vezes, verborrágico, Glauber é dificilmente enquadrável numa corrente ideológica. Ao longo da trajetória muda de posição sem se perder no contexto, diverge de si sem contradizer seus interesses. Ele aponta problemas como a ineficiência nas atribuições dos críticos, falta de formação dos profissionais, salários ruins, vínculo subserviente com as distribuidoras estrangeiras e ausência de pensamento articulado entre a categoria. E deixa dois legados no setor: os conceitos de cinema independente e de cinema de autor.

13 O sistema adotado no Brasil foi o de package-unit, em que a realização da obra determina o processo, pois o "produtor mobiliza as condições de trabalho da indústria, mas não fica limitado ao estúdio, organizando um arranjo para cada filmes" (RAMOS, 1995, p. 19). Este modelo é parecido com o independente estadunidense, ou seja, apenas um modelo numa indústria, que, teoricamente, deveria envolver outros

14 Escolhido melhor filme do júri no Festival Cannes em 1962, "O Pagador de Promessas" não se enquadra no Cinema Novo, Outra curiosidade é que a ideia inicial era que a história se tornasse uma minissérie para televisão.

15 Anita Simis (2009) irá refutar um nível tão elevado de distinções entre essas correntes ao levar em consideração as reivindicações das políticas estatais, e, até mesmo, as associações com o empresariado estrangeiro. Suas distinções são demarcadas por questões circunstanciais, em especial, a geográfica entre Rio de Janeiro e São Paulo. Porém, vale mencionar também que os ciclos regionais também envolvem estados como Bahia e Minas Gerais. 
O primeiro permanece ao relacionar a produção à atuação do Estado, a fim de torná-la autônoma aos interesses estrangeiros, estando, portanto, vinculado a um projeto civilizatório de nação. O segundo foi enfraquecido no ideal nacional e se aproxima de uma capacidade emancipatória da arte industrial desde que esteja em contraposição ao comercial e também à tradição. O cinema de autor é defendido enquanto transhistórico, revolucionário, não determinado pela tecnologia, vinculado à superestrutura e também influenciável por mentalidades individuais.

Os livros de Anita Simis (2009) e José Mário Ortiz (1983) resgatam como a constituição desse segmento na sociedade se relacionou com as políticas estatais. Ainda nos anos 1950, foram realizados os primeiros Congressos de Cinema (1952 e 1953), e, posteriormente, as Comissões de Cinema no governo Kubitschek (1956-1961) vão buscar alçar o setor à categoria de grandes preocupações nacionais ao lado do petróleo por meio de "soluções que permitissem a instauração de um cinema em bases industriais" (ORTIZ, p. 16). O debate foi fortemente influenciado pelo processo paulista, já que, desde 1955, inicialmente com a prefeitura e depois com o governo do estado, as formulações sobre a participação do Estado no cinema avançavam com maior organização e celeridade.

Simis (2009) remonta os relatórios da Comissão Municipal de Cinema que tentavam desvendar porque um país com tamanha bilheteria detinha uma produção baixa em comparativos internacionais, em especial, com México e Argentina. A autora aponta que era improcedente a solicitação para aumentar os repasses na produção, pois já eram relativamente altos em relação ao que era praticado em outros países. Quanto ao preço dos ingressos, ela indica ser uma questão não determinante, já que não afetaria o produto nacional e poderia, até, causar efeito reverso. A pergunta crucial da época colocada por Simis (2009) é: por que o cinema estadunidense tinha, no Brasil, um dos principais mercados de exportação, sob crescimento exponencial no pós-guerra, e, além de ocupar espaço nas telas, compunha um cenário lucrativo para exibidores e distribuidores nacionais?

Um elemento ressaltado pela autora é que os filmes dos EUA não eram vendidos separadamente, e, sim, por lotes com dezenas de obras. Ao exibidor era mais vantajoso, mesmo que a maioria fosse de filmes fora do mainstream, classificados como tipo C por serem pensados para a TV ou mesmo para exibição restrita a subúrbios nos EUA. Outro ponto chave é que as remessas de recursos arrecadados com os alugueis das cópias eram enviados com taxas baixas, favorecidas por um regime cambial de desvalorização da moeda nacional.

Simis destaca que o cinema estadunidense teve suas bases fincadas no mercado interno e, paulatinamente, transformou o mercado externo em essencial, ao ponto de ser uma das mai- 
ores indústrias dos EUA, ao lado do aço, petróleo e cigarros. Mais ainda, o cinema era porta de saída para comercialização de outros produtos manufaturados e enfrentava políticas protecionistas na Europa, a exemplo de quotas e subsídios. Fica, então, posto que o mercado audiovisual é intrínseco a questões geopolíticas e mercantis em nível internacional, principalmente dos EUA.

Percebem-se, aqui, questões que se perpetuam na rede audiovisual, já que o conteúdo nacional precisa de estímulo e reserva, a fim de concorrer com o volume de origem estrangeira, somados às condições cambiais equilibradas. Já a dinâmica da circulação não se restringe à capacidade de desenvolver narrativas mais convincentes, muito menos, utilizar melhor luz, som ou interpretação dos atores, posto ser o reconhecimento do público fundamental. Também compõem o jogo na movimentação dos cineastas a arquitetura tecnológica com a reprodução em laboratórios das cópias, a propriedade das câmeras e demais equipamentos de produção e exibição.

Voltemos à narrativa, a fim de aprofundar esses mediadores. Num cenário desfavorável, um conjunto de obras expressivas da cinematografia nacional continuava a produzir e, em alguns casos, a render financeiramente às margens do sistema exibidor. "[A falta de espaço no mercado] forçava a produção a realizar-se em bases artesanais, rápida, composta de equipes reduzidas e feita preferencialmente fora dos estúdios - em suma, a produção de baixos orçamentos a que o Cinema Novo se propôs por opção, em contraposição ao cinema industrial" (SIMIS, 2009, p. 19).

O impulso também tinha um elemento tecnológico. O que era antes receio da influência dos equipamentos norte-americanos torna-se elemento democratizador, conforme defende Cacá Diegues (1989):

Nos anos 60, a tecnologia cinematográfica era democratizadora. Nesta época, a Kodak começou a produzir os filmes Tri-X, que tinham sensibilidade maior, que permitiam que você filmasse sem luz artificial. Apareceu o Arriflex, e você podia começar a fazer filme com a câmara na mão. O Nagra foi inventando, e o som passou a ser portátil. Eu diria que sem o Tri-F, a Arrifex e o Nagra o Cinema Novo não teria existido.

O movimento Cinema Novo ${ }^{16}$ deu mais credibilidade aos profissionais e também mantinha o ritmo organizativo em nível social. ${ }^{17}$ Nessa toada, é criado o Grupo de Estudos da In-

16 Rio 40 Graus (1955) dirigido por Nelson Pereira dos Santos é considerado o percursor do Cinema Novo.

17 Coutinho (2011 p. 32) defende que a modernização capitalista no Brasil é acompanhada por processos de diferenciação e desenvolvimento no mercado cultural, inclusive a possibilidade de os produtores sobreviverem com autonomia às empresas: "O velho intelectual elitista, prestigiado por possuir cultura converte-se cada vez mais em trabalhador assalariado. Experimenta agora a necessidade de se organizar, como qualquer outro grupo social, para lutar por seus interesses específicos, entre os quais não se situa 
dústria Cinematográfica (GEIC) no governo Juscelino Kubitschek (1958-1961), porém sem força expressiva institucional, passando apenas a reproduzir sem efetivar demandas já sistematizadas. No legislativo, a Lei 3.244/1957 para mudança cambial foi alvo de intensos debates num panorama do governo JK em que o desenvolvimento era dividido entre os setores com abertura ao capital internacional, e outros em que prevalecia a base nacional. Ao fim, o forte lobby fez prevalecer um regime de taxação favorável a Hollywood. ${ }^{18}$

No governo Jânio (1961-1964), a política é tocada por meio do Grupo Executivo da Indústria Cinematográfica (GEICINE) e obtém consenso entre as correntes, ao ampliar as quotas de tela e também a definição do que seria "filme brasileiro". As divergências vão se dar no processo de aproximação com o setor distribuidor-exibidor. A primeira proposta significativa foi a de "distribuição compulsória" e buscava uma proporção de um filme nacional para cada dez estrangeiros nas programadoras, sob a perspectiva de que o empresariado estrangeiro fosse investir na produção nacional para suprir o vácuo de um décimo nas salas de exibição. A segunda proposta foi a remessa de lucro dos filmes estrangeiros ser taxada em $40 \%$ e que o dinheiro arrecadado fosse repassado para fomento do conteúdo nacional. Nenhuma das duas deu certo.

As tentativas e articulações para executar uma política eficiente no desenvolvimento do cinema nacional se esvaiam, mas o debate permanecia. No Legislativo, uma Comissão Parlamentar de Inquérito (CPI) investigou a situação da atividade cinematográfica nacional e estrangeira entre 1963 e 1964, todavia, o projeto de Lei para implementação do Instituto Nacional de Cinema (INC) estava engavetado.

Somente com a ditadura, o órgão foi criado (1966), objetivando centralizar e organizar a administração da indústria cinematográfica. No momento de sua criação, ainda era possível alguma liberdade para auferir críticas ao governo e, assim, o INC foi acompanhado por receio de que os militares neutralizassem a liberdade criativa, ou mesmo estivesse em subserviência aos interesses dos EUA. Também era o momento de consolidação do Cinema Novo. Terra em Transe (1967) dirigido por Glauber Rocha voltou a levar o país à posição de destaque em Cannes, e, dessa vez, repercutia no cenário cultural, influenciando outros movimentos, em especial a Tropicália. Mas, o vigor vai se esmorecendo à medida que a ditadura entra no período

apenas a melhoria por condições de trabalho; e, entre essas últimas, ocupa lugar de destaque a sua autonomia enquanto criador".

18 Não por acaso, inclusive, via embaixador brasileiro em Washington, nove companhias - Metro-GoldwinMayer, Columbia, Universal, Disney, Warner, Fox, Allied Artists, Paramount e United Artists - formaram uma associação que pressionou diversos governos, entre os quais, o brasileiro, a fim de evitar mecanismos protecionistas (SIMIS, 2009, p. 208). 
mais autoritário, e também que diferentes matrizes ideológicas são contempladas por ações do $\mathrm{INC}$, desde que tivessem potencial mercadológico.

O INC perdurou até 1975 e, por meio de leis e decretos, foi destinado a ampliar as quotas do cinema nacional, estimular o desenvolvimento de laboratórios de impressão, modernizar a contagem nas bilheterias e reestruturar a lei de remessas de lucros para conseguir destinar a arrecadação ao fomento do produto local. Já, em 1969, o INC teve a companhia da Embrafilme. Inicialmente voltada para exportar filmes brasileiros, a Embrafilme foi constituída como uma empresa (sociedade anônima) e contava com recursos arrecadados na movimentação dos filmes estrangeiros.

Tal quadro nas políticas, somado ao aumento da repressão, foi acompanhado por aumento na participação de teor técnico-propositivo no setor. No I Congresso da Indústria Cinematográfica (1972), governo e membros da cadeia produtiva tiveram espaço para debate. Técnicos passaram a colocar problemas nas relações de trabalho e, principalmente com distribuidores e exibidores.

\subsubsection{Política internacional dos governos militares a Sarney}

No percurso da década 1970, uma agenda internacional com a articulação dos países "não alinhados" do "Sul” conseguiu superar as amarras dos embates da Guerra Fria, estimulando novas formulações de desenvolvimento e questionamentos sobre a distribuição de riqueza de forma desigual entre os povos, por meio da Nova Ordem Econômica Internacional (NOIE). Nesse contexto, a UNESCO serve de guarita para formulações entre cultura e desenvolvimento, que vinham se avolumando desde Tratado dos Direitos Econômicos, Sociais e Culturais (1966).

A autodeterminação nacional aparece na primeira parte da Declaração como pressuposto a ser seguido pelas resoluções. A descolonização afro-asiática e a ampliação da participação política na América Latina fizeram com que os dois blocos hegemônicos buscassem estratégias para seduzir as elites e classes populares pelo globo. A autonomia dos países se torna balizadora dos documentos. No caso brasileiro, há de se levar em conta como o país conduzia as relações exteriores a partir da revisão historiográfica de Clodoaldo Bueno (2011). Ele descreve que os governos militares, apesar das nuances, terminam com a estratégia de fortalecer o conflito Norte-Sul, o que foi continuado por José Sarney (1985-1990). No caso do setor cultural, em 1975, o Plano Nacional de Cultura (PNC) é assentado na lógica do desenvolvimento 
subsidiado pela Unesco e também se relaciona com a ideia de integração-identidade nacional a ser preservada num contexto de internacionalização da cultura. Ortiz (1983) confirma essa relação, ao identificar um nível de associação ao panorama internacional nas políticas como meio de superação do atraso.

Durante os debates do Plano Nacional de Cultura (PNC), Ortiz (1983) identifica em Gustavo Dahl, que viria a ser o primeiro presidente da Ancine, uma visão articulada à perspectiva de modernização, por acreditar que os meios fariam um papel de junção entre a função de entretenimento, a função social e a capacidade de propagar a identidade de um povo. Dahl (1975) defendia uma junção entre Estado e cultura, enquanto Leon Hirszman (1975) ${ }^{19}$ defendia uma posição que relacionava cultura popular e nacional, e, ao mesmo tempo, uma proposta de compactuação entre as diversas tendências no cinema. Nessa conjuntura política, até mesmo Glauber Rocha parte em defesa da Embrafilme, com a justificativa de que enfrentava as multinacionais (ORTIZ, 1983).

Vale mencionar que um grupo oriundo do Cinema Novo, formado por membros da Associação Brasileira de Cineastas (ABRACI), criou uma cooperativa devido ao predomínio de alguns cineastas na capitalização dos recursos da Embrafilme, em especial, Luiz Carlos Barreto. ${ }^{20}$ Nesse período, também se retoma o debate da produção independente, dessa vez, preocupada com fontes de sustentabilidade fora do Estado, inclusive em diálogo com o Cinema Marginal. Com uma proposta mais radical, entre 1968 e 1973, o Cinema Marginal, ou Cinema do Lixo, emerge com a preocupação estética ligada ao subdesenvolvimento e se afasta do viés modernizante-industrial. O Cinema Marginal também se afasta do Estado, e, até mesmo, de uma aliança com o grande capital, e busca bancar sua produção com recursos de pequenos e médios comerciantes e industriais. O teor transgressor do conteúdo é alvo de dura pressão política da ditadura e acelera o fim do movimento.

Outra vertente, entre os anos 1960 e 1970, fora dos debates em relação ao Estado e também de uma perspectiva industrial-comercial está relacionada a uma inovação tecnológica: a câmara super-8. Surgem novos diretores fora do "cinemão", e, até mesmo, artistas de outras linguagens como Hélio Oiticica e Torquato Neto se aventuram a produzir conteúdo audiovisual sem pretensões de chegar às salas de cinema ou à televisão. ${ }^{21}$

19 Hirszman (1937-1987) foi um dos fundadores dos Centros de Cultura Popular (CPC) da União Nacional dos Estudantes. Dirigiu um dos episódios de Cinco vezes Favela e filmes como São Bernardo (1971) adaptação do romance homônimo de Graciliano Ramos - e Eles Não Usam Black Tie (1981).

20 Luiz Carlos Barreto, conhecido como "Barretão", começou a carreira como repórter da revista Cruzeiro, foi coautor do roteiro e coprodutor do filme Assalto ao Trem Pagador (FARIAS, Roberto. 1962)). Também foi diretor de fotografia de longas como Vidas Secas (SANTOS, Nelson, 1963) e Terra em Transe (ROCHA, Glauber, 1967).

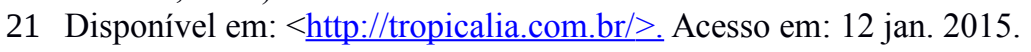


Mas, não foi essa a perspectiva na consolidação da Embrafilme nos anos 1970, e, sim, a consolidação das produções com retorno financeiro dentro de um padrão técnico estético. Inicialmente, alguns diretores premiados internacionalmente foram contemplados com parcerias, porém, aos poucos apenas aqueles com capacidade de dialogar com os distribuidores e ter aceitação imediata do público passaram a ser beneficiados pelo modelo de financiamento da empresa. Desde 1975, sem o INC, a Embrafilme assume os papéis de financiar, coproduzir, distribuir e preservar material audiovisual, e vê seu capital ser aumentado em mais de treze vezes, oriundo de fontes de receitas das atividades exercidas, mais a bilheteria e impostos sobre remessas de lucro. Com tal robustez, a empresa busca focalizar até mesmo as produções regionais, ao abrir sedes em todas as regiões do país (ORTIZ, 1983).

A década de 1970 inaugurou a época mais pujante do cinema nacional em termos de participação nas bilheterias. Entre os anos 1978 e 1984, Lia Bahia (2012) sistematiza que o market share (participação em bilheteria) do conteúdo brasileiro ficou na casa dos $30 \%$. A cota na tela também avançou, batendo os 140 dias por sala entre 1979 e 1981 (BAHIA, 2000 apud, AMÂNCIO, 2000, p. 57). Foi o período de filmes como Dona Flor e Seus dois maridos (1976), que alcançou 10,7 milhões de espectadores, dirigido e produzido pela família Barreto. Já as diversas versões protagonizadas pelos Os Trapalhões alcançaram cerca de 90 milhões de pessoas entre os anos 1970 e 1980, e o grupo chegou a abrir uma produtora própria, a Renato Aragão Produções Artísticas. A linguagem circense do quarteto segue por influências escamoteadas pelos discursos das vanguardas europeias, tendo as chanchadas e Amâncio Mazzaropi como referências estéticas.

Iniciado no cinema na Vera Cruz, Mazzaropi percebeu a fragilidade do modelo e partiu para criar sua própria empresa, a Produções Amácio Mazzaropi (PAM Filmes), com a primeira das 24 obras lançada em 1958, O chofer da praça. A estimativa é de que os 32 filmes em que Mazzaropi atuou tenham alcançado 200 milhões de espectadores ao longo de sua carreira. ${ }^{22}$ Sua fórmula começava ao testar piadas com a atividade circense em cidades do interior de São Paulo, depois, escrevia o roteiro, dirigia e atuava, por vezes, como mais de um personagem em cada filme. As filmagens se davam num estúdio construído na cidade de Taubaté (SP), que, hoje, acolhe um museu em sua homenagem. ${ }^{23}$ Em seguida, negociava diretamente com os exibidores, e, para não ser enganado, empregava diretamente fiscais e fiscais de fiscais nas bilheterias.

22 MAZZAROPI. Celso Sabadin. 2014.

23 Disponível em: < http://www.museumazzaropi.org.br/>. Acesso em: 12 jan. 2015 
Assim, Mazzaropi construiu uma fortuna com imóveis, equipamentos, terras e carros, a maioria leiloado após sua morte em 1981. Trata-se de um patrimônio formado a partir da releitura da figura do caipira no processo de passagem do país rural para urbano. Nessa atmosfera, o caipira de Mazzaropi não é o Jeca Tatu de Monteiro Lobato - símbolo da inexpressividade e do atraso - e, sim, aquele que conseguiu reconfigurar seu repertório de vida para sobrevivência e, por vezes, protagonismo nos círculos sociais em transformação.

A dinâmica do cinema nacional também foi influenciada pelo movimento Cinema Boca do Lixo, surgido na passagem para os anos 1980, basicamente, em São Paulo. O movimento é fundamental para criar a polarização entre "cineminha" versus "cinemão" que se perpetua mesmo que silenciosamente. O "cinemão" era formado por diretores e produtores como Luiz Carlos Barreto e Cacá Diegues, respaldado pela Embrafilme e detentor de parcela majoritária das boas bilheterias do cinema nacional da época. Enquanto o "cineminha" se desenvolvia por outras fontes de recursos, detinha pouco reconhecimento estético e se associava até a produções discriminadas, como as pornochanchadas (RAMOS, 1995).

Aos poucos, o Boca do Lixo passou a ser legitimado pela Embrafilme ao lado de obras como as do grupo humorístico "Os Trapalhões", que rompia as barreiras entre cinema e TV, mas eram desconsiderados pela crítica cinematográfica. O fato é que a década de 1980 ratifica a TV aberta como principal plataforma de difusão e acesso ao conteúdo cinematográfíco no país, mais ainda, o modelo comercial adotado se mostra autossustentável economicamente, aliado à publicidade, embora seja acompanhado por uma lógica de concentração desfavorável à democracia e tenha, na sua origem, diversos mecanismos de subsídios e investimento estatal, além da própria natureza concessionária.

\subsubsection{Cinema e globalização}

No fim da década de 1980, há um ruído entre o que era produzido com recursos da Embrafilme e referenciado pelo público, e o que os intelectuais do cinema defendiam e legitimavam para as elites políticas e para as políticas de Estado a partir da década de $1950 .{ }^{24}$ No geral, há deslegitimação em relação a Embrafilme, e, ao mesmo tempo, surgem denúncias de corrupção em relação à Lei Sarney, a qual viabilizava incentivos fiscais àqueles que financias-

24 Esse descompasso não é completamente pioneiro, vale lembrar que O Cangaceiro (1953), dirigido por Lima Barreto, foi a primeira obra da Vera Cruz e obteve números expressivos de bilheteria e público em nível internacional. Curiosamente, os direitos autorais foram comprados pela Columbia Pictures, que, por sua vez, ficou com o lucro, enquanto isso, Lima Barreto, Vera Cruz e o cinema brasileiro quebraram, ainda assim, a obra é secundarizada na historiografia do cinema nacional. 
sem filmes nacionais. Enfim, Melina Marson (2010) ressalta que a Embrafilme, quando fechada por Collor em 1990, era fruto de um casamento entre política neoliberal e desarticulação do segmento cinematográfico. Ela resgata também dois fatores que influenciaram a crise da empresa no fim dos anos 1980: a própria crise financeira que se abateu no país, somada à renovação tecnológica e comercial de Hollywood nos high concept movies.

O fim da Embrafilme também veio acompanhado por uma série de medidas que pôs fim: à cota de tela, aos incentivos aos festivais, ao desenvolvimento de laboratórios e participação do segmento nas decisões sobre políticas públicas. ${ }^{25}$ Para piorar, o impacto se estendeu por todo setor cultural ao transformar o Ministério da Cultura em Secretaria. Um período de crise mais profunda do que a da década de 1950 instaurou-se no início dos anos 1990. Marson (2006) aponta a falta de uma perspectiva coletiva e nacional, o aprisionamento ao "cinema de autor", em detrimento da visão mais industrial do setor Era o momento de refazer as políticas, e repetiu-se a história de medidas paliativas ou efetuadas na base da tentativa e erro.

Ainda no governo Collor (1990-1992), remontam-se institucionalmente os debates com uma Comissão Nacional de Cinema formada por membros do governo e associações de classe. O resultado inicial é a abertura de linhas de financiamento com o BNDES e a restauração da cota na tela, porém esses movimentos não atingem o resultado esperado (MARSON, 2006). Então, Sérgio Paulo Rouanet assume a Secretaria de Cultura, dialoga com a classe artística e cria o Programa Nacional de Apoio à Cultura (PronaC), conhecido como Lei Rouanet (BRASIL, 1991), que perpetua sua lógica até os dias atuais.

O Programa é dividido em três linhas de ações ainda presentes: (i) Patrocínio direto do Estado via Fundo Nacional de Cultura (FNC); (ii) Venda de cotas de patrocínio para financiar espetáculos, publicações e equipamentos por meio dos Fundos de Investimentos Culturais e Artísticos (FICART); (iii) Patrocínio direto dedutível do imposto de renda, por meio do Incentivo a Projetos Culturais. Dessa feita, as empresas poderiam se tornar não apenas apoiadoras do projeto, mas, também, integrar os direitos patrimoniais nas etapas de comercialização.

As medidas não agradaram por completo o setor cinematográfico. $\mathrm{O}$ clima era de pessimismo com a falta de expressão em quantidade e qualidade das películas lançadas. Por isso, houve pressão para aprofundar uma política específica, porém presas à ilusão liberal ao defender a associação com os conglomerados internacionais ou a ideia de relaxar as medidas protecionistas (MARSON, 2006).

25 A Fundação do Cinema Brasileira e Conselho Nacional de Cinema também foram fechados no governo Collor. 
Antes do governo Collor terminar em impeachment, instituíram-se leis e decretos que regulamentaram a cota de tela, reserva a laboratórios nacionais, definição do que é o filme nacional, viabilização da conversão da dívida externa no fomento por meio do estímulo a estrangeiros realizarem filmes no país, e, por fim, liberação de recursos da União pertencentes à Embrafilme para fomentar produção via Ficart, que poderia pagar até $80 \%$ das obras. A TV continuou diretamente de fora, mas chegou-se ao mínimo consenso de que era necessário reerguer a política para o setor. Essas políticas se mantiveram até que, no governo Itamar Franco (1992-1994), concluiu-se a base do Cinema da Retomada. Primeiramente, foram liberados os recursos da Embrafilme, transformados no Prêmio Resgate

A segunda e mais impactante ação foi a Lei do Audiovisual (BRASIL, 1993). Ela trouxe a ideia de que a produção independente é aquela não vinculada à TV, estúdios ou distribuidores internacionais. Por meio de uma conjunção entre capital acumulado nas deduções no imposto de renda e investimento desse capital em ações dos filmes, os investidores também tinham garantias de ganhar com a divulgação das suas marcas nas obras, transformando-se num aprofundamento da Lei Rouanet. A diferença entre as duas é que, na Lei do Audiovisual, os financiadores fomentam a produção e não se apropriam dos direitos autorais na comercialização da obra, a não ser que as empresas estrangeiras utilizassem outra possibilidade da Lei: a coprodução. Nesse sentido, era possível a renúncia fiscal sobre as remessas de lucros ao exterior.

Tal conjunto de medidas influenciou novas divergências no setor cinematográfico, pois os filmes com orçamentos maiores eram mais bem quistos pelos investidores. Assim, uma ação para tentar atenuar a concentração dos recursos na década de 1990 foi a rearticulação do cinema regional. Estados e municípios passaram a deduzir o Imposto de Circulação de Mercadorias (ICMS) às empresas que investissem nas expressões artísticas, a começar por São Paulo, e, em alguns casos como Bahia, criou-se um Fundo de Cultura responsável por coletar e distribuir o montante arrecadado por meio de editais e prêmios. No caso do Ceará, o governo do estado criou o Instituto Dragão do Mar em 1996 e teve uma fonte mais complexa de recursos. ${ }^{26}$ A coordenação ficou a cargo de Maurice Capovilla e Orlando Senna

É importante destacar que Senna teve uma passagem na direção da internacional Escuela de Cinema e Vídeo de Santo Antonio de Los Baños, situada em Cuba. Ele integrou o movimento Cinema Novo desde a juventude na Bahia, quando conheceu Glauber Rocha, transitou pelo teatro, jornalismo, e foi roteirista e codiretor de sua obra cinematográfica de maior

26 Simis (1998) aponta que os recursos do Instituto foram oriundos do Fundo de Amparo ao Trabalho (FAT), Sistema Telebrás e Companhia de Eletrificação do Ceará (COELCE). 
reconhecimento: Iracema: uma transa amazônica (1974) com recursos da televisão alemã. Voltou para o Brasil para fundar um modelo similar ao de Cuba, dirigido por Darcy Ribeiro no interior do Rio de Janeiro, mas, com o falecimento do antropólogo e recuada do governador, desembarcou no Ceará.

$\mathrm{Na}$ época, a lacuna nas políticas culturais era tão grande que o Instituto Dragão do Mar tinha múltiplas funções até chegar ao resultado final, a começar pela formação de profissionais em áreas básicas nas artes. Durante quatro anos e meio, entre 1996 e 2000, foram quatorze longas-metragens finalizados, e oito mil alunos formados, até que por desavenças políticas, o governador desmontou todo o projeto de um dia para outro (SENNA, 2014, informação oral). ${ }^{27}$

Era visível a fragilidade das políticas nacionais e locais desde o começo, mas prevaleceu a euforia quando Carlota Joaquina: princesa do Brazil (CAMURATI, 1995) atingiu a marca de um milhão de expectadores em 1995. Foram as boas vindas para o governo Fernando Henrique Cardoso (FHC) dar continuidade à política de renúncia fiscal adotada. Mais ainda quando O Quatrilho (BARRETO, Fábio, 1995) ${ }^{28}$ foi indicado ao Oscar de filme estrangeiro, e Guerra de Canudos (REZEDE, Sérgio, 1997) ergue-se como a superprodução que marcou o ingresso da Globo no cinema como coprodutora e distribuidora em 1998.

Após três décadas de crescimento exponencial, a TV aberta demonstrava ser motriz na reconstrução do cinema. Independentemente da Globo Filmes, diretores e artistas com passagem na emissora, basicamente nas novelas, sintetizam a presença de profissionais que só tiveram a TV ou a publicidade como espaço de trabalho. Como exemplo é possível citar Pequeno Dicionário Amoroso (WERNECK, 1997) e Lavoura Arcaica (CARVALHO, 2001). Nesse campo de interação cinema/televisão, a TV Cultura de São Paulo também contribuiu nesse período, por meio do Programa de Incentivo ao Cinema (PIC), relacionando fomento e garantia de distribuição (MARSON, 2006).

Além da reaproximação com a TV, a publicidade também se relacionava com o cinema. Produtoras como $\mathrm{O} 2$ e Conspiração Filmes nasceram e sobreviveram num período de baixa dos longa metragens e crescimento da publicidade. Outra vertente que se manteve viva

27 SENNA, Orlando. Entrevista I. [nov. 2014]. Entrevistador: Pedro Andrade Caribé. Rio de Janeiro , 2014. 1 arquivo .mp3 ( $122 \mathrm{~min}$.).

28 Anita Simis (1998, p. 5) sistematiza o modelo econômico envolvido neste filme: "De su costo de 1.8 millones de reales, $R \$ 300$ mil salieron del bolso del propio productor, $R \$ 400$ mil se obtuvieron en préstamo por el Ministerio de Cultura en la fase de terminación; pero la mayor parte del dinero - un millón cien mil dólares - fue captado por medio de la Ley del Audiovisual". "Do seu custo de 1.8 milhões de reais, $\mathrm{R} \$ 300$ mil saíram do bolso do próprio produtor, $\mathrm{R} \$ 400$ mil se obtiveram por empréstimo do Ministério da Cultura na fase de finalização, mas a maior parte do dinheiro - um milhão e cem mil dólares - foi captada por meio da Lei do Audiovisual" (Tradução nossa). 
com a publicidade foi a animação. Os desenhos animados dos programas infantis da TV eram principalmente de origem estadunidense e japonesa. Os filmes da Turma da Mônica na passagem dos anos 1980 para 1990 fugiram à regra. Na Retomada, o festival Anima Mundi (1993) passou a estimular a produção para além da publicidade, e isso formou profissionais fundamentais na preparação para o crescimento da demanda com a TV por assinatura (CALVET, 2013). ${ }^{29}$

Eram os primeiros ensaios de coordenação da cadeia do audiovisual com profissionais, equipamentos e narrativas estéticas dialogando entre si. Para completar o cenário, o Plano Real influenciou a euforia do cinema, ao beneficiar parte da classe média que podia viajar com mais constância para Miami e também frequentar as primeiras salas multiplex.

Era preciso se preparar melhor para um redesenho no cenário quanto às formas de concentração e interesse dos grupos empresariais; também havia um novo paradigma tecnológico em curso - a digitalização -, afetando os padrões e recursos da produção, as negociações dos direitos autorais e, até mesmo, o parque exibidor. Além disso, já ocorriam experiências, inclusive entre produtores independentes, demonstrando que as distinções de linguagem para cinema, TV, série, filmes ou novelas deveriam ser repaginadas.

\subsection{A TV MODERNA}

A relação entre interesses estratégicos do Estado Nacional e televisão é intrínseca no Brasil. O fortalecimento da TV Tupi-Difusora, inaugurada em 1950, demarca uma característica que iria permear predominantemente o setor a partir de então: a exploração comercial de serviço público. A opção por esse modelo era uma demonstração de proximidade do país com as indústrias culturais dos Estados Unidos da América. Othon Jambeiro (2001) defende que, no caso brasileiro, suas singularidades estão, inicialmente, na fragilidade econômica da produção cultural e na forte capacidade regulatória remanescente da década de 1930 quando o Estado Novo solidificou os mecanismos de utilização do rádio em prol dos seus interesses políticos. Dessa forma, ele defende que, desde o seu nascimento, a TV, no Brasil, mesclou a utilização com fins comerciais aos interesses políticos hegemônicos no Estado, na maioria das vezes, com intervenção estatal, não somente nas concessões, mas também em financiamento, investimento publicitário e suporte tecnológico.

29 Luz, Anima, Ação. Direção: Eduardo Calvet. Local: Canal Brasil, 2014 
Apesar do caráter dependente do capitalismo, e, consequentemente, das indústrias culturais, Sérgio Mattos (2002) defende a tese de que as condições socioeconômicas e políticas do país têm predomínio sobre os fatores externos ao desenvolvimento da televisão. Por isso, ele vê com reticências a tentativa de encaixar a TV brasileira dentro de um quadro global. Sua abordagem segue por seis fases, em que as singularidades locais se sobressaem, tendo as definições estatais um papel determinante.

Desse modo, tanto Jambeiro (2001) quanto Mattos (2002) evidenciam a demarcação da autonomia do caráter nacional da produção cultural em comunhão com os interesses do Estado, ligada ao desenvolvimento capitalista do país. A modernidade, segundo eles, é o momento em que estes elementos se estabilizam por meio da TV Globo. Todavia, numa revisão, desde os primeiros anos da TV, é possível ver que a Globo representa um tipo ideal que oculta uma série de elementos, também fundamentais, presentes na história da radiodifusão, e, até mesmo, presentes na sua própria história.

Ao revisar a história da televisão brasileira, Ângela Carrato (2013) defende que o discurso da modernidade oculta elementos chave ao seu desenvolvimento. O primeiro elemento é a desconstrução do mito de que Assis Chateaubriand foi o responsável por colocar no ar a primeira transmissão com apoio de empresas privadas. O personagem pioneiro para a autora é Roquette-Pinto. Este se dedicou, além do rádio, desde 1936, ao audiovisual, aliando-se ao cineasta Humberto Mauro para criar o Instituto Nacional do Cinema Educativo (INCE), com o objetivo de transformar as imagens e sons simultâneos em ferramentas educativas. Até que sua persistência aliada às habilidades intelectuais deram resultado:

De tanto ler e estudar sobre o assunto, ele montou, em 1943, em sua pequena oficina, uma televisão primitiva à base de processos mecânicos, utilizando o disco de Nipkow. Seu objetivo era buscar maneiras para ampliar o espaço para a educação e a cultura. E foi pensando nisso que realizou a primeira transmissão de imagens no Brasil. Para tanto, instalou a emissão na sede da Rádio Sociedade na rua da Carioca, no centro do Rio de Janeiro, e um receptor na casa de um amigo, localizada na rua Cândido Mendes, no bairro de Santa Teresa. Ele realizou uma única transmissão, o suficiente para provar que o engenho funcionava. As imagens transmitidas eram as de um cartaz com as letras A, B e I, formando a sigla da Associação Brasileira de Imprensa. No futuro, o cronista Antônio Maria destacaria esse fato, lembrando que graças a Roquette-Pinto, as primeiras imagens mostradas pela TV brasileira não foram as de um anúncio comercial nem o retrato do presidente da República. (CARRATO, 2013, p. 105)

Somente sete anos depois, Chatô conseguiria inaugurar a primeira transmissão comercial, enquanto isso o projeto de Roquette-Pinto de investir numa emissora pública era engave- 
tado em 1952, mesmo com recursos alocados e testes técnicos estabelecidos. Nesses primeiros anos, predominaram os altos custos dos aparelhos televisivos somados aos limites tecnológicos, que só permitiam programas ao vivo e produzidos localmente. Era um artigo de luxo disponível essencialmente apenas nas cidades de São Paulo e Rio de Janeiro. O imaginário inicial da TV, segundo Marialva Barbosa (2010), era acompanhado pela valorização de sua capacidade tecnológica, em especial nos anúncios de venda da General Eletric. Barbosa (2010) também questiona as leituras que apresentam a TV como amadora em seu surgimento, ao contrário, a pesquisadora defende um alto grau de planejamento envolvendo patrocinadores, empresas estadunidenses e Estado por quatro anos, até a TV Tupi de Assis Chateaubriand ir ao ar.

Nesse período inicial, Renato Ortiz (1991) e Cristina Brandão (2010) apontam que o rádio e o teatro eram as duas principais influências no conteúdo da $\mathrm{TV}$, enquanto o cinema das chanchadas era desprezado pelas elites da época. O teleteatro representava uma valorização do teatro, com teor mais elitista e adaptações literárias. Já a novela tem sua origem na radionovela, e era tida como produto de qualidade inferior no período.

No geral, a produção nacional de sons e imagens simultâneas era frágil, o cinema não se solidificara, e a influência estrangeira era forte, tanto que as novelas tiveram nas soap opera uma matriz. Originárias dos Estados Unidos, as soap opera se reconfiguram na América Latina a partir de Cuba antes da Revolução (1959), por meio de releituras dos folhetins. O viés comercial prevalece nas obras sob o patrocínio de empresas como Colgate-Palmolive e Gessy-Lever (ORTIZ, 1991). Nessa perspectiva, existem opiniões teóricas divergentes quanto ao poderio das agências publicitárias e anunciantes nas primeiras novelas da $\mathrm{TV}^{30}$.

Por outro lado, Renato Ortiz (1991) destaca a não existência de uma indústria internacional de televisão solidificada. Os EUA particularmente atrasaram em quase vinte anos os investimentos, a fim de preservar o rádio e o cinema, e, somente na década de 1940, as primeiras outorgas passaram a ser distribuídas. Isso significa que a influência estrangeira era forte, mas não o suficiente para impedir uma autonomia no seu desenvolvimento, ainda mais ao lidar com um conglomerado notável liderado por "Chatô" e outras tentativas não menos ousadas como as TVs Rio, Record e Excelsior.

Outro elemento que demonstra os potenciais da televisão nacional é a estratégia de relação com o público. Alexandre Bergamo (2010) alerta que a televisão tem a família nuclear

30 Na mesma publicação - Telenovela: história e produção" (1998) -, Renato Ortiz (1998, p. 42)defende que as emissoras sempre tiveram propriedade do conteúdo nas telenovelas, e algumas páginas depois, num texto em conjunto de Ortiz com Silvia Borelli (1998, p. 60), os autores trazem um relato de que as agências definiam o conteúdo em conformidade com os patrocinadores. 
de classe média como referência para o conteúdo ficcional, inclusive, para a publicidade. Bergamo (2010) destaca que os períodos iniciais de experimentação e adequação à família vão ser recontextualizados com a relação estatística com o "público", inclusive sob uma noção moral de quem são e de como vivem essas pessoas a serem representadas nas obras televisivas.

Na passagem para os anos 1960, tal relação com o público é oxigenada por um cunho nacionalista, influenciando artistas e diretores que passam a desenvolver textos próprios, que se relacionam mais com a realidade do país. Nesse momento, a TV Rio e a Excelsior dão uma grande contribuição para o desenvolvimento da televisão, conforme elucida o resgate de Henrique Costa (1986) sobre o percurso das empresas. No caso da TV Rio, ele ressalta o investimento em profissionais já tarimbados do rádio como Geraldo Casé, e o lançamento de outros que moldam suas trajetórias na TV e são conhecidos, até, pelas gerações mais novas, a exemplo de Jô Soares, Léo Batista, Cid Moreira, Ronald Golias, Walter Clark e José Bonifácio de Oliveira Sobrinho, o Boni. A TV Rio também levou ao ar o primeiro Jornal Nacional com transmissão simultânea em duas localidades, Rio de Janeiro e São Paulo, por meio de investimentos próprios numa empresa de telecomunicações, e com o suporte de micro-ondas.

A conexão entre linguagem e tecnologia era tão importante que a emissora foi a primeira a utilizar o vídeo-tape, em 1960, no programa Chico Anísio Show, e chegou a se preparar inicialmente para a transmissão em cores, mas não teve fôlego, ou apoio estatal. Quanto ao vídeo-tape, vale uma menção especial: a necessidade da transmissão ao vivo e as influências do rádio e do teatro foram substituídas por gravações, roteiros e cenários mais arquitetados e editados, mais próximo do processo produtivo do cinema, principalmente, nas novelas.

O mercado de televisão passava a ser mais cobiçado, e um dos maiores monopolistas brasileiros da época, a família Simonsen, resolve entrar no negócio por meio da Excelsior. A base do capital era a exportação de café, algo que lhe colocava no pedestal internacional, inclusive em disputas com empresas europeias. Os Simonsens se interessavam por um governo nacionalista, e passaram a investir na TV para apoiar Jânio Quadros e depois João Goulart na presidência da república. O montante de dinheiro foi suficiente para retirar parcela dos profissionais da TV Rio e enfrentar a Tupi, ao tentar, em vão, articular a REI (Rede de Emissoras Independentes) junto com a Record. Apesar de seu esforço, com a Ditadura Civil-Militar (1964-1985), findava a possibilidade de construir outro modelo de rede, balizado em relação de maior autonomia com os associados (COSTA, 1986).

Mas, nem tudo foi jogado no ralo junto com a ditadura e a perseguição econômica aos Simonsens. O espírito empresarial da Excelsior foi responsável por inovar, ao criar um slogan 
para vender a si própria, e, principalmente, trazer o princípio de programação horizontal e vertical dos EUA, inclusive com a seção "Cinema em Casa”, que, todos os dias à noite, apresentava grandes obras cinematográficas. As novelas também foram alvo de investimento da Excelsior, e, conforme Ortiz e Borelli (1991, p. 58) estas foram responsáveis por especializar a atividade profissional com roteiro, diretores, atores, produtores e vendas: "Mentalidade empresarial que pressupunha o rompimento com um tipo de produção mais artesanal e a instauração de uma divisão de trabalho e de funções mais acentuadas".

A Tupi também teve seus atributos que marcam o desenvolvimento não só da TV, mas de qualquer outra mídia que almeja a concentração. Aproveitou as oportunidades tecnológicas, a ampliação do consumo e o poder político para conectar um sistema de comunicação. Foi beneficiada com o barateamento no acesso aos receptores, o surgimento do vídeo-tape e do satélite; e, paulatinamente, passou a obter licenças, comprar ou submeter emissoras locais à rede Diários de Associados, espalhada por todas as regiões do país, na qual a TV foi precedida pelos jornais, pelas revistas e pelo rádio, na primeira grande concentração de grupos nas comunicações brasileira. Montava-se, assim, um modelo como o que ainda persiste, com alto grau de interferência política. ${ }^{31}$

Entre os anos 1950 e 1960, a TV Tupi também se preocupou com um conteúdo que a associasse ao público. Estreou o primeiro programa humorístico com Mazzaropi, apostou no jornalismo com o Repórter Esso, transmitiu, ao vivo, a inauguração de Brasília antes do sistema de satélites, e levou ao ar as primeiras novelas dirigidas por Janete Clair; inclusive o sucesso Beto Rockfeller (1968), inovador na linguagem e nas estratégias mercantis ao adotar o merchandising.

A crescente participação da TV no bojo dos investimentos publicitários foi acompanhada de maiores interesses políticos, expostos nos debates, em 1962, para a promulgação do ainda vigente Código Brasileiro de Telecomunicações (CBT), sendo que, até então, havia instabilidades sobre os critérios. ${ }^{32}$ A legislação é inicialmente copiada integralmente do rádio e, já no retorno de Getúlio Vargas (1951-54), há uma série de instrumentos normativos e decretos, que, inclusive, chegam a tornar a renovação das outorgas obrigatória a cada três anos.

No governo Juscelino Kubitscheck (1955-61), intensifica-se o relacionamento da TV com o projeto econômico, que deixa como marca a desobrigação das emissoras com programas educativos, o que incluiu não destinar recursos advindos da publicidade para tais fins. Jânio Quadros (1961-1962) também tenta deixar marcas: estabelece cotas na programação para

31 Ver Lima e Capparelli (2004).

32 Conforme levantamento de Jambeiro (2002). 
os filmes nacionais, cria o Conselho Nacional de Telecomunicações (Contel) e torna a Voz do Brasil obrigatória.

Mas, tudo seria, aparentemente, derrubado quando o Congresso Nacional liderou o Código Brasileiro de Telecomunicações (CBT), posteriormente acompanhado pelo Regulamento dos Serviços de Radiodifusão (1963). Um processo com densa participação de congressistas, alguns já radiodifusores, ou mesmo, futuros. Processo esse que fez surgir a Associação Brasileira das Emissoras de Rádio e TV (Abert) e firmar uma cultura de lobby e clientelismo no Congresso envolvendo a radiodifusão,

O primeiro passo do CBT foi a criação de uma estrutura estatal de telecomunicações. No acompanhamento das licenças e execução administrativa, manteve o Contel e criou o Departamento Nacional de Telecomunicações (Dentel), ambos, posteriormente, substituídos pelo Minicom. Para investimento e acompanhamento da infraestrutura, criou a holding empresa de Telecomunicações Brasileira (Telebrás), responsável por amplo processo de estatização do setor, tendo a Empresa Brasileira de Telecomunicações (Embratel) seu principal braço, devido o monopólio das operações em longa distância.

Quanto às regras para exploração: estabeleceu a renovação entre dez e quinze anos, limites de outorgas por concessionário, caracterizou permissão (retransmissão) e concessão (execução); tornou a propaganda política partidária obrigatória; bem como estipula um percentual de conteúdos educativos e noticiosos; e, por fim, limita o tempo da publicidade. Nesse período, também já havia ciência quanto à utilização de tecnologias como satélite, UHF e cabo, todos interligados no mesmo Código ao VHF, FM, AM e telefonia. Apenas a indústria do cinema se manteve fora do CBT.

Foi, nesse contexto, instaurado o alicerce regulatório da radiodifusão brasileira ainda persistente. Por isso, não é exagero interpretar que, antes da TV Globo ir ao ar, as emissoras presentes já confluíam com elementos chave da modernidade. As bases regulatórias para a expansão comercial da televisão estavam erguidas, bem como a expertise técnico-estética e a relação com o público no mercado publicitário.

\subsubsection{O moderno não é novo}

A formação de aparato regulatório em torno do CBT e sistema Telebrás permitiu à Ditadura Militar efetuar o controle no conteúdo e infraestrutura conforme seus interesses políticos e econômicos. O investimento na televisão seria ainda mais robusto, mas precisava de 
uma parceria mais promissora que a Tupi. Foi, então, que apareceu Roberto Irineu Marinho. Apoiador do Golpe, ele já detinha propriedade de jornal e concessão de rádio, e partiu para a televisão ao inaugurar a Globo em 1965. Rapidamente, o grupo se tornou parceiro ideal dos militares, não só na cumplicidade política, mas também pela racionalidade administrativa para fortalecer a produção de conteúdo nacional. Mas, antes, teve de passar por um processo que o tornava mais dócil aos militares: a CPI do caso Time-Life colocou na berlinda o futuro da emissora, e trouxe, na sua gênese, conflitos com elementos chave da modernidade televisiva.

Daniel Herz (2009) revela os mecanismos ilegais utilizados desde 1961, quando a Globo arquitetava a expansão para a TV. Tal percurso se coadunou com o crescente investimento de capital estrangeiro nos meios de comunicação do país. O grupo Time-Life, associado à Columbia Broadcasting Sistem (CBS), desde o início da parceria, investiu na montagem e firmou acordos que chegaram a representar $45 \%$ das ações. E não se restringiu a isso, pois as cifras ultrapassaram em dez vezes o patrimônio da Globo e envolveram cláusulas para treinamento técnico, formação administrativa, assessoramento de engenharia, orientação para compra de produtos estrangeiros e abertura para inspeções.

Os órgãos de fiscalização não detinham acesso pleno às informações do contrato que acabou permitindo o controle a um grupo estrangeiro de uma emissora nacional, algo mal quisto por um setor dos militares, por políticos mais conservadores como Carlos Lacerda, por alguns parlamentares da Arena, e, até mesmo, por outras empresas de comunicação. Membros da Abert, entre os quais a TV Rio, criticaram esse acordo, já que perdiam, paulatinamente, seus profissionais, a exemplo do diretor de programação José Bonifácio Sobrinho, o Boni, e o gestor Walter Clark (HERZ, 2009).

Presidido por Castello Branco (1964-1967), o Executivo tomou conhecimento e solicitou medidas por meio de uma Comissão de Alto Nível e, depois, administrativamente no Contel. Já o Congresso, pressionado por mobilização da maioria dos órgãos de imprensa, instalou uma CPI e reconheceu, não só a ilegalidade, mas também a ameaça à soberania nacional em 1966. Todavia, o general Costa e Silva (1967-1969), que assumira a presidência e a procuradoria da república, resolveu acolher o pedido de revisão da Globo em 1967. O processo é, então, amornado, e, dois anos depois, a emissora passou a ser controlada apenas por capital nacional (HERZ, 2009).

O período mais fechado da ditadura se abria tendo como parceiro cativo a Globo e, passada a turbulência, a empresa de Roberto Marinho soube aproveitar uma série de mecanismos de estímulo, desde o aumento da publicidade estatal até a qualificação da rede de infraes- 
trutura. A ampliação do crédito ao consumidor para arregimentar o "milagre econômico" com o consequente aumento na compra de aparelhos é acompanhada pela ação da Embratel, por meio do Sistema Nacional de Telecomunicações no fim da década de 1960. Foi, então, que o projeto de rede nacional se tornou mais viável, permitindo a centralização da produção, até em tempo real, facilitando, inclusive, os mecanismos de censura. Nesse momento, somente a experiente Tupi e a nascente Globo conseguiram aglomerar as emissoras regionais, e torná-las afiliadas.

Para a Globo chegar rapidamente a esse patamar, também teve de fazer o "dever de casa". Num período ainda elitizado e moralista, começa investindo em programas popularescos, definidos por Inaiá Simões (1986, p. 79) como práticas populistas heterodoxas: “algo sem perfil definido, e que na prática se baseia num sistema consolatório, que distribui justiça a varejo, oferece prêmios, localiza parentes perdidos, arranja casamentos, arbitra litígios entre vizinhos etc.". O maior efeito ao angariar este público estava na formação de uma ideologia de consumo, porque a maioria da audiência não acessava os produtos ofertados na publicidade. $\mathrm{O}$ importante era querer participar do mundo representado na programação.

A partir do departamento de pesquisa com o público, a Globo reduziu as possibilidades de errar na audiência, e a renovação estética se expõe no Jornal Nacional com mudanças de linguagem para um "padrão de qualidade" viabilizado pela utilização de uma câmera de cinema cp (cinema product) que gravava imagens e sons simultâneos, aumentando a credibilidade e integração do público com a TV..$^{33}$ A relação entre cinema e jornalismo também esteve presente no Globo Repórter, que contou com o trabalho de documentaristas como Eduardo Coutinho, Doc Comparato e Wladimir Carvalho a partir de 1973.

Na passagem para os anos 1970, os militares também passaram a adotar duras restrições ao conteúdo em programas de audiência relevante como os de Flávio Calvacanti e Jacinto "Homem do Sapato Branco". Mas, o momento era de predomínio das formas ficcionais, e, sem um cinema capaz de dar sustentação, o caminho foi da "integração vertical". Ou seja, total controle sobre o processo de produção, distribuição e venda, sendo as telenovelas da Globo um marco, por desenvolver um padrão de qualidade de padrão internacional, envolvendo tradição de gênero (folhetim), tecnologias, gestão, profissionais e cenários (ORTIZ, 1995).

Aliás, desde 1966, a emissora deixa de ser dirigida por artistas e passa a ser conduzida por publicitários e profissionais do marketing. Estimulada pelo sucesso de Beto Rockfeller na Tupi, especializa sua produção, incorpora o realismo nacional e um misto de louvação e crítica à modernidade com Janete Clair (Os Irmãos Coragem [1970-1971] e Pecado Capital

33 Ver Sacramento e Ribeiro (2010). 
[1975]). Já em 1969, inaugura a Som Livre, a fim de ocupar espaço no mercado fonográfico associado às novelas.

Para Maria Rita Kehl (1986), no geral, a programação da Globo chega aos anos 1980 como representação do Brasil moderno: industrializado e urbano. Entre os Planos Nacionais de Desenvolvimento do governo militar, estava o Plano Nacional de Cultura, ou seja, entrelaçado a objetivos militares de higienização da identidade nacional com o capitalismo vigente, ao ponto de fragilizar o imaginário construído no Cinema Novo. "A estética brilhante e clean da publicidade e do 'padrão-Globo-de-qualidade' foi se tornando hegemônica e inviabilizou em poucos anos a estética do cinema novo e dos Centros Populares de Cultura" (KEHL, 1986, p. 202).

A relação do cinema com a televisão não foi apenas de exclusão. Orlando Senna (2014, informação oral) enxerga uma complementariedade nas entrelinhas nos dois projetos estimulados durante os governos militares:

\footnotetext{
"A ditadura teve preocupação de dizer: "Somos modernos. O cinema, a tv, as estradas. Somos contemporâneos ao acontece com o mundo inteiro". Já que a imagem real era desastrosa. Isso não é uma coisa a ser confirmada com provas e documentos, mas a história nos mostrou como complementação. Se a ideia é colocar a tv no brasil inteiro, tem que ter conteúdo, Por isso o governo militar se interessou na ideia dos cineastas. Teve complementação porque a Embrafilme foi firmada com muitos recursos e durou muitos anos. Não acho que foi por acaso, O Golbery, o grande intelectual, não faria algo aleatório. Eles estavam dando muito dinheiro para as empresas privadas.”
}

A vedete do cinema novo, Glauber Rocha, tentou se reposicionar com a perda de espaço no modelo comercial da Embrafilme. No fim da década de 1970 passou a ser o apresentador do programa "Abertura”, na decadente Tv Tupi, ao lado de outras personalidades como João Saldanha, Sérgio Cabral, Walter Clark, Antonio Callado, Ziraldo, Norma Bengell, Roberto D'Àvila, entre outros. Regina Mota (2010) interpreta o programa como analogia ao momento político do país com altos índices de audiência, superando o Fantástico. Todavia, essa história é ocultada, e, até mesmo, as empresas de publicidade se negavam a investir num formato inovador, fora dos padrões e também do controle dos anunciantes. Dessa forma, ele é um símbolo que a maior relação com o cinema nacional poderia promover uma diversidade ética, estética e política.

José Mário Ortiz Ramos (1995) define, por meio de análises da programação, que a novela passa a dominar a grade e a competir com a produção importada de filmes na entrada da década de 1980. Mesmo sem um fluxo dinâmico de integração com o cinema nacional, 
principalmente na ficção, estavam presentes aspectos embrionários da futura Globo Filmes por meio de Os Trapalhões. Estes foram responsáveis por associação entre sucesso de bilheterias e audiência na televisão, pela produção independente e mesclando elementos tradicionais, populares e da cultura de massa. O quarteto liderado por Renato Aragão deu passos à frente do seu tempo:

nasceu como ramificação da atividade televisiva, se consolidou com o aproveitamento de condições mesmo insuficientes do cinema brasileiro, sentiu a necessidade de retornar ao "cinema de estúdio" que sempre se mostrou inviável no país, enfim, se adequou à nova situação audiovisual no país. (RAMOS, 1995, p. 43)

Além de ampliar a relação com o cinema, a tecnologia é um mediador aproveitado bem pela Globo para assumir a posição hegemônica. Foi a primeira a usar o editor eletrônico, e deu um salto com a decisão do governo brasileiro em adotar o sistema PAL-M da TV em cores. A opção nacional foi escolha singular no mundo e, assim, evitou importação de aparelhos e estimulou o parque tecnológico. Todavia, só a Globo conseguiu se sair bem financeiramente com os investimentos necessários para a transição cromática (SIMÕES, 1986). Outro salto dar-se-ia em 1983, quando passou a utilizar o satélite Intelsat ${ }^{34}$ e abriu possibilidades de internacionalização e, principalmente, de consolidação num país com dimensões continentais.

Já a relação com o consumidor, enquanto uma das fases da circulação, foi também aperfeiçoada pela Globo por uma série de medidas destacadas por Maria Rita Kehl (1986): implementação da noção de "público-alvo"; venda de publicidade conforme audiência; fim do sistema de patrocinadores; e inserção de um mecanismo de venda rotativo, "obrigando" o anunciante a comprar um pacote de horários, e não apenas o instante que lhe interessava - o que permitiu evitar a veiculação de muitos comerciais de baixa qualidade. Depois, veio a inserir a venda por módulos selecionados conforme a audiência e o perfil dos programas para uma semana inteira, e não apenas um dia. Por fim, a Globo concentrou, mas não deixou de relevar singularidades regionais, desde que detivessem poder de consumo. No caso do Rio Grande Sul, a autora defende que os hábitos culturais foram mais respeitados, e se desenvolveu uma estratégia singular com preponderância da TV Gaúcha, e, posteriormente, a primeira rede regional, a Rede Brasil Sul (RBS).

34 O Intelsat foi um consórcio, liderado pelo EUA, sendo o Brasil o $11^{\circ}$ associado, responsável por colocar o primeiro satélite de comunicação em órbita em 1965. 


\subsubsection{A modernidade do atraso}

A década de 1980 se iniciou com o fim da Tupi, e alguns elementos se destacaram nesse processo. O mais ressaltado deles foi a fragilização do grupo após a morte de "Chatô". Os antigos sócios passaram a ser proprietários regionais, resultando em dispersão administrativa; e também deixaram de ter como aliadas políticas preponderantes as elites políticas da época, em especial os militares. Independentemente do fim da Tupi, a Globo irrompe a década com um predomínio na audiência jamais visto na sua história, seja no passado ou num futuro não muito distante.

Antes de deixar o comando do poder Executivo, o militares estavam preocupados com a sustentabilidade do modelo adotado e também com a supremacia da Globo na televisão, que já era o meio de comunicação mais importante do país. Por isso, no governo de João de Baptista Figueiredo (1979-1984), passou-se a estimular o crescimento de novas redes, oferecendo benefícios técnicos - como acesso ao Sistema Nacional de Telecomunicações, créditos e concessões - , tendo como referências desse momento o surgimento do Sistema Brasileiro de Televisão (SBT), a extinta Manchete e o amadurecimento da Bandeirantes.

Sílvio Santos já era apresentador consolidado no país, porém, seu estilo "popularesco" perdia espaço na Globo, que, por sua vez, buscava um padrão estético que pudesse se conectar com mais força com as classes A e B, alvo dos principais anunciantes. Ainda em 1974, ele inaugura a TV Studio no Rio de Janeiro visando mais a produção independente e se associa à Rede Tupi e à Record. Além do próprio Programa Sílvio Santos também investe em Moacir Franco, Raul Gil e O Homem do Sapato Branco. Em 1980, os militares resolvem viabilizar o investimento de Sílvio Santos com a criação do SBT. Ele obtém emissoras da falida Tupi e realiza a proeza de transmitir ao vivo a cerimônia de outorga da concessão. A base do conteúdo já estava desenvolvida e obteve rapidamente audiência, mas não reconhecimento dos principais anunciantes (MIRA, 2010).

Dois anos depois de inaugurado, o SBT adota um processo de modernização e racionalidade administrativa, o que "significa perda de autonomia dos produtores culturais em função de uma melhor adequação ao mercado, com o propósito de aumentar a vendagem" (MIRA, 2010, p. 167). A Praça é Nossa é o maior exemplo da repaginação de programa popularesco por meio de melhorias técnico-estéticas para Maria Celeste Mira (2010): cenário, sonorização, edição, captação de imagem, cores, figurinos, entre outros.

O importante é demonstrar que conteúdos com fortes traços do rádio se restabeleciam na televisão. O popularesco não foi uma invenção da Globo nos seus primeiros passos na TV, 
existia desde o período inicial mais elitista e moralista. O que não se pode negar é que, desta vez, o crescimento fez a Globo se mexer, primeiro ao repatriar Chacrinha (1982), e, depois, Faustão (1989). O curioso é que, na Globo, esses mesmos perfis de programas não são comumente adequados como popularescos, demonstrando que a tal modernização do "Padrão Globo" passa por equilíbrio que mescla quantidade e perfil da audiência (MIRA, 2010).

$\mathrm{Na}$ outra ponta do SBT, Manchete e Bandeirantes priorizavam classes mais abonadas. César Bolaños (2004) ressalta o investimento tecnológico das emissoras. A Bandeirantes, existente desde 1969, atravessa um longo período, basicamente, como programadora de filmes e programas estrangeiros de baixo custo, até iniciar a década adotando um sistema da Sony de gravação, edição e exibição; mesas de corte, vídeo-tape e equipamentos para geração de imagem da francesa Thompson; novas linhas de transmissão; e construção de estúdio no Rio de Janeiro. O empreendimento da família Saad passa por instabilidade nessa virada, abdica um pouco dos programa de análises e debates de informação, até se equilibrar com o esporte a partir da chegada de Luciano do Vale em 1983 (BOLAÑOS, 2004).

Durante a década, também se fortalece a figura do produtor independente para televisão. Na maioria, oriundos da publicidade, passam a trafegar no cinema e TV. Nomes como Walter Salles e Fernando Meirelles se apresentam nesse período. No caso de Meirelles, ao lado de Marcelo Tas, defende uma concepção de vídeo do autor, em que, a criatividade e inovação se mostram fundamentais num ambiente engessado da TV. Eles se valem, em grande medida, de novas possibilidades tecnológicas como as fitas Umatic e Betamax que permitiam mais habilidade e movimentação desde a filmagem até edição e montagem. Num momento de queda do cinema nacional, a TV é quase monopolista na circulação do conteúdo, e o entusiasmo com o vídeo independente no período alcança um status político (WAISMANN, 1988).

A Globo se movimenta sem sair dos trilhos, sua fórmula sintetizada no "Padrão de Qualidade" segue se diversificando. Desde anos 1970, os seriados e, posteriormente, as minisséries foram fontes de inovação na Rede Globo. Eles também utilizam os equipamentos portáteis antes restritos ao jornalismo, a exemplo de Morte e Vida Severina (AVANCINE, WALTER, 1981): Tal equipamento possibilitou fazer teledramaturgia em locação, isto é, fora do estúdio, e, com isso, os seriados ganharam as ruas e as minisséries passaram a explorar temáticas regionais (BECKER, 2010, p. 244).

Apesar de papel relevante desde então, a literatura especializada sobre os seriados e minisséries é escassa. Na década de 1980, Malu Mulher (1979-81), Carga Pesada (1979-81), Armação Ilimitada (1985-88) e TV Pirata (1988-90) são exemplos que atravessaram o tempo. Ao utilizar horários menos exigidos pelos anunciantes, poderiam desenvolver linguagens e te- 
mas mais arriscados do que os das novelas. ${ }^{35}$ Mesmo com produção nacional majoritária nas obras ficcionais, nesse período, os produtos estrangeiros também têm espaço na Globo. Antes de o apresentador Fausto Silva atravessar as tardes de domingo, Alf, o ET teimoso, Magnum, A gata e o rato e Profissão perigo eram transmitidos antes de a atração principal, Os Trapalhões, entrar no horário nobre.

A diversidade não exclui a manutenção das novelas ("das oito") no eixo do conteúdo ficcional na Globo. Roque Santeiro (1985), após ser proibida pelos militares, retorna no período mais intenso da redemocratização, após o movimento "Diretas Já!” (1984) e eleição e morte de Tancredo Neves. Esther Hamburger (2005) a analisa como marco de transição e de modernização que não se abstém do passado, ao contrário, o revigora. Referências ao cinema novo, a novelas de Janete Clair e ao cinema autoral norte-americano mesclam-se com novidades tecnológicas e mudanças de costumes, mediadas por um coronel, ainda peça chave nas decisões políticas e culturais da cidade.

O “coronel” também é peça chave nas comunicações desse período. A abertura política foi acompanhada pelo fortalecimento de concessões caracterizadas por negócios familiares e vinculadas às elites políticas regionais, desde que comprometidas com a chefia do poder nacional. Tal relação clientelista teve condução das autorizações pelo Ministério das Comunicações (Minicom), tendo, no governo Sarney (1985-1989), a passagem emblemática de Antônio Carlos Magalhães (ACM) como ministro. Ambos, Sarney e ACM, também se tornaram concessionários e afiliados da Rede Globo nos seus estados de origem, Maranhão e Bahia, respectivamente.

Santos e Caparelli (2005) contextualizam que o conceito de coronelismo é formulado por Victor Nunes Leal e se refere à instalação da República Velha, quando os coronéis municipais controlavam o processo eleitoral em voto aberto por coerção. Assim, os donos da terra estabeleciam suas relações com o poder público local e, principalmente, estadual-nacional, dando base política em troca de favores, prática presente num período de transição que se renova na década de 1980. Sem a censura prévia, era o momento da programação regional ou local ficar vinculada aos interesses eleitorais dos proprietários no "coronelismo eletrônico"36":

35 Amâncio e Bahia (2010) defendem que TV Pirata e Armação Ilimitada prenunciam uma narrativa transmidiática, por estimular uma paródia-reflexão da TV e por mesclar linguagens da publicidade, quadrinhos, cinema e rádio, respectivamente.

36 Venício Lima (2011) adiciona mais uma categoria para este fenômeno: o coronelismo eletrônico de novo tipo. Tal situação viria a ocorrer majoritariamente na década de 1990 com o fortalecimento do município enquanto ente federativo na Constituição de 1988, e às permissões e autorizações para a exploração de outorgas de rádios FM e comunitárias (legalizadas, ou não) a cargo de prefeituras e câmaras municipais, e, ou políticos com atuação efetiva num muncípio. 
Essa configuração política tem vital importância no cenário das comunicações dada a posição estratégica da televisão aberta como principal meio de informação do país e por ser um meio de recepção gratuita. Através dos antigos coronéis políticos se transformaram em coronéis eletrônicos, que, em lugar da propriedade rural, usam agora a propriedade de estações geradoras e retransmissoras como forma de extensão dos seus poderes. (SANTOS; CAMPARELLI, 2005, p 78)

Tal quadro se encaixa no modelo da Globo: no Brasil, os termos do negócio na formação das redes televisivas deixam para a "cabeça" o predomínio na produção de conteúdo e também a legitimidade para negociar com os grandes anunciantes. Os recursos arrecadados com a publicidade tendem a ser repartidos com as filiadas, afiliadas e retransmissoras, conforme a força econômica da praça na qual está situada. Além disso, as afiliadas e filiadas também faturam com publicidade local. No caso das parceiras da Globo, a vantagem por estar associada à marca de grande audiência permitiu sustentabilidade financeira de alguns grupos regionais (JAMBEIRO, 2004). Por outro lado, a maioria das afiliadas e retransmissoras são negócios frágeis e, embora sejam fundamentais para as grandes redes se desenvolverem e até alçarem mercados internacionais, no geral, os interesses políticos acabam prevalecendo na difusão da informação dessas empresas (SANTOS, 2004).

Foi com tais práticas clientelistas na comunicação, que a Constituição de 1988 foi redigida. Concessões se tornaram moedas de troca para aprovar pontos de interesse do Executivo, e isso afetou diretamente os próprios artigos do Título VII, Capítulo V destinado à Comunicação Social. Atendendo aos desejos da Abert, o Congresso Nacional passou a complementar o Executivo, pois as comissões temáticas da Câmara e do Senado passaram a ser responsáveis pelos pareceres de liberação e renovação, que, depois, seguem para validação da Presidência da República. Só ficou a cargo exclusivo do Congresso a cassação, ou não renovação. Fora isso, ocorreram alguns avanços como o fim da censura, o impedimento a monopólios e oligopólios (Art. 220), a inclusão de princípios de diversidade e éticos (Art. 221), e a criação do Conselho de Comunicação Social (Art. 224).

$\mathrm{Na}$ teoria, a mudança mais brusca da Carta Magna na radiodifusão está no artigo 223, ao criar o princípio da complementariedade entre privado, estatal e público. Sob essa perspectiva, é necessário que as outorgas estejam atuando nos três regimes. Mas, desde Roquette-Pinto, a televisão pública e, até mesmo, a estatal têm suas iniciativas apagadas. O motivo não é aleatório. Desenvolver conteúdos sem estar refém da audiência e balizado por finalidades educativas e culturais tem potencial que poderia ao menos amenizar o poderio das empresas comerciais. Por isso, vale retomar a análise de Ângela Carrato (2013). 
A autora aponta correntes, no seio dos militares, interessadas em estimular conteúdos de teor educativo. Dessa forma, no início da ditadura (1965), são reservados, no espectro, espaços para os canais educativos no VHF e UHF. Somente em 1967, é criada a primeira emissora educativa: a TV Universitária de Pernambuco, vinculada ao Ministério da Educação. O ritmo é lento, e, dez meses depois, mais oito são liberadas, ${ }^{37}$ inclusive aquelas que vão protagonizar o serviço por mais de trinta anos: o governo paulista cria a TV Cultura de São Paulo dois anos depois (1969), e demora mais quatro (1973) para a TV Educativa do Rio de Janeiro ser registrada, subordinada ao próprio governo federal.

A TVE-RJ tem como impulso para sua implantação e afirmação o trabalho de um discípulo de Roquette-Pinto, Gilson Amado, que começou como produtor independente para as televisões comerciais por meio da Fundação Centro Brasileiro de Televisão Educativa (FCBTVE) em 1967. O primeiro conteúdo a ter destaque foi uma telenovela voltada para o supletivo do extinto $1^{\mathrm{o}}$ grau, João da Silva (1973). Posteriormente, apareceu a primeira telenovela infantil do país, Pluft, o fantasminha (1975), e também desbravadora do horário das $18 \mathrm{~h} 00$ para as telenovelas. Por último, o Sítio do Pica Pau Amarelo (1977), uma adaptação das obras de Monteiro Lobato, apoiada, na época, pela TV Globo, foi premiada pela Unesco (1979) e segue, até os dias de hoje, atingindo o público infantil por meio de novas leituras e linguagens: produtos de merchandising, animação e games. Mas, o reconhecimento por meio da concessão no espectro, anteriormente ocupado pela TV Excelsior, não significou transmissão imediata da TVE-RJ. Carecendo de recursos físicos e humanos, só em 1977, passa a ter uma programação estável.

Já a emissora paulista teve apoio dos industriais do estado e, segundo Carrato (2013, p. 188) "pode ser considerada uma espécie de eco da Revolução de 1932, associada ao fascínio que parte dessa elite nutria em relação à cultura europeia”. Ela também se valeu da parceria com a TV Globo, nesse caso, obtendo ampla repercussão com o programa infantil Vila Sésamo (1972). ${ }^{38}$

Percebe-se que a Globo está atenta aos potenciais dos conteúdos das emissoras educativas. Cossete Castro (2005) resgata que, desde a origem, a programação educativa ${ }^{39}$ faz parte do grupo, e, na mesmo época em que sua hegemonia se constitui, parte para outro passo: a cri-

37 As outras seis são: TVE do Amazonas, a TVE do Ceará, a TVE do Espírito Santo, a TVE do Maranhão, a TVE do Rio Grande do Norte e a TVE do Rio Grande do Sul.

38 Vila Sésamo é uma adaptação brasileira da série estadunidense Sesame Street, da Children's Televisom Workshop (CASTRO, 2005).

39 A autora rejeita uma divisão muito segmentada entre gêneros ao considerar educação tanto os infantis, instrucionais, seriados, técnicos, profissionalizantes e, até mesmo, aqueles voltados para o entretenimento, sem uma valoração moral ou ética. 
ação da Fundação Roberto Marinho (FRM) em 1977. A tática para seu desenvolvimento é velha conhecida das empresas de mídia do país: benefícios estatais, dessa vez, por meio de abatimento em impostos e captação de recursos no MEC. Foi assim que, um ano depois, transmite em parceria com a Fundação Padre Anchieta, responsável pela TV Cultura/SP, o Telecurso Segundo Grau (TSG).

Num país com dimensões continentais e educação básica precária, o TSG foi inspirado no Projeto Satélite Avançado de Comunicações Interdisciplinares (SACI), desenvolvido inicialmente pelo governo federal no Rio Grande Norte, dotado de tradição na alfabetização de jovens, adultos e leigos por meio da atuação de Paulo Freire. O SACI funcionou entre 1972 e 1976 utilizando um satélite doméstico e produziu 1.241 programas de rádio e TV.

Além dos objetivos de mercado, a atuação da Globo na educação demonstra expertise para se relacionar com o público não apenas como números, mas também em questões essenciais, reconhecidas como direitos. Tal cenário cidadão estava mais ávido quando o país se deparou com o processo Constituinte na redemocratização. Os princípios da Carta Magna apontam a liberdade de expressão e o direito à informação como fundamentais, e, não à toa, a sociedade civil ecoava vozes que tentavam incidir na formulação, haja vista a Federação Nacional dos Jornalistas (FENAJ) e a Frente por Políticas Democráticas de Comunicação. Mas, a modernidade na televisão brasileira construía, mais uma vez, uma noção de direitos assentada em privilégios.

Após a Constituição de 1988, o Congresso Nacional se tornou o espaço majoritário nessa correlação entre concessões de radiodifusão e política, pois as comissões temáticas da Câmara e do Senado são responsáveis pelos pareceres pouco transparentes de liberação e de renovação, depois, seguem para validação do Executivo Federal. Contudo, não apenas via Executivo ou Legislativo, são formados os grupos na radiodifusão. Nem mesmo a política e os negócios são os únicos pilares para se apropriar do setor, a religião também tem histórico de dedicação à radiodifusão e, nesse caso, refuta a modernidade enquanto processo progressivo de laicização do Estado.

Os católicos, que representam a maior porcentagem dos religiosos declarados no país, têm orientação do Vaticano de 1963 para explorar a propriedade e conteúdo dos meios de comunicação e a utilizavam majoritariamente por missas e celebrações (SANTOS, 2004). No caso dos evangélicos, conforme cresciam em número de seguidores, ainda na década de 1980 , construíram seus alicerces em um mercado, por vezes obscuro, de compra e venda de empresas de comunicação, conforme aponta um ex-pastor da Igreja Universal do Reino de Deus (IURD): 
O estádio da Fonte Nova estava completamente lotado. Repetia-se em Salvador o fenômeno do Maracanã, no Rio. Naquela tarde, depois de recolher os envelopes com o "sacrifício" e com os pedidos de oração, que seriam levados para o monte das Oliveiras, em Jerusalém, o bispo [Edir Macedo] pediu aos seus seguidores baianos uma oferta especial para comprar uma emissora de rádio em Salvador, assim como seus fiéis cariocas o haviam contemplado com a rádio Copacabana. Será que os cariocas tem mais fé que os baianos; perguntou o bispo a multidão. NÃO! - a resposta retumbou como um trovão. As ofertas vieram em forma de dinheiro e joias. Passamos três dias trancados em uma sala contando os sacos de dinheiro levantados no Fonte Nova. No final, o dinheiro foi depositado na conta da Igreja, no Bradesco, em Salvador. (JUSTINO, 1995, p. 10)

Nesse momento, os programas nas rádios serviam exclusivamente para arrebatar novos fiéis para a IURD. Por sua vez, os fiéis eram transformados em eleitores, e, desde o pleito de 1986, a IURD já pedia votos, nos seus cultos, a parlamentares direta ou indiretamente ligados a ela. No ano de 1989, o brasileiro voltava às urnas para escolher o primeiro presidente da república após a ditadura militar, e a IURD se transformou em um cabo eleitoral significativo, tanto que Fernando Collor de Melo pediu diretamente apoio ao bispo Macedo, o que foi correspondido através de campanha aberta nos cultos (TAVORALO, 2007).

Depois de obter as primeiras concessões de rádio, o bispo Macedo iniciou processo de aquisição da TV Record em São Paulo, sob intermédio do ex-deputado federal Aproveita Vieira, em 1989. A concessão da Record estava sob a guarita de Sílvio Santos - também proprietário do SBT - e da família Machado de Carvalho. ${ }^{40}$ Apesar das dificuldades financeiras da emissora, havia interessados com sustentáculos políticos e econômicos, a exemplo do grupo Abril e do ex-governador paulista Orestes Quércia, mas o bispo Macedo foi mais hábil nas negociações (TAVORALO, 2007).

No transcorrer do ano de 1992, a disputa era para que o Estado permitisse a transferência na concessão da Record, enquanto o país passava por nova agitação política, desta vez, na que resultou no impeachment do, então, presidente Fernando Collor. O bispo só teve a confirmação da legalidade num dos últimos atos do chefe do Executivo nacional, já ciente de que iria ser deposto após pressão das ruas, do Congresso e dos principais meios de comunicação da época. Antes disso, ainda em 1992, Edir Macedo chegou a passar alguns dias na cadeia, sob acusação de charlatanismo e estelionato. ${ }^{41}$ A prisão repercutiu, a Rede Globo esperava

40 A compra da Record é permeada de dúvidas sobre a origem do dinheiro. O ex-pastor da IURD, Carlos Magno, denunciou que parte dos U\$\$ 45 milhões da compra foi oriunda de traficantes colombianos, numa esquema de lavagem de dinheiro (GUIBU, 1995). As interrogações sobre a legalidade das compras de empresas de comunicação pela IURD permanecem. O Ministério Público Federal reabriu inquérito que aponta os mecanismos utilizados pelos bispos da IURD nessas transações (AGUIRRE, 2011).

41 Edir Macedo foi atacado em 1992, mas também teve defensores, seu advogado para sair da cadeia foi o exMinistro da Justiça, Márcio Thomaz Bastos, e o então presidente do Partido dos Trabalhadores (PT), Luís Inácio Lula da Silva, condenou o gesto da Justiça e da polícia (TAVOLARO, 2007). 
Macedo na porta da delegacia após ser detido, e, segundo o pesquisador Gabriel Priolli, solidificou posição editorial da emissora contrária a IURD (apud TAVORALO, 2007).

O repasse da Record para o grupo da IURD é o marco de tendência singular e crescente na radiodifusão brasileira: as Igrejas Eletrônicas. Católicos e outras igrejas evangélicas também entraram e intensificaram o negócio a partir da década de 1990, seja por meio da compra de espaço para transmissão de cultos ou mesmo pela propriedade, mas nenhum deles alcançou o status da IURD-Record. Um fator decisivo, a que se interessa esta pesquisa, é que os novos concessionários da Record se propuseram a priorizar as potencialidades comerciais, sem desconectar aos interesses e mecanismos políticos que cercam a radiodifusão no país (SANTOS, 2004).

A TV Record foi a segunda emissora inaugurada no país, em 1953 na capital paulista. Na sua primeira fase, até 1989, a programação conseguia ter respaldo no público através dos pilares que permeiam, até o momento, as principais redes do Brasil: entretenimento, esportes e jornalismo. ${ }^{42}$ Resgatar a áurea de credibilidade da emissora foi opção do bispo e de seus parceiros para amenizar as influências da IURD sobre o conteúdo e obter audiência mais ampla. $\mathrm{Na}$ primeira década da renovação, alguns programas deixaram marcas na TV nacional: Ana Maria Braga com culinária, Eliana para o público infantil, Raul Gil e Fábio Júnior com música e auditório, Bóris Casoy no jornalismo, o policialesco Cidade Alerta com Datena, o popularesco Ratinho Livre, novelas nacionais, seriados e filmes estadunidenses.

Os programas religiosos foram ocupando horários secundários na emissora, como o Fala que Eu Te Escuto nas madrugadas, porém se tornaram fortes mecanismos para amenizar questionamentos jurídicos acerca dos repasses de recursos da IURD para a Record, o que representa um percentual de receita privilegiada para a emissora em comparação com suas concorrentes. ${ }^{43}$ Outro fator não abandonado pela Record, em relação às demais Igrejas Eletrônicas, é a articulação com produtos culturais religiosos como livros, discos e seriados.

Enquanto aumentava a audiência, também aumentava a cobertura geográfica. "No final de 1998, a Record levava sua imagem a praticamente todo país, cerca de $90 \%$ do território nacional, no mesmo nível, portanto, das redes SBT e Bandeirantes" (LIMA; CAPPARELLI,

42 Em alguns momentos, a antiga Record chegou a alcançar a liderança e deixou marcas como festivais de música popular brasileira, um programa da jovem guarda, o humorístico Família Trapo e início de Os Trapalhões; apresentadores de auditório como Hebe Camargo, Chacrinha, Silvio Santos, Raul Gil e Faustão; filmes de faroeste e séries estadunidenses, a exemplo de Rin Tin, Tin, Chips e S.W.A.T; programas de futebol como Olho no Lance, por Sílvio Luiz; e novelas escritas por Janete Clair e Benedito Rui Barbosa. Sucessivos incêndios, parceria ambígua com Silvio Santos e a supremacia da Rede Globo foram fatores que levaram a Record à beira da falência até ser comprada (AMORIM, 1999).

43 Somente em 2010, foram injetados R 428 milhões da IURD na Record, valor que representa 25\% do total do faturamento desse ano. Ainda assim, no "Diário Oficial Empresarial". a emissora fechou o ano com prejuízo de R\$ 1,7 milhão (FELTRIN, 2011). 
2004, p. 35). Antigas associadas das concorrentes foram sendo incorporadas pelo empreendimento do bispo sem os mesmos objetivos religiosos, outras foram adquiridas como foi o caso da TV Itapoan na Bahia, que viria a se tornar sede da Record Nordeste em 2007.

No fim do século XX a Record proliferava, bem como a importância política da IURD. Ainda em 1998, a força do poder político do grupo é demonstrada no fato de o bispo alegar ter sido procurado pelo ex-governador do Distrito Federal, José Roberto Arruda, a fim de patrocinar a reeleição de Fernando Henrique Cardoso (TAVARALO, 2007).

Pois bem, o ingresso da Record na década de 1990 demonstra que, 25 anos após o CBT, debates represados no período ditatorial não tiveram oportunidade de expansão na Constituinte. E foi, dessa forma, que as eleições de 1989 demarcaram capacidade desproporcional de incidência de uma rede de televisão na vida pública. A Rede Globo seria peça chave no apoio à eleição de Fernando Collor de Melo, distorcendo debates e ressaltando notícias negativas dos demais candidatos, algumas delas farsantes como o envolvimento do Partido dos Trabalhadores (PT) no sequestro do empresário Abílio Diniz.

Nesse período, novas possibilidades tecnológicas já estavam em prática ou estavam por vir. Não à toa, a digitalização e a alta definição já apontavam tendências, e os satélites e a tecnologia à cabo já eram amplamente utilizados no mundo. Na publicação "TV ao vivo: depoimento" (1988), a experiência de profissionais brasileiros alerta que a alta definição transmitida por satélites iria tornar obsoleta a TV analógica por tubos de raios catódicos. O futuro seria a digitalização por meio de transmissão de informação por códigos binários, que além de não perder qualidade na transmissão, também permitia a quebra de incompatibilidade entre equipamentos. Novas formas de relação com o público também são registradas. A fibra ótica permitiu a bidirecionalidade, ou seja, o receptor podia enviar dados para além da voz na telefonia, e o Video Homer System (VHS) é apontado como liberador, porque permitiu escolher o que e quando assistir, sem ficar refém das emissoras de TV e exibidores de cinema. Por sinal, os anos 1990 chegam com proliferação de locadoras de vídeos no país, enquanto as salas de cinema fechavam.

Mas, antes de avançar na globalização da televisão, vale introduzir um ator: a TV por assinatura. 


\subsection{A TV GLOBAL}

Ao discutir a TV por assinatura, o poderio na infraestrutura se torna sedutor, pois, geralmente, os detentores das infovias são aqueles que acumulam mais capital e também passam a ter uma ingerência significativa no conteúdo. No processo da Lei do Cabo, membros estatais, academia e movimentos sociais buscaram desenvolver uma noção de transporte público , e, assim, a operação das redes físicas seria acompanhada por regras de interesse público, em que o fluxo de dados poderia sofrer menos restrições.

Além de regulamentação frágil do cabo, já com a LGT, a noção de interesse privado passa a prevalecer, e a TV paga se desenvolve no país, na década de 1990, sob concentração que casava infraestrutura e conteúdo. Nesse momento, já não se utilizam os conceitos de interesse público com a mesma ênfase dos formuladores da Lei do Cabo, mas objetivam-se regras que incorporam princípios envolvidos nesses conceitos, a começar pelos limites à concentração e o estímulo à diversidade cultural.

Faremos o retrospecto até chegar neste cenário por meio dos mediadores e suas dinâmicas de interação, mas, antes, vale também demarcar rapidamente uma característica epistemológica recorrente: a conjunção entre os discursos da modernidade e globalização quanto à noção de ruptura histórica. Na modernidade do cinema e televisão, novas formas de produção são acompanhadas por interesses do Estado nacional. Já na globalização da TV por assinatura, a revolução tecnológica advinda com a digitalização, satélites, fibras óticas e microprocessadores, viabiliza a concentração e expansão de conglomerados midiáticos e informacionais para além de suas fronteiras, recorrendo, inclusive, na maior participação de acordos e organismos multilaterais nas decisões nacionais, configurando uma nova política. ${ }^{44}$

O que buscamos evidenciar é que a perpetuidade da noção de ruptura é acompanhada por elementos causais na modelação de uma estrutura ou sistema. Já a rede é tecida por vínculos que se fazem e refazem conforme a performance dos atores e actantes nos mediadores destacados, e, em vez de algo novo, a rede se constitui como algo singular num determinado tempo e espaço. O que interessa preponderantemente à pesquisa não é reificar essa singularidade, e, sim, estar aberto a descrever as conexões responsáveis por constituir singularidades ininterruptas.

A história das telecomunicações se aproxima dos dois séculos de existência. Briggs e Burke (2006) resgatam que, em 1837, a invenção do telégrafo elétrico permitiu separar o fluxo de mensagens e o transporte de pessoas e mercadorias. As mensagens, mais rápidas, pas-

44 Ver Lima (2004). 
sam a ser peça chave na soberania nacional e transações comerciais, e se fortalecem como uma mercadoria por si só. Assim, mesmo antes da eletricidade, os autores defendem que a decisão regulatória passa a alterar significativamente a história. O processo é o mesmo: influencia o ato de um governo permitir ou investir na utilização das tecnologias comunicacionais, e cada governo, por sua vez, está inserido em contextos geopolíticos, científicos ou econômicos para tomar decisões. Política e técnica estão relacionadas.

As técnicas tidas como originárias passam por processos de aperfeiçoamento e alteram substancialmente o potencial comunicativo. Em alguns casos, podem criar outro meio, como, por exemplo, a junção entre eletricidade e acústica criou a telefonia, que, diferente do telégrafo, permite a comunicação ponto a ponto e o entretenimento.

Na década de 1970, os chefes dos Estados nacionais já tinham conhecimento de que as técnicas passavam por um aperfeiçoamento ou alteração significativa. O paradigma da comunicação de massa e seu papel no desenvolvimento, discutido desde os anos 1950 na UNESCO, reestruturava-se para o paradigma da Nova Ordem Mundial da Informação e Comunicação (NAOMIC). A pressão, a partir dos países do Terceiro Mundo e dos Não Alinhados, fez-se presente na própria UNESCO, responsável por alçar o relatório “Um Mundo e Muitas Vozes”, até hoje, considerado o mais completo documento quanto às implicações da comunicação nas sociedades contemporâneas.

EUA e Grã-Bretanha se retiram e esvaziam o órgão, e passam a centrar forças na União Internacional de Telecomunicações (UIT), insatisfeitos com a avaliação do relatório de que cada país deveria ter autonomia para decidir a forma como adotaria as tecnologias, a fim de enfrentar a possibilidade de novas formas de desigualdades entre os povos se erguerem, devidas a disparidades no conhecimento tecnológico e domínio de fontes de informação.

Nesse período, o Brasil estava sob uma ditadura, apoiada pelo governo dos EUA, mas, sob uma política internacional balizada na autonomia, assim como a política tecnológica, tendo como vetor chave a construção da infraestrutura e serviços de telecomunicações. Os militares fortaleceram o CBT, não apenas para estimular a radiodifusão, mas também as potencialidades da telefonia e demais fluxos de dados em desenvolvimento, como micro-ondas e satélites, além de indústria de equipamentos e um centro de pesquisa - o Centro de Pesquisa e Desenvolvimento em Telecomunicações (CPqD). Foi assim que o Sistema Telebrás se consolidaram na década de 1970, distribuído em todo território nacional a partir de processo de estatização e investimentos.

Estava em curso o que Murilo Ramos (2000) defende como a primeira onda da globalização na televisão brasileira, não apenas no vanguardismo nacional ao integrar o satélite In- 
telsat. A associação da Globo com a Time Life, anteriormente relatada, chegou a ensaiar uma virada na autonomia nacional, mas a política do período rapidamente a fragilizou "conforme os padrões políticos, econômicos, culturais e técnicos da época” (RAMOS, 2000, p. 126) para predomínio do caráter nacional.

Já a segunda onda da globalização a que Ramos (2000) se refere, passa-se no período em que técnicas hegemônicas buscam hegemonizar outras técnicas em casamento com a remodelação do Estado a fim de favorecer empresas transnacionais. Fragiliza-se a ideia de nação, em prol de ingressar numa aldeia global (MCLUHAN, 1964) vendida como irreversível: “A segunda onda é fruto de uma lógica de globalização informativo-cultural, caracterizada por uma crescente interpenetração não apenas de conteúdos, mas principalmente de fortes interesses empresariais" (RAMOS, 2000, p. 138).

A TV por assinatura emerge nesse contexto, na passagem para os anos 1990. Samuel Possebon (2011) resgata todo seu histórico desde sua fase incipiente na década de 1950, e observa iniciativas regulatórias paralisadas entre 1975 e 1979 pelos militares, em parte, por pressão oriunda de grupos da Universidade Federal do Rio Grande do Sul (UFRGS) e da Universidade de Brasília (UNB), ambos integrados por Daniel Herz. Na ocasião, os acadêmicos expuseram denúncias sobre a possibilidade de a iniciativa privada ser privilegiada no desenvolvimento a cabo difusão. Para além disso, não parecia estratégico abrir novas possibilidades de canais sem uma indústria audiovisual consistente no país nos anos 1970, e assim colocar sob instabilidade a aposta na radiodifusão e na Embrafilme. Até a segunda metade dos anos 1980, o serviço era circunscrito à transmissão de sinais de TV aberta por meio de dezenas de CATV (community antenna television). Já no fim da década, aparecem sinais mais intensos do seu florescimento e os grupos nacionais saem na frente.

Alijado da radiodifusão, o grupo Abril pressiona o governo Sarney para liberar a faixa do UHF e, dessa forma, cria o Serviço Especial de TV por Assinatura - a Televisão Abril (TVA) - , no qual a MTV seria transmitida a partir de 1990 sob controle da família Civita. A pressão continua por meio da recente Associação Brasileira de Antenas Comunitárias (Abracom), e surge o primeiro marco legal em 1989, o DISTV (Serviço de Distribuição de Sinais de Televisão), teoricamente restrito à venda em condomínios fechados e impeditivo da retransmissora tornar-se uma geradora.

Foi, então, que duas distribuidoras se destacaram com conteúdo estrangeiro: a TV Filme, em Brasília, utilizava o SHF para exibir o canal CNN durante a Guerra do Golfo (1991); e o Canal +, inspirado no homônimo francês, expandiu-se em São Paulo, e, além da CNN, ESPN e RAI, trouxe novidades tecnológicas como "som estéreo, tecla SAP, transmissões co- 
dificadas e a possibilidade de se assistir a todos os canais utilizando um mesmo decodificador" (RAMOS, 2000, p. 34).

Foi essa experiência paulista que se associou ao grupo Abril para criar a TVA em 1991. O sistema híbrido era instável com canais em UHF e SHF, e usava uma "gambiarra" para chegar até aos domicílios, envolvendo uma antena receptora no telhado, decodificador e passagem na antena coletiva, forçando um plano de aproximação com síndicos e administradores de condomínios. Mas, no conteúdo adicionou a MTV, somada a um canal independente nacional, e muitos filmes estadunidenses como chamariz, acrescidos posteriormente com a Home Box Office (HBO), constituíram uma fórmula pioneira na exclusividade, ou seja, as demais operadoras não poderiam usufruir dos mesmos canais.

O objetivo da restrição era concorrer com a Globo. O grupo empresarial de Roberto Marinho entra, por acaso, no ramo, após apresentar uma proposta para de levar conteúdo educativo via satélite na Banda $\mathrm{C}$ ao governo federal que a rejeita. A partir de então, cria a gênese da Globosat em 1991: distribuição de canais de esportes, notícias, show, e filmes em associação com a Paramount, Fox, Universal e MGM a fim de enfrentar a TVA. ${ }^{45}$

A esse respeito, Possebon (2009) apresenta uma ata assinada por Boni que elencou os objetivos iniciais do empreendimento: visava classes A/B, adultos, interessado na segmentação, e a concorrência era com vídeos e discos. A distribuição também era limitada, e utilizava sinais vazios do VHF, o que foi alvo de críticas porque era ilegal. A expertise no conteúdo e a fragilidade na distribuição foi melhor compreendida pela Globo, ainda em 1991, a partir de estudos sobre a tendência de concentração na operação, sob o conceito de Multi-System Operator (triplo player), e separação com a programação. Foi nessa lógica que a Globo passou a caminhar, buscou as licenças DISTV e a entrada no cabo sob estímulo da RBS, ou seja, já se associando a outros distribuidores, incluindo o capital estrangeiro.

Nessa fase, as empresas do grupo Telebrás tinham gabarito para buscar um posicionamento na distribuição. A técnica para convergir telefonia e telecomunicação no país se inicia com a mineira Telemig. Já a Telebahia inovou ao levar o serviço de dados até a última milha, e, assim, pretendia vender voz, vídeo e dados. A força das estatais é a representação de um país que atravessava a década de 1980 numa situação ímpar entre os países periféricos. Até a redemocratização nacional e o fim da União Soviética darem sinais de que o curso da história seria alterado. Ramos (2000) destaca ainda alguns paradoxos que se evidenciam nessa época. A começar por má qualidade da gestão e falta de investimento, seja por dar o comando de uma empresa estatal às mãos de políticos liberais ou por privatização branca:

45 São canais criados pela GloboSat Telecine, TopSports, Multishow e GNT. 
que consistia fundamentalmente no loteamento, entre aliados políticos, das presidências e principais diretorias fosse da holding Telebrás, fosse da Embratel e das subsidiárias estaduais. Essa política iria romper com o profissionalismo que, justiça se faça, prevalecera nas comunicações durante o regime militar. (RAMOS, 2000, p. 189)

No governo Collor, enquanto as TV por assinatura saíam do rascunho, além da Embrafilme fechar, o Minicom foi transformado em Secretaria e o desmantelamento da Política Nacional de Informática (PNI) inviabilizaram um futuro de autonomia tecnológica nas infovias e dispositivos complementares com a extinção da reserva de mercado para os empreendimentos domésticos.

Era um momento de abertura ao capital estrangeiro nas comunicações, mas também era tempo de democracia. A nova Secretaria Nacional das Comunicações (SNC) abriu audiências públicas para opinar sobre a regulação vigente, e o que suscitou um caminho até inesperado foi a minuta de uma portaria, regulamentando a DISTV em Serviço Especial de TV a cabo. A partir de então, desencadeia-se um dos momentos mais ricos na regulação do setor no país, relatado por Ramos (2000), um dos integrantes do processo por meio da articulação da sociedade civil liderada pelo Fórum Nacional pela Democratização da Comunicação (FNDC) e diálogo direto com empresários, parlamentares e representantes da Telebrás.

Dessa forma, foram formulados os conceitos chave da política para o cabo: rede única, rede pública e participação da sociedade. O objetivo era construir uma rede de estradas informacionais, envolvendo as diversas tecnologias existentes, sob exploração de empresas privadas, mas geridas sob princípios públicos, em especial, ausência de discriminação no acesso. Por fim, a sociedade teria mecanismos de participação garantidos, a começar pelo Conselho de Comunicação Social (CCS) definido na recente Constituição.

Ramos e os integrantes do FNDC chegaram a ensaiar, a partir da proposta para o cabo, uma ampla lei de comunicação, e apostavam que o atraso do país ao adotar o cabo poderia ser revertido numa adequação já às fibras óticas e à promissora internet. Mas, a primeira lei assinada por Fernando Henrique Cardoso ao assumir a presidência (1995) manteve o acordo restrito ao cabo. A medida é considerada a pioneira no teor liberal do mercado de televisão do Brasil. A partir de então, a exploração dos serviços passou a ser exclusiva de operadores privados, incluindo a participação do capital estrangeiro - em até $49 \%$ das ações de cada operador - , além da presença de executivos. Entretanto, a Lei também contemplou princípios democráticos assumidos pelo governo na agenda internacional e doméstica. 
Jambeiro (2002) analisa que as teses da NOMIC, então restritas aos ambientes intelectuais e organismos multilaterais, ganham capilaridade em partidos políticos na Constituinte e se perpetuam na sociedade civil por interseção do FNDC, que teve suas bandeiras consideradas diretamente na negociação da Lei do Cabo em temas como: reserva na grade de programação para canais de acesso e interesse público; conceito de rede pública e única; e ingerência do CCS na regulação.

Há de se considerar que parte da ambiguidade na exequibilidade da Lei do Cabo, quanto ao conteúdo, foi decorrente do processo de regulamentação. Na Lei, as operadoras foram obrigadas a carregar os canais abertos e outros oito canais básicos de utilização gratuita: TV Câmara, TV Senado e TV Justiça em nível nacional; e canais locais comunitário, educativo-cultural (público/estatal), universitário e legislativo. No caso canal do comunitário, foi novidade na história das comunicações, pois, até o momento, não havia sido aprovada sequer uma lei para as rádios comunitárias. Porém, esse canal, sob algumas exceções, não vingou, devido às debilidades impostas à sustentabilidade e também às apropriações por religiosos, políticos e até mesmo especuladores de "espectro".

Outro ator importante surgido com a Lei do Cabo foi o Canal Brasil. Ele nasce por uma manobra nos direitos e deveres das operadoras especificada na Lei:

IV - exibir em sua programação filmes nacionais, de produção independente, de longa-metragem, média-metragem, curta-metragem e desenho animado, conforme definido em regulamento a ser baixado pelo Poder Executivo, resguardada a segmentação das programações. (BRASIL, 2011)

Por isso, o que poderia ser um canal de administração pública, passou a ser privado, mais ainda, é uma associação da Globosat com figuras do "cinemão", em especial, Luiz Carlos Barreto, o "Barretão".

A Lei também abriu espaço para canais que se perpetuaram nas TVs paga e aberta. Assim que surgiram o SescTV e o Canal Futura, que apesar de não serem obrigatórios, alastraram-se nos satélites da Banda $\mathrm{C}$, emissoras universitárias e comunitárias sem capacidade para produzir conteúdo, e até mesmo concessionárias na TV aberta. No caso do Canal Futura, este dá continuidade aos planos da Fundação Roberto Marinho e, ao longo da sua trajetória, foi angariando apoio de fundações de grandes bancos privados, associações industriais e majors internacionais como Turner/CNN. E o SescTV tem recursos originários do Sistema S, ou seja, a partir de contribuições garantidas na Constituição e repassadas a um conjunto de instituições profissionais associadas ao comércio, transportes e indústria. 
Interessante notar que muitos desses canais, apesar dos princípios públicos, surgiam num ambiente privado e limitado da TV paga. Foi a partir daí que puderam se preparar para chegar à TV aberta, principalmente quando o país adotou o sistema digital e reserva espaço no espectro para quatro canais relacionados ao poder Executivo, cultura, educação e o canal da Cidadania. O sistema digital, além dessa reserva, permite que apenas os canais públicos realizem a multiprogramação, ou seja, numa mesma faixa do espectro até quatro canais podem ser exibidos.

Outra vertente na regulamentação do cabo foi a licitação dos operadores. Quando foi aberta, colocou regras rígidas no combate à propriedade cruzada das empresas que já detinham outorgas de TV por assinatura ou outro serviço de tele ou radiodifusão, o que não atingiu a Globo, porque já tinha as licenças DISTV, e deixou as empresas parceiras concorrerem a fim de formar a Net Serviços. Para completar, o processo se arrastou por cerca de três anos e encontrou um clima de crise financeira ao ser efetivado, diminuindo a concorrência e a consequente arrecadação. Entretanto, há de se considerar que o vínculo mais dinâmico para os princípios da Lei do Cabo não se executarem e expandirem como desejado começa no ano da sua aprovação, quando o Congresso Nacional dá prosseguimento à abertura do mercado, ao modificar a Constituição e aprovar a quebra do monopólio estatal nas telecomunicações. É, então, preparado o terreno para a privatização da Telebrás e Embratel, e a adoção da Lei Geral de Telecomunicações (LGT) em 1997.

Ambas sintetizam a sintonia dos governos brasileiros com a ordem neoliberal impulsionada pela nova política, tendo, dessa vez, pouco espaço para pluralidade política. No trecho seguinte de Clodoaldo Bueno (2011, p. 509) é resumido o quanto os EUA, fóruns multilaterais e capital internacional foram determinantes num modelo adotado que persiste até os dias atuais:

A abertura das comunicações no Brasil correspondeu ao maior negócio do mundo quanto à transferência de ativos de países emergentes para o centro do sistema capitalista. As pressões internacionais foram precoces e bem conduzidas. Durante a Rodada Uruguai, dizia-se que se tratava do setor com maior probabilidade de lucros nos países em desenvolvimento. Durante a reunião de Marrakesh de 1994 e no foro de Davos em 1997, os representantes norte-americanos exigiam a abertura incondicional como parte das regras da liberdade comercial. O projeto de lei de privatização da Telebrás foi concebido por agências do exterior e embutiu as pressões externas. Com efeito, o Congresso Nacional contratou a UIT, uma firma de assessoria da ONU sobre controle norte-americano, que por sua vez subcontratou a McKinsey \& Company. A LGT de 1997 veio a público como queriam o governo dos Estados Unidos e o global player estrangeiros... Consumada a alienação das comunicações, a ANATEL, agência reguladora do setor, tornou-se refém das multinacionais. 
Entre as reformulações expressas na LGT está a distinção entre regime público e privado. O primeiro ficou reservado apenas ao Serviço Fixo de Telefonia Comutada (STFC) e, por ser considerado essencial, tem como características metas de universalização, bens reversíveis à União e maior propensão a subsídios estatais. Os demais serviços, entre os quais as modalidades de TV por assinatura, ficaram caracterizadas pelo regime privado, propensos a planos de qualidade e mecanismos de combate à concentração, contudo frágeis. O MMDS e o promissor DTH passam a ser incorporados à LGT e regulamentados por decretos, e a internet virou basicamente o Serviço de Comunicação Multimídia (SCM), uma espécie de anexo que permitiu às empresas de telecomunicações associar a venda a outros serviços, e também maior facilidade para pequenos empreendedores obterem autorizações.

Marcos Dantas (2010, p. 56) privilegia enquadrar o predomínio dos serviços privados na LGT a um processo de conformação a um novo regime econômico-institucional baseado na livre concorrência e nas chamadas "leis do mercado", no qual: "os meios de acesso e os seus conteúdos podem deixar de ser considerados 'direitos humanos' e podem passar a ser distribuídos conforme as condições de renda ou capacidade de competir dos diversos agentes, segmentos sociais ou mesmo indivíduos". No Brasil da década de 1990, o consumo era tratado como traço de distinção. Poucos tinham renda suficiente para ter uma TV por assinatura em casa, e foi esse um dos vínculos para chegar ao ano de 2001 com a estagnação de 3,5 milhões de assinantes.

Além do consumo, outras questões precisam amadurecer para fortalecer a TV paga. Veremos, no próximo capítulo, como, a partir da necessidade de aperfeiçoar a identidade na programação, é possível relacionar a movimentação dos grupos empresariais envolvidos na plataforma e também a necessidade de mudanças regulatórias. Paulatinamente, a interação com as demais plataformas se intensifica, e a separação entre cinema, televisão aberta e por assinatura se tornam mais frágeis, forçando uma atualização do marco regulatório.

Modernas ou globais, as estruturas pré-determinadas para constituir a realidade podem deixar passar à nossa frente as dinâmicas dos vínculos que se fortalecem e enfraquecem na constituição da rede em questão. Por isso, nesse capítulo o objetivo foi demonstrar que os mediadores destacados nesta dissertação se movimentam há décadas, e o presente tal qual nos deparamos não deve ser reificado. 


\section{CAPÍTULO III}

\section{DISPUTAS E ASSOCIAÇÕES ANTES DA LEI}

Neste capítulo são resgatadas ações dos mediadores num contexto de maior fortalecimento dos vínculos entre eles. Veremos como diversos elementos caminham para serem reconhecidos na Lei 12.485 (BRASIL, 2011). O cinema brasileiro independente passa a buscar legitimação no conceito de audiovisual, e, dessa forma, a necessidade de normatizar fluxos com a televisão se torna mais latente. Embora essas reivindicações não sejam novidades na história, veremos como os canais desse grupo com o Estado se tornam mais intensos por meio do Ministério da Cultura. A partir da gestão de Gilberto Gil (2003-2008), o ministério passa a pautar, na agenda institucional, demandas do audiovisual independente, e, entre avanços e entraves, aos poucos, a Ancine passa a protagonizar a atuação na pauta.

Quanto à radiodifusão, a possibilidade de ampliar a competição entre as grandes Redes converge com o movimento de saída da Globo na distribuição dos serviços de telecomunicações após a crise financeira na virada do milênio. Dessa forma, a empresa passa a se dedicar com maior afinco na sinergia do conteúdo. Essa sinergia amplia as conexões da emissora com a produção independente e tem, na TV por assinatura, sob crescimento, uma plataforma estratégica para continuar a predominar no conteúdo em circulação no Brasil. Em nível institucional, o Ministério das Comunicações manteve traço histórico de corresponder aos anseios dos radiodifusores, em especial, com o ingresso de Hélio Costa, e foi, nessa conjuntura, que o Decreto da TV Digital coadunou com a sinergia da Globo. Enquanto isso, o Congresso Nacional também continuava a corresponder aos grandes grupos empresariais e às elites políticas nas comunicações eletrônicas. 


\title{
3.1 A RETOMADA DA CRISE
}

A criação da Globo Filmes e o lançamento de Central do Brasil (SALLES, 1998) no mesmo ano de 1998 representam que o vínculo entre cinema e televisão estava mais forte, apesar de a família Marinho não deter direitos patrimoniais sobre a obra em questão, ela teve papel importante de divulgação do estúdio. Foi a primeira emissora a transmitir em sinal aberto, ainda no frescor de 1999, e detinha atores comuns nas novelas e séries, como Fernanda Montenegro e Marília Pêra, na equipe de produção majoritariamente nacional. ${ }^{46}$ Em sua realização foram combinados: recursos da Lei do Audiovisual (BRASIL, 1993), de órgãos estaduais e municipais e de empresas privadas internacionais e nacionais; trabalho de produtoras nacionais e estrangeiras - Videofilmes (Brasil), Riofilme (Brasil), MACT Productions (França) e Cinematográfica Superfilmes (Brasil) - , e de distribuidora estrangeira - Europa Filmes -. A repercussão da película não poderia ter sido melhor, contando com um público de cinco milhões de pessoas ao redor do mundo e dezenas de prêmios em festivais de cinema, entre os quais o Festival de Havana, Berlim e Globo de Ouro, além de duas indicações ao Oscar, incluindo Melhor Filme Estrangeiro e Melhor Atriz Principal para Fernanda Montenegro.

Independentemente do reconhecimento da obra, muita coisa já estava envolvida no cenário com ares diferentes, e, assim, a Globo quis ir além:

\begin{abstract}
Sua entrada no mercado cinematográfico ocorreu, não por acaso, em momento de reestruturação produtiva e institucional do cinema nacional. A criação do departamento de cinema da empresa foi uma estratégia política da emissora, que sentiu sua liderança, como produtora de conteúdo audiovisual nacional, ameaçada pelo fortalecimento e modernização de outros meios, como as telefonias celulares e internet. (BAHIA, 2012, p. 150)
\end{abstract}

A euforia escondia uma bolha. A fragilidade da política lastreada em incentivos fiscais abriu uma nova crise enquanto as feridas do fim da Embrafilme permaneciam abertas. Dessa vez, os sintomas vieram nas denúncias de superfaturamento por meio da Lei do Audiovisual, e também a privatização das telecomunicações, que, até então, eram a principais investidoras no cinema nacional. Os recursos foram paralisados, e a imprensa, tendo como ápice a revista Veja, voltou a deslegitimar o cinema nacional de forma pejorativa, embasada na relação de mecenato da legislação e as fragilidades nas prestações de contas. O filme Chatô, ${ }^{47} \mathrm{a}$

46 Diretor: Walter Salles; Fotógrafo: Walter Carvalho; Roteiro: João Emanuel Carneiro e Marcos Bernstein; Coordenação de Produção: Bruno Barreto.

47 "O filme, uma biografia do empresário das comunicações Assis Chateaubriand baseada no best seller homônimo de Fernando Morais, estava orçado em R\$ 12 milhões e já havia captado mais de 7 milhões. O ator Guilherme Fontes, que não tinha nenhuma experiência em direção cinematográfica, começou a captar recursos em 1996, e pretendia desenvolver um projeto multimídia sobre Chateaubriand, que incluía, além do 
ser dirigido pelo ator Guilherme Fontes, sem qualquer experiência na atividade, foi o bode expiatório para a abordagem conservadora do problema.

As energias do período foram bastante direcionadas para os mecanismos de financiamento à produção, e até mesmo às fragilidades estéticas das obras. Tudo bem, o modelo tem deficiências que foram paulatinamente atenuadas. Entretanto, o pensamento industrial sobre o cinema requer ir além desses pontos, pensar todo o processo de circulação, ações estatais, articulação na sociedade civil e geopolítica internacional. E mais uma vez Anita Simis (1998) reaparece nesta dissertação para delinear um problema nevrálgico: a incidência estrangeira, particularmente de Hollywood, na exibição e distribuição.

Ao tratar das salas de cinema, o remake da autora sistematiza um quadro de decréscimo quantitativo - para além da média internacional e também expansão de novas formas de acesso como locadoras, CD's e TV por assinatura - recuperado paulatinamente pelo modelo multiplex, com ingressos até oito vezes mais caros que o praticado na década de 1980, e dominado por dois grupos norte-americanos (Cinemax e National Amusement). Nesse momento, o principal exibidor nacional, a Severiano Ribeiro, se associa a um grupo estrangeiro, pois até as taxas aplicadas para importação e remessas de lucros tornam o filme estrangeiro mais lucrativo no sistema cambial vigente.

Quanto à distribuição, Simis descreve que passa a ser dominada por grandes estúdios, então responsáveis por $85 \%$ da produção norte-americana (Columbia Pictures, Walt Disney, 20th Century Fox, MGMlPathe, Paramount, MeA/Universal, Warner Bros). Para o conteúdo chegar ao consumidor final, eles criam diversas barreiras aos competidores como: altos custos da produção e das campanhas publicitárias, controle sobre os artistas, venda casada por lotes e por fim, efetuam no Brasil dumping, ao deixar com o exibidor até $50 \%$ do faturamento dos ingressos, contra $10 \%$ do praticado no país sede.

Até aqui não há grande novidades no modus operandi envolvendo a produção, exibição e distribuição ao se comparar com os anos 1950. Nem mesmo a popularização da TV mudou esse panorama para as obras em longa-metragem, a falta de interesse em associar-se à produção independente permanece como traço desde a fundação da transmissão de sons e imagens simultâneas no espectro.

filme, uma sitcom, uma série de documentários para TV e fitas de vídeo para a venda em bancas de jornal. Um projeto extremamente audacioso, que contou, inclusive, com um acordo de coprodução com a empresa do cineasta norte-americano Francis Ford Copolla e, desde o início, apresentou despesas de produção muito elevadas para os padrões brasileiros (só para se ter uma ideia, Fontes comprou todo o equipamento necessário para a finalização do filme e montou uma empresa de finalização). Mas, em maio de 1999, Guilherme Fontes interrompeu as filmagens alegando falta de dinheiro para finalizar o filme e tentou conseguir uma autorização do Ministério da Cultura para captar mais dois milhões, além de pedir que os prazos para finalização fossem aumentados” (MARSON, 2006, p. 127). 
A proposta inicial da Globo Filmes de ser distribuidora, e assim comprar filmes independentes e circular internacionalmente com a expansão da empresa no período, se esvai no segundo ano da empreitada. Ela passa a partir de então a entrar como coprodutora e apoiadora, mas sem investir recursos financeiros diretamente na produção. Não dava para concorrer com a estrutura montada pelas majors norte-americanas, e por isso, passou a concentrar na produção e associações com as distribuidoras, seja para as salas de exibição, seja para a TV por assinatura, a exemplo dos canais Telecine e Universal. Aliás, está aí a novidade para Simis (Ibidem): a expansão da estratégia dos distribuidores-produtores estrangeiros na TV por assinatura.

Neste cenário, em que o discurso da globalização é acompanhado por concentração econômica por meio da articulação entre técnica e política, o "cinema nacional" se mobilizou de forma atípica ao longo de décadas, não apenas pela unidade, mas também por compreensão holística da circulação.

\section{2 "O POVO DO CINEMA" E III CBC}

O primeiro passo para enfrentar a bolha foi em direção ao Congresso Nacional ao retomar uma subcomissão no Senado para avaliar os problemas no setor, algo que não era prioridade desde iniciada a ditadura militar. Em vez de ficar imobilizado pelas denúncias sobre os gastos na produção, o segmento participa de audiências e contribui num relatório com propostas da subcomissão, ${ }^{48}$ “O Povo do Cinema”, entre 1999 e 2000. Carla Gomide (2011) resgata os discursos nas audiências públicas com o objetivo de relacioná-los com as tentativas de legitimação da produção independente em âmbito normativo tanto no cinema quanto na televisão. A figura do intelectual militante, na maioria das vezes legitimado pela direção cinematográfica, ou sob passagem no processo da Embrafilme, continua forte nos debates ${ }^{49}$, juntando-se no mesmo espaço aos novos cineastas e a complexidade de atores que viria a reconectar o grupo e os seus vínculos, por meio de novas associações, ${ }^{50}$ diálogo mais intenso com empresas transnacionais, e atuação de outras etapas da circulação. ${ }^{51}$

48 Os senadores que coordenaram os trabalhos foram José Fogaça (PMDB/RS) e Francelino Pereira (PFL/MG), respectivamente presidente e relator.

49 Gustavo Dahl, Nelson Pereira dos Santos, Luiz Carlos Barreto, Cacá Diegues, Sílvio Tendler, Roberto Farias e Severiano Ribeiro.

50 Neste ano, era criada a Associação Brasileira das Produtoras Independentes de Televisão (ABPI/TV) com o objetivo de articular o conteúdo independente com as programadoras e Estado. Embora não participasse das audiências, viria a cumprir papel chave no futuro.

51 Maria Dora Morão (USP), Sério Santeiro (UFF), Marcos Marins (mídia especializada e distribuição), Mariza 
O governo participa com o secretário para o Desenvolvimento Audiovisual do Ministério da Cultura, José Álvaro Moisés, e apresenta algumas diretrizes da suposta política que pretendia, entre outras coisas, estabelecer a Contribuição para o Desenvolvimento da Atividade Audiovisual (Condecine), prevista desde 1992. Por sinal, esse foi um dos pontos do relatório final com maiores consequências futuras na conjunção entre ações regulatórias e desenvolvimento de políticas públicas. Todavia: "Em nenhum momento na fala de Moisés surgiu uma sugestão concreta do Ministério sobre a parceria entre cinema e televisão" (GOMIDE, 2011, p. 91).

O segundo passo foi a realização do III CBC em 2000, quase cinquenta anos depois das primeiras edições, marcado pela unidade e autodeclaração de politização do setor. Além de nova crise, a proposta do MinC de destinar recursos de fomento para as emissoras de televisão impulsionou desde declarações contrárias de figurões como Cacá Diegues e "Barretão", até audiências no Senado, e assim foram ao III CBC ao lado de novos e pequenos membros do grupo. Entre 69 pontos da carta final estavam velhas demandas de fomento, cota na tela, distribuição e memória. E dessa vez a concepção sobre um órgão específico para o setor abarcava a televisão com 12 pontos, entre os quais: taxar em 3\% o faturamento das emissoras de TV aberta e por assinatura a fim de reverter recursos para a produção independente; regulamentar o Art. 222 da Constituição para reservar espaço ao conteúdo regional e independente; e por fim, revisar as recentes regras da TV fechada.

\subsection{A NOITE DO DELETE}

A subcomissão do Senado e o CBC confluíram para a criação do Grupo Executivo de Desenvolvimento da Indústria do Cinema (Gedic), integrado por membros de postos estratégicos do governo e sociedade civil, inclusive a Globo. ${ }^{52}$ Os resultados dos trabalhos aparentemente foram animadores, propunha-se uma integração jamais vista, no passado e até mesmo

Leão (produtora), José Carlos Avellar (Riofilme), Gabriel Prioli (TV PUC), Walkíria Barbosa (Festival de Cinema do Rio de Janeiro), Esdras Rubim (Festival de Cinema de Gramado), Leopoldo Nunes (Associação Brasileira de Documentaristas), Werner Schünemann (Fundação de Cinema do Rio Grande do Sul), Rodrigo Saturnino Brito (Columbia Pictures - Tristar e Buena Vista) e Bruno Wainer (Lumiére).

52 Governo: Pedro Pullen Parente (Chefe da Casa Civil da Presidência da República), Aloysio Nunes Ferreira Filho (Chefe da Secretaria Geral da Presidência da República), Ângelo Andrea Matarazzo (Chefe da Secretaria de Comunicação de Governo da Presidência da República), Francisco Correa Weffort (Ministro da Cultura), João Pimenta da Veiga Filho (Ministro das Comunicações), Pedro Sampaio Malan (Ministro da Fazenda), Alcides Lopes Tápias (Ministro do Desenvolvimento, da Indústria e do Comércio Exterior); Sociedade Civil: Gustavo Dahl, Carlos Diegues, Luiz Carlos Barreto, Rodrigo Saturnino Braga e EvandroGuimarães (Organizações Globo). 
num futuro próximo. Gomide (2011, p. 111-112) sintetiza com destreza os pontos chave na relação entre cinema e TV apontados pelo pré-projeto:

a) Cota de tela: cada emissora de televisão, aberta ou por assinatura, ficaria obrigada a exibir uma quantidade de filmes brasileiros de longa-metragem por ano. A cota sugerida para as emissoras de televisão aberta seria um filme brasileiro a cada 15 dias. Já as televisões por assinatura ficariam obrigadas a exibir um filme brasileiro por semana.

b) Associação na produção: as emissoras de televisão aberta e por assinatura deveriam investir $2 \%$ do seu faturamento publicitário na coprodução de filmes nacionais independentes. A emissora não poderia deter mais de $49 \%$ dos direitos patrimoniais do filme, e a primeira exibição do filme seria em salas de cinema.

c) Aquisição de direitos: as televisões aberta e por assinatura deveriam investir $2 \%$ do faturamento obtido com publicidade na aquisição de direitos de exibição de filmes brasileiros. O preço mínimo sugerido para a aquisição do filme nacional de longa-metragem seria equivalente ao custo médio de uma hora de produto televisivo dramatúrgico nacional, tendo por base o capítulo de uma novela. Sobre esse valor seria acrescentado um prêmio calculado a partir de $15 \%$ da receita bruta auferida em salas de exibição no primeiro ano de sua exploração comercial.

d) Promoção institucional, comercial e publicidade: parte do espaço publicitário das emissoras seria reservado à promoção do cinema brasileiro, conforme acordo de cada emissora com o órgão gestor. Seria dado um abatimento para a publicidade de filmes brasileiros, de $35 \%$ no horário nobre (das $18 \mathrm{~h}$ às $23 \mathrm{~h})$ e de $50 \%$ no restante do tempo.

A presença de representante da Globo, Evandro Guimarães, dentro do GEDIC não significou acordo fechado sobre os pontos. Além de viabilizar o desenvolvimento de possível concorrente na produção de conteúdo num momento a que a empresa ainda estruturava seu braço complementar, a Globo Filmes, um tabu estava em jogo: abertura das receitas obtidas com as verbas publicitárias. Essa é a maior fonte de receita da radiodifusão, que por sua vez, se vale da falta de informações públicas sobre o faturamento real obtido com essa fonte. No período havia outro endosso para não bulir nesse tabu: os gastos públicos em publicidade e propaganda essenciais para a construção do modelo de exploração comercial que não eram sequer abertos à sociedade. Foi então que aconteceu a chamada "Noite do Delete":

No último encontro de discussão do Ministro Pedro Parente com o Gedic e seu subgrupo de cineastas, quando estava encaminhada a formulação da proposta para a criação de uma Agência do Audiovisual, desceu alguém de um helicóptero e teve uma conversa com o próprio Fernando Henrique. Começaram então uma série de contraordens ao pessoal que estava trabalhando na formulação da agência e o próprio ministro Pedro Parente começou a "deletar" tudo o que se referia à televisão. (SENNA, 2007) 53 $^{53}$

53 Disponível em: $<$ http://www.cartamaior.com.br/?/Editoria/Midia/A-noite-do-delete-ou-quando-a-Ancinavreduziu-se-a-Ancine/12/13738>. Acesso em: $1^{\circ}$ jan. 2015. 
Picotado o documento, surgiu a Política Nacional de Cinema e a Ancine,${ }^{54}$ sem o termo audiovisual e por meio de Medida Provisória nº 2.228 (BRASIL, 2001) em setembro de 2001. As agências reguladoras erguidas no país na década de 1990 partiram, na maioria das vezes, da quebra do monopólio estatal ou da concessão de serviços essenciais num setor, ou mesmo da necessidade de dinamizar a atividade econômica ao atrair investimentos, impedir a concentração e qualificar a relação com o cidadão-consumidor. A ideia base não era desenvolver uma atividade, e, sim, moldá-la para um quadro mais competitivo. No entanto, o panorama da época não dotou as agências da capacidade propagada, e os discursos de eficiência, governança e autonomia se mostram contraditórios.

No caso da Ancine, suas especificidades, ou melhor, fragilidades, começam ao ser criada para regular um segmento interligado para além das divisões institucionais e políticas entre comunicação e cultura. A comunicação, por sua vez, já estava repartida no paradoxo da radiodifusão Vs. Telecomunicações, enquanto a cultura era comandada por um ministério frágil, sob políticas sociais distorcidas nas ações de renúncia fiscal. Dessa feita, as atividades normativas cinematográficas e vídeo-fonográficas se mostram insuficientes por si só desde a origem. Provavelmente, na década de 1950, essa ideia de regulação teria sentido, mas não nos anos 2000. O audiovisual teve que se construir sob atividades desarticuladas no Estado, mas já vinculadas e dialogando com os demais mediadores destacados nesta dissertação.

Outra especificidade da Ancine está no fato de ser a única que mescla, além da regulação o fomento. No fundo, a perda de disputa com a radiodifusão e os programadores estrangeiros da TV por assinatura demonstra que sua capacidade fiscal nasce ainda mais incipiente, reduzida basicamente à atuação do mercado cinematográfico exibidor e distribuidor, aos mecanismos de renúncias fiscal, ou mesmo à sua própria atuação como agente fomentador do mercado. Quanto ao fomento, esse sim foi o ponto inegociável dos cineastas no período. A presença pujante de diretores nas movimentações do cinema independente e nacional sintetiza um olhar mais preocupado em conseguir realizar uma obra em longa-metragem. Mais ainda, somente poucos teriam condições de realizar obras subsidiadas, tanto pelos limites quantitativos de arrecadação da Ancine, quanto por critérios internos de destinação. Por isso, somente dez anos depois, a Ancine daria um novo salto com a "Lei da TV Paga". Até lá, a mobilização continuaria, a começar na transição entre os governos FHC (1999-2002) e Lula (2003-2006).

54 O nome original do órgão era Agência Nacional de Cinema e Audiovisual (Ancinav). 


\subsection{AS EXPECTATIVAS NA TRANSIÇÃO}

Fortalecer a Ancine para viabilizar a produção independente não era uma questão para a Globo no período. Seu braço no cinema andava em confluência com a TV e tem como marco O Auto da Compadecida (ARRAES, 2000). Considerado por Lia Bahia e Tunico Amâncio (2010, p. 122) "um 'projeto piloto' da reinvenção do audiovisual brasileiro", a obra foi dirigida por Guel Arraes, já com passado de experiências inovadoras na linguagem na TV, como Armação Ilimitada e TV Pirata. A diferença é que, dessa vez, a estética híbrida com a literatura seria acompanhada por multiplicidade de formatos, primeiro uma minissérie para salas de estar e depois um longa-metragem para as salas de cinema com a distribuição da Columbia Tri Star (EUA).

No início do milênio, a TV por assinatura era restrita, e as locadoras de vídeo tinham papel significativo na distribuição de filmes. Em 2002, eram 8.354 estabelecimentos no país, e o "total de aparelhos de DVD vendidos no país superou o de videocassetes, que entraram em processo de extinção. Em 2003, foram lançados no país 519 novos filmes em fitas VHS e 1.000 títulos em DVD” (SLVA; ET AL, 2013).

A digitalização se alastrava na casa das pessoas, na distribuição e também na produção. O modelo de captação de recursos e as demais fragilidades profissionais tornavam o processo de circulação do filme demorado e mais caro. Na reportagem de Paulo Boccato (2000) na Edição 98 da revista Tela Viva, são colhidos relatos das transformações nas realizações. Na época, câmeras mini-DV de baixa qualidade e preço, na casa dos US\$ 2 mil, já eram utilizadas em filmes como o documentário Buena Vista Social Club (WERNES, 1999) e "Festa de Família (VINTERBERG, 1998). ${ }^{55}$ As câmeras classificadas como profissionais custavam entre US\$ 15 e US\$ 30 mil, já as HD eram restritas aos filmes de diretores como George Lucas. A partir da filmagem, seguiam alterações na edição em programas como Avid ou Final Cult, na captação e por fim até a passagem para película já estava com os dias contados.

Essa faceta da digitalização fortaleceu o papel da arquitetura tecnológica no crescimento das produtoras independentes, e o renascimento de velhos cineastas movimentou o III CBC e a criação do GEDIC com reivindicações traçadas na perspectiva holística dos desafios do audiovisual nacional. Todavia, o resultado final da medida provisória que criou a Ancine em 2001 não foi bem vista pelo grupo por não corresponder principalmente às relações entre cinema e TV.

55 Dirigido por Thomas Vinterberg, o filme Festa em família é marco do movimento do norte europeu "Dogma 95", responsável por produções em custos baixos e sem efeitos especiais. 
Após a eleição de Lula à presidência em outubro de 2002, um seminário, em dezembro do mesmo ano no Rio de Janeiro, redefiniu a agenda a ser colocada na mesa no mandato sob a presença de representação da equipe de transição, juntamente com os integrantes da comissão do Programa de Cultura da campanha de Lula: Hamilton Pereira, Sérgio Mamberti e Antonio Grassi. ${ }^{56}$ A relatoria e a coordenação ficaram a cargo de Orlando Senna (2002), na época, Subsecretário de Audiovisual do Estado do Rio de Janeiro. O documento final criticou, logo no início, os cortes na criação da Ancine que resultaram na incapacidade de regular a competição, bem como ter autonomia financeira e administrativa. No Grupo de Trabalho destinado à televisão, deu-se a participação de pessoas $^{57}$ e principalmente propostas que viriam a pautar os anos seguintes na constituição da rede "Lei da TV Paga":

1. Instalação e operação de uma Rede Pública de Televisão;

2. Imposição de percentuais mínimos obrigatórios de veiculação de produção regional às emissoras;

3. Estabelecimento, por meio de regulamentação, de percentual mínimo de veiculação de produção independente brasileira na grade das emissoras abertas públicas e privadas;

4. Criação de mecanismos de fomento para a produção audiovisual independente, seja originalmente feita para cinema ou para televisão, e que visem a veiculação nas TVs abertas;

5. Retomada das propostas apresentadas pelo GEDIC de inclusão da televisão aberta no âmbito regulatório da ANCINE. As propostas são:

5.1 Cota de Tela: cada emissora de televisão, aberta ou por assinatura, fica obrigada a exibir, em sua programação, um certo número de filmes brasileiros por ano.

5.2 Associação na Produção: cada emissora de televisão aberta ou por assinatura investirá $2 \%$ de seu faturamento em publicidade na coprodução de filmes brasileiros.

5.3. Aquisição de Direitos: cada emissora de televisão aberta ou por assinatura investirá $2 \%$ de seu faturamento em publicidade na aquisição de direitos de exibição de filmes brasileiros.

5.4. Promoção e Publicidade: as emissoras de televisão aberta e por assinatura reservarão parte de seu espaço publicitário à promoção institucional do cinema brasileiro.

6. Estabelecimento, por meio de lei, de garantias de defesa do conteúdo brasileiro e da produção independente brasileira, por questão de soberania nacional. Essa questão ganha maior pertinência com a participação do capital estrangeiro nos meios de reprodução e de difusão (radiodifusão, cabo, satélites, etc.).

7. Estabelecimento de restrições legais à posse acumulada de meios de comunicação de natureza diversa (rádio, TV, mídia impressa, telefonia, provimento de internet, etc.).

56 Grassi também era Secretário de Cultura do Estado do Rio de Janeiro e anfitrião do encontro.

57 Coordenador: Berenice Mendes, membro do Conselho de Comunicação Social. Expositores: Marco Altberg, produtor de televisão; Nelson Hoineff, produtor de televisão; Tereza Trautman, distribuidora de filmes brasileiros para o mercado televisivo; Gabriel Priolli, especialista em mercado televisivo; Mauro Garcia, especialista em televisão pública; Cláudio Mac Dowell, representante da Associação Brasileira de Cineastas. 
8. Criação ou facilitação de mecanismos que permitam a captação de recursos para a televisão pública que não passem necessariamente pelos orçamentos de governos, tais como: flexibilização das restrições da publicidade comercial, fundos de financiamento de TV educativo-cultural, incentivo às inversões privadas na programação educativo-cultural.

9. Facilitação do acesso da população à TV paga, com imposição às operadoras da obrigatoriedade de oferta de pacotes de assinaturas a preços populares, bem como de assinaturas gratuitas para escolas públicas, bibliotecas e instituições similares. (SENNA, 2002)

O documento, na transição, também foi composto pelo GT de Política e Mercado Externo, ${ }^{58} \mathrm{e}$, nesse quesito, o contexto urgia por medidas tão urgentes quanto as nacionais. $\mathrm{Na}$ década de 1990, o cenário internacional se movimenta nos embates protagonizados por França e EUA na Rodada do Uruguai e na formação da Organização Mundial do Comércio (OMC) em relação ao tratamento dos produtos culturais. Isso se deu até chegar ao acordo sobre a "exceção cultural" que viria a sustentar a renovação de medidas protecionistas ao conteúdo audiovisual principalmente na União Europeia.

Após o ciclo de cultura e desenvolvimento, no fim do século XX o fortalecimento da democracia se entrelaça com a necessidade de garantias culturais às minorias historicamente discriminadas, e, ao mesmo tempo, há uma onda de concentração e desregulamentação neoliberal. Isso desemboca na Declaração Universal da Diversidade Cultural (2001). Mas, conforme retoma a ex-Ministra do Ministério das Relações Exteriores (MRE) da Coordenação-Geral de Intercâmbio e Cooperação Esportiva (CGCE), Vera Cíntia Álvarez (2009), o governo do Brasil buscava um suposto equilíbrio de posições em 2001 e chegou a distribuir um comunicado restrito ao audiovisual aos países membros do Conselho para o Comércio em Serviços da OMC com teor liberalizante:

A filosofia da proposta brasileira era a seguinte: dada a situação de fato dos
mercados internacionais do audiovisual, claramente dominados de forma de-
sequilibrada por um só fornecedor (os EUA), a melhor maneira de lidar com
a situação seria recorrer aos próprios mecanismos comerciais para corrigir as
distorções provocadas por essa dominação... A posição defendida pelo Brasil
corresponde à inquietação quanto ao futuro das exportações brasileiras. A
TV Globo exporta novelas para toda a Europa, alguns países de Ásia e da
América Latina e tem difusão a cabo cobrindo todo o continente europeu, os
EUA e o Japão. (SENNA, 2002, p. 267)

58 Coordenador: Jom Tob Azulay, responsável pela política internacional na ANCINE. Expositores: embaixador Samuel Pinheiro Guimarães, economista, ex-diretor administrativo da Embrafilme; embaixador Arnaldo Carrilho, diplomata, especialista em cinema, presidente da Riofilme; Débora Peters, integrante do grupo de trabalho inserção Internacional do Congresso Brasileiro de Cinema; Tarcísio Vidigal, distribuidor internacional; Júlio Wortman, distribuidor internacional (SENNA, 2002). 
Voltando ao documento da transição entre os governos FHC e Lula, as propostas caminhavam para fortalecer a atuação do país devido à ausência de tradição e mercado competitivo internacional, em especial, para a rodada do GATT - Acordo Geral para Comércio de Serviços - com prazo final marcado para março de 2003. O objetivo era buscar "tratamento diferenciado para os produtos audiovisuais, incluídos na categoria "Serviços”, o que, em última instância, poderia redundar na impossibilidade de o Brasil dar continuidade à política de subsídios ao cinema" (SENNA, 2002, p. 10).

Nessa perspectiva, a visão mais crítica sobre as perspectivas nacionais não se resumia ao cinema no período. Os demais elos do audiovisual nacional também passavam por momento delicado, tanto a principal emissora de TV aberta quanto o mercado de TV por assinatura.

\subsection{O MOVIMENTO DE SAÍDA DA GLOBO NA DISTRIBUIÇÃO}

O ano 2001 foi marcado por estagnação na TV por assinatura e pelo aparecimento de sinais de que a Globo não seguiria por muito tempo na distribuição. É certo que, desde a criação da Globosat, havia intenção de prevalecer apenas no conteúdo, entretanto, não há como eximir-se do fato de que muito dinheiro foi investido e, até mesmo, perdido nessa movimentação. Ao mesmo tempo cresceu a autonomia dos programadores e produtores de conteúdo no mercado.

A fim de chegar a pacotes baratos, na casa dos R $\$ 30,00$, a ABTA, em 2002, apontou uma série de gargalos a serem enfrentados. Possebon (2009) enumera oito pontos, e o primeiro deles beira a ironia: fluir o serviço por uma rede única de infraestrutura, conforme os idealizadores da Lei do Cabo almejaram. Todavia, o que mais interessava a eles era partir da proposta de construir um novo modelo de programação: “A preocupação da ABTA era resolver as questões de relacionamento entre programadores e operadores, ajustar o produto da TV paga diante da TV aberta nacional e permitir maior competitividade aos operadores" (POSSEBON, 2011, p. 193).

Na virada do milênio, a importância da TV aberta parecia inabalável no país. Além da pujança da Rede Globo, as demais redes criaram um cenário mais competitivo. A Igreja Universal investia pesado na Record, a Rede TV se espalhava, e tanto o SBT quanto a Band não davam sinais de esgotamento dos seus modelos de conteúdo, seja baseados no entreteni- 
mento infantil e popularesco seja nos esportes e jornalismo. Enquanto isso, a TV paga continuava sem uma identidade singular com o público.

A preparação para um giro empresarial da Globo para fortalecer o conteúdo também foi acompanhada por velhas práticas relacionadas às decisões estatais. Até o fim do século $\mathrm{XX}$, o poderio acumulado por décadas na TV aberta foi transposto à TV por assinatura, tanto que dois conglomerados nacionais, Globo e RBS, continuavam a controlar mais de $70 \%$ do total dos serviços de TV por assinatura nacional, ao lado do grupo Abril (JAMBEIRO, 2011, p. 230). No caso especifico das Organizações Globo, Valério Brittos (2005) aponta que a transnacionalização do capital foi acompanhada por alargamento nos seus negócios alémfronteiras, assim como por parcerias e investimentos em outros elos da cadeia produtiva, com aval dos governantes brasileiros ao ponto de o lançamento da TV Globo Internacional ter sido feito dentro do Palácio do Itamaraty em 1999.

Ao contrário do nascedouro da TV aberta comercial, quando, além da publicidade, a base da infraestrutura e tecnologia foi capitaneada pelo Estado, os recursos para transpor o domínio no espectro para o mais competitivo mercado da TV por assinatura foram próprios das empresas. No caso das Organizações Globo, os investimentos em infraestrutura, tecnologia e conteúdo, mesmo em quadros societários, foi insuficiente frente às ambições, resultando ônus financeiro significativo no início do século XXI para o maior grupo de comunicação de capital nacional ao ponto de declarar default em 2002 (DUARTE, 2005).

$\mathrm{Na}$ época da cadeia produtiva dotada de novos modelos de negócios, a crise financeira se abateu sobre os grupos nacionais de comunicação na virada do século. Sem obter o poderio econômico, a Globo resolveu retroalimentar as velhas armas para os embates regulatórios que viriam a seguir. A primeira arma é a capacidade para a formação de hábitos culturais e posições políticas na sociedade devido à penetração quase total nos lares nacionais, mesmo sem ter os mesmos recursos das teles. A segunda arma é o fato de integrar uma rede de radiodifusores formados por mecanismos clientelistas com o Estado, sendo muitos deles religiosos ou políticos, direta ou indiretamente, em especial, no Congresso Nacional.

No ano de 2002, além do Congresso da ABTA para buscar caminhos à estagnação, foi o último ano dos governos FHC, e duas medidas políticas foram tomadas. O BNDES, sócio no cabo desde 1999, comprou ações da Net Serviços, transação que mobilizou críticas no Congresso e opinião pública, pois o banco seria o principal investidor no plano de reestruturação centrado no cabo. A consequência mais interessante desse negócio é levantada por Possebon (2011): o braço responsável por conteúdos, a Net Brasil, tinha que compartilhar decisões com a Net Serviços, dessa forma, além de questões administrativas e financeiras corriqueiras, 
o BNDES passou a ter poder decisório nas definições da programação. De compras e vendas de produtos a contratos de exclusividade ou parcerias internacionais, tudo passaria pela representação de um banco público.

A segunda medida foi teoricamente mais significativa: os empresários nacionais pressionaram o Congresso e o Executivo a alterar o Art. 222 da Constituição Federal, e, a partir de então, os empreendimentos de imprensa, como jornais, rádios e televisões, receberam permissão para conter até $30 \%$ do capital estrangeiro, numa tentativa de alavancar novos investimentos. Nenhum dos dois movimentos anteriores garantiu a reestruturação da Globo. E seja por falta de fôlego seja por estratégia delineada, o grupo nacional deixa de controlar a Sky no país, a empresa passa a ser da News Corporation. ${ }^{59}$

Não apenas grupos nacionais sentiram a crise no período; a DirecTV, então formada no consórcio liderado pela Hughes (General Motors/EUA) somado a Cisnero (Venezuela), Multivision (México) e TVA (Brasil), ${ }^{60}$ realizara investimentos significativos no país. Para suprir a lacuna deixada pela Globo/Globosat na programação, a DirecTV abriu espaço, em 2001, para a Band entrar como programadora, primeiro com o canal BandNews e depois com o BandSports, obviamente, utilizando a base do conteúdo e estrutura profissional da TV aberta. Ela também mantinha a grade com HBO, ESPN e Disney, mas, não era o suficiente para competir com o consórcio Globo/Net/Sky.

A Abril foi a primeira a não aguentar a disputa com a Sky/Net/Globo, não apenas na infraestrutura ao sair da DirecTV, mas também no conteúdo: vendeu sua participação na ESPN e no canal Bravo!. Até que em 2003, a Sky compra a DirecTv nos EUA, mas, no Brasil, firma acordos com a Organizações Globo para juntos chegarem a 95\% do mercado de DTH no país, e 59\% (32\% Sky) no total da TV por assinatura. Na apuração de Rodrigo Murtinho (2005), o impacto era ainda maior, pois $90 \%$ dos municípios do país só tinham o DTH como tecnologia para TV paga. O mesmo autor sistematiza os pontos firmados com as Organizações Globo para chegar à fusão:

59 LOBATO, Elvira. “Globo perde o controle da TV paga Sky”. Folha de São Paulo. 1 ago. 2002. Disponível em: <http://www.observatoriodaimprensa.com.br/artigos/asp070820024.htm>. Acesso em: 07 jan. 2015.

60 Apesar de as empresas estarem sediadas no país, é difícil mapear todos os seus acionistas, mais ainda, devido à fluidez e demais pontos contratuais que diferenciam poder decisório nas instâncias das empresas. A TVA, por exemplo, é formada em 1996 pela Hearst Corporation, Capital Cities/ABC, Falcon International Communications e Chase Manhattan Bank, além da Abril, detentora de $56 \%$ da empresa na época (MURTINHO, 2005). 
I - Sky não poderia controlar qualquer outro serviço de comunicação, e a Globo só entraria no DTH via Sky, bem como utilizaria o satélite da Sky para distribuir o cabo; ${ }^{61}$

II - Sky mantinha filiação à Net Brasil e os contratos com a Globosat;

III - A Globo teria poder de veto nos conteúdos nacionais;

IV - A Fox não ia investir na internet brasileira;

V - Acesso da Globo aos serviços da News Corp. no exterior.

Outro aviso claro da saída da Globo na distribuição foi a venda das ações da Net Serviços para Telmex (Teléfonos del México) em 2004. A entrada do grupo liderado por Carlos Slim não passou, inicialmente, sob acordos com grupos nacionais, nem empresariais, nem políticos. A vencedora da concessão da Embratel no leilão da Telebrás foi à falência, e o Slim conseguiu ganhar nos EUA os ativos para um consórcio formado por empresas brasileiras e estrangeiras com apoio do BNDES. Três meses depois, comprara 49\% das ações da Net Serviços, porém, segundo Murtinho (2005), uma análise minuciosa do contrato permite afirmar que a Telmex já era controladora real da Net a partir de brechas da Lei do Cabo, o que tornara uma empresa estrangeira majoritária na TV a cabo antes da Lei 12.485/2011.

Já Possebon (2009) não enquadra a causa do negócio como parte do plano de reestruturação da Globopar (Globo Comunicações e Participações), que ainda afundada em dívidas. Não havia especulações ou debate entre os executivos sobre a venda de ações da Net, o que determinou a ação foi um encontro entre Roberto Irineu Marinho e Carlos Slim, sem advogados ou consultorias. O acordo se deu na garantia da Telmex de não concorrer no conteúdo, e esta teria, em contrapartida, o caminho aberto para continuar a faturar com os serviços de telecomunicações (telefonia, banda larga e TV por assinatura).

Nesse período, os exorbitantes lucros das teles não eram mais promessas. O setor fechou 2004 com faturamento bruto de R\$ 99 bilhões, crescimento de 41,6\% no número de usuários e perspectiva ainda maior com o exponencial aumento do poder aquisitivo das classes C e D, expansão da internet banda larga e novos serviços como o de voz por dados, o VOIP. ${ }^{62}$ As teles podiam tanto que ainda em 2000 a Telecom Itália (TIM) investiu no já extingo provedor de internet Globo.com, a fim de tornar-se provedor de conteúdo para os seus clientes na telefonia móvel.

61 A partir de 2004, a News Corp. passaria a ter 72\% do controle da Sky, contra 28\% da Globo.

62 MUNIZ, Ricardo. Revista Exame. Disponível em:

<http://exame.abril.com.br/negocios/noticias/m0076245/>. Acesso em: 7 jan. 2015. 


\subsection{A SINERGIA DA GLOBO}

Se, desde a venda da Net para a Telmex, a temida concentração vertical entre infraestrutura e conteúdo dava sinais de não ganhar ares apocalípticos no país, o desenho do cenário estava longe de ser otimista. ${ }^{63} \mathrm{O}$ problema recorrente da exclusividade na programação seria parcialmente encaminhado na fusão da Sky com a DirecTv e os canais estrangeiros passariam a caminhar sem os conflitos originários dos grupos nacionais (Abril e Globo). Alguns canais caminhariam para formar o pacote básico como Warner, Fox, Cartoon, ao lados dos canais Globosat, e, até mesmo, da TV aberta. Afinal, o acordo Sky/Globo deixa explícito o interesse do grupo nacional em ser um dos protagonistas no fortalecimento da identidade na programação da TV paga. ${ }^{64}$

A articulação dos canais estrangeiros tinha suas próprias razões e já tinha sido exitosa nos primeiros dias da Ancine. A medida veio acompanhada por regulamentação da Condecine no Art. $39^{\circ}$, e, entre as taxas previstas na sua constituição, estava a arrecadação de $11 \%$ das remessas de lucros para o exterior dos programadores, a fim de serem revertidas para o cinema independente nacional. Possebon (2009, p. 198) resgata que as empresas afetadas ameaçavam ir até a Organização Mundial do Comércio (OMC) e retirar os investimentos na TV paga: “A expectativa era que os custos de programação subissem de $25 \%$ a $30 \%$ para fazer frente às obrigações de contribuição que estavam sendo criadas". O ex-diretor geral dos canais Fox no Brasil, Abel Puig, tomou a dianteira das negociações, e, ao fim, as empresas aceitaram repassar 3\% dos lucros obtidos diretamente para coproduções nacionais, sem passar por intermediação do Condecine.

Os grupos estrangeiros explicitaram uma aliança histórica para manter seu predomínio com lógica mais impositiva, parecida com a efetuada por décadas no cinema. Era um sinal de que a Globo precisava se preparar para associações e disputas também com um grupo mais articulado que o do cinema nacional e independente, porém numa postura mais recuada, preocupada em preservar sua fatia no mercado no conteúdo. No momento de reestruturação em

63 O Observatório da Imprensa reproduziu no dia $1^{\circ}$ de janeiro de 2003 o texto apresentado por Venício Lima durante reunião do CCS em junho do mesmo ano. Lima levanta o panorama internacional com a fusão da AOL e Time Warner e a flexibilização das regras de concentração por parte do FCC norte-americano. Já em nível nacional, a tendência de fusões, acrescidas por diversos modelos de concentração (Disponível em: <http://www.observatoriodaimprensa.com.br/artigos/plq010720031.htm>. Acesso em: 07 jan. 2015.

64 A fusão não passou em vão. As denúncias das demais concorrentes na TV por assinatura e até pareceres do CCD resultaram em ações do CADE, fundamentais para atenuar a política de exclusividade na programação. Um Termo de Cessação de Conduta (TCC) foi firmado, pondo fim à exclusividade, mas Sportv e seu payper-view seriam vendidos em conjunto com os demais canais Globosat. 
2002, decidiu ampliar a sinergia entre a TV aberta, fechada, cinema e até internet no portal Globo.com.

O núcleo dirigido por Guel Arraes, mais uma vez, foi responsável por buscar inovações e adequações às demandas da época. A série Brava Gente, iniciada em 2001, colocou no ar episódios de tinta minutos de diversos diretores e produtores independentes. Num desses, Fernando Meirelles e Katia Lund dirigiram Palace II, baseado num capítulo do livro Cidade de Deus do escritor Paulo Lins. O episódio impulsionou a $\mathrm{O} 2$ e a Globo filmes a somarem esforços para a realização do filme Cidade de Deus (2002), com quatro indicações ao Oscar e uma ao Globo de Ouro. Os dois produtores voltaram a se juntar para criar a série Cidade dos Homens (2002-5) com a circulação em sessenta países, bem como o filme Cidade dos Homens (2007).

Na feira Natpe'07 (National Association of Televisin Programming Executives) de 2007, a série Cidade dos Homens foi o produto de destaque, não apenas da Globo, mas de toda a produção nacional presente nas principais redes de TV. Edianez Parente (2007) relatou a dificuldade de o principal produto nacional, as telenovelas, ser incorporado por emissoras internacionais. Além de não desejarem o produto nacional e, sim, ter o direito para fazer adaptações, também não era de interesse a íntegra, e sim recortes dos materiais. Por isso, outras séries e minisséries também foram apresentadas, a exemplo de Carandiru (2005), e Hoje é Dia de Maria (CARVALHO, 2005).

Aliás, desde 2001, a tradição em séries passou a ser mais valorizada a exemplo dos remakes A Grande Família (2001-14), Sítio do Picapau Amarelo (2001-7) e Carga Pesada (2003-7). Novas obras do gênero surgiram: Os Normais (2001-3), Sexo Frágil (2003-4) e A Diarista (2004-7). Já as minisséries, mais fáceis de serem adaptadas para o cinema, mantiveram o vigor com Os Maias (2001), Presença de Anita (2001), A Casa das Sete Mulheres (2003), JK (2006), A Pedra do Reino (2008), Queridos Amigos (2008) e Maysa - Quando Fala o Coração (2009).

Outro conteúdo bem sucedido foi a série 'baianês' Ó Pai Ó (2008-2009), ao selar a associação com núcleos de produção regional, nesse caso, os autores e atores do baiano Bando de Teatro Olodum, além de ser adaptada no formato longa-metragem por meio da Globo Filmes. Era sinal de preocupação da empresa no reconhecimento da regionalização na grade de programação, a fim de evitar o crescimento do debate em torno da regulamentação do Art. 221 da Constituição.

O reality-show Big Brother Brasil (BBB) lançado em 2002 sintetiza alguns vínculos que integram a rede em questão nesta dissertação. A primeira cartada foi antecipar-se ao SBT 
e associar-se a uma produtora independente holandesa, a Endemol, responsável pela patente do $B B B$. Além da TV aberta, o programa passou a ser transmitido parcialmente no Multishow, e integralmente no pay-per-view, internet e rádio Os reality shows também foram responsáveis por remodelar a relação com o público, para além do hibridismo entre as plataformas.

O programa obteve êxito pela ideia repassada de que os integrantes da disputa são pessoas comuns, escolhidas nas diversas regiões do país por suas personalidades, e não por dotes artísticos ou intelectuais. Nessa lógica, qualquer um poderia se tornar uma (sub)celebridade do dia para noite, e sua ascensão dependeria da ligação de telespectador, posto ser ele quem define aqueles que seguem ou saem dos estúdios, por votação. Assim, tudo amplia as fontes de lucros dos exibidores do programa: venda de publicidade nos horários comerciais; merchandising dos equipamentos da casa e os jogos que definem os anjos, líderes e os paredões; e, por fim, a própria ligação pra decidir o futuro dos participantes constitui uma fonte de renda significativa.

Iniciativas como o $B B B$ eram necessárias para um grupo sem hegemonia no conteúdo da TV fechada e crescente ameaça no espectro. No século XXI, a Rede Record mantém o ritmo de crescimento e alcança status ainda maior. A estratégia, iniciada na década de 1990, de disputar audiência com o SBT - tradicional segunda colocada - torna-se exitosa por meio de programas popularescos. Tanto que, paulatinamente, a Record passa a intensificar disputas com a Rede Globo, iniciadas ainda na década de 1990 com troca de acusações e denúncias durante a programação.

A Record utilizou a estratégia de copiar padrões técnico-estéticos com produções para camadas médias, como telenovelas, jornalismo e reality shows, conforme sistematizam César Bolaño e Valérios Brittos (2007). Mas, também tinha suas peculiaridades: fez parceria com a majors Sony no game show Roleta Russa (2003) e, com a produtora nacional e independente Casablanca, colocou no ar a Turma do Gueto (2002-2004) com atores e atrizes negros; apostou no jornalismo local com forte teor policial e assistencialista, como o Balanço Geral ${ }^{65}$ e teve, na apresentadora Ana Maria Braga e num fantoche de papagaio Louro José, uma receita envolvendo culinária, entrevistas e serviços que teve tanto impacto, ${ }^{66}$ ao ponto de

65 O programa Balanço Geral é originário da Bahia, ainda na década de 1980, quando o apresentador, na época, Fernando José, tornou-se prefeito de Salvador. A incidência política deste formato é constatada no Rio de Janeiro, onde o apresentador foi eleito deputado estadual mais votado em 2010, Wagner Montes (PDT) (FERREIRA; ET AL., 2011).

66 "Depois de uma saída tumultuada da Record, na qual chegou a responder por mais de 10\% do faturamento publicitário, ela entra na Globo causando burburinho. 'Muitos atores não se conformam com sua contratação', diz um diretor da emissora. Atacam seu salário, estimado em R \$ 200 mil, e as honras que tem recebido. Acostumada a se virar com mais cinco pessoas na Record, onde começou fazendo de tudo um pouco, na Globo, ela conta com uma equipe de 30 profissionais. A receita que lhe rendeu um patrimônio milionário - seus ganhos mensais chegavam a R\$ 1 milhão na Record - está sendo levada para a Globo. 
a Globo contratá-la em 1999 para ocupar as manhãs tradicionalmente ocupada por programas para o público infanto-juvenil.

A Globo não encontrava facilidades na sinergia em torno do conteúdo e precisava intensificar seu repertório. E foi assim que utilizou parte do mesmo discurso dos presentes no encontro dos cineastas com a equipe de transição de Lula: defesa da cultura nacional. O recurso fora utilizado pela primeira vez na disputa com a DirecTV antes da fusão com a Sky. Sem acesso ao material da Globo, o consórcio integrado pela Abril travou uma disputa para ter acesso à Sportv que se arrastou por anos, e ganhou ares nacionalistas após a Abril vender sua parte em 1999. O CADE teve que intervir e deu ganho de caso à Globo em 2001, ${ }^{67}$ sob mobilização nas esferas institucionais "sensibilizadas" pela ameaça de uma empresa estrangeira cooptar um conteúdo, então, considerado patrimônio nacional. A partir daquele momento, o CADE passou a intermediar constantes disputas sobre o tema, intercedendo a favor de negociações fragmentadas por plataformas, mas, com as fusões e acordos paulatinos entre as operadoras, a briga passou a ser, de forma majoritária, diretamente com os canais da TV por assinatura e, até mesmo, com os assinantes.

A segunda vez foi no "Conteúdo Brasil - Seminário de Valorização da Produção Cultural Brasileira”, em fevereiro do intenso ano de 2004, em parceira com a PUC-SP. A colunista do jornal Folha de São Paulo, Mônica Bergamo (2004), fez um relato da atividade que integrava movimentos para superar a crise sob o lema de "defesa e valorização da produção artística e intelectual brasileira": 68

Num desses movimentos, Marluce Dias da Silva, diretora-geral da Globo, convidou os principais cineastas do país para visitarem a emissora. A TV levou ao ar uma série publicitária com personalidades que vão desde a empresária Milú Villela, presidente do MAM (Museu de Arte Moderna-SP) ao senador Paulo Paim, do PT, todas louvando as realizações da emissora nas áreas cultural e social. Fez ainda uma série de reportagens sobre a cultura brasileira.

Segundo Sérgio D’Antino, 60 anos, advogado da apresentadora, a maior parte de sua verba mensal continuará a vir de merchandising e publicidade, previstos no contrato, com validade até 2003." (BRISSAC, $\begin{array}{lllllll}\text { Chantal. } & \text { Istoé } & \text { Gente. } & 13 & \text { out. } & 1999 . & \text { Disponível }\end{array}$ $<$ http://www.terra.com.br/istoegente/10/reportagens/rep anamaria.htm $>$. Acesso em: $10 \mathrm{jan} .2015$.)

67 A TVA saiu na frente com contratos de exclusividade via ESPN. Rapidamente a Globosat/Globo se juntou à Bandeirantes, reposicionou-se e passou a utilizar a mesma fórmula de restrições em casamento com a TV aberta e apoio do Clube dos Treze. Ainda em 1997, o CADE foi acionado por uma nova associação de operadoras, a NeoTV, por não terem acesso ao canal Sportv, então restrito às associadas à Net. No mesmo ano, o SBT sentiu-se prejudicado na TV aberta por oferecer o maior valor no leilão para o Campeonato Brasileiro da Série A e não vencer. A Fox Sports de Rupert Murdoch, inicialmente, não se estabelece no país para não concorrer com o consórcio Sportv/Globo/Band. A contrapartida da Rede Globo foi ceder os sinais do VHF para a Sky, inclusive das suas filiadas e afiliadas.

68 O seminário foi aberto com palestra de Ariano Suassuna teve entre os presentes Hector Babenco, Cacá Diegues, Luiz Carlos Barreto, Antonio Fagundes, Glória Perez, Marieta Severo e Maria Adelaide Amaral. 
No próprio seminário realizado no Tuca, cineastas lembravam que, em uma de suas conversas com Marluce, nos estúdios da TV, ela foi direta: disse que a emissora fatura, em um ano, o que uma empresa de telefonia celular pode faturar em apenas três meses; e que a emissora é "40 vezes" menor do que a Time-Warner. Uma vez permitido que essas empresas estrangeiras passem a produzir, sem regras rígidas, conteúdo para brasileiros na mídia digital (como TV pela internet, nos próximos anos), a sobrevivência da própria emissora estaria ameaçada. E, junto com ela (calculou a diretora), estaria em risco a sobrevivência dos produtores de cultura nacional. A Globo também está incomodada com a possibilidade de o governo passar a regulamentar fortemente as televisões - cobrando, por exemplo, taxas que seriam destinadas à produção de filmes nacionais. (BÉRGAMO, 2004, s.p.)

Feitos os preparativos, era o momento de resolver as finanças. A venda das ações do cabo para Telmex atenuou a crise, e, por pouco, isso não se concretizou com ajuda estatal. Foi ainda em abril de 2004, que a reportagem de Samuel Possebon na revista Tela Viva, detalhou o programa de empréstimo do BNDES - o Pró Mídia -, não apenas para a Globo, diga-se de passagem. Grandes grupos de mídia nacional enfrentavam déficit que somava R $\$ 10$ bilhões, entre os quais, Abril, Bandeirantes, RBS e Folha de São Paulo. O total anunciado pelo BNDES foi de R \$ 4 bilhões em três linhas de financiamento, entre as quais: recapitalização e pagamento de dívidas num setor tratado como questão de "Estado" para o então ministro chefe da Casa Civil, José Dirceu. O programa não suscitou consensos, a começar nas próprias empresas de comunicação. RedeTV!, Record e SBT saíram da Abert, ao discordar da linha para recapitalização e pagamento de dívidas para ajudar a Rede Globo, então responsável por 80\% do mercado publicitário de televisão.

$\mathrm{Na}$ mesma reportagem, foi demonstrada uma confluência entre as empresas que racharam a Abert, o Fórum Nacional pela Democratização da Comunicação (FNDC) e o pesquisador Murilo Ramos que defendeu aproveitar o momento para rever o modelo regulatório, pois a crise refletia a falta de transparência, concentração e consequente desequilíbrio econômico do setor. Parecia ser essa a hora adequada para puxar uma Lei Geral das Comunicações Eletrônicas, mas o MinC resolveu se antecipar e colocar suas cartas na mesa, ao propor o retorno da Ancinav, e o debate desandou. Por isso, vale contextualizar a atuação do ministério, então comandado por Gilberto Gil. 


\subsection{A II ANCINAV}

Passados os governos FHC, a pauta política central do governos Lula (2002-2005 e sua recondução em 2006-2010) na cultura era revisar a centralidade do mercado herdado desde a Lei Sarney (BRASIL, 1986). Partindo da informação de que, durante os 18 anos da Lei Rouanet (BRASIL, 1991), dos R 8 bilhões investidos em cultura, mais de R 7 bilhões foram originários de recursos público, Albino Rubim (2011) aponta, no novo MinC, uma tentativa de redefinição da capacidade de incidência do Estado, a começar por remontar a estrutura gerencial e ampliar os mecanismos de arrecadação - o percentual do MinC no Orçamento da União passou de $0,2 \%$ para $0,6 \%$ entre 2003 e 2004.

No audiovisual, a Ancine começou subordinada à Casa Civil, e, sob trabalho fluído, em outubro de 2003, é assinado o decreto que a torna vinculada ao MinC junto com o lançamento do Programa Brasileiro de Cinema e Audiovisual. Era a resposta vultosa ao trabalho coordenado por Orlando Senna na Secretaria do Audiovisual. Renata Rocha (2014) resgata que a primeira ação do Secretário foi extinguir o canal por assinatura TV Cultura e Arte. Responsável por quase um terço do orçamento da Secretaria, o canal era exibido pela TV Escola e nas operadoras Sky, Tecsat, e Directv. E, no seu lugar, iniciaram-se as formulações para um emissora pública de TV e políticas públicas, a começar pelo DocTV no primeiro semestre de 2003:69

Desenvolvido em parceria com a TV Cultura e a Associação Brasileira das Emissoras Públicas, Educativas e Culturais (Abepec), o programa se revela uma iniciativa pioneira de fomento à parceria entre a TV pública e a produção independente. Sua constituição toma como base a experiência do Núcleo de Documentários da TV Cultura. (ROCHA, 2014, p. 123)

O problema maior para aqueles envolvidos nas políticas para o audiovisual, ao assumirem o governo em 2003, foi o crescimento de uma nova bolha estimulada pela Lei do Audiovisual (BRASIL, 1993), e, assim, os trinta filmes nacionais lançados chegaram ao recorde histórico de 22\% no market share, o que representou 22.291 .806 espectadores.

No seu Art. $3^{\circ}$, a Lei prevê que a contribuição no imposto de renda oriunda das atividades envolvendo o audiovisual em qualquer plataforma pode receber abatimento de $70 \%$,

69 Renata Rocha (2014) sistematiza as ações desencadeadas pelos DocTV. Em quatro temporadas, foram 3.000 projetos e 170 selecionados. A partir de 2006, articula-se internacionalmente no DocTV América Latina, desenvolvido no âmbito da Conferência de Autoridades Cinematográficas Íbero-americanas (CACI), que congrega a maioria dos países latino-americanos, além de Portugal e Espanha. Após a criação da TV Brasil, em 2007, o projeto cresce ainda mais, e, no ano de 2009, é lançado o DocTV CPLP, que reúne os países membros da Comunidade de Países de Língua Portuguesa (Angola, Brasil, Cabo Verde, Guiné-Bissau, Moçambique, Portugal, São Tomé e Príncipe, Timor-Leste e Macau). 
caso repasse o mesmo valor abatido em novas obras sob sua propriedade intelectual. Nos primeiros dez anos, as empresas internacionais utilizaram pouco esse dispositivo, porque acarretava problemas na Receita dos EUA, pois o abatimento no Brasil continuava a contar nas remessas de lucro, ainda assim, a Columbia foi exceção e investiu em filmes como Tieta do Agreste (DIEGUES, 1996), Guerra de Canudos (REZENDE, 1997) e O Que É Isso, Companheiro? (BARRETO, 1997) (IKEDA, 2011 apud IKEDA, 2010). Isso, até o governo editar a MP 2228 -1/01 responsável por criar a Ancine. No Art. 39, a medida passou a taxar as empresas internacionais em mais de $11 \%$ nas remessas de lucro para exterior, a não ser que utilizassem o Art. $3^{\circ}$ da Lei do Audiovisual. Só a partir de então, ficou mais vantajoso utilizar o dispositivo. E foi, dessa maneira, que a Globo Filmes se associou às empresas estrangeiras nas seis obras mais assistidas naquele ano, conforme tabela a seguir:

Tabela 1 - Filmes coproduzidos pela GloboFilmes em 2003

\begin{tabular}{lll}
\hline Filme & Empresa Internacional & Espectadores \\
\hline Carandiru & Columbia & 4.693 .853 \\
Lisbela e o Prisioneiro & FOX & 3.174 .643 \\
\hline Maria, Mãe do Filho de Deus & Columbia & 2.332 .873 \\
Xuxa Abracadabra & Warner & 2.214 .481 \\
Didi, O Cupido Trapalhão & Columbia & 1.758 .579 \\
Deus é Brasileiro & Columbia & $635.212,00$ \\
\hline
\end{tabular}

Fonte: IKEDA, 2011, com adaptações.

A maior relação das equipes de produção nacionais com o mercado estrangeiro propiciou um maior conhecimento de mercado e técnico nesse período, todavia, Marcelo Ikeda (2011, p. 81) aponta os problemas a média e longo prazo:

\begin{abstract}
No entanto, o mecanismo apresenta algumas desvantagens. De um lado, o mecanismo aprofunda a dependência do filme brasileiro de grande bilheteria à estratégia de distribuição formulada por uma distribuidora estrangeira, cujo produto principal é por definição o filme estrangeiro, oriundo de sua matriz. De outro lado, como as principais beneficiárias do mecanismo são as distribuidoras estrangeiras (majors), as distribuidoras brasileiras aumentam suas dificuldades em obter um filme brasileiro de maior potencial comercial, acirrando sua desvantagem competitiva em relação às majors. Além disso, como as distribuidoras tornam - se coprodutoras das obras incentivadas, o mecanismo reduz os direitos patrimoniais das empresas produtoras brasileiras, dificultando a capitalização d essas empresas.
\end{abstract}

Os problemas elencados acima não representavam os anseios do MinC. Por isso, o fortalecimento da Secretaria do Audiovisual com o DocTV foi acompanhado de ousada tentativa de substituir a incipiente Ancine pela Ancinav na primeira gestão de Lula. E, dessa forma, ampliar a capacidade de regulação, fiscalização e fomento do Estado. A minuta do anteprojeto 
vazou na imprensa antes de ser colocada para consulta pública, e segue o resumo dos pontos considerados chave neste trabalho.

O documento inicial desta Ancinav utilizava uma visão ampliada do audiovisual no Art. 37: "Atividade cinematográfica e audiovisual designa o conjunto de ações e atividades que compõem a oferta de obras cinematográficas e de outros conteúdos audiovisuais a usuário ou grupo de usuários, determinável ou não". E, dessa forma, pretendia, no Art. 47, atuar sobre "serviços de telecomunicações que tenham o conteúdo audiovisual como parte inerente ao serviço, incluindo o serviço de radiodifusão" .

No caso das telecomunicações, a proposta pretendia chegar no Cabo, DTH, MMDS e TVA. A ideia era que todas essas atividades relacionadas ao conteúdo ficassem a cargo do Conselho Superior de Cinema e Ancinav, retirando poderes da Anatel, do Conselho de Comunicação Social (CCS) e do Minicom. Para isso, tinha como referência regulatória para liberdade de expressão o Capítulo V da Constituição Federal nos artigos 221, 222, 223 e 224. Os princípios fundamentais eram orientados a fim de "garantir o desenvolvimento" e "proteger os valores éticos e sociais da pessoa e da família” inclusive em material jornalístico.

Quanto ao mecanismos de estímulo ao conteúdo nacional, entre os Art. 91 e 95, foram levantadas genericamente obrigações aos distribuidores de home-video, exibidoras de cinema e prestadores de serviços de telecomunicações e radiodifusão. No caso da radiodifusão, ficaria obrigado a estabelecer um "compromisso público a ser firmado com a Ancinav e MinC" para exibição de obras brasileiras, independentes, regionais e até mesmo para o público infantil. Já as prestadoras de serviço de TV por assinatura ficaram obrigadas a oferecer canais de programação majoritariamente compostos por obras cinematográficas e audiovisuais brasileiras de produção independente.

Quanto ao recolhimento da Condecine, todas as atividades seriam taxadas balizadas nas suas especificidades, inclusive a publicidade, e, no caso, só programadores estrangeiros de TV por assinatura seriam abonados, caso elevassem o percentual destinado à coprodução de $3 \%$ para $6 \%$. Por sinal, a Ancinav ficaria definitivamente responsável por intermediar os direitos autorais nas obras audiovisuais. A arrecadação dessas operações seria destinada a fundos de financiamento e respectivas linhas de atuação da agência, que, por sua vez, teriam seus direitos patrimoniais repassados às emissoras públicas após oito anos.

A intenção era a melhor possível: responder às demandas do III $\mathrm{CBC}$, do documento de transição e do Seminário da PUC-SP com uma unidade regulatória para o audiovisual, incluindo a televisão aberta. Mas, suscitou uma onda de críticas sobre uma possível tendência de dirigismo cultural e cerceamento da liberdade de expressão e artística por parte dos gran- 
des grupos de mídia do país, e, ao mesmo tempo, novas cisões nos independentes e até mesmo críticas abertas do campo em defesa do direito à comunicação. O MinC tentou contornar o problema, abriu consulta pública, divulgou novas minutas e retirou a radiodifusão do projeto. Foi em vão. O vice-presidente das Organizações Globo, João Roberto Marinho, não se intimidou devido ao momento de crise financeira e escreveu artigo na Folha de São Paulo:

\begin{abstract}
A ameaça da volta da censura, que era real, dissipou-se com a supressão de diversos artigos, o que só merece aplausos. Mas, ao afastarem o perigo de censura, os formuladores da Ancinav têm deixado ainda mais claro que pretendem autoritariamente intervir naquilo que está dando certo, seja em cinema, seja em televisão. A intenção, dizem, é proteger a indústria nacional, mas o resultado será o oposto. Equivocadamente, esses formuladores acreditam que o nosso modelo de produção é único no mundo, quando, na verdade, ele é o único que pode tornar nossa indústria competitiva. (MARINHO, 2004)
\end{abstract}

Relator do primeiro projeto da Ancinav no Gedic, o diretor Cacá Diegues teceu críticas duras no Jornal Nacional do dia 14 de setembro de 2004: "Nós estamos passando um cheque em branco pra qualquer governante que venha no futuro. Se nós não esclarecermos que limitações, que restrições são essas, estamos passando cheque em branco para o futuro".

E, por fim, o então coordenador executivo do Instituto de Estudos e Projetos em Comunicação e Cultura (INDECS), Gustavo Gindre, ${ }^{70}$ enviou carta ao MinC, criticando o fato de estar descolada de Lei Geral, qualificando o processo de construção como "desastroso", rechaçando a divisão entre cinema e audiovisual, e considerando o modelo de agência despolitizador por separar aspectos "técnicos" e "políticos".

À frente do projeto da Ancinav estava o ministro Gilberto Gil, com uma carreira artística de diálogos perene com grupos hegemônicos das indústrias culturais, e, ao mesmo tempo, vinculado a produtos e movimentos artísticos, por diversas vezes, relacionados direta ou indiretamente a contextos políticos contestatórios da hegemonia, ao ponto de ser preso e exilado durante a ditadura militar. Todavia, o papel de articulação e formulação da Ancinav tem a presença de Orlando Senna como determinante. Após a passagem por Los Banõs, Dragão do Mar e governo do Rio de Janeiro, Senna teve ao lado nomes como Manoel Rangel, Leopoldo Nunes, Paulo Alcoforado, Debora Peters, Alfredo Manevy, Mário Borgneth, Mário Diamante, Sérgio Sá Leitão, Alex Patêz e Mauricio Hirata, que seriam gestores do MinC e da Ancine durante os governos Lula, e alguns deles seguiram no primeiro governo Dilma (2011-2014).

70 Lista Cinema do Brasil. Disponível em: $<$ http://www.cinemabrazil.com.br/pipermail/cinemabrasil/2004September/006595.html >. Acesso em: 11 jan. 2014. 
Dessa feita, o conjunto de gestores trouxe à tona os desafios na Ancinav e seguiu na atuação a fim de criar instrumentos para o desenvolvimento do audiovisual, haja vista a Convenção sobre a Proteção e a Promoção da Diversidade das Expressões Culturais; a criação do Fundo Setorial do Audiovisual (FSA); e o Fórum de TVs Pública - basilar na criação da Empresa Brasil de Comunicação (EBC). Por último, o MinC também tentou intervir no decreto que instituiu o Sistema Brasileiro de Televisão Digital Terrestre (SBTVD-T), dessa vez, sem trazer os resultados esperados.

\subsection{A CONVENÇÃO DA DIVERSIDADE}

A posição liberalizante do Itamaraty quanto ao audiovisual em 2001 foi revista na construção da Convenção a partir de 2003 na atuação conjunta do MinC e do Ministério das Relações Exteriores, conforme resgata Giuliana Kauark (2012). A autora contextualiza o audiovisual nos embates entre França e EUA, até desaguar na tese de "exceção cultural" na Rodada do Uruguai (1986-1993), no Relatório Nossa Diversidade Criadora (1996) e na declaração para a Diversidade Cultural (2001). Ainda assim, havia fragilidade regulatória. Dessa forma, no ano de 2003, ministros de dezesseis países entregaram, na Unesco, o desejo de criar uma Convenção: "Os ministros queriam um instrumento normativo, que criasse direitos e obrigações para os Estados, e legitimasse o direito de preservar ou criar políticas culturais nacionais para sustentar a produção e a circulação de conteúdos culturais" (KAURAK, 2012, p. 82).

No mesmo ano, a $32^{\circ}$ Conferência Geral da UNESCO votou por unanimidade por desenvolver o instrumento, e, a partir de então, o Brasil teria uma papel estratégico ao aglutinar países em desenvolvimento nos embates contra a posição liderada pelos EUA, que, por sua vez, retornava à UNESCO desde os conflitos em torno do Relatório MacBride em 1984. Dois anos depois, em 2005, a Convenção foi aprovada com 148 votos a favor, dois contra (dos EUA e Israel) e quatro abstenções (da Austrália, Honduras, Nicarágua e Libéria). O Brasil ratificou o documento em março de 2007, após passar no Congresso Nacional e Presidência da República. E seguiu à frente no processo de implementação ao criar a Secretaria da Identidade e da Diversidade (2007); sediando, no mesmo ano, o "Seminário Internacional sobre Diversidade Cultural: práticas e perspectivas"; e a posterior eleição para o Comitê Intergovernamental (2008) previsto na Convenção. 
A partir de então, o governo brasileiro teria mais um instrumento para enfrentar programadores internacionais, caso ameaçassem procurar a OMC para impedir medidas de proteção e estímulo ao audiovisual nacional, conforme tinha ocorrido na criação da Ancine.

\subsection{O FUNDO SETORIAL DO AUDIOVISUAL}

A vinculação da Ancine ao MinC não significou subordinação ou mesmo sincronia política imediata. Por ser um agência reguladora, ela é administrada por uma diretoria colegiada aprovada pelo Senado e composta por um diretor-presidente e três diretores, todos com mandatos fixos. Somente em dezembro 2006, chegou ao fim o mandato do primeiro diretorpresidente Gustavo Dahl, e, logo depois, assumiria o posto Manoel Rangel. Apesar de formarse no curso de audiovisual na USP e de ter dirigido curtas-metragens, a distinção na trajetória de Rangel está relacionada ao seu vínculo orgânico com o PCdoB, desde o ensino secundário.

No governo Lula, Rangel foi assessor especial do MinC (2004-2005) e, nesse período, chegou a ser substituto de Orlando Senna na Sav, quando coordenou o grupo de trabalho sobre regulação e reorganização institucional da atividade cinematográfica e audiovisual. Foi então que seguiu para a Diretoria Colegiada da Ancine (2005) e, um ano depois, à presidência do mesmo órgão. O ato que marca o início da sua gestão é a Lei 11.437/2006 (BRASIL, 2006) responsável por criar o Fundo Setorial do Audiovisual (FSA), vinculado ao Fundo Nacional de Cultura (FNC).

Até então, os recursos investidos no setor com a intermediação estatal eram estritamente oriundos dos mecanismos de renúncias fiscal. A Lei 11.437 (BRASIL, 2006) não acabou com essas fontes, ao contrário, prorrogou o prazo de vigência e intensificou suas ações (IKEDA, 2011). Só que, dessa vez, os recursos captados na atividade audiovisual, via Condecine, foram destinados integralmente ao FSA.

Apesar do FSA estar alocado no Tesouro da União e ficar propenso à "captura" por parte do governo, a seleção dos projetos passa por um Comitê Gestor com atuação orientada por critérios de mercado e diversidade cultural integrado por: dois representantes do MinC, um da ANCINE, um dos agentes financeiros credenciados e por dois membros do setor audiovisual, designados para mandato de dois anos, a partir de lista tríplice nominal encaminhada pelo Conselho Superior de Cinema. O Comitê, por sua vez, seleciona diretamente os beneficiários sem ater-se a fundo perdido nas seguintes modalidades: 
- Investimento - Participação em projetos, tendo como contrapartida a participação do FSA nos resultados comerciais dos mesmos, e no capital de empresas (participação minoritária). Nessa modalidade de colaboração financeira, os recursos aplicados pelo FSA são retornáveis, porém não exigíveis.

- Financiamento - Operações de empréstimo a projetos, mediante a constituição de garantias e tendo como contrapartida o pagamento de encargos financeiros, com plena exigibilidade dos recursos;

- Equalização - Redução de encargos financeiros incidentes em operações de financiamento;

- Valores não-reembolsáveis - Modalidade de colaboração financeira prevista apenas em casos excepcionais, mediante a prévia aprovação do CGFSA. $(\text { FSA, 2014) })^{71}$

A modalidade "Investimento" passa a ser predominante, e, nesse caso, a Ancine pode receber os recursos alocados caso a obra dê o retorno financeiro estipulado; no "Financiamento", os juros ficam a valores abaixo de mercado, e podem ser abatidos com a "Equalização". Por fim, os casos “não-reembolsáveis" são excepcionais.

E, assim, a Ancine encaminhava um mecanismo a fim de ampliar sua capacidade de influência no mercado, mais ainda, se os aportes ao FSA aumentassem, como de fato veio a ocorrer com a Lei da TV por Assinatura.

\subsection{A TV PÚBLICA NACIONAL}

Passada a aprovação do FSA, a participação na construção de TV Pública nacional foi mais um passo do MinC para institucionalizar demandas da produção independente. Inicialmente, o presidente Lula delegou ao ministro das comunicações, Hélio Costa, o papel de coordenar o processo. Rapidamente, a iniciativa foi alvo de críticas do campo público devido ao histórico do ministro com o setor comercial. Sem avançar na pasta, o projeto contou com a mobilização da sociedade civil e gestores das emissoras públicas no I Fórum Nacional de TVs Públicas, no mês de maio de 2007, sob co-organização da Secretaria de Comunicação Social da Presidência da República (Secom-PR) e o MinC. Foi produzida uma carta, ao final, assinada por associações comunitárias, universitárias, educativas e culturais, e, a partir de então, a coordenação do GT para a criação da TV Pública Nacional ficou a cargo da Secom-PR.

Nesse momento, os problemas para o desenvolvimento do projeto seriam tanto externos quanto internos. Os externos foram explicitados na imprensa e na oposição no Congresso Nacional até a aprovação da Lei 11.652, sancionada pelo presidente Lula no dia 7 de abril de

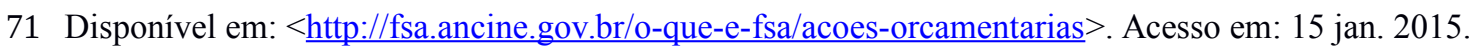


2008. Ainda assim, a Lei criou a TV Brasil a partir da fusão da Radiobrás e da Associação de Comunicação Educativa Roquette Pinto (Acerp), e estabeleceu como fonte de arrecadação a Contribuição para o Fomento da Radiodifusão Pública oriunda da operação dos serviços de telecomunicações e radiodifusão, bem como, definiu reserva de espaço significativo da programação à produção independente no Art. $8^{\circ}$ : "IX - garantir os mínimos de 10\% (dez por cento) de conteúdo regional e de 5\% (cinco por cento) de conteúdo independente em sua programação semanal, em programas a serem veiculados no horário compreendido entre 6 (seis) e 24 (vinte e quatro) horas" (BRASIL, 2008).

Superada essa fase, a montagem começou com a escolha da jornalista Tereza Cruvinel para a presidência da EBC, por indicação do então ministro da Secom-PR, Franklin Martins. A partir de então, os conflitos se exacerbaram entre o MinC e a Secom-PR e foram muito além das divergências com a primeira presidenta da EBC. Renata Rocha (2014, p. 107) analisa, com base em entrevistas, a relação "ambígua" entre os dois ministérios:

A extensa agenda em comum torna frequentes, tanto o diálogo como os impasses entre o MinC e este órgão, que possui status de ministério. Cabe destacar, como um primeiro exemplo, a interferência do Ministério da Cultura na polêmica acerca da definição das diretrizes pela Secom-PR para o patrocínio de projetos culturais, ainda no primeiro semestre de 2003.

Na montagem da Lei, a EBC ficou na alçada da Secom-PR. As divergências continuaram até chegar ao estopim na definição de recursos orçamentários. Mario Borgneth, diretor de relacionamento e rede, articulou a captação para financiar a produção independente. Cruvinel discordou, alegando que o momento era para investir no parque tecnológico da empresa. Borgneth saiu, e, logo depois, o diretor-geral, Orlando Senna. Ficou a ideia de investir numa TV pública integrada à produção nacional independente e regional, sob diversidade de formatos e linguagens.

\subsection{A DIGITALIZAÇÃO ANALÓGICA}

As políticas para o audiovisual confluíram as tentativas do Minc adentrar por áreas tradicionalmente do Minicom. São diversas linguagens, gêneros e segmentos profissionais que têm, no cinema e na televisão, o símbolo de duas plataformas e processos irmãos que teimavam em caminhar separados na regulação. É certo que parte desses entraves se explica por distinções históricas na cultura profissional e nos arranjos empresariais. Mas, essas barreiras 
foram, paulatinamente, abrandadas, enquanto as políticas continuavam defasadas. Por isso, era natural que o MinC tentasse participar na elaboração do modelo brasileiro de televisão digital. Entretanto, a responsabilidade estava na alçada do MiniCom, e, nessa pasta, Gilberto Gil não teve espaço para dialogar desde o começo do governo, independentemente do ministro:

Com a Comunicação foi sempre muito difícil porque eu acho que não percebi em nenhum momento um maior entusiasmo da gestão do Ministério das Comunicações com a pauta cultural, com a pauta que nós pudéssemos apresentar para além do que eles já conseguiam perceber como função cultural das comunicações. Então, é um Ministério que estava muito assentado, e ainda hoje está assentado numa visão funcional dos meios de comunicação que temos hoje no país. Enfim, que estão sob a gestão, pelo menos a observação institucional e a gestão deles. Todo deslocamento que propúnhamos para a democratização das comunicações, rádios comunitárias, televisão pública, TVs comunitárias, todas essas coisas, não me pareceu que tenham realmente entusiasmado o Ministério das Comunicações, pelo contrário. (GIL, 2008, p. 195 apud ROCHA, 2014, p. 107)

O debate da digitalização era longo, e, conforme o resgate de César Bolaño e Valério Brittos (2007), institucionalizou-se desde 1991 no governo Collor. Passou, no governo Itamar, por grupo de trabalho com a Abert e a Sociedade de Engenharia de Televisão (Set). Depois, a Anatel surgiu em 1997 e assumiu o processo, mas manteve a força dos radiodifusores nos processos de testes. Foi então que os fabricantes de equipamentos estrangeiros iniciaram um processo de lobby, envolvendo instâncias multilaterais e bilaterais do próprio Japão, EUA e União Europeia.

A questão foi repassada para o governo Lula, e, nos primeiros anos de mandato, ainda sob crise financeira nas grandes empresas de mídia do país, os ministros das comunicações Miro Teixeira e Eunício de Oliveira chegaram a conversar com a China para realizar uma parceria, e desenvolveram um projeto de tecnologia nacional permeada por valorização da diversidade e inclusão social, chegando até a prospectar utilização da TV digital para ampliar o acesso à internet gratuito, devido à capacidade de bidirecionalidade e consequente incorporação de outros serviços de telecomunicações.

Até que a crise mudou de lado, saiu da Globo e foi parar dentro do governo federal. Denúncias de corrupção desde 2004 instauraram uma crise política, responsável por derrubar figuras estratégicas como o então ministro chefe da Casa Civil, José Dirceu. No mês de julho de 2005, assumia o MiniCom Hélio Costa, ex-jornalista da Rede Globo, e concessionário de rádio FM no interior de Minas Gerais. Era uma forma de construir pontes com a empresa da família Marinho após os embates na Ancinav e o entrave na Pró-Mídia do BNDES. 
O ministro resolveu escantear o desenvolvimento de tecnologia nacional, e recomendou-se o modelo japonês, com as justificativas técnicas de ser mais adequado às plataformas móveis, mais imunidade a ruídos, e mais satisfatório para qualificar e replicar o sinal da radiodifusão, bem como para permitir a adoção da alta definição. E, assim, foi assinado pela presidência o decreto $\mathrm{n}^{\mathrm{o}}$ 5.820, de 29 de Junho 2006, disposto sobre a implantação do SBTVD-T. Na gênese, o decreto mantém o modelo construído com o CBT de 1962, sem modificações significativas na cadeia de valor ou mesmo legislativas. No Art. $6^{\circ}$ elencou três possibilidades de serviços:

I - transmissão digital em alta definição (HDTV);

II - transmissão digital simultânea para recepção fixa, móvel e portátil; e

III - interatividade.

Ficou de fora a possibilidade de realizar multiprogramação, bem como, quaisquer necessidades de revisar a destinação do espectro ratificado no Art. $7^{\circ}$, ao consignar às concessionárias em vigência o canal com largura de banda de seis mega-hertz. Ou seja, as empresas continuariam a explorar continuamente a outorga até o apagão analógico.

A novidade maior foi o Art. $13^{\circ}$, ao reservar à União a exploração de quatro canais com finalidades públicas: Canal do Poder Executivo; Canal de Educação; Canal de Cultura; e, por fim, o Canal de Cidadania. Tentou-se, dessa forma, sincronizar os canais abertos a princípios estabelecidos apenas na Lei do Cabo, e, assim, estimular a formação de campo público de TV.

Durante a implementação, as deficiências do decreto se tornaram mais latentes. A decisão de ser opção de cada empresa o investimento na arquitetura tecnológica digital favoreceu majoritariamente a Globo e a Record, únicas com capacidade de alocar altos recursos rapidamente. Também não foi à frente o Ginga, um software aparelho desenvolvido por universidades nacionais responsável por interatividade; bem como o set-top box previsto para traduzir as televisões não compatíveis com o sinal digital devido aos preços muitos caros.

O set-top também foi cogitado para levar à TV por assinatura a alta definição dos canais abertos, pois a digitalização os dotou de potencial na qualidade de imagem superior aos serviços de cabo ou satélite. Sem emplacar o set-top ou mesmo universalizar aparelhos de TV aptos a captar o sinal aberto em HDTV, a TV paga se tornou um bom atrativo para acessar os canais mais comuns ao público com uma boa imagem. Mais ainda, a lentidão da digitalização 
da TV aberta no país permitiu tempo suficiente para os canais pagos mais assistidos passarem também à alta definição.

\subsection{AS ASSOCIAÇÕES DOS INDEPENDENTES}

O Congresso Nacional formula, debate, veta ou aprova leis relativas à comunicação e à cultura. Ainda assim, uma característica marcante deste Poder a partir da promulgação da Constituição Federal está na ausência de regulamentação do Capítulo V, relativo à Comunicação Social da Carta Magna, bem como, o tempo de inatividade do seu órgão auxiliar, o Conselho de Comunicação Social (CCS).

No caso do audiovisual, todos os cinco artigos do Capítulo V (Art. 220 a 224) impactam suas atividades, tendo o Art. 221 o debate de regulamentação mais recorrente na constituição histórica da rede aqui descrita:

\footnotetext{
Art. 221. A produção e a programação das emissoras de rádio e televisão atenderão aos seguintes princípios:

I - preferência a finalidades educativas, artísticas, culturais e informativas;

II - promoção da cultura nacional e regional e estímulo à produção independente que objetive sua divulgação;

III - regionalização da produção cultural, artística e jornalística, conforme percentuais estabelecidos em lei;

IV - respeito aos valores éticos e sociais da pessoa e da família. (BRASIL, 1988)
}

A tentativa de regulamentação tem como ícone o trabalho da deputada federal Jandira Feghali (PCdoB-RJ) desde 1991. No Seminário realizado no Rio de Janeiro na transição entre os governos FHC e Lula, a aprovação da iniciativa liderada pela deputada fluminense foi tratada como tema urgente. Na segunda proposta da Ancinav, tentou-se aplicar uma regulação envolvendo a televisão aberta em correspondência aos quatro incisos do Artigo 221 da CF. Essa proposta foi objeto de críticas resgatadas neste trabalho por, supostamente, criar dificuldades no desenvolvimento econômico das comunicações e, ao mesmo tempo, estimular a censura.

Em torno da regulamentação, houve envolvimento do grupo audiovisual nacional e independente, articulado no objetivo de obter garantias para distribuir o conteúdo produzido principalmente na TV aberta. Porém, após as divergências no processo da Ancinav, houve 
uma reconfiguração na organização do grupo, e a unidade foi transmutada por uma ruptura: "De um lado, o CBC e seu apoio ao Ministério da Cultura e ao anteprojeto de criação da Ancinav; de outro, um pequeno, mas importante grupo de produtores, distribuidores e exibidores, capitaneados pelo cineasta Roberto Farias, porta-voz da instituição" (GOMIDE, 2011, p. 160).

A instituição referida é o Fórum do Audiovisual e do Cinema (FAC), criado em novembro de 2004. Além de Roberto Farias, antigo diretor da Embrafilme, o Fórum foi formado por representantes da publicidade, TV por assinatura, vídeo locadoras, radiodifusão e propaganda. ${ }^{72}$ Independentemente da fragilidade desse Fórum na incidência dos processos regulatórios, sua importância está ao simbolizar associações mais fluídas dos antigos cineastas com os demais membros do audiovisual.

Um dos elementos que motivaram o aumento nas associações é tecnoestético, pois houve um aprofundamento na interação da digitalização com o processo de circulação:

Antes da transformação tecnológica, o que afastava o produtor independente
da TV? Ela detinha os equipamentos, e o produtor independente era associa-
do porque levava propostas de conteúdo para fazer dentro da emissora. Hoje
a tecnologia está acessível ao produtor. Ele usa a câmera $4 \mathrm{~K}$, e faz às vezes
até melhor. Para a TV se tornou complicado remontar o parque tecnológico a
todo momento. Algumas emissoras como Band e CNT passavam uma cartela
dizendo que era produtor independente, e era de má qualidade. Hoje é até su-
perior. No caso dos canais de tv por assinatura, eles não têm estrutura no
Brasil, só tem departamento de marketing, E hoje a produção brasileira é
comparável ao que tem no exterior. Qualidade tecnológica associada à quali-
dade de produção. As novas séries brasileiras têm trabalho apurado de rotei-
ro, dramaturgia, elenco... Os custos da produção brasileira ainda são mais al-
tos, mas estamos na tendência mundial de valorizar as séries. (GARCIA,
2014, informação oral)

Em nível institucional, também foram normatizados mecanismos para estimular a associação da produção brasileira com a distribuição. O Art. 39, inciso X, da Medida Provisória que criou a Ancine é exemplo na aprendizagem de expertise do setor. O artigo determina que o redirecionamento de $3 \%$ do volume de remessas de lucros para o exterior em coproduções com empresas nacionais exonera a necessidade de pagar a taxa de $11 \%$ dessas remessas ao Condecine. No computo geral, o dispositivo representou 5,3\% dos valores captados por meio de renúncia fiscal entre os anos de 1994 e 2008. Porém, ele passou a ser mais utilizado diretamente pela estadunidense Home Box Office (HBO), e, em termos de qualidade, as séries en-

72 Os membros da primeira formação do Fórum foram: Alexandre Annenberg (ABTA), Rodrigo Guimarães Saturnino Braga (Sindicato das Empresas Distribuidoras do Estado de São Paulo), Carlos Eduardo Rodrigues (Abert), Wilson Alves Feitosa (UVB), Abrahão Sochaczewskim (Abele), Luis Severiano Ribeiro (Abracine), Roberto Figueira de Farias (Sicav), André Guilherme Marques Porto Alegre (Associação dos Profissionais da Propaganda), Marisa Leão Salles de Rezende (Sicav/RJ), Marcelo Bertini (Abraplex) e Roberto Franco Moreira (Siaesp) (GOMIDE, 2011). 
tão produzidas buscaram um padrão compatível aos conteúdos exibidos nos canais HBO. No entanto, segundo Ikeda (2012, p. 113), essas produções não continuaram devido aos altos custos nos treze episódios que compõem cada série. Veja-se, a seguir, a Tabela 2 que sintetiza os custos de produção e as parcerias realizadas.

Tabela 2 - Séries coproduzidas pela HBO Brasil

\begin{tabular}{|lll|}
\hline Série/ano & Produtora brasileira & Captação via Art. 39 X \\
\hline Mandrake (2005) & Conspiração Filmes & R\$ 11 milhões \\
Filhos do Carnaval (2006) & O2 Produções & R\$ 14,5 milhões \\
\hline Alice (2008) & Gullane Entretenimento & R\$ 13 milhões \\
\hline & Fonte: Ancine, 2011, com adaptações. & \\
\hline
\end{tabular}

Apesar do conteúdo formatado para TV por assinatura permitir novas formas de associação, os longas-metragens continuam a ser a maior expressão da relação do audiovisual independente com os demais segmentos da cadeia. Nesse sentido, no Brasil, assentado nas leis de incentivo, centenas de produtoras conseguiram finalizar um longa-metragem a partir da década de 1990. Levantamento da Ancine feito entre 1995 e 2009 aponta que 320 produtoras conseguiram alcançar o almejado filme em longa-metragem, todavia, 2/3 das produções se resumiram a apenas um filme por produtora:

\footnotetext{
Desse modo, resulta claro que o modelo de leis de incentivo, privilegiando uma política de realização de projetos isolados e não de fortalecimento das empresas produtoras, não conseguiu estabelecer um ritmo industrial ao mercado de produção, frágil pela sua extrema pulverização. (IKEDA, 2012, p. 139)
}

A fragilidade se torna ainda mais grave, se levarmos em consideração as disparidades regionais. As produtoras dos estados do Rio de Janeiro e São Paulo, juntas, obtiveram 92,77\% de todos os recursos captados na Ancine entre 1995 e 2012. E, mesmo as obras reconhecidas por diretores ou imaginários de outras regiões do país, são originárias de produtoras cariocas ou paulistas. Cidade Baixa (2005), dirigido pelo baiano Sérgio Machado, utilizou a cenografia do Recôncavo Baiano e atores locais como Lázaro Ramos e Wagner Moura, mas a produtora Videofilmes responsável pela captação estava localizada no Rio de Janeiro. O mesmo aconteceu com Baixio das Bestas (2007), dirigido pelo pernambucano Claudio Assis, e filmado na Zona da Mata do seu estado. A produtora era a, também carioca, Reserva Cultural. 
No caso baiano, os tempos de protagonismo no cinema nacional presentes nas décadas de 1950 e 1960 ficaram no passado, e este não se reergueu, mesmo com digitalização e as primeiras ações estaduais na década de $1990 \mathrm{em}$ termos de incentivos fiscais. É o que levanta Daniela Pfeiffer Fernandes (2010), ao situar o amadurecimento dos movimentos dos independentes no estado e suas relações com as políticas estatais nacionais e locais para reerguer o cenário nos anos 2000. Isso acaba por repercutir no avanço nas ações do governo do estado com as mudanças no gerenciamento a partir de 2007. Todavia, o gargalo na distribuição e os limites nos avanços regulatórios, em nível federal, dificultavam uma organização produtiva mais sólida.

Nesse sentido, a dedicação do mandato de Jandira Feghali em torno da regulamentação do Art. 222 ia além dos anseios do seu estado, o Rio de Janeiro. A possibilidade de normatizar a associação entre a produção independente e regional à TV aberta era um objetivo traçado há décadas pelos independentes. Entre 2007 e 2010, durante a tramitação da Lei 12.485, Feghali estava fora do parlamento, e foi nesse período que a valorização da produção independente e regional avançou no Congresso. Entretanto, não foi a regulamentação do Capítulo V da Constituição, nem a televisão aberta a plataforma responsável por abrir a discussão. Também não foi o grupo do audiovisual nacional e independente. $\mathrm{O}$ debate em torno da Lei 12.485 começou a partir de demandas das empresas de telefonia, conforme veremos no próximo capítulo. 


\section{CAPÍTULO IV}

\section{A REDE SE CONSTITUI E TRANSBORDA}

Neste capítulo final, vamos demonstrar que, a partir do contexto traçado, foram constituídas as condições para debater e, posteriormente, aprovar a Lei da TV Paga. Veremos como foi o seu processo de elaboração no Congresso Nacional e os vínculos com os movimentos dos demais mediadores que reforçaram sua ratificação entre 2007 e 2012; esse último, ano de regulamentação da Lei por meio da Instrução Normativa 100. Ao final, vamos levantar um curto panorama da Rede nos três primeiros anos de vigência da Lei, e apontar alguns transbordamentos, ou seja, elementos não considerados na Lei 12.485 com vínculos estreitos com o audiovisual em circulação na "Lei da TV Paga".

\subsection{OS TRÊS PROJETOS BASE}

"Guerra anunciada", esse foi o título de uma reportagem em setembro de 2006 (POSSEBON, 2006) da revista Tela Viva. Na ocasião, a ABTA e as empresas de telefonia disputavam a exploração do mercado de TV por assinatura. Liderada por representantes da Sky e Net, a ABTA solicitou à Anatel o veto às operadoras de telefonia fixa no DTH, bem como a compra da operadora a cabo, Way TV, em Minas Gerais, pela Telemar. O argumento utilizado era de que as teles tendiam a concentrar o mercado e cometer infrações à Lei do Cabo. No mês de Abril de 2007, a mesma revista retornava ao tema, desta vez, com as decisões da Anatel de permitir a entrada da Telefônica no DTH, e de vetar a operação da Telemar no cabo (POSSEBON, 2007). A discussão em torno da tecnologia estava vinculada ao movimento dos grupos empresariais: 
"a tecnologia sempre foi menos determinante para o negócio do que para a regulamentação. $\mathrm{O}$ serviço era a mesma coisa. As pessoas não tinham muita clareza. Tinham vantagens competitivas. mas do ponto de vista do mercado, é irrelevante. (POSSEBON, 2014, informação oral) ${ }^{73}$

No meio da disputa, o deputado federal Paulo Bornhausen (DEM-SC) ${ }^{74}$ atendeu demandas da Associação Brasileira de Concessionários de Serviço Telefônico Comutado (Abrafix) e apresentou o Projeto de Lei 29/2007, conhecido como PL 29, na Comissão de Ciência e Tecnologia, Comunicação e Informática (CCTCI), no dia 5 de fevereiro de 2007. A proposta era revisar regras no conteúdo a ser distribuído por meio dos serviços de telecomunicações, e, dessa forma, ampliar as licenças para prestação do serviço de televisão a cabo para as operadoras de telefonia fixa, e flexibilizar a exploração da distribuição por empresas estrangeiras. ${ }^{75}$ Por fim, o projeto regulamentava a entrada das teles na radiodifusão e internet.

O PL 29 respondia atuação da Globo expressa desde seminário na PUC-SP em 2004 de impedir a entrada das distribuidoras e empresas internacionais no conteúdo. No Congresso Nacional, tais objetivos da Globo foram capitaneados por Nelson Marquezelli (PTB-SP) no extinto PL 4.209/2004. No dia 5 de fevereiro, o mesmo Marquezelli retomou os anseios no PL 70/2007, prontamente apensado ao PL 29 pelo relator Jorge Bittar (PT-RJ). Nas justificativas, o parlamentar paulista apresentou os seguintes argumentos:

Na realidade, a produção e a transmissão de bens culturais assumiu o papel
de instrumento hegemônico de economias centrais, ocupando o quinto lugar
em termos de importância econômica no mundo. Além de seu valor econô-
mico direto, essa indústria é parte de uma estratégia de dominação cultural
dos mercados emergentes, em apoio à dominação econômica e política, dis-
seminando valores, criando demanda e abrindo mercados desvinculados da
realidade e dos interesses nacionais. (PL 70/2007)

Durante um mês Jorge Bittar se articulou com os companheiros de partido Walter Pinheiro (PT-BA) e Paulo Teixeira (PT-SP) para apensar um terceiro projeto para entrar no debate, o PL 332/2007, apresentado no dia 7 de março do mesmo ano. O ponto de partida da proposta era dispor sobre uma sistematização da cadeia produtiva em: produção, programa-

73 POSSEBON, Samuel. Entrevista I. [jul.2014]. Entrevistador: Pedro Andrade Caribé. Brasília, 2014. 2 arquivos .mp4 (65 $\mathrm{min})$

74 Paulo Bornhausen é filho de um homem conhecido há décadas na política brasileira, o ex-senador e concessionário de uma rádio FM em Criciúma, Jorge Bornhausen (DEM-SC). Foi um dos relatores da LGT, e, no ano de 2007, foi apontado pelo Departamento Intersindical de Assessoria Parlamentar (DIAP) como um dos cem deputados mais influentes na Câmara.

75 A primeira proposta de Paulo Bornhausen também visava regulamentar o provimento do serviço de internet no país. A proposta foi endossada por outros parlamentares, mas não avançou. Ainda assim, o objetivo de Bornhausen e dos demais interessados não era regulamentar a programação do conteúdo na internet, Consequentemente, o resultado final da Lei 12.485/2011 deixa um vácuo no acompanhamento dos serviços over-the-top (OTT), ou mesmo, o apoio à produção nacional e independente que circula em plataformas gratuitas como Youtube e Vimeo. 
ção, provimento, empacotamento e distribuição. Conforme relata Dantas (2014, informação $\mathrm{oral}^{76}$ ), esse modelo surgiu nas reuniões realizadas no Rio de Janeiro articuladas pelo mandato de Bittar:

\begin{abstract}
Bittar recebeu a relatoria, e o assessor do mandato, Marcelo Miranda, montou um grupo para subsidiar. O grupo começou a discutir o projeto semanalmente e entrevistar executivos e consultores do mercado. No espaço nasceu um conjunto de ideias que se tornariam eixo da lei. Quanto à cadeia, utilizei referências da Televisão Sem Fronteiras, e Alex Patêz apresentou uma noção sobre a cadeia produtiva do setor a partir de sua dissertação sobre a economia da TV por assinatura. E começamos a elaborar as primeiras versões de projeto maior.
\end{abstract}

\title{
4.1.1 "O Tratado de Tordesilhas"
}

Estruturada a cadeia, o segundo passo chave na formulação apresentada por Teixeira e Pinheiro foi diferenciar conteúdos transmitidos por radiodifusão, e o conceito regulatório introduzido foi o da comunicação social eletrônica de acesso condicionado: "a transmissão de conteúdo eletrônico, o qual admite interação, cuja recepção é condicionada à contratação prévia" (PL 332/2007). Impedia-se, dessa forma, nova interdição do processo, com o argumento de ferir a Constituição na proposição, pois há uma distinção explícita entre as regras para o novo conceito e as regras da radiodifusão, que, por sua vez, deveriam ser submetidas estritamente ao Capitulo V da Constituição.

No acesso condicionado e quaisquer outras atividades relacionadas a conteúdo oriundo de serviços de telecomunicações (inicialmente, até mesmo aquelas distribuídas por protocolos IP eram consideradas), os parlamentares petistas defenderam a entrada irrestrita das teles, e, assim, coadunavam com os anseios externados no PL 29 de Paulo Bornhausen.

No começo, a Globo estava teoricamente isolada, pois parlamentares do partido da Presidência da República e um parlamentar do partido mais inciso na oposição se juntaram no caminho, a priori, insatisfatório para a família Marinho. Mas, o resultado final da primeira rodada de negociação para o andamento do projeto teve como contrapartida exatamente o que a Globo queria: retirar as operadoras de telecomunicações de qualquer atividade direta no conteúdo:

Fiz muitas audiências públicas e diálogos. Tinha uma resistência grande da Globo. Ela utilizava o argumento que a concorrência com as teles era desi-

76 DANTAS, Marcos. Entrevista II. [ago.2014]. Entrevistador: Pedro Andrade Caribé. Videoconferência. 2 arquivos .mp4 (53 min). 
gual. Houve uma situação favorável à entrada das teles no mercado [de tv por assinatura]. Até a Globo entrar para conversar. Ela já tinha inserção nos canais Globosat, e começou com a ideia que as teles não poderiam controlar grandes eventos como campeonato brasileiro e grandes talentos. Aí começou a se desenhar um acordo dessa natureza. As teles alegavam que era bobagem da Globo porque não queriam entrar no conteúdo. Eles [Globo] já vinham num processo de saída na distribuição. Queriam vender as ações da Net à Telmex. Enquanto as teles eram mais representadas pela Telefônica e Oi, e a GVT menos. (BITTAR, 2014, informação oral) 77

Dessa forma, foi firmado acordo base para o desenvolvimento do projeto entre Globo e teles, denominado "Tratado de Tordesilhas". Nota-se, no depoimento de Bittar, a não prioridade das teles em entrar no mercado do conteúdo, o que incluía as outorgas de radiodifusão. E isso se confirmou ao longo dos materiais coletados nesta dissertação, representados na crescente distinção entre a atuação executiva dos programadores e distribuidores. A meta chave defendida entre as teles era aproveitar o aumento da capacidade de consumo da população com o fortalecimento do conteúdo na TV por assinatura para angariar mais assinantes.

Ainda assim, restava um ator para concluir o "Tratado": o grupo Bandeirantes. Desde o começo da tramitação, o executivo Johnny Saad atuou para impedir as restrições da radiodifusão na distribuição, porque detinha o controle da operadora de TV por assinatura a cabo, a Sim TV, originária da TV Cidade. A tentativa de impedir o "Tratado" ao longo da aprovação da Lei, e até a posteriori, foi em vão. Além de perder nesse ponto, ele tinha que disputar espaço nos segmentos da cadeia mais discutidos na Lei: a programação e o empacotamento.

\subsubsection{A reserva na programação}

Ao acertar que as teles ficariam restritas à distribuição e que as regra da TV por assinatura seriam unificadas no serviço de acesso condicionado, mais um ator se insurgiu: a Sky/DirecTV, responsável por 90\% das operações em DTH no país em 2007. O DTH era regido apenas por uma portaria da LGT, estava livre para atuação das empresas estrangeiras e telefônicas, e não seguia as obrigações concessionárias do cabo. Na época, a entrada das telefônicas no DTH fora confirmada pela Anatel, e o objetivo do executivo da Sky, Luiz Fernando Baptista, o "Bap", era impedir as tentativas de acoplar medidas obrigatórias ao conteúdo brasileiro na operação. Conforme Bittar relatou em entrevista a esta dissertação:

A Sky começou a ficar contra, porque saía de portaria frouxa para uma lei cheia de restrições. E, aí, foi um adversário desleal. Ele foi para dentro da

77 BITTAR, Jorge. Entrevista VII . [nov. 2014]. Entrevistador: Pedro Andrade Caribé. Brasília, 2014.1 arquivo .mp4 (60 $\mathrm{min})$. 
ABTA e convenceu os caras a fazer a campanha com esportistas contra a lei. (BITTAR, 2014, informação oral $^{78}$

A atuação da Sky encontrou, inicialmente, mais dois aliados contrários às medidas de apoio ao conteúdo brasileiro: a Globo e as programadoras estrangeiras. Isso, porque o PL dos petistas buscava implementar uma novidade na TV por assinatura: reservar percentual para veiculação de conteúdo produzido por empresas brasileiras, com o dever de adquirir conteúdos de terceiros, preferencialmente de produtores de diferentes regiões do País.

Até então, a Globo buscava, na tramitação, afastar as empresas estrangeiras nos contratos de exploração da distribuição dos serviços, sem interesse de incluir qualquer medida de reserva ao conteúdo brasileiro diretamente na grade de programação dos canais:

A Globo vinha do discurso que não tinha de ter regulamentação no serviço, o mercado é que deveria moldar. Ela fazia o discurso que só propriedade deveria ser regulada. A discussão nacional da Globo vai até determinado ponto. Quando entram os pequenos, vira problema do 'mercado'. (NAZARENO, 2014, informação oral) ${ }^{79}$

“Os pequenos" mencionados por Claudio Nazareno, Consultor Legislativo da Câmara dos Deputados, são os membros do audiovisual nacional e independente. Durante o processo, o acompanhamento majoritário das demandas do grupo ficou a cargo da ABPI-TV. Seja no grupo de trabalho montado por Bittar ou nas audiências públicas, a Associação estruturou um modelo de atuação considerado mais profissional, estruturado em parâmetros de legislações internacionais e informações do mercado. Conforme Alex Patêz relatou: "Cheguei a comentar com o Manoel Rangel: mesmo que nada aconteça, o pessoal do audiovisual foi para dentro do Congresso. Isso muda para sempre o panorama" (PATÊZ, 2014, informação oral). ${ }^{80}$

Nesse momento, a participação do conteúdo produzido por esse grupo ainda é reduzida na maioria das programadoras nacionais e estrangeiras da TV por assinatura. Porém, as leis de incentivo, em especial, a junção entre o Art. $3^{\circ}$ da Lei do Audiovisual e Condecine-Remessas, normatizado na Medida Provisória que criou a Ancine, desenvolveram uma expertise na coprodução entre os independentes e os programadores internacionais. E, dessa vez, o aprofundamento dessa expertise com regras mais sólidas correspondia ao principio da "Exceção Cultural":

78 BITTAR, Jorge. Entrevista VII . [nov. 2014]. Entrevistador: Pedro Andrade Caribé. Brasília, 2014. 1 arquivo .mp4 (60 min).

79 NAZARENO, Claudio. Entrevista VI. [set. 2014]. Entrevistador: Pedro Andrade Caribé. Brasília, 1 arquivo .mp4 (49 $\mathrm{min})$.

80 PATÊZ, Alexander. Entrevista IX. [dezembro.2014] Entrevistador: Pedro Andrade Caribé. Rio de Janeiro, 2014. 1 arquivo .mp4 (72 $\mathrm{min})$. 
Os estrangeiros não vão trazer a produção deles para fazer conteúdo brasileiro. Também não é mais o modelo brasileiro de tv que a casa faz tudo. A Globo começou a abrir. Ela não pode com tanto canal de tv por assinatura se dedicar a produzir todas essas coisas. Foi então que Ancine, via governo brasileiro, colocou na parede: "Vocês vão conseguir fazer tudo isso?. Foi a partir da EBC que desenhamos isso. Foi aí que colocamos que metade tem que ser feito fora, e metade regional. É outra visão. (SENNA, 2014, informação oral) ${ }^{81}$

\subsection{O RELATÓRIO FINAL DE BITTAR}

Durante um ano e dois meses, Jorge Bittar foi o relator do PL 29. Ele apresentou seu parecer final no dia 4 de julho 2008. Durante esse período, o projeto recebeu dezenas de emendas, foi a três audiências públicas, passou na Comissão de Desenvolvimento Econômico, Indústria e Comércio (CDEIC $)^{82}$ e no Plenário da Câmara. Até chegar à proposta final mais cinco proposições circularam, e o ponto chave das divergências foi a reserva aos canais brasileiros disponibilizados nos pacotes ofertados aos consumidores.

Os entrevistados para esta dissertação não desmereceram as emendas e projetos de Lei apresentados nesse período. Por exemplo, o mandato de João Maria (PR/RN) teve seu pedido deferido, e, assim, foi apensado o Projeto de Lei 1.908/2007 apresentado na CDEIC. João Maria seguiu a linha de regulamentar os segmentos da cadeia produtiva, e também de prever maior participação da produção nacional com a reserva de $50 \%$ na programação, sendo que deste percentual $10 \%$ deveria ser produzido por produtores independentes brasileiros. $\mathrm{O}$ parlamentar também defendeu disponibilizar gratuitamente os canais em VHF e UHF na TV por assinatura. Já o deputado Moreira Mendes (PPS-RO) teve 21 emendas acatadas, mesmo que parcialmente.

Entretanto, o diálogo direto com os grupos sociais predominantes continuou tendo como eixo os três projetos apensados na CCTCI e a condução do deputado Bittar; enquanto a Ancine, por meio de grupo de trabalho coordenado por Alex Patêz, continuou o trabalho do mandato e fez a função de articular a formulação dos conceitos com dados de mercado e auxílio da Anatel, acadêmicos, produtores independentes e representantes empresariais.

O projeto retornou à responsabilidade formal de Jorge Bittar no final de novembro de 2007. Nesse momento, a importância da matéria pode ser mensurada na quantidade de novas

81 SENNA, Orlando. Entrevista VIII. [nov.2014]. Entrevistador: Pedro Andrade Caribé. Rio de Janeiro, 2 arquivos .mp4 (132 $\mathrm{min})$.

$82 \mathrm{Na}$ CDEIC a relatoria ficou sob responsabilidade do "coronel midiático" Wellington Fagundes (PR-MT), concessionário de três retransmissoras (afiliadas do SBT e Record) registradas em nomes de parentes em Rondonópolis, Jaciara e Barra do Garças. 
emendas enviadas na CCTCI: ao total 145. Quanto ao Poder Executivo, alguns espaços também estavam contribuindo com o desenrolar do PL 29:

Não tive nenhum apoio do Ministério das Comunicações. Era o Hélio Costa. Ele era próximo ao Evandro Guimarães [executivo da Globo]. Já o então ministro da cultura, Gilberto Gil, e Juca Ferreira foram aliados próximos. Militaram ostensivamente. Na Casa Civil, estava Dilma, ela apoiou e queria até aumentar as cotas. (Bittar, 2014, informação oral, acréscimos nossos) ${ }^{83}$

\subsubsection{A radiodifusão}

O relatório final de Bittar apresentou uma elaboração definitiva do "Tratado de Tordesilhas", traduzido nos Art. $5^{\circ}$ e $6^{\circ}$ da Lei 12.485/2011. As operadoras de telecomunicações não podem ultrapassar em $30 \%$ a participação nos capitais totais das concessionárias de televisão, produtoras e programadoras. Também ficariam proibidas de adquirir direitos de exploração de imagens de eventos de interesse nacional, assim como de contratar talentos artísticos nacionais, exceto na produção de peças publicitárias.

Segundo o Diretor Geral da Abert, Luis Roberto Antonik (2014, informação oral ${ }^{84}$ ): "as emissoras atuaram isoladamente para os artigos quinto e sexto. $\mathrm{O}$ consenso entre as associadas foi no artigo 32. Nesse trabalhamos passo a passo". Conhecido como must-carry, o artigo 32 trata do empacotamento da radiodifusão e dos canais públicos na TV por assinatura. $\mathrm{Na}$ ocasião, o documento apresentado na CCTCI definia como obrigatório o carregamento dos canais abertos presentes no município de atuação da operadora, e isso incluía reserva para os canais públicos previstos no SBTVD, bem como aqueles originários da Lei do Cabo; além de uma novidade: retransmitir uma emissora oficial do Poder Executivo.

O único impeditivo antecipado no relatório de Bittar, para não carregar esses canais, era de fator técnico, pois, nessa situação, as distribuidoras por satélite têm maiores dificuldades de segmentar, em cada praça, todos os canais abertos, e cabe à Anatel avaliar se as justificativas são plausíveis, ou se se trata apenas de indiferença política ou econômica. Entretanto, veremos que até a Lei ser finalizada mais um entrave se apresentou para o must-carry.

83 BITTAR, Jorge. Entrevista VII . [nov. 2014]. Entrevistador: Pedro Andrade Caribé. Brasília, 2014. 1 arquivo .mp4 (60 min).

84 ANTONIK, Luis Roberto. Entrevista IV [ago. 2014]. Entrevistador: Pedro Andrade Caribé. Brasília, 2014. 1 arquivo .mp4 (58 min). 


\subsubsection{Valorização do conteúdo brasileiro e independente}

A fim de atender os independentes, o relatório de Bittar apresentou um arranjo no qual o fomento por meio do FSA aumentaria consideravelmente. Não criou novo imposto, nem reverteu os recursos oriundos da renúncia fiscal. Diminuiu a arrecadação do Fundo de Fiscalização das Telecomunicações (Fistel) e passou a reverter parte do débito, costumeiramente, parado no Tesouro da União, ${ }^{85}$ para investimentos no audiovisual. Dessa forma, a Taxa de Fiscalização de Funcionamento (TFF) do Fistel foi reduzida em 11\%, e repassada para o Condecine, utilizando como referência a recente Lei 11.552 (BRASIL, 2007) de criação da TV Pública. ${ }^{86} \mathrm{O}$ montante desses recursos destinado às regiões Norte, Nordeste e Centro-Oeste $(30 \%)$ também foi estabelecido nesse momento, bem como a destinação de $10 \%$ para emissoras universitárias e comunitárias, só acrescentando as programadoras independentes, essa última fatia no decorrer do processo. O recurso, antes administrado pela Anatel, passaria ao poderes da Ancine.

Desde a Embrafilme, o fomento ao audiovisual independente no Brasil é prática recorrente das políticas estatais. O gargalo sempre foi na distribuição e exibição, e isso se complexificou com a entrada da TV por assinatura na década de 1990. O número baixo de longasmetragens exibidos nessa plataforma pode ser ilustrado na Figura 2. No ano de 2008, em que transcorria o relatório final de Bittar, treze canais foram destacados para a Ancine. O TNT e o Telecine Cult só exibiram uma obra nacional, e o HBO, Telecine Action e Telecine Ligh nenhuma.

Sem avanços na regulamentação da TV aberta, mais uma vez, assim como ocorreu na "Lei do Cabo", a TV paga seria o espaço para discutir alguma forma de participação do conteúdo nacional independente:

Tivemos vários momentos do cinema brasileiro com filmes inéditos por anos por não ter onde passar, nem na tv, nem nas salas de cinema. Só passava em festivais. O que o SeAC faz? Toca num ponto fundamental da distribuição. E o FSA tem como condição básica ter a exibição garantida. Tem que ter contrato de licenciamento de canal, não adianta produzir, tem que garantir a distribuição. (GARCIA, 2014, informação oral) ${ }^{87}$

85 No relatório final da CCTCI, a arrecadação anual do Fistel foi calculada em R\$ 3 bilhões, todavia, apenas cerca de $\mathrm{R} \$ 300$ milhões eram utilizados pela Anatel por ano.

86 A TFF era fixada em 50\% da Taxa de Fiscalização de Instalação (TFI) do Fistel. Desde Medida Provisória que criou a TV Pública, esse percentual foi alterado para 45\%. Na "Lei da TV Paga", o percentual caía ainda mais: $33 \%$.

87 GARCIA, Mauro. Entrevista III. [ago.2014]. Entrevistador: Pedro Andrade Caribé. Videoconferência, 2014. 1 arquivo .mp4 (70 min). 
Figura 2 - Longas-metragens brasileiros na TV por assinatura em 2008

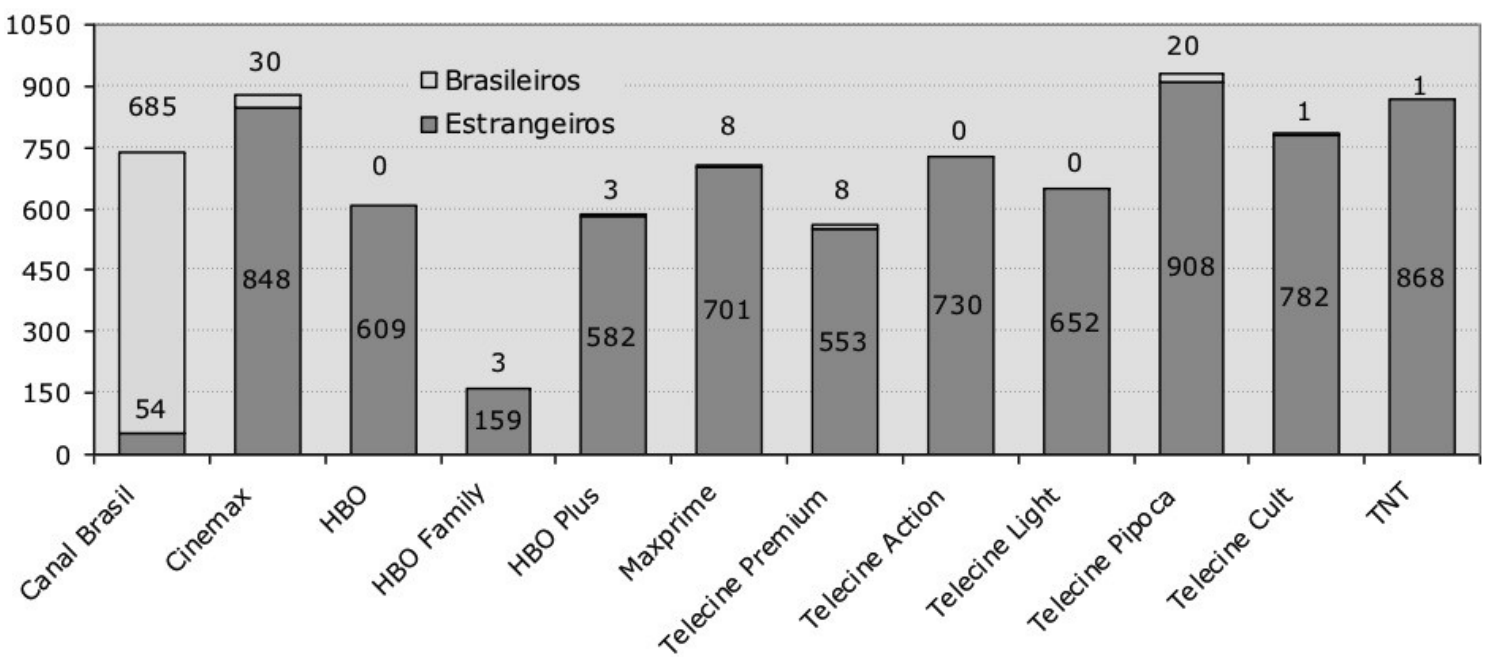

Fonte: ANCINE, 2008, com adaptações.

A garantia da distribuição para o conteúdo brasileiro e independente passou primeiro por aperfeiçoamento na formulação frente à maior complexidade de gêneros e formatos no audiovisual. Por isso, foi introduzido no relatório final de Bittar o conceito de espaço qualificado. Influenciado no modelo de canais relevantes da União Europeia e também formulado com ajuda da Ancine, o conceito caminhou na negativa, ao excluir o que não pode se enquadrar nesse perfil. A gênese está em buscar conteúdos valorizados na transação dos direitos autorais e, consequentemente, maior potencial econômico devido à capacidade de negociação internacional e adaptação de formatos. Integram a base dos formatos almejados: séries, minisséries, longas-metragens, documentários, animações e reality-shows.

Quanto mais os canais veiculam esses formatos, mais as possibilidades de tornaremse canais de espaço qualificado. Para se tornar um canal brasileiro de espaço qualificado é necessário ser originário de programadora brasileira, veicular majoritariamente conteúdo qualificado brasileiro no horário nobre, metade do qual produzido por produtora independente, e estar disponível para livre comercialização para qualquer empacotadora.

Nesse estágio, chegou-se à conclusão de que os canais com conteúdo majoritariamente qualificado seriam obrigados a veicular $3 \mathrm{~h} 30 \mathrm{~min}$ de conteúdo brasileiro, metade produzido por produtora brasileira independente. A Globo não era mais um adversário nesse ponto, enquanto os programadores estrangeiros continuavam a divergir:

A Globo era receosa sobre esse debate. As cotas eram desconfortáveis para a Globo porque poderia criar precedente para a tv aberta. Mas tinha as demandas da Ancine, e a Globo acabou cedendo os pontos da Ancine porque viu 
que não era prejudicial aos negócios dela. A reticência das programadoras internacionais se deu por dois motivos: primeiro, passa a ter que negociar com conteúdo nacional, e até descaracterizar a parte artística de alguns canais; segundo, se faz isso no Brasil, pode repercutir no resto do continente. (POSSEBON, 2014, informação oral $)^{88}$

O segundo ponto destacado acima por Possebon foi recorrente nas demais entrevistas. Tecnicamente, o discurso era que o sistema de satélite repassava para a América Latina de forma homogênea os canais e qualquer modificação iria encarecer a atividade. Politicamente, o problema era outro. Bittar alega ter recebido um representante direto dos EUA em nome dos canais: "Ele me disse: 'Vou ser sincero, nosso problema é que isso se propague por outros países"”. A preocupação não era à-toa, o modelo brasileiro de TV digital, paulatinamente, foi incorporado por países na América do Sul, e o parlamentar petista foi convidado para auxiliar um país vizinho a elaborar uma Lei de Meios, a partir dos conhecimentos acumulados na matéria em questão: “Quando o [Néstor] Kirchner queria fazer a Lei de Medios, o Lula nos indicou. E o Ministério das Comunicações da Argentina me recebeu junto com Nazareno. De alguma maneira subsidiamos a Lei deles" (BITTAR, 2014, informação oral, acréscimo nosso). ${ }^{89}$

\subsubsection{A disputa em torno das cotas no empacotamento}

O apoio da Globo pavimentou o caminho para definir as cotas na programação. O maior entrave no desenvolvimento passou a ser as cotas no empacotamento, ou seja, definir quantos canais no catálogo ofertado pelos distribuidores deveriam ser brasileiros e independentes. Vale ressaltar que, no relatório apresentado por Bittar, a sistematização da cadeia ganhou o desenho final: distribuição, empacotamento, programação e produção.

Entre os quatro, o empacotamento é uma novidade em parâmetros internacionais. Sua função é entregar as possibilidades de canais aos assinantes, inclusive os avulsos ou sob demanda. A proposta foi defendida pela Ancine e permite uma interligação com a ação regulatória da Anatel, pois as empresas de distribuição/empacotamento passaram a ter os dados das suas movimentações acompanhados nas duas agências. A justificativa apresentada pela Ancine para inovar com o empacotamento foi apreendida no histórico de concentração da televisão aberta nas diversas camadas da cadeia:

88 POSSEBON, Samuel. Entrevista I. [jul. 2014]. Entrevistador: Pedro Andrade Caribé. Brasília, 2014. 2 arquivos .mp4 (65 min).

89 BITTAR, Jorge. Entrevista VII . [nov. 2014]. Entrevistador: Pedro Andrade Caribé. Brasília, 2014. 1 arquivo .mp4 (60 min.). 
O mercado brasileiro de TV por assinatura se consolidou de forma parecida à radiodifusão aberta. E o conceito tem a ver com isso. Quando você estabelece a regulação por camada, se ficar só programação e distribuição, corria 0 risco de não pegar tudo. A Globo em determinado momento começou a fazer algo parecido à tv aberta, ao filiar operadoras do cabo, via Net Brasil. Era empacotamento. Inclusive a TV Cidade que é do SBT foi incluída. Estava faltando esse ente. Hoje tem poucos exemplos, duas ou três empresas que montam os canais e oferecem às que tem rede. Geralmente a operadora atua nas duas atividades. (PATEZ, 2014, informação oral)

A Sky também não se interessava por fixar cotas entre os canais e buscava evitar que isso se alastrasse na América Latina. Todavia, os mais interessados em impedir esse processo eram as programadoras estrangeiras e também as Organizações Globo. Essa última tinha poder de veto ao conteúdo nacional nas duas maiores operadoras do país, mesmo em canais estrangeiros, devido aos acordos de exclusividade firmados com a Sky e a participação na Net.

No relatório da Ancine de 2010, é possível perceber a imbricação entre o grupo nacional e os estrangeiros. Os dois formam dois troncos básicos nos pacotes, sintetizados como Telecine (Figura 4) e HBO (Figura 5). A origem dessa divisão é histórica na TV por assinatura brasileira, a partir das disputas por exclusividade entre a TVA(Abril) e Net/Sky (Globo).

Nessa arquitetura, a Globo até permitia a reserva de canais brasileiros qualificados, desde que não se facilitasse para demais grupos nacionais como Band e Record entrarem no bojo da reserva. Ou seja, tinha que ser uma quantidade suficiente para continuar a predominarem os canais Globosat. O segundo interesse da Globo era impedir reserva para canais jornalísticos ao ponto de a BandNews e de a RecordNews também terem participação garantida nos pacotes (POSSEBON, 2014, informação oral). ${ }^{90}$

No impasse, o relatório apresentado por Bittar no dia 4 de julho de 2008 tentou reservar $25 \%$ dos canais como brasileiros e desses $1 / 3$ deveria ser independente. ${ }^{91}$ Não adiantou, porque o projeto seria travado na Câmara: "Isso foi o maior problema. Empacou o andamento por um ano e meio" (PATÊZ, 2014, informação oral).

90 POSSEBON, Samuel. Entrevista I. [jul. 2014]. Entrevistador: Pedro Andrade Caribé. Brasília, 2014. 2 arquivos .mp4 (65 min).

91 No relatório de Bittar, canal independente era tratado como canal incentivado. 
Figura 4 - Tronco básico no pacote Telecine

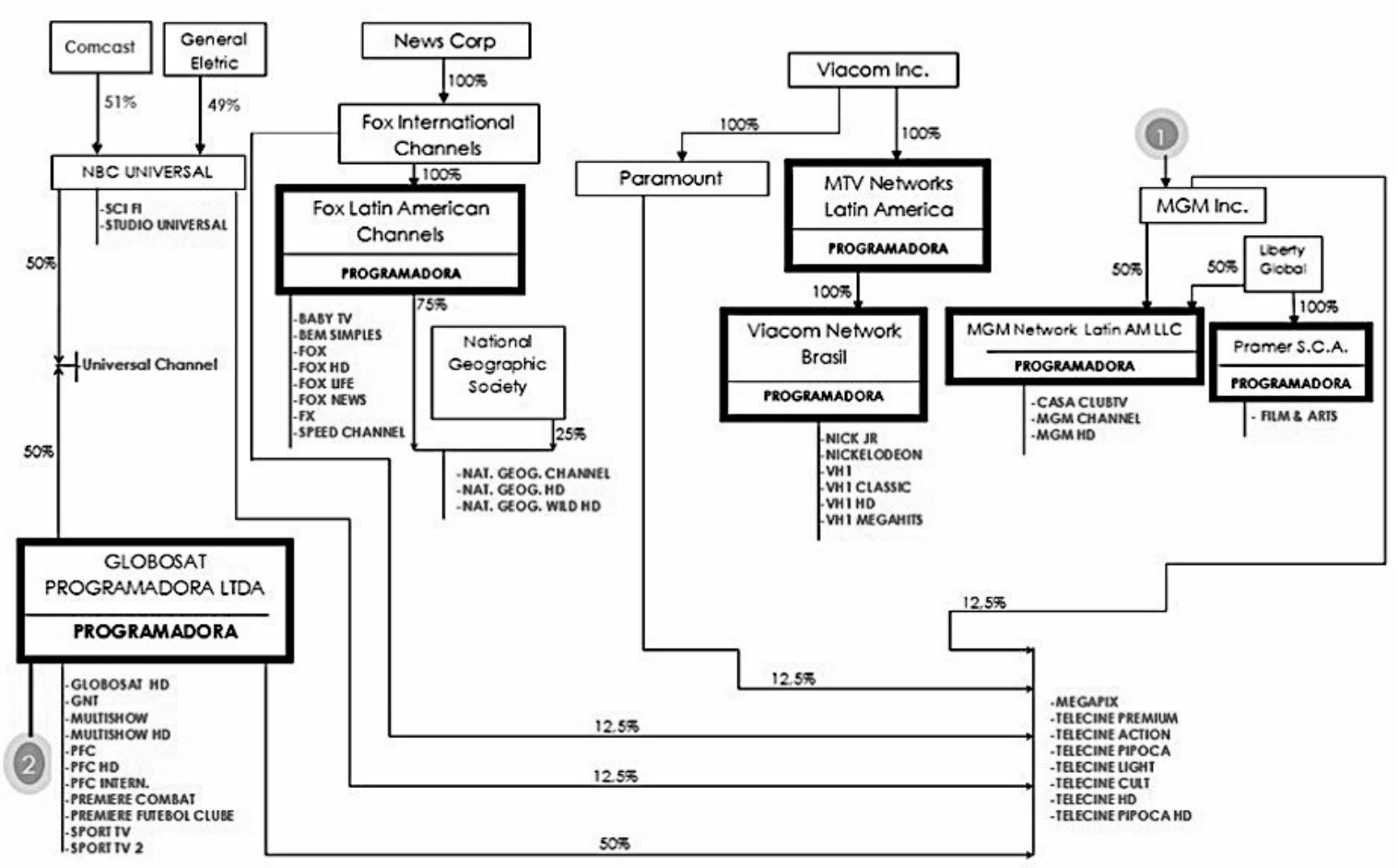

Fonte: Ancine, 2010, p. 34-35, com adaptações.

Figura 5 - Tronco básico no pacote HBO

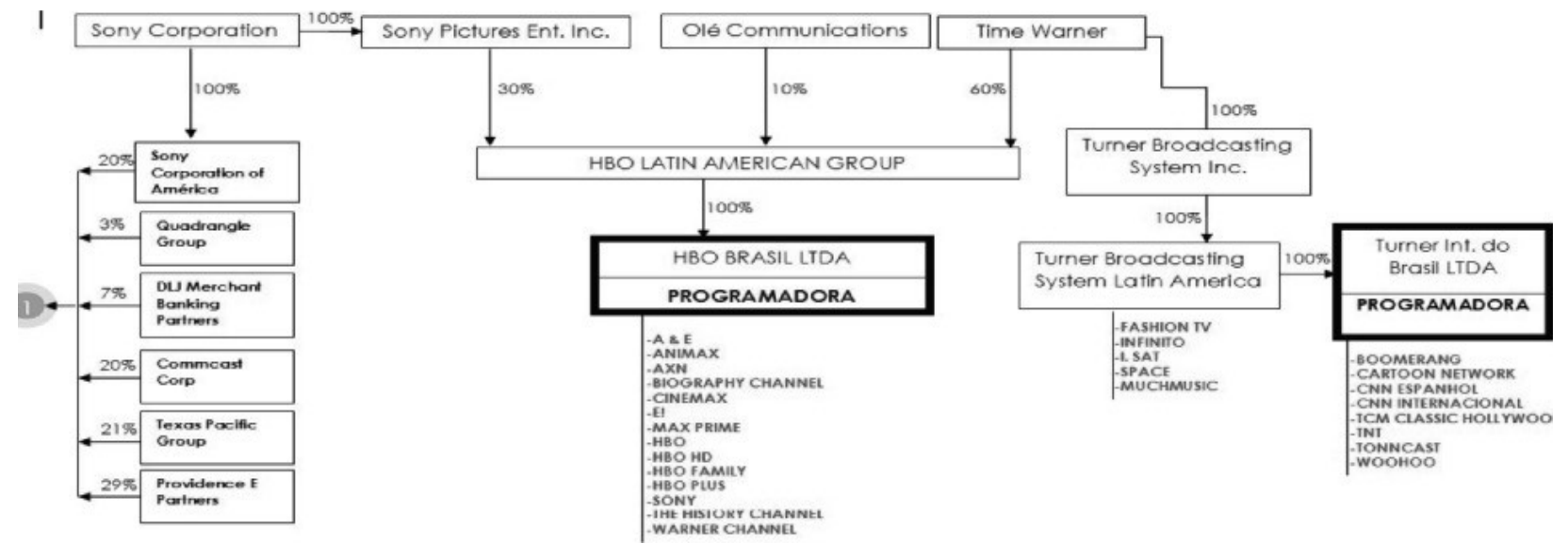

Fonte: Ancine, 2010, p. 34-35, com adaptações. 


\subsection{COMISSÃO DE DEFESA DO CONSUMIDOR}

No dia 8 de julho de 2008, quatro dias após o parlamentar petista apresentar a conclusão dos trabalhos, o deputado Paulo Renato Sousa (PSDB-SP) solicitou participação da Comissão de Finanças e Tributação, com a justificativa de que o projeto de lei envolvia questões estratégicas como a participação do capital estrangeiro na exploração da TV por assinatura. ${ }^{92}$. Um dia depois (em 9 de julho de 2008), foi a vez de Cezar Silvestri (PPS-PR) fazer o mesmo pedido, porém para a Comissão de Defesa do Consumidor (CDC), sob o argumento de que a TV paga tem altos índices de reclamação dos usuários, e tal situação poderia se intensificar com a possibilidade de ampliar a venda do serviço em conjunto às mudanças propostas no relatório. ${ }^{93}$

$\mathrm{Na}$ avaliação dos consultores legislativos entrevistados, ocorrem duas percepções sobre os pedidos: a primeira de que as manobras visavam apenas atrasar o andamento do projeto; e, na segunda hipótese, as manobras visavam atrasar o projeto, porque mais parlamentares gostariam de participar do processo. A decisão da Mesa Diretora da Câmera, no dia 26 de agosto, foi remeter apenas para a CDC, e, no dia $1^{\circ}$ de setembro, Vital do Rêgo (PMDB-PB) assumiu a respectiva relatoria. Foram realizadas mais quatro audiências públicas com a presença dos atores mais envolvidos no PL 29 e novas emendas em substitutivo. Até que, um ano depois, no dia 2 de setembro de 2009, Vital do Rêgo apresentou o relatório final.

No documento, foram reafirmados os princípios fundamentais, inclusive os presentes na Convenção sobre a Proteção e Promoção da Diversidade das Expressões Culturais. Porém, dessa vez, foi introduzida, nos deveres da programação, a adoção de um sistema de Classificação Indicativa, posteriormente aperfeiçoado para o resultado conclusivo na Lei 12.485 no Art. 7, sob responsabilidade de fiscalização do Ministério da Justiça, a partir das informações repassadas das agências regulatórias envolvidas.

O CDC também substituiu a expressão "evento nacional" por "evento de interesse nacional" e, assim, incorporou eventos ocorridos fora do território brasileiro, como Olimpíadas Esportivas e Copa do Mundo de Futebol, ambas, alvo de disputas entre empresas de pro-

92 Disponível em:

<http://www.camara.gov.br/proposicoesWeb/prop mostrarintegra;jsessionid=0646C2887038425528B79FF0 45DF4956.proposicoesWeb1?codteor $=584402 \&$ filename $=$ Tramitacao-PL+29/2007>. Acesso em: 25 jan. 2015.

93 Disponível em:

$<\underline{\text { http://www.camara.gov.br/proposicoesWeb/prop mostrarintegra;jsessionid=0646C2887038425528B79FF0 }}$ 45DF4956.proposicoesWeb1 ? codteor $=584804 \&$ filename $=$ Tramitacao-PL+29/2007> . Acesso em: 25 jan. 2015. 
gramação em atuação no Brasil. Nesses eventos, as operadoras não poderiam mais aventar disputar direitos de transmissão.

Quanto ao modelo de produtora independente, também foi durante a tramitação na CDC que a Lei 12.485 chegou a uma noção singular no país e passou a ser qualquer um sem controle ou coligação com canais de programação, ${ }^{94}$ estejam eles na TV aberta ou na TV por assinatura. Dessa forma, a GloboFilmes perdeu qualquer possibilidade de voltar a captar recursos por meio do Fundo Setorial do Audiovisual. E, caso voltasse a utilizar os mecanismos de renúncia fiscal, ${ }^{95}$ o conteúdo não poderia ser enquadrado como independente.

Durante um ano, na CDC, também se iniciou debate sobre diferenças de tratamento no must-carry entre os canais abertos digitais e analógicos. No empacotamento, a única decisão que seguiu adiante foi retirar a regulação por catálogos, situação essa que poderia incluir até mesmo vídeo locadoras.

\subsection{O RELATÓRIO DE LUSTOSA}

Durante três meses e meio, entre 16 de setembro e 2 de dezembro de 2009, o novo relator da CCTCI, Henrique Lustosa (PMDB-CE), chegou às redação e negociação finais sobre as cotas na programação e empacotamento. Sob continua participação da Ancine e consultores legislativos, foi mantida a obrigação presente no relatório de Bittar de que todos os canais de espaço qualificado deveriam veicular três horas e trinta minutos semanais de conteúdo nacional em horário nobre: "Entendemos que, em longo prazo, o estabelecimento de obrigações de veiculação de conteúdo brasileiro apenas no horário nobre terá efeito sobre todo o restante da grade de programação"). ${ }^{96}$

Quanto à destinação na metade da reserva, ou seja, uma hora e quinze minutos semanais, à produção independente, a justificativa do documento foi de contrabalancear o estímulo a novos atores no mercado com a valorização da produção tradicional das emissoras de televi-

94 A regulamentação do conceito de coligação também está presente na Lei Art. $2^{\circ}$ Inciso V : “Coligada: pessoa natural ou jurídica que detiver, direta ou indiretamente, pelo menos $20 \%$ (vinte por cento) de participação no capital votante de outra pessoa ou se o capital votante de ambas for detido, direta ou indiretamente, em pelo menos $20 \%$ (vinte por cento) por uma mesma pessoa natural ou jurídica, nos termos da regulamentação editada pela Agência Nacional de Telecomunicações - Anatel” (BRASIL, 2011).

95 A Globo Filmes utilizou os mecanismos de renúncia fiscal nas seguintes obras entre 1995 e 2012: Zoando na TV (1999), O Auto da Compadecida (2000), Caramuru - a invenção do Brasil (2001), Casseta e Planeta - seus problemas acabaram (2006), A Grande Família - o filme (2007) e Os Normais 2 (2009) (ANCINE, 2012).

96 Disponível em: < http://imagem.camara.gov.br/Imagem/d/pdf/DCD17DEZ2009.pdf\#page=412>. Acesso em: 25 jan. 2015. 
são. Dessa forma, a expectativa era a de incluir a produção oriunda da TV aberta na programação dos canais exclusivos para assinantes.

Quanto ao maior motivo das cizânias para o andamento da Lei - as cotas de empacotamento - Lustosa conseguiu chegar à redação conclusiva. A demora para aprovar o projeto começou a gerar instabilidade. No mesmo período, ocorria a I Conferência Nacional de Comunicação e cresceu a expectativa de o governo Lula estimular uma reforma regulatória nas comunicações. Qualquer mudança no cenário poderia colocar em risco a maior conquista da Globo na "Lei da TV Paga": a decisão final das teles saírem da exploração do conteúdo. A ansiedade também estava presente na Ancine, e, por tabela, nos produtores independentes, pela expectativa de aumentar o mais rápido possível as verbas para o fomento acompanhadas por alguma garantia de distribuição. Por isso, o texto, além de considerado mais claro para os especialistas, estava num contexto mais favorável para o prosseguimento nos termos a seguir, conforme é possível analisar nos artigos 17 e 18 da Lei 12.485 (BRASIL, 2011). ${ }^{97}$

Nesse desenho, a Globo teve a garantia de que, num pacote com trinta canais de espaço qualificado, dez seriam brasileiros. E, dessa vez, apenas três deveriam ser obrigatoriamente de programadora independente. No caso dos canais qualificados oriundos de radiodifusores como a Band, deveriam disputar participação no empacotamento com os canais Globosat. E, quanto aos jornalísticos, apenas um canal brasileiro poderia ter seu espaço reservado para disputar com a GloboNews. Por fim, os canais à la carte ou pay-per-view não entraram no sistema de cotas.

A defesa por maior pluralidade na TV fechada também buscou refutar novas investidas das empresas estrangeiras e teve como justificativa no relatório de Lustosa medidas adotadas por outros países a fim de evitar a concentração na programação:

97 “Art. 17. Em todos os pacotes ofertados ao assinante, a cada 3 (três) canais de espaço qualificado existentes no pacote, ao menos 1 (um) deverá ser canal brasileiro de espaço qualificado. § 1o Da parcela mínima de canais brasileiros de espaço qualificado de que trata o caput, pelo menos 1/3 (um terço) deverá ser programado por programadora brasileira independente. § 2o A empacotadora estará obrigada a cumprir o disposto no caput até o limite de 12 (doze) canais brasileiros de espaço qualificado. § 3o As empacotadoras que ofertarem pacotes dis-tribuídos por tecnologias que possibilitem distribuir, no máximo, pacotes com até 31 (trinta e um) canais de pro-gramação estarão obrigadas a cumprir o disposto no caput deste artigo até o limite de 3 (três) canais, bem como serão dispensadas do cumprimento do disposto no art. 18. § 4o Dos canais brasileiros de espaço qualificado a serem veiculados nos pacotes, ao menos 2 (dois) canais deverão veicular, no mínimo, 12 (doze) horas diárias de conteúdo audiovisual brasileiro produzido por produtora brasileira independente, 3 (três) das quais em horário nobre. § 5 $\underline{0}$ A programadora de pelo menos um dos canais de que trata o $\S 4$ ํㅡão poderá ser controlada, controladora ou coligada a concessionária de serviço de radiodifusão de sons e imagens. Art. 18. Nos pacotes em que houver canal de programação gerado por programadora brasileira que possua majoritariamente conteúdos jornalísticos no horário nobre, deverá ser ofertado pelo menos um canal adicional de programação com as mesmas características no mesmo pacote ou na modalidade avulsa de programação, observado o disposto no $§ 4^{\circ}{ }_{-}$do art. 19. 
Essa política é utilizada em outros Países, como por exemplo, os Estados Unidos, onde as operadoras do cabo não podem deter o controle sobre mais do que $40 \%$ (quarenta por cento) dos canais por elas distribuídos, e a Espanha, onde as operadoras têm de veicular ao menos $30 \%$ (trinta por cento) de canais de programadoras independentes. ${ }^{98}$

Por fim, outro ponto chave definido sob a relatoria de Lustosa foi quanto ao carregamento dos canais abertos de radiodifusão. Nesse sentido, o Art. 32 da Lei passou a adotar o conceito de may-carry quando o "apagão digital” extinguir a exploração analógica em definitivo em 2016. Ao contrário do must-carry, o conceito de may-carry desobriga as distribuidoras a carregar automaticamente os canais abertos. O parágrafo $12^{\circ}$ do Art. 32 estabelece uma negociação entre as partes quanto os valores pagos, todavia $013^{\circ}$ permite ao radiodifusor solicitar a obrigatoriedade, caso não cheguem ao consenso.

\subsection{OS ÚLTIMOS PASSOS ATÉ SANCIONAR A LEI}

Após sair da CCTCI, o PL 29 seguiu para a Comissão de Constituição, Justiça e Cidadania (CCJC), e, no dia 12 de dezembro de 2009, o deputado federal Eduardo Cunha (PMDB-RJ) foi designado como relator. Durante seis meses, administrou-se a tensão quanto à possibilidade de o projeto seguir para plenário, e entrar numa agenda incontrolável da Câmara dos Deputados. ${ }^{99}$ Enquanto isso, os pedidos de inconstitucionalidade se tornaram objeto de pressão na Comissão, conforme expostos no relatório final de Cunha, ratificado no dia 15 de maio de 2015. ${ }^{100}$ A CCJC deu parecer favorável, porém o relator acrescentou um ponto de interesse das bancadas evangélica e católica: priorizar ao menos um canal religioso em cada localidade nas decisões da Anatel relativas aos canais de carregamento obrigatório (parágrafo $9^{\circ}$ do Art. 32 da Lei 12.485).

Terminada a trajetória na Câmara, o projeto seguiu para o Senado e mudou a nomenclatura para Projeto de Lei da Câmara 116/2010, mais conhecido como PLC 116. O primeiro relator, então senador, que depois seria cassado por corrupção, Demóstenes Torres (DEM-GO) assumiu as atribuições no dia 5 de julho de 2010 e viabilizou a realização de mais duas audiências públicas até o fim do mesmo ano, em conjunto com as Comissões de Assuntos Econô-

98 _Disponível em: $<$ http://imagem.camara.gov.br/Imagem/d/pdf/DCD17DEZ2009.pdf\#page=412 $>$. Acesso em 25 jan. 2015.

99 PAES, José de Souza Filho (Tito); NAZARENO, Claudio. Entrevista VI. [set.2014]. Entrevistador: Pedro Andrade Caribé. Brasília, 1 arquivo .mp4 (49 min).

100 Disponível em: $<$ http://imagem.camara.gov.br/Imagem/d/pdf/DCD15MAI2010.pdf\#page=273 $>$. Acesso em 25 jan. 2015. 
micos; Educação, Cultura e Esporte; Meio Ambiente, Defesa do Consumidor e Fiscalização e Controle; e Ciência, Tecnologia, Inovação, Comunicação e Informática.

No dia 15 de fevereiro de 2011, mais um relator, Eunício Oliveira (PMDB-CE), assumiu a coordenação e sua primeira iniciativa foi realizar mais uma audiência pública em parceria com as mesmas Comissões articuladas nos trabalhos de Demóstenes. Até que, no dia 30 de junho de 2011, o senador Romero Jucá (PMDB-RR) protocolou pedido de urgência para apreciação da matéria.

Após onze adiamentos em sessões na $\mathrm{CCJ}$, o projeto foi encaminhado à Secretaria Geral da Mesa do Senado no dia 15 de agosto de 2011, então presidido por José Sarney (PMDB-AP). Um dia depois, o PLC 116 foi colocado em votação com a relatoria no plenário a cargo de Walter Pinheiro (PT-BA). O relator se deparou com vinte emendas a serem analisadas, oito oriundas da CCJ e doze no plenário, antes de iniciar a votação. Acatou apenas uma de autoria própria, responsável por revisão textual na seção dedicada à cobrança do Condecine.

O parlamentar que puxou o maior número de emendas, solicitando alterações profundas no texto foi Álvaro Dias (PSDB-PR). Ele não aceitou o parecer de Walter Pinheiro e encaminhou uma das emendas, a de $n^{\circ} 16$, para votação. Foi rejeitada por 33 presentes na sessão, e aprovada por 21, entre os quais os correligionários Aécio Neves (PSDB-SP) e Aloysio Nunes (PSB-SP). ${ }^{101}$ E, assim, terminou a participação do Congresso Nacional na formulação da Lei. Na Presidência da República, houve apenas um e pouco significativo veto determinado por Dilma Rousseff: o Art. 11 que trata da Classificação Indicativa ficou sem o parágrafo $4^{\circ}$ que dava autonomia às programadoras quanto aos critérios e formas de divulgação dos conteúdos. A sanção se deu no dia 12 de setembro de 2011. ${ }^{102}$

\subsection{OS DIREITOS AUTORAIS}

$\mathrm{Na}$ avaliação dos consultores legislativos entrevistados, leis com tamanha envergadura e tamanho costumam ser encaminhadas via iniciativa do Executivo. E, de fato, na maioria das leis resgatadas neste trabalho, a exemplo da LGT, EBC, Ancine, Decreto da TV Digital e

101 Votação do dia 16 de agosto de 2011. Disponível em:

$<$ http://www.senado.gov.br/atividade/materia/mate/votacao.asp?ct=1838710 >. Acesso em: 28 jan. 2015.

$102 \mathrm{O}$ Supremo Tribunal Federal (STF) julga três Ações de Diretas de Inconstitucionalidade para vetar a Lei 12.485/2011 movidas pelo partido Democratas (ADI 4679), pela Associação NEOTV, (ADI 4747), e pela ABRA (ADI 4756). Disponível em: < http://www.stf.jus.br/portal/cms/verNoticiaDetalhe.asp? idConteudo=231843>. Acesso em: 28 jan. 2015. 
Lei do Audiovisual, o Congresso ficou responsável por reajustes. A exceção foi a da Lei do Cabo. Para ambos, no Brasil, os atores envolvidos querem determinar todos os critérios da sua atuação ainda na Lei, enquanto o mais corriqueiro é deixar para os órgãos aptos pela regulamentação a adequação dentro de princípios estabelecidos. ${ }^{103}$

Isso não significa que a Lei respondeu a todos os conceitos postos. Coube à Ancine abrir consultas públicas e especificar ponto por ponto sua responsabilidade regulatória, por meio da Instrução Normativa 100, oficializada no dia 12 de junho de 2012. Somente a partir de então pode-se acompanhar questões especificas referentes ao cumprimento das cotas, delimitar ainda mais o que é conteúdo brasileiro, o que é uma obra de ficção, seriada, conteúdo erótico, ou o que é programa de auditório. Alex Patêz ${ }^{104}$ relata que algumas brechas de interpretação da Lei ficaram sob responsabilidade da regulamentação, a exemplo do Art. 18 que trata do empacotamento dos canais jornalísticos. Nessa situação, havia possibilidade de o segundo canal ser tratado como avulso, o que foi rechaçado pela agência.

O ponto que ele considerou mais denso foi a introdução do conceito de Poder Dirigente sobre as obras. A decisão buscou suprir um vácuo legal no país, devido à falta de atualização da Lei de Direitos Autorais (LDA), a Lei 9.610/1998. Ela tem como cerne tratar dos direitos do autor (criador) e conexos (aqueles que possam deter direitos de exploração sobre a obra). No caso das obras audiovisuais, a LDA determina que os direitos econômicos são administrados diretamente pelos produtores, ${ }^{105}$ e apenas a radiodifusão é considerada especificamente no Art. $95^{\circ}$, com o intuito de "autorizar ou proibir a retransmissão, fixação e reprodução de suas emissões, bem como a comunicação ao público, pela televisão, em locais de frequência coletiva" (BRASIL,1998).

No ano de 2010, o MinC chegou a abrir uma consulta pública a fim de reformular a LDA, num processo semelhante ao Marco Civil da internet.

No entanto, quando Dilma Rousseff foi eleita, em 2010, o processo de reforma dos direitos autorais sofreu seu primeiro baque. Para suceder Juca Ferreira como seu Ministro da Cultura, Rousseff indicou Ana de Hollanda, uma cantora com relações próximas à indústria fonográfica e ao ECAD - um dos maiores adversários do anteprojeto. Foi bastante representativo de sua nova postura frente a direitos autorais que uma de suas primeiras medidas tenha sido remover as licenças Creative Commons do site do Ministério da

103 Cabe salientar que, durante a coleta de material, as consequências de tais ADINs foram minimizadas pelos entrevistados. PAES, José de Souza Filho (Tito); NAZARENO, Claudio. Entrevista VI. [set. 2014]. Entrevistador: Pedro Andrade Caribé. Brasília, 1 arquivo .mp4 (49 min).

104 PATÊZ, Alexander. Entrevista IX. [dez. 2014] Entrevistador: Pedro Andrade Caribé. Rio de Janeiro, 2014. 1 arquivo $\mathrm{mp} 4$ (72 $\mathrm{min})$.

105 Somente com a "Lei da TV Paga" (12.485/2011), definiram-se maiores critérios para classificar a produção e programação independente, e também impôs-se dura restrição para operadores de telecomunicações deterem direitos em conteúdos audiovisuais no país. 
Cultura. Logo depois, Ana de Hollanda substituiu a maior parte das pessoas que trabalhavam para a Diretoria de Direitos Intelectuais do MinC, e praticamente pôs um fim ao processo de reforma, apesar de ter empreendido uma revisão do texto. (VALENTE; MIZUKAMI, 2014, s.p.) ${ }^{106}$

Passados quinze anos da LDA, o audiovisual no país detinha etapas na circulação mais estabelecidas, bem como, uma agência reguladora específica para tratar do tema, porém sem a responsabilidade formal da legislação, muito menos, parâmetros atualizados a fim de proteger a produção brasileira e independente, financiada, basicamente, por recursos públicos. Ainda assim, a Ancine, desde criação, tentou avançar nas áreas sob sua responsabilidade. A regulamentação na destinação da Condecine, por meio da Lei 10.454 (BRASIL, 2002), determinou que conteúdo brasileiro é aquele dirigido por nativos, ou estrangeiros residente há mais de três anos no país, e sob utilização de no mínimo dois terços de artistas e técnicos brasileiros ou residentes há mais de cinco anos. No caso de co-produção, o dispositivo assegura que no mínimo $40 \%$ dos direitos patrimoniais deve ser de produtora brasileira ${ }^{107}$.

A destinação de recursos continuou a ser algo que exigia o aperfeiçoamento dos direitos autorais na criação do FSA. Dois programas básicos do fundo, o Programa de Apoio ao Desenvolvimento do Cinema (PRODECINE) e o Programa de Apoio ao Desenvolvimento do Audiovisual (PRODAV), passaram a privilegiar a produção independente. O direito patrimonial, nesses casos, era a orientação jurídica para classificar o caráter nacional e independente dos negócios, e já na Lei da Tv Paga se avançou na delimitação do que é uma produtora e programadora brasileira e independente.

Os vácuos permaneciam, e principalmente na conceituação do direito patrimonial. Por isso, foram referências como as de Sérgio Branco (2011) ${ }^{108}$ que permitiram à Ancine tentar ir além: "O direito patrimonial não quer dizer muita coisa, você pode ceder a receita para outrem" (PATÊZ, 2014, informação oral). Assim, era preciso um instrumento que permitisse aos produtores independentes maior incidência sobre um patrimônio peculiar, não proprietário, conforme é possível ver no inciso XLIX do Art. 7 da IN 100:

XLIX - Poder Dirigente sobre o Patrimônio da Obra Audiovisual: poder de controle sobre o patrimônio da obra audiovisual, constituído por intermédio da detenção majoritária dos direitos patrimoniais da mesma, condição que

106 Disponível em: <http://www.creativecommons.org.br/blog/copyright-week-pt/>. Acesso em: 28 jan. 2015.

107 Outros pontos conceituados pela Lei 10.454/2002 que impactam as negociações de direitos autorais foram: a delimitação do que é uma minissérie, programadora, programa nacional e programa internacional.

$108 \_$_Branco defende que o caráter da propriedade deve ser mensurado a partir da composição do objeto, e, no caso dos imateriais, estes podem ser copiados e utilizados por mais de um indivíduo, têm perpetuidade limitada e, a partir de um momento, não pertencem a ninguém, e, por fim, o autor sempre estará associado à obra. Dessa feita: "acreditamos que os direitos patrimoniais, que autorizam ao autor fazer uso econômico de sua obra não podem ser classificados como direito de propriedade” (BRANCO, 2011, p. 68). 
permite ao detentor ou detentores utilizar, fruir e dispor da obra, bem como explorar diretamente ou outorgar direitos para as diversas modalidades de exploração econômica da obra ou de seus elementos derivados, condicionado a que a outorga, limitada no tempo, não descaracterize a titularidade e a detenção deste poder. (BRASIL, 2012)

\subsection{A REDE É NORMATIZADA}

Durante a Copa do Mundo de 2014, às vésperas das eleições, a presidenta Dilma Rousseff anunciou o Programa Brasil de Todas as Telas, que visa destinar R\$ 700 milhões para fomento e difusão de produções nacionais. Segundo reportagem no portal O Globo, ${ }^{109}$ ela solicitou que os diretores enviassem vídeos para o Palácio da Alvorada, pois o cargo a impossibilitava de ir ao cinema. Na matéria, Dilma não cita a TV por assinatura ou aberta para acessar o conteúdo. Na ocasião, o apresentador da cerimônia era o galã Cauã Reymond, mais conhecido nas novelas e séries da TV Globo. A presidenta quebrou o protocolo e o cumprimentou antes do vice-presidente Michel Temer arrancando risos e aplausos da plateia. ${ }^{110}$

Já a então ministra da Cultura, Marta Suplicy, declarou ao Estado de São Paulo ${ }^{111}$ que os recursos dariam forças para ocupar as cotas criadas com a Lei da TV Paga, e, dessa forma, alcançar o objetivo de tornar o país entre os cinco maiores produtores e programadores de conteúdo do mundo. Dilma e Marta não deram informações conflitantes, elas podem assistir ao galã por plataformas diferentes: cinema, TV por assinatura e até TV aberta. Porém, os recursos são oriundos do mesmo lugar, o FSA, que, por sua vez, tem sua base financeira ampliada na mesma Lei da TV Paga costurada no Congresso Nacional e sancionada pela presidência em 2011.

Durante o desenvolvimento desta pesquisa, foi possível depararmo-nos com cenários influenciados pela Lei da TV Paga. O Programa Brasil de Todas as Telas, por exemplo, foi apenas lançado, e seus resultados precisam de tempo para serem executados e avaliados. Dessa forma, ainda não é possível realizar um estudo preciso sobre os efeitos no audiovisual brasileiro. Por isso, veremos alguns apontamentos em continuidade sobre a descrição da rede, e que objetivam, principalmente, servir como suporte para futuras pesquisas sobre o tema.

O apontamento inicial é relativo aos recursos arrecadados na Condecine. A Condencine-Títulos, presente desde 2002, é repassado para a administração do Fundo Nacional de 109 Disponível em: < http://linkis.com/m.oglobo.globo.com/c/8kek0>. Acesso em: 14 jul. 2014.

110 Vídeo "Cauã Reymond faz Dilma quebrar protocolo". Disponível em: < https://www.youtube.com/watch? $\mathrm{v}=$ ZKm2om9BtuQ $>$ Acesso em: 14 jul. 2014.

111 Disponível em: <http://cultura.estadao.com.br/noticias/cinema,governo-lanca-programa-brasil-de-todas-astelas, 1521847>. Acesso em: 14 jul. 2014. 
Cultura e alocado no FSA. Seu aumento é progressivo ao aumento de obras audiovisuais em circulação em quaisquer plataformas de distribuição no país. Entre 2011 e 2013, ele praticamente dobrou, passando de R $\$ 42$ para R 84 milhões. Esse crescimento representa um aquecimento do mercado e também modificações diretas oriundas dos mecanismos de arrecadação presentes na Lei $12.485 .^{112}$

Já a Condecine-Remessas é relativo à junção entre os artigos 32 e 39 da MP 2.228, e, por meio de "chantagem fiscal", permite às programadoras estrangeiras investirem em coproduções. Entre 2011 e 2013, este saltou de R\$ 1,2 para R\$ 10,9 milhões. Esse recurso não é repassado para o FSA, porém, fica sob fiscalização da Ancine. O aumento representa maior interesse dos canais estrangeiros em associar sua grade ao conteúdo nacional e independente.

A terceira, a Condecine-Teles, é novidade exclusiva da Lei 12.485 e passa a ser alocado no FSA. No ano de 2013, chegou a R\$ 711,56 milhões, conforme está sistematizado na tabela abaixo.

Tabela 3 - Recursos do Condecine por fontes de arrecadação

\begin{tabular}{lrrr}
\multicolumn{1}{c}{ Seguimento } & \multicolumn{1}{c}{$\mathbf{2 0 1 1}$} & $\mathbf{2 0 1 2}$ & $\mathbf{2 0 1 3}$ \\
\hline Condecine-Títulos & $\mathrm{R} \$ 42.467 .544$ & $\mathrm{R} \$ 64.576 .514$ & $\mathrm{R} \$ 84.156 .782$ \\
Condecine-Remessas & $\mathrm{R} \$ 1.231 .283$ & $\mathrm{R} \$ 5.088 .092^{113}$ & $\mathrm{R} \$ 10.949 .724$ \\
Condecine-Teles & (não havia sido criado) & $\mathrm{R} \$ 655.667 .562$ & $\mathrm{R} \$ 711.561 .365$ \\
Total & $\mathrm{R} \$ 43.698 .828$ & $\mathrm{R} \$ 725.332 .169$ & $\mathrm{R} \$ 806.667 .872$ \\
\hline
\end{tabular}

Fonte: Sistema Integrado de Administração Financeira do Governo Federal - SIAFI, com adaptações.

Os valores arrecadados via Condecine não seguem diretamente para os projetos audiovisuais. Primeiro, o Comitê Gestor do FSA elabora um plano para utilização dos recursos, divide os montantes por linhas, abre chamadas públicas, seleciona determinados projetos e, após o cumprimento de contrapartidas, repassa aos destinatários as verbas.

A Tabela 4 mostra os valores em Reais destinados para as linhas de ação entre 2011 e 2013. ${ }^{114} \mathrm{O}$ total salta de $\mathrm{R} \$ 79,68$ para $\mathrm{R} \$ 142,48$ milhões, como se pode verificar.

Tabela 4 - Recursos por linha de ação

\begin{tabular}{rcc}
\hline Linhas de Ação & 2011 & 2013 \\
\hline Produção de Cinema_Linha A & R\$ 34.000 .000 & R\$ 50.000.000
\end{tabular}

$112 \mathrm{O}$ artigo 33 da MP 2.228/2001 foi alterado, a fim de taxar a circulação a cada doze meses por segmento de mercado veiculado (salas de exibição, radiodifusão, SeAC, vídeo doméstico e outros); também retiraram-se isenções nas peças publicitárias reproduzidas em programação internacional.

113 No ano de 2012, foram recolhidos R\$ 39.521.579,44 via Art. 39 da MP 2.228/2001 (ANCINE, 2012).

$114 \mathrm{O}$ ano de 2012 foi de restruturação do FSA devida à efetivação da "Lei da TV Paga" e o programa "Cinema Perto de Você", por isso, as comparações mais objetivas com o ano de 2011. 
Produção de Cinema via distribuidor_Linha C

Fonte: Relatório de Gestão do FSA 2013, com adaptações. ${ }^{115}$

Há diferença substantiva entre a destinação e a contratação e o desembolso, ou seja, a seleção e o repasse de recursos diretamente para aos pleiteantes. O Prodav e o Prodecine juntos chegaram a R \$ 47 milhões desembolsados em 2013, um valor muito aquém dos R\$ 142 milhões destinados, ou mesmo dos cerca de R 700 milhões arrecadados no Condecine em 2012. Nessa perspectiva, ainda na seleção para produção, é necessário apresentar um plano envolvendo a captação de ao menos $40 \%$ da obra por outras fontes, bem como garantias de distribuição. Já, para ser embolsado, o proponente deve comprovar ter $80 \%$ dos custos totais garantidos em relação ao orçamento de produção dos projetos nas Linhas A, B e C e de 100\% do orçamento de comercialização na Linha D.

Tabela 5 - Recursos reservados à contratação do FSA

\begin{tabular}{rrrrr}
\hline & Recursos para contratação & Projetos contratados & Recursos desembolsados \\
\hline $\mathbf{2 0 1 1}$ & R $\$ 48.239 .783$ & 54 & R $\$ 31.147 .930$ \\
$\mathbf{2 0 1 3}$ & R $\$ 85.740 .894$ & 88 & R $\$ 47.176 .224$ \\
\hline
\end{tabular}

Fonte: Relatório de Gestão do FSA 2013, com adaptações. ${ }^{116}$

Além do longo processo para destinar os recursos às atividades finalísticas, o FSA ainda enfrenta a dificuldade para cumprir a obrigação da Lei de distribuir 30\% do montante do Condecine para produtoras do Norte, Nordeste e Centro-Oeste. Tal desigualdade é histórica dos mecanismos de financiamento. Segundo levantamento do jornal Folha de São Paulo, dez produtoras concentram 34\% das verbas para filmes nacionais entre 1995 e 2002. As dez só re-

115 Disponível em: <http://fsa.ancine.gov.br/sites/default/files/relatorios-de-gestao/Relat $\% \mathrm{C} 3 \% \mathrm{~B} 3$ rio\%20de $\% 20$ Gest $\%$ C3\%A30\%20FSA $\% 202013 \% 20-\% 20 \%$ C3\%BAltima $\% 20$ vers $\%$ C3\%A3o.pdf >. Acesso em: 28 jan. 2015.

116 Disponível em: $<$ http://fsa.ancine.gov.br/sites/default/files/relatorios-de-gestao/Relat $\% \mathrm{C} 3 \% \mathrm{~B} 3$ rio $\% 20 \mathrm{de} \% 20$ Gest $\%$ C3\%A30\%20FSA\%202013\%20\%20\%C3\%BAltima\%20vers\%C3\%A3o.pdf $>$. Acesso em: 28 jan. 2015. 
presentam $2 \%$ do universo de quatrocentas que conseguiram captar nesse período. ${ }^{117}$ Todavia, esse quadro persistiu durante a presidência de Manoel Rangel. Entre os vinte e sete estados e o Distrito Federal, apenas dez tiveram produtoras contempladas entre 2011 e 2013. Para completar, a concentração se manteve nos estados do Rio de Janeiro e São Paulo. Veja-se a Tabela 6 que segue:

Tabela 6 - Recursos do FSA por Unidade Federativa

\begin{tabular}{crrr}
\hline UF & \multicolumn{1}{c}{$\mathbf{2 0 1 1}$} & $\mathbf{2 0 1 2}$ & \multicolumn{1}{c}{$\mathbf{2 0 1 3}$} \\
\hline $\mathrm{BA}$ & $\mathrm{R} \$ 1.363 .000$ & & $\mathrm{R} \$ 2.472 .355$ \\
$\mathrm{DF}$ & $\mathrm{R} \$ 500.000$ & $\mathrm{R} \$ 750.373$ & $\mathrm{R} \$ 2.500 .000$ \\
$\mathrm{MG}$ & $\mathrm{R} \$ 1.450 .000$ & & $\mathrm{R} \$ 1.010 .512$ \\
$\mathrm{~PB}$ & $\mathrm{R} \$ 900.000$ & & \\
$\mathrm{PE}$ & $\mathrm{R} \$ 748.000$ & & $\mathrm{R} \$ 400.000$ \\
$\mathrm{PR}$ & $\mathrm{R} \$ 2.000 .000$ & $\mathrm{R} \$ 3.615 .842$ & $\mathrm{R} \$ 1.475 .000$ \\
$\mathrm{RJ}$ & $\mathrm{R} \$ 46.590 .000$ & & $\mathrm{R} 62.949 .536$ \\
$\mathrm{RS}$ & $\mathrm{R} \$ 3.800 .000$ & & $\mathrm{R} \$ 1.923 .281$ \\
$\mathrm{SC}$ & & $\mathrm{R} \$ 5.450 .000$ & $\mathrm{R} \$ 72.048 .000$ \\
$\mathrm{SP}$ & $\mathrm{R} \$ 22.329 .000$ & $\mathrm{R} \$ \mathbf{9 . 8 1 6 . 2 1 5}$ & $\mathrm{R} \$ \mathbf{1 4 5 . 0 7 8 . 6 9 2}$ \\
\hline Total & $\mathrm{R} \$ \mathbf{7 9 . 6 8 0 . 0 0 0}$ & & \\
\hline
\end{tabular}

Fonte: Relatório de Gestão do FSA 2013, com adaptações. ${ }^{118}$

A partir de 2013, a Ancine e o FSA anunciaram uma série de medidas para reverter os gargalos na destinação dos recursos, embora não seja possível avaliar a eficácia dos dispositivos. Quanto às disparidades entre as Unidades da Federação, o orçamento para o biênio 2013/2014 reservou R\$ 80 milhões ${ }^{119}$ com a rubrica “Suplemento Regional”. Nesse mecanismo, o FSA repassa a instituições locais (prefeituras e governos estaduais) um valor que pode ser até duas vezes superior ao alocado por essas instituições nas regiões Norte, Nordeste e Centro-Oeste; e até uma vez e meia superior aos valores aportados na região Sul e nos estados de Minas Gerais e Espírito Santo. ${ }^{120}$

Nesses casos, as instituições locais têm autonomia para desenvolver critérios no repasse das verbas sem passar por trâmites corriqueiros do FSA. ${ }^{121}$ Isso, porque não surtiu os

117 FRANCO, Luiza; PORTO, Walter. Dez produtoras concentram 34\% das verbas para filmes nacionais. Folha de São Paulo, 31 jul. 2014.

118 Disponível em: <http://fsa.ancine.gov.br/sites/default/files/relatorios-de-gestao/Relat $\%$ C3\%B3rio\%20de \%20Gest $\%$ C3\%A30\%20FSA $\% 202013 \% 20-\% 20 \% \mathrm{C} 3 \%$ BAltima $\% 20$ vers $\% \mathrm{C} 3 \% \mathrm{~A} 30 . \mathrm{pdf}>$. Acesso em: $28 / 01 / 2015$

119 Disponível em: <http://fsa.ancine.gov.br/resultados/investimentos/investimentos-linhas-acao $>$. Acesso em: 28 jan. 2015.

120 Disponível em: < http://www.ancine.gov.br/sala-imprensa/noticias/fundo-setorial-do-audiovisual-investe-r50-milh-es-em-suplementa-o-de-recur-0 >. Acesso em: 28 jan. 2015.

121 No Rio Grande do Sul, foram destinados R\$ 5 milhões, sendo R\$ 3 milhões do FSA. (Disponível em: $<$ http://www.ccmq.com.br/2014/08/29661/>. Acesso em: 28 jan. 2015. 
efeitos esperados a decisão do Comitê Gestor de reduzir a comprovação da captação de $40 \%$ para $30 \%$ do valor previsto para o orçamento de produção no caso de projetos de empresas produtoras sediadas em Unidades da Federação diferentes de Rio de Janeiro e São Paulo. No mesmo biênio, mais oito linhas foram abertas no FSA, totalizando R\$ 223 milhões, conforme a Tabela 7 que segue.

Tabela 7 - Investimentos disponibilizados para as linhas de ação de produção e distribuição

\begin{tabular}{lc}
\multicolumn{1}{c}{ Linha/Ação 2013/14 } & $\begin{array}{c}\text { Valor } \\
\text { (em milhões) }\end{array}$ \\
\hline Produção Cinematográfica - inovação de linguagem & $\mathrm{R} \$ 20$ \\
Desenvolvimento - núcleos criativos & $\mathrm{R} \$ 18$ \\
Desenvolvimento - projetos & $\mathrm{R} \$ 5$ \\
Desenvolvimento - projetos via laboratórios & $\mathrm{R} \$ 10$ \\
Suporte Automático & $\mathrm{R} \$ 40$ \\
Cinema Perto de Você* & $\mathrm{R} \$ 35$ \\
Produção de Tv - programadora & $\mathrm{R} \$ 60$ \\
Suplemento Regional & $\mathrm{R} \$ 80$ \\
& Total \\
\hline
\end{tabular}

Fonte: FSA/Ancine, com adaptações. ${ }^{12}$

(*) Dos recursos orçamentários de 2013, foram destacados R\$ 35 milhões para o Programa "Cinema Perto de Você", cujo valor total previsto é de até $\mathrm{R} \$ 300$ milhões de reais para crédito e investimento e de $\mathrm{R} \$ 146$ milhões para digitalização do par que exibidor.

A linha/ação "Produção de TV - programadora" tem como objetivo responder ao Art. 27 da Lei 12.485, que determina o repasse de $10 \%$ dos recursos do Condecine ao fomento da produção de conteúdo independente veiculado primeiramente nos canais comunitários, universitários e de programadoras brasileiras independentes. No caso baiano, os recursos oriundos dessa linha foram associados ao Instituto de Radiodifusão Educativa da Bahia (Irdeb), bem como o Suplemento Regional. Dessa forma, foram realizados dois editais: um para o fomento com janela de exibição garantida na TVE-Bahia; outro para licenciamento de obras audiovisuais para TVE-Bahia e Portal Irdeb. ${ }^{123}$

\subsubsection{As cotas na programação e empacotamento}

A partir da data de publicação da Lei 12.485, em 12 de setembro de 2011, as cotas para conteúdo brasileiro na programação e empacotamento têm vigência por doze anos. No

122 Atualizado em 08 jan. 2015. Disponível em:

$<$ http://fsa.ancine.gov.br/resultados/investimentos/investimentos-linhas-acao $>$. Acesso em: 28 jan. 2015.

123 Disponível em: < http://www.irdeb.ba.gov.br/projetosespeciais/editais/13339-editais > Acesso em: 28 jan. 2015. 
Art. 23, foi acordado que, no primeiro ano, dois terços deveriam ser cumpridos, e, no segundo ano, o terço restante. Por isso, tais metas, ao serem cruzadas com as informações presentes no sítio eletrônico da Ancine, ${ }^{124}$ permitem uma análise mais criteriosa sobre esses resultados na TV por assinatura.

Até o fim de 2013, a Ancine contabilizou 98 Canais de Espaço Qualificado (CEQ) ofertados no SeAC, ${ }^{125}$ sendo 64 deles originários de empresas dos Estados Unidos. A Time Warner é a maior em atuação, com ingerência no maior número de canais, 26; entre os principais, estão Cartoon Network, TNT, Warner Channel e a rede HBO. Em segundo lugar, estão as Organizações Globo com quinze canais, entre os quais, a rede Telecine, os canais Universal Channel, Syfy, Studio Universal, GNT, Multishow, Gloob e Globosat. O terceiro é o Discovery com onze canais, dos quais, em especial, o Discovery Kids. A seguir, a tabela com as dez principais programadoras do país, levando-se em consideração o número de assinantes.

Tabela 8 - Principais programadoras da TV por assinatura

\begin{tabular}{lccc}
\hline Grupo Controlador/Programadora & Números de Canais & Número de Assinaturas & País \\
\hline Time Warner & 26 & 180.338 .347 & EUA \\
Globo & 15 & 143.968 .312 & BRA \\
\hline Discovery & 11 & 93.852 .691 & EUA \\
News Corp. (Fox) & 8 & 66.989 .289 & EUA \\
\hline Viacom & 6 & 44.100 .000 & EUA \\
\hline Sony Pictures Entertainment & 3 & 30.557 .000 & EUA \\
\hline Disney & 4 & 28.551 .728 & EUA \\
\hline NBC Universal & 3 & 26.817 .338 & EUA \\
\hline Gamecorp & 1 & 15.881 .413 & BRA \\
Band / Newco & 1 & 12.081 .215 & BRA \\
\hline
\end{tabular}

Fonte: Informe da TV Paga, Ancine/SAM. O Mercado de TV por Assinatura no Brasil em 2013. Converge Comunicações; Sistema Ancine Digital, com adaptações.

Ao levar em consideração vinte canais qualificados em 2013, a Ancine identificou o predomínio da ficção com $82,4 \%$ no computo total da programação. A partir de então, três grupos de canais são sistematizados no estudo em relação ao predomínio do conteúdo: (I) Obras/Programas Seriados do tipo Ficção; (II) “Canais de Filmes” (Longa-Metragem, Anima-

124 Disponível em: < http://www.ancine.gov.br/>. Acesso em: 2 fev. 2015.

125 Todas as informações relativas aos Canais de Espaço Qualificado foram retiradas do relatório da Superintendência de Análise de Mercado da Ancine, que por sua vez, detém dados próprios e cruzados com a Converge Comunicações e Sistema Ancine Digital. 
ção e Documentário); (III) Canais Diversos (Obras de Ficção, Obras de Variedade Ancorada por Apresentador, Vídeo-musicais e Documentários). Tal classificação da Ancine ratifica a importância das séries na constituição desta rede audiovisual, mesmo sem predominar em termos quantitativos ou econômicos.

Tabela 9 - Perfil dos canais de espaço qualificados

\begin{tabular}{|c|c|c|c|}
\hline Canal & Obra/Programa não Seriado/a & Obra/ Programa Seriado/a & Grupo \\
\hline GNT $^{126}$ & $12,6 \%$ & $87,4 \%$ & III \\
\hline Sony & $16,3 \%$ & $83,8 \%$ & I \\
\hline $\mathbf{A X N}$ & $16,4 \%$ & $83,6 \%$ & I \\
\hline Warner Channel & $33,6 \%$ & $66,4 \%$ & I \\
\hline $\begin{array}{c}\text { Universal } \\
\text { Channel }\end{array}$ & $35,7 \%$ & $64,3 \%$ & $\mathrm{I}$ \\
\hline Multishow & $65,1 \%$ & $34,9 \%$ & III \\
\hline Canal Brasil & $65,8 \%$ & $34,2 \%$ & III \\
\hline Cinemax & $78,4 \%$ & $21,6 \%$ & II \\
\hline HBO Family & $84,2 \%$ & $15,8 \%$ & II \\
\hline HBO & $85,9 \%$ & $14,1 \%$ & II \\
\hline HBO Plus & $88,3 \%$ & $11,7 \%$ & II \\
\hline Maxprime & $94,5 \%$ & $5,5 \%$ & II \\
\hline TNT & $97,5 \%$ & $2,5 \%$ & II \\
\hline Megapix & $100 \%$ & - & II \\
\hline Telecine Action & $100 \%$ & - & II \\
\hline Telecine Cult & $100 \%$ & - & II \\
\hline Telecine Fun & $100 \%$ & - & II \\
\hline Telecine Pipoca & $100 \%$ & - & II \\
\hline Telecine Premium & $100 \%$ & - & II \\
\hline Telecine Touch & $100 \%$ & - & II \\
\hline Total & $73,5 \%$ & $26,5 \%$ & \\
\hline
\end{tabular}

126 "A grade de programação do canal GNT registrou o maior volume de horas dedicadas à veiculação de Obras de Variedades Ancoradas por Apresentador (54,8\%) e Documentários (21,8\%) e o menor volume para Obras de Ficção (18,9\%). Também estiveram presentes na programação anual do canal, as obras de Reality Show, que ocuparam 4,0\% da grade" (ANCINE/SAM, 2014, p. 23).

127 Disponível em: $<$ http://oca.ancine.gov.br/media/SAM/2013/Programacao/InformeTVPaga2013.pdf $>$ Acesso em: 28 jan. 2015. 
Já o crescimento na participação do conteúdo brasileiro nos CEQ pode ser analisado pelo número de horas veiculadas em quatorze dos principais canais: AXN, HBO, HBO Family, HBO Plus, Maxprime, Sony, Telecine Action, Telecine Cult, Telecine Fun, Telecine Pipoca, Telecine Premium, Telecine Touch, TNT e Warner Channel. O número de horas transmitidas saltou $286 \%$ entre 2011 e 2013, saindo de $1007 \mathrm{~h} 29 \min 59$ s (mil e sete horas, vinte e nove minutos e cinquenta e nove segundos) para $3884 \mathrm{~h} 00 \mathrm{~min} 02 \mathrm{~s}$ (três mil oitocentos e oitenta e quatro horas, e dois segundos). ${ }^{128}$

Figura 6 - Participação do conteúdo nacional em canais de espaço qualificado

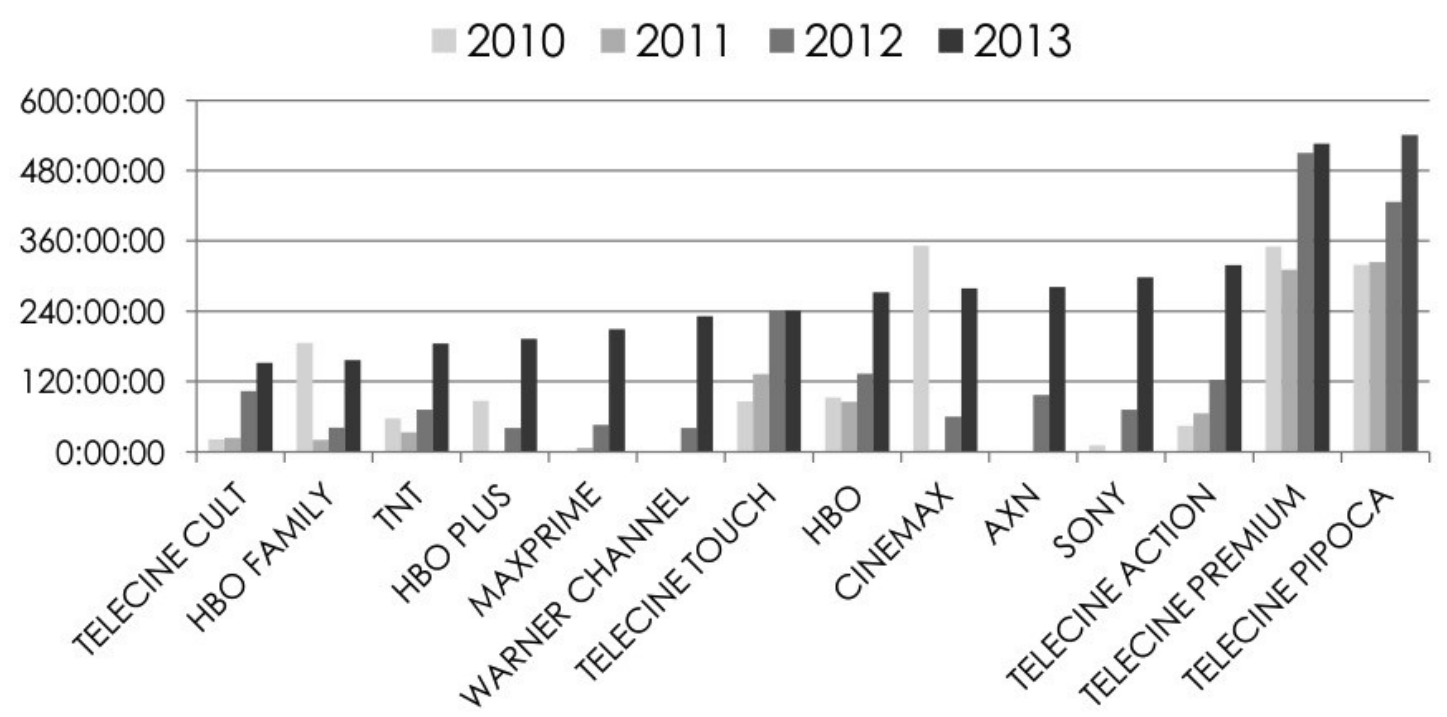

Fonte: Monitoramento Ancine/SAM, com adaptações.

Mesmo com o crescimento proporcionalmente expressivo, o montante do conteúdo brasileiro não ultrapassou os 3,5\% no total desses quatorze canais. Ainda assim, algumas programadoras solicitaram dispensa no cumprimento das obrigações à Ancine. Denise Moura (2014) analisou treze decisões da agência quanto a tais pedidos, até julho de 2014. Destes, selecionamos dois exemplos para análise.

$\mathrm{O}$ primeiro foi o indeferimento à programadora Viacom em três canais: Comedy Central, Nick Jr e Nick HD, sendo que, nesse último, o cumprimento das obrigações foi acompanhado por acordos de coprodução nacional. ${ }^{129} \mathrm{O}$ segundo foi o também indeferimento ao Canal Tooncast da Tunner Internacional, responsável por exibir animações clássicas sem

128 Ancine/SAM. Disponível em:

$<$ http://oca.ancine.gov.br/media/SAM/2013/Programacao/InformeTVPaga2013.pdf $>$. Acesso em: 28 jan. 2015.

129 São exemplos, a série Julie e os Fantasmas em parceria com a Band e a produtora brasileira Mixer, e a série Danni Who, também com a Mixer (MOURA, 2014). 
intervalo comercial, que alegou que o cumprimento de tal cota acarretaria problemas no satélite pois o sinal era transmitido de modo uniforme em toda América Latina. Porém, o aumento no número de assinantes do canal viabilizou-lhe a utilização de um sinal de satélite apenas para o Brasil, e a Turma da Mônica foi escolhida como conteúdo adequado ao perfil da programação:

Há que se reconhecer a postura da Ancine frente aos pedidos de dispensa de obrigação de veiculação de conteúdo brasileiro e seu papel no estímulo a novas produções. Como resultado dos vários pedidos de deferimento negados, muitos canais passaram a financiar a produção de conteúdo brasileiro, como relatado no caso do Nick HD. A produção nacional também passou a ser internacionalizada, por conta de fatores operacionais na distribuição do sinal, no Canal Tooncast. (MOURA, 2014, p. 14)

Outra vertente das cotas é no empacotamento, ponto de maior atrito durante a tramitação e apto para análise mais atualizada. Nesse caso, é possível fazer uma avaliação mais atualizada, conforme o documento de classificação dos canais divulgado no dia 8 de janeiro de $2015^{130}$ na página da Ancine. Foram selecionados 118 CEQs, sendo 22 Canais Brasileiros de Espaço Qualificado (CBEQ). Ao comparar com o ano de 2012, quando se iniciou a classificação oficialmente, doze novos CBEQ surgiram, numa demonstração de que havia condições para viabilizar tais empreendimentos, caso a demanda fosse apresentada.

Entre os 22 canais, a Ancine classificou quinze como independentes (CBEQI), nesse caso, os canais não são controlados, controladores ou coligados a programadora ou distribuidora no SeAC. Nessa categoria, estão excluídos seis canais associados a Globosat - Canal Brasil, Globosat, GNT, BIS, OFF, Play TV -, e o Arte 1, do grupo Band.

A terceira subdivisão é relativa aos quatro canais que veiculam, no mínimo, doze horas diárias de conteúdo audiovisual brasileiro oriundo de produtora brasileira independente, três das quais em horário nobre, denominado como Canal Super Brasileiro (SB): CineBrasilTV, Canal Brasil, Curta! e Prime Box Brasil. Por fim, a quarta categoria é quando a programadora de um Canal SB não é controlada, controladora ou coligada à concessionária de radiodifusão (SbsR), ou seja, apenas o Canal Brasil é excluído em comparação ao SB. ${ }^{131}$

A configuração entre os canais brasileiros de espaço qualificado pode sofrer uma mudança brusca, caso a Globosat invoque o direito de classificar-se como independente. Isso porque sua saída como sócio com direito a votar na NET permitiu-lhe ser enquadrada nessa

130 Disponível em: $\quad<$ http://www.ancine.gov.br/sites/default/files/classificacao-canais-programacao/listaclassificacao-canais-08012015.pdf $>$. Acesso em: 28 jan. 2015.

131 Ao tomar como parâmetro o pacote mais barato da GVT, no valor R \$ 79,00 mensais, disponível no dia 24 de janeiro de 2015, o consumidor tem direito a 38 canais, 21 deles de espaço qualificado, entre os quais sete cumpridores de todas as cotas nacionais: OFF, BIS, + Globosat, Prime Box Brasil, Fish Tv, Curta!, Arte 1. 
categoria (GINDRE, 2014). ${ }^{132}$ Todavia, o Superintendente da Ancine, Alex Patêz (informação oral), ${ }^{133}$ não acredita nessa possibilidade.

Tabela 10 - Configurações dos canais brasileiros

\begin{tabular}{|c|c|c|c|}
\hline Canais Brasileiros de Espaço Qualificado & CBEQI & SB & SbrS \\
\hline Canal Brasil & & $\mathrm{X}$ & \\
\hline Curta! & & $\mathrm{X}$ & $\mathrm{X}$ \\
\hline Cinebrasiltv & $\mathrm{X}$ & $\mathrm{X}$ & $\mathrm{X}$ \\
\hline Prime Box Brasil & $\mathrm{X}$ & $\mathrm{X}$ & $\mathrm{X}$ \\
\hline Music Box Brazil & $\mathrm{X}$ & & \\
\hline Chef TV & $\mathrm{X}$ & & \\
\hline FishTV & $\mathrm{X}$ & & \\
\hline Mundo TV & $\mathrm{X}$ & & \\
\hline Cennarium TV & $\mathrm{X}$ & & \\
\hline Mix TV & $\mathrm{X}$ & & \\
\hline Travel Box Brazil & $\mathrm{X}$ & & \\
\hline TV Climatempo & $\mathrm{X}$ & & \\
\hline Woohoo & $\mathrm{X}$ & & \\
\hline TV Rá Tim Bum & $\mathrm{X}$ & & \\
\hline Zoomoo Brasil & $\mathrm{X}$ & & \\
\hline \multicolumn{4}{|l|}{ +Globosat } \\
\hline \multicolumn{4}{|l|}{ BIS } \\
\hline \multicolumn{4}{|l|}{ GNT } \\
\hline \multicolumn{4}{|l|}{ OFF } \\
\hline \multicolumn{4}{|l|}{ Play TV } \\
\hline Arte 1 & & & \\
\hline
\end{tabular}

Fonte: Monitoramento Ancine/SAM, com adaptações.

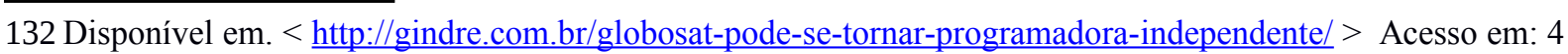
ago. 2014.

133 NAZARENO, Claudio. Entrevista VI. [set. 2014]. Entrevistador: Pedro Andrade Caribé. Brasília, 1 arquivo .mp4 (49 min). 


\subsubsection{Os vínculos da distribuição com o conteúdo}

Tido como ponto de partida para a formulação da "Lei da TV Paga", vimos que o “Tratado de Tordesilhas" seguiu caminho ressoante ao panorama da TV por assinatura. Todavia, algumas situações de participação cruzada na propriedade da cadeia permanecem, bem como, e, principalmente, estratégias coordenadas entre os grupos na programação e distribuição para manter e expandir a concentração.

As Organizações Globo continuaram o movimento de perder espaço na distribuição ainda na tramitação da Lei, ao vender 18,9\% da SkyBrasil à DirecTV, como fruto de acordo firmado em 2004, ${ }^{134} \mathrm{e}$, hoje, ela permanece com 7\% dos papéis da Sky no país. ${ }^{135}$ Quanto à Net, ainda em 2012, a Anatel autorizou o repasse das participações da Globo para a Embratel (Telmex), e também a diminuição do controle da empresa brasileira na gestão. ${ }^{136}$ só restando o controle parcial sobre a EG. Participações que detém $12 \%$ das ações da Net. ${ }^{137}$ A Bandeirantes mantém o controle da distribuidora Sim TV e os canais na programação Arte 1, Band News e BandSports. Também persistiu uma situação inversa, um grupo, que privilegia a distribuição com participação na programação, porém a Ancine interviu e tratou o caso como ilegal em maio de 2014. Nesse caso, a Sky detinha controle sobre o canal Sports + da programadora Time Out, sediada no Uruguai. ${ }^{138}$

Para além da arrecadação financeira presente no descumprimento do "Tratado", o exemplo da Globo é o mais expressivo, porque abre brechas para a continuidade da política de exclusividade ou privilégios no empacotamento. Isso, porque tal prática permanece nas principais prestadoras do SeAC, e, mais uma vez, os direitos esportivos protagonizam as atenções do púbico.

O alvo da disputa passou a se dar em torno do canal Esporte Interativo (EI). A Sky e a Net têm impedido a exibição do canal, devido a pressões da Sportv (Globosat) e ESPN (Disney), a fim de evitar concorrência já em crescimento dados os investimentos da Fox Sports. A situação se agravou com o lançamento do Esporte Interativo Nordeste, responsável por transmitir campeonatos estaduais e a Copa do Nordeste de futebol. Sem conseguir disputar com es-

134 Disponível em: < http://www1.folha.uol.com.br/fsp/mercado/me1712201034.htm $>$. Acesso em: 25 jan. 2015.

135 Disponível em: < http://gindre.com.br/conheca-as-organizacoes-globo/ > . Acesso em: 25 jan. 2015.

136 Disponível em: < http://www.meioemensagem.com.br/home/midia/noticias/2012/01/27/Net-sera-controladapela-Telmex-Embratel.html >. Acesso em: 25 jan. 2015.

137 Disponível em: < http://gindre.com.br/globosat-pode-se-tornar-programadora-independente/ >. Acesso em: 25 jan. 2015.

138 Disponível em: < http://wap.convergenciadigital.com.br/cgi/cgilua.exe/sys/start.htm?from info index=-

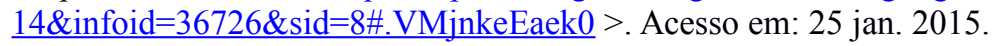


ses grupos, o EI procurou um banco de investimento internacional e conseguiu firmar uma sociedade com a Turner por R $\$ 80$ milhões em junho de 2013. A partir de então, conseguiu obter exclusividade para os direitos de exibição da Champions League entre junho de 2015 e junho de 2018, por cerca de R\$ 318 milhões, desbancando Sportv, Fox Sports e ESPN. ${ }^{139}$

Outra forma de ingerência das distribuidoras na programação é na seleção dos canais qualificados aptos a cumprir as cotas. Por exemplo, a empacotamento pode decidir por colocar o Canal Brasil e o Curta! para cumprirem a determinação dos parágrafos $4^{\circ}$ e $5^{\circ}$ do Art. 17 da Lei 12.485 (BRASIL, 2011). Nesse sentido, ao menos dois com doze horas diárias de conteúdo brasileiro oriundo de produtora independente, três das quais em horário nobre; e um não controlado, controlador ou coligado à radiodifusão (Curta!). Já o parágrafo $1^{\circ}$ do mesmo artigo, referente à presença de programadores independentes, pode ser cumprido com canais pouco expressivos, a exemplo daqueles dedicados exclusivamente à pesca (FishTV), meteorologia (TVClimaTempo) e vídeo clipes (Music Box Brasil). Enquanto isso, canais com vocação para conteúdos com maior potencial econômico como obras seriadas e longas-metragens, a exemplo do CineBrasilTV e Prime Box Brasil, podem ficar de fora dos pacotes mais populares.

Para completar, há pouca transparência sobre os contratos das operadoras com as programadoras brasileiras independentes. Tereza Trautman (ANO), diretora do CineBrasilTV, relata a continuidade nas dificuldades de sobrevivência desses canais devido à regulação da Ancine. Para ela, a falta de critérios para selecionar os canais como aptos a integrarem o sistema de cotas e a falta de intervenção nos preços baixos repassados pelos empacotadores impede o desenvolvimento desse segmento:

Conseguimos uma cota pequena. Aumentamos nossa participação em cerca de $1 \%$ no mercado. $\mathrm{O}$ audiovisual estava tão deprimido que qualquer coisa estimula. Mas a Ancine regulou mal a Lei, porque os canais foram nivelados sem corresponder a expectativa. O Canal Brasil estava como independente e exibia conteúdo da Globosat, mas não tinha fiscalização. Agora tem canais dados como cortesia numa operadora, e entrando como cota em outra. Isso fez com que as operadoras pagassem um preço fixo baixo, vergonhoso. Qualquer um que coloca conteúdo nacional em horário nobre é de cota. Se há uma bolha é "ancínica". Os canais de cotas ganham tão pouco que é quase impossível se manter, é indigente. Foi falto de preparo. Antes, a Ancine dizia que preços era responsabilidade do CADE, agora eles querem entrar no assunto balizados na IN 100. (TRAUTMAN, 2015, informação oral) ${ }^{140}$

139 Todas as informações foram relatadas pelo empresário criador do EI, Edgard Diniz ao blogueiro Cosme Rímoli. Disponível em: <http://esportes.r7.com/blogs/cosme-rimoli/2015-comeca-com-uma-briga-degigantes-para-que-o-brasileiro-assista-a-champions-league-net-e-sky-parceiras-da-sportv-e-espn-naoabriam-espaco-para-o-esporte-interativo-ate-que-chegou-a-turner-01012015/> . Acesso em: 25 jan. 2015.

140 TRAUTMAN, Tereza. Entrevista X. [jan.2015] Entrevistador: Pedro Andrade Caribé. Videoconferência, 2015. 1 arquivo .mp4 (82min). 
A relação dos distribuidores/empacotadores com a programação também pode vir por mecanismos indiretos, no caso do SeAC, por meio da concentração na atividade. Nos dados publicados pela Anatel relativos ao mês de novembro de 2014, Net/Claro/Embratel (53\%) e Sky $(28,5 \%)$ representam juntas $81,5 \%$ do mercado no país, proporção próxima aos $84,7 \%$ em 2011. ${ }^{141}$ No mesmo mês de 2014, a NeoTV protagonista de disputas por exclusividades no início dos anos 2000, comemorou quinze anos de existência, reclamando por representar 142 associados, todavia, alegam deter $4 \%$ do market share. Apesar das pequenas operadoras predominarem nas novas licenças do SeAC, entre as maiores dificuldades apontadas pelos membros da NeoTV está o aumento dos valores pagos pela programação, superiores aos contratos das grandes operadoras. ${ }^{142}$

Quanto à influência na rede audiovisual, devido ao aumento na base dos assinantes, realmente ela aconteceu nos últimos quatro anos, chegando aos 19,8 milhões de usuários em novembro de 2014, contra 12,7 milhões em 2011. ${ }^{143}$ Todavia, os sinais indicam que o crescimento não tem um forte vínculo com a adoção da "Lei da TV Paga". No mês de novembro de 2010 a edição da revista Tele Time trouxe como destaque na capa a reportagem intitulada " $\mathrm{O}$ ano da TV por assinatura" (POSSEBON, 2010, p. 8-13). Na ocasião, foi celebrado o crescimento de $21 \%$ no acumulado de janeiro a setembro, chegando a 9,5 milhões de assinantes. $\mathrm{O}$ resultado foi mais estimulado pela Embratel e pela prática de venda casada entre telefonia fixa e banda larga da Net. Ambas vieram a se juntar oficialmente em janeiro de 2012, após a Lei 12.485 (BRASIL, 2011) induzir o repasse das ações da Globo na Net para a Telmex (Embratel). ${ }^{144}$

A outra protagonista do SeAC, a Sky, rejeita publicamente a tese de que a "Lei da TV Paga" poderia impactar no aumento da distribuição. Em entrevista à revista TelaViva, após a confirmação da Lei, o principal executivo da SkyBrasil, Luiz Bap, declarou:

O preço caiu $50 \%$ em valores reais nos últimos três anos sem o governo fazer nada, e caiu porque passamos dois anos brigando com os programadores e mudamos algumas condições ruins. Todo o mundo lançou pacotes mais baratos, sem obrigações de carregamento, sem obrigações financeiras e mudamos o modelo de negócio. (POSSEBON, 2014, p. 14)

141 Disponível em: $<$ http://www.teleco.com.br $>$. Acesso em: 28 jan. 2015.

142 Disponível em: $<$ http://convergecom.com.br/telaviva/paytv/26/11/2014/aos-15-neotv-ve-mercado-maisconcentrado/\#.VMkRHeEaek0>. Acesso em: 28 jan. 2015.

143 Disponível em: $<$ http://www.teleco.com.br $>$. Acesso em: 25 jan. 2015.

144 Disponível em: < http://www.meioemensagem.com.br/home/midia/noticias/2012/01/27/Net-sera-controladapela-Telmex-Embratel.html $>$. Acesso em: 25 jan. 2015. 
Figura 7 - Market share da distribuição no SeAC

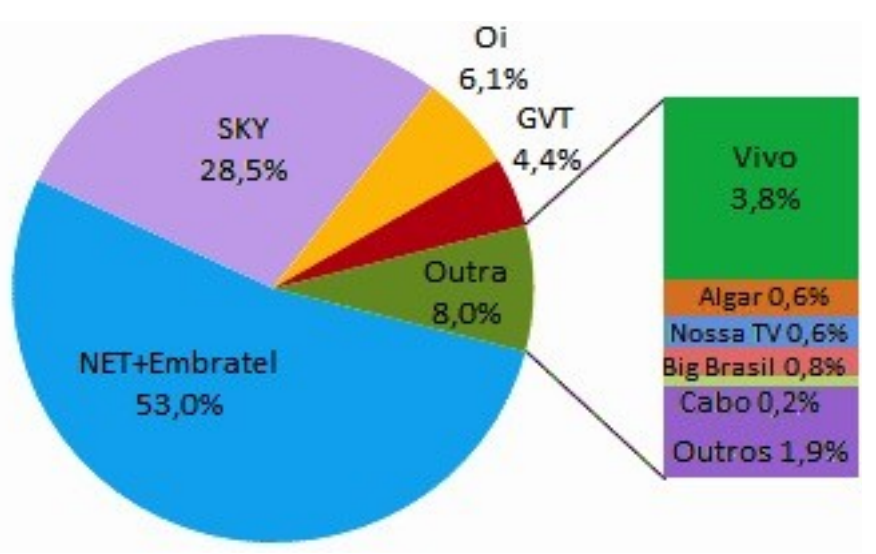

Fonte: Teleco - inteligência em telecomunicações. ${ }^{145}$

\subsection{OS TRANSBORDAMENTOS}

O período denominado como Retomada do Cinema Brasileiro teve como uma das suas marcas as "bolhas" no mercado audiovisual nacional. Os recursos depositados a partir da renúncia fiscal e o glamour das premiações internacionais insuflaram o segmento sem medidas complementares na distribuição das salas de exibição ou mesmo com a TV aberta. Um desses estouros se cruzou com a crise nos grupos de mídia nacional, em especial a TV aberta, entre 2001 e 2005. No caso da rede constituída com a "Lei da TV Paga", os atores envolvidos apontam os caminhos que a rede transborda e se fazem necessárias adequações regulatórias.

O temor da nova crise não assusta o diretor da ABPITV e membro do Comitê Gestor do FSA, Mauro Garcia. Ele se baliza no aumento do número de assinaturas na TV paga e a familiaridade desse público com o conteúdo nacional, presente na TV aberta:

A TV aberta é produto brasileiro. E aí os canais de TV por assinatura, principalmente estrangeiros, têm que dublar suas séries, o que se tornou comum. As séries brasileiras estão em horário nobre não apenas por exigência da lei,

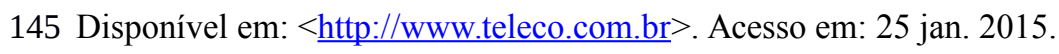


mas para fidelizar o usuário. A quantidade ocupada pela série nacional já está além da conta. A lei veio sintonizada com um movimento de mercado, e pode servir para cenários futuros. A Globo e Band já têm distribuidoras própria de conteúdo. A G2C distribui todo conteúdo com chancela da Globo para todas as plataformas. Quando ela sente que está pronta ela tira as travas. (GARCIA, 2014, informação oral)

Para o jornalista Samuel Possebon, o aumento das fontes de fomento e as reservas na programação ainda compõem um arranjo econômico frágil para a TV por assinatura para continuar o crescimento do mercado. Primeiro devido à dependência dos canais ao conteúdo fomentado pela Ancine, e segundo, à vagarosidade no repasse dos recursos do FSA. Segundo ele:

Hoje, tem quantidade grande de produtores independentes na tv por assinatura. Mas ainda não chegou ao equilíbrio econômico. Eles fazem para tv por assinatura, mas o preço é muito abaixo do preço de custo. Se for cobrar o conteúdo brasileiro, devido aos custos globais mais altos, se for cobrar esse preço, esses conteúdos custariam uma fortuna. Isso significa que ninguém vai querer pagar, a não ser por subsídio da Ancine. Só que o ritmo é muito lento. Hoje, tem grande volume de produção, distribuição garantida, mas as fontes de recurso são insuficientes para ficar equilibrado. Ou ela libera dinheiro, ou as empresas podem quebrar. Porque o setor da TV por assinatura não vai pagar esse conteúdo caro, até cinco vezes mais caro. Não tiro o mérito do objetivo de desenvolver uma indústria nacional de conteúdo, é propósito nobre e está dando certo. Mas foi aplicado no elo mais frágil da cadeia. Isso deveria ser aplicado na radiodifusão e internet. (POSSEBON, 2014, informação oral )

Quanto às fragilidades relacionadas à internet, Possebon aponta uma arquitetura tecnológica que permite um tráfego de dados superior e que está associada a novos aplicativos e serviços dos programadores de conteúdos que tornam o modelo do SeAC ultrapassado:

Uma da falhas é ser uma lei olhando para o retrovisor, criada para resolver problemas de capital estrangeiro, distribuição de conteúdo... Mas, não preparou o ambiente brasileiro para disputar com a internet. Foi feita como se fosse ambiente analógico. Em 2010, já estava claro que teria conteúdo over-thetop e o YouTube. Faltou reflexão para pensar o papel a ser cumprido nos próximos dez anos. Hoje, ela só vale para uma plataforma ultrapassada. (POSSEBON, 2014, informação oral)

Já, para Orlando Senna (2014, informação oral), o país está desenvolvendo seu próprio arranjo econômico e regulatório, porém o desequilíbrio em relação ao conteúdo estrangeiro permanece como problema principal a ser enfrentado:

O investimento do Estado na produção faz parte do modelo brasileiro. Outros países não fazem para empresas comerciais, como o Brasil e EUA. O 
Brasil faz isso e ganha uma contrapartida maravilhosa. Por exemplo, a Lei da TV por Assinatura. Dois meses depois de aprovada a perspectiva do mercado audiovisual já era $100 \%$ a mais, nos cálculos das produtoras. A Ancine é o órgão regulador que temos. Tem que buscar um equilíbrio, porque desde algum tempo está desequilibrado, com a presença das majors e canais estrangeiros. A Lei da TV por Assinatura foi jogada maravilhosa. Lógico, antes teve o FSA e etc. Mas o que a Ancine tem que chegar é uma Lei da TV Aberta. Se a Lei da TV por Assinatura vai aumentar em duzentas a trezentas vezes a produção audiovisual brasileira, como bola de neve. Se fizer com a TV aberta, o cinema e a indústria independente vão viver um mar de rosas (SENNA, 2014, informação oral)

É perceptível, nos depoimentos dos atores, que os vínculos da "Lei da TV Paga" são intensos com a televisão aberta, porém ponto primordial para continuidade da Lei 12.485 foi não avançar na regulamentação do Art. 222 da Constituição, a fim de garantir espaço para a produção brasileira independente e regional nas emissoras. Também é perceptível, em especial no depoimento de Samuel Possebon (informação oral), o crescimento da importância da internet nos fluxos do audiovisual no país, porém, também se desistiu em regular o conteúdo com o mesmo perfil ofertado no SeAC durante a tramitação.

A fragilidade normativa quanto à radiodifusão e à internet representa vínculos da rede que transbordam a Lei 12.485. Os debates em torno de Lei Geral de Comunicações Eletrônicas chegaram a ser discutidos durante a tramitação em torno da I Confecom e, posteriormente, formulados no fim do segundo mandato do governo Lula pelo então ministro da Secom-PR, Franklin Martins, mas, no primeiro governo Dilma Rousseff (2011-2014), a proposta foi engavetada.

Ainda assim, temas presentes na Lei 12.485, como a desagregação da cadeia produtiva, firmado no "Tratado de Tordesilhas", e o estímulo ao conteúdo audiovisual brasileiro, permitem conexões com uma rede midiática mais extensa. Por isso, há possibilidade de sua utilização como referência para debates futuros:

Sempre houve a tentação de utilizar o projeto pra uma lei de mídia maior. Mas nunca tomamos iniciativa para delimitar o problema, e evitar paralisar. Circunscrevemos a TV paga, mas com conceitos que mudam o paradigma. E acho perfeitamente possível fazer uma lei de meios no país que possa prosperar. A Globo vive sob pressão permanente. A democracia não comporta que as concessões sejam usadas dessa forma. É melhor negociar do que acontecer algo pela goela como o Clarín recebeu na Argentina. (BITTAR, 2014, informação oral) 
Mais incisivo quanto à relação da Lei 12.485 com uma ampla reforma regulatória é o relato de Orlando Senna (informação oral), ex-secretário do audiovisual do MinC e ex-diretorgeral da EBC durante os governos Lula. Senna traz à tona que a "Lei da TV Paga" integrou um plano de realizar uma regulação por camadas, a fim de evitar novos distúrbios políticos como os presentes durante a Ancinav:

Já que a Ancinav não foi possível, a decisão do primeiro governo foi: “Ok, não vamos dar soco em ponta de prego. Se abandona a Ancinav, se organiza a EBC, o melhor que se pode, e vamos colocar força na Ancine para passo a passo, vagarosamente, sem escândalo"... A Ancine tá fazendo isso. Faz o fundo, faz não sei o quê. Faz a lei da TV paga. Agora faz a da TV aberta. Devagar. Esse foi o plano, projeto do jogo determinado por Lula, no momento que ele viu que não faria marco geral para o audiovisual. É muito lento? É. Mas, estão sendo cumpridas as várias etapas pensadas. E digo isso porque estava no grupo. (SENNA, 2014, informação oral) 


\section{CONSIDERAÇÕES FINAIS}

No decorrer do trabalho, foi possível descrever e analisar como a configuração do audiovisual brasileiro se constitui na Rede "Lei da Tv Paga". A adoção do arcabouço teóricometodológico da Teoria do Ator-Rede (TAR) permitiu se desfazer dos mecanismos de segmentação da realidade e valorizar os rastros deixados por atores e actantes envolvidos na Rede, e assim relevas os elementos que compõem este cenário em movimento constante de transformações. Dessa forma, foram selecionadas como sujeitos e objetos de análise: leis, políticas governamentais, atas, documentos, reportagens, filmes, séries, documentários e entrevistas exclusivas. Sejam humanos, ou não-humanos, eles deixam pistas responsáveis por tecer uma rede com vínculo forte nas decisões institucionais.

Esse caminho pode ser considerado incomum na atualidade das pesquisas das Políticas de Comunicação e Cultura, e, por isso, passível de limites e fragilidades a serem desenvolvidas numa trajetória acadêmica em fase inicial, como é o caso de uma investigação de mestrado. Ainda assim, a adoção desta perspectiva teórico-metodológica permitiu continuar identificar outras duas estratégias de ordenamento que podem estimular um cenário de entraves regulatórios.

O primeiro mecanismo de segmentação a ser superado foi a metodologia de separação entre estudos destinados às políticas de comunicação e aos sobre cultura. É certo que existe um histórico na ONU que separa os direitos culturais e o direito à comunicação, bem como a reafirmação da segmentação em espaços institucionais, a exemplo de cursos universitários, leis e ministérios que distinguem comunicação e cultura. Todavia, a "Lei da TV Paga" está conectada num emaranhado regulatório, desde a arrecadação da movimentação financeira dos agentes econômicos, passando pelos meios de transporte, a redistribuição do recursos no fomento à produção, os formatos e linguagens, os processos de produção, até as negociações envolvendo os direitos autorais. Todas integram a mesma rede e precisam ser refletidas conjuntamente no espaço normativo, porque suas ações estão fortemente vinculadas.

A segunda estratégia de segmentação a ser enfrentada é a separação entre técnicas e demais processos sociais. Tradicionalmente o discurso da convergência tecnológica ou convergência de mídias fundamenta-se nessa divisão e caminha para excluir a dimensão política e 
até econômica. Não há como negar que o atual estágio tecnológico permite uma padronização na tradução das informações por meio da digitalização. Também não há como negar que as distinções estéticas conforme as plataformas se fragilizam. O conteúdo para cinema, televisão, smartfones ou computadores pessoais diminui suas distinções técnica-estéticas, porém a forma como as pessoas o acessam e, consequentemente, a maneira como se relacionam com as empresas, estão imbricadas em questões políticas e econômicas.

Por isso, o discurso da convergência tende a ser apropriado de forma conservadora como inevitabilidade técnica para viabilizar a concentração dos mercados. No SeAC, esse discurso é inerente ao conceito de serviço privado e se expande no predomínio da Sky e Net/Embratel/Claro na distribuição, com reflexos em outros serviços ofertados, inclusive o conteúdo em circulação, a exemplo da internet em banda larga e telefonia móvel e fixa.

Outro caminho chave nessa descrição foi evitar a reificação do contexto como estágio social moderno ou global. O conceito de rede permite estar aberto aos movimentos por meio de conexões históricas, e isso foi perceptível ao descrever que elementos presentes na “Lei da TV Paga" foram constituídos e transformados ao longo de décadas.

Tais opções teórico-metodológicas foram cruciais para seguir as pistas dos atores e actantes envolvidos e se desvencilhar dos mecanismos de segmentação para sistematizar e descrever a rede através dos seus mediadores. Nas considerações finais vamos analisar a constituição da Rede a partir da formação dos grupos sociais com presença nas atividades de difusão, programação e produção.

Na formação do cinema, desde a década de 1940, o Brasil é mercado estratégico para o produto hollywoodiano, em partes por fragilidade de políticas nacionais para o desenvolvimento de indústria local, mas também por uma característica do audiovisual: após retornar os custos com a produção ainda no mercado originário, a expansão em terras estrangeiras tem capacidade de lucro proporcionalmente maior. Esse elemento facilitou a Hollywood, dotado de amplo mercado interno, ser protagonista em quase todo mundo e abriu brechas para debate nos órgãos multilaterais que resultou no conceito de "Exceção Cultural" na década de 1990. A síntese desse conceito é que bens culturais podem ser acompanhados por medidas protecionistas dos estados nacionais distintas de outros bens e serviços em prol da autodeterminação dos povos.

A década de 1990 também marcou o fim da Embrafilme, enquanto caminho para valorização do cinema nacional, e, posteriormente, as políticas foram remodeladas na base da renúncia fiscal, sem planejamento voltado para distribuição, exibição e também autonomia do Estado. Isso trouxe um quadro de constante instabilidade no setor cinematográfico nacional e 
independente que intensificou suas reivindicações ao Estado de forma mais articulada, atingindo a força do produto estrangeiro e intransigência dos radiodifusores.

Nesse momento, o audiovisual nacional e independente refaz a centralidade do cinema e enfatiza seus movimentos por uma circulação transmediada, envolvendo diversas plataformas e formatos. Mesmo sem políticas satisfatórias, a digitalização nas técnicas de produção e o acúmulo de expertise estética são vínculos impulsionadores na formação desse grupo. Ele transita na tramitação da Lei da TV Paga sem o poderio econômico proporcional das teles, dos membros da ABPTA ou mesmo das Organizações Globo, mas com relativa legitimidade social e capacidade de incidência no Estado, principalmente por meio do MinC e da Ancine. Não apenas de conflitos esse trânsito, esse grupo passou a ser compreendido por grandes empresas enquanto importante numa dinâmica do mercado pautado por mudanças estéticas constantes e capacidade de captação de recursos públicos via fomento.

O crescimento deste grupo na conformação institucional também se deu na justificação do discurso de valorização da cultura nacional, nesse caso, em conformidade preponderantemente com a Globo. As medidas adotadas para reservar espaço na programação e empacotamento da TV paga para o grupo foram respaldadas em experiências internacionais e acordos multilaterais, em especial, a Convenção sobre a Proteção e Promoção da Diversidade das Expressões Culturais (2006); bem como iniciativas do Estado brasileiro como a Medida Provisória 2.228/2001 de criação da Ancine, o FSA (2006) e a EBC (2008).

O segundo grupo social destacado é formado por radiodifusores. A televisão aberta utilizou os potenciais da digitalização para manter a concentração nas grandes redes e inviabilizou a utilização do espectro para prestar outros serviços essenciais à população, ou mesmo, uma convergência com outros serviços de telecomunicações. O Sistema Brasileiro de Televisão Digital Terrestre (SBTVD-T) permite melhor integração dos canais abertos à TV por assinatura devido à valorização da alta definição cada vez mais requisitada por usuários.

Além da arquitetura tecnológica, o conteúdo da TV aberta mantém uma relação com o público ainda predominante no país. Dessa forma, o crescimento da TV por assinatura é acompanhado por apropriação dos canais e programação balizada em esportes, jornalismo e entretenimento constituído nos canais abertos. É nessa programação que está a base da pujança do conglomerado liderado pela família Marinho no SeAC. Durante a tramitação da Lei 12.485/2011, a Globo atuou de forma majoritariamente isolada em relação aos demais radiodifusores, ao aproveitar o poderio acumulado na exploração comercial do espectro, em comunhão com os interesses das elites políticas estatais. 
O ponto de partida para as negociações, o "Tratado de Tordesilhas", e sua respectiva separação entre exploração de conteúdo e infraestrutura, correspondeu majoritariamente aos anseios das Organizações Globo. E, ao mesmo tempo, não afetou negativamente os negócios das majors envolvidas com conteúdo, nem mesmo as pretensões imediatas da maioria das operadoras de telecomunicações. O "Tratado" consolidou o movimento de saída da Globo da distribuição e sua sinergia no conteúdo.

Já as cotas na programação e no empacotamento foram de encontro conceitualmente às divergências da Globo com as propostas de regulamentação do Art. 222 da Constituição Federal, bem como as duas Ancinavs abortadas. Todavia, não representa contradição a estratégia de consolidação da Globosat e da GloboFilmes, ao contrário, a valorização da produção independente, oriunda de recursos públicos, permite oxigenar a programação e distribuição. E a timidez das cotas evita a concorrência de empresas nacionais de conteúdo, em especial, as também originárias da radiodifusão.

A formação da TV por assinatura como grupo social sintetiza bem o hibridismo e a fluidez de atores e actantes envolvidos na rede. Durante cerca de 25 anos, o setor passou por transformações substantivas desde tecnologias adotadas na distribuição até a base da programação. A década de 1990 foi marcada por forte presença de grupos nacionais na distribuição, Abril e Globo, que, por sua vez, detinham uma política de disputas por exclusividade nos canais. Alguns pressupostos de serviço público chegaram a ser desenhados na Lei do Cabo no Brasil, por meio de infraestrutura única e pública, bem como canais de interesse público. Todavia, não foi isso que prevaleceu quando a Lei Geral de Telecomunicações foi acompanhada pela privatização do sistema Telebrás e o conceito de serviço privado adotado mesmo em serviços essenciais.

A reestruturação da TV por assinatura em meio à crise financeira na passagem do século foi acompanhada pela saída paulatina dos grupos nacionais e concentração na distribuição, porém um movimento de desagregação das empresas envolvidas na programação. As políticas de exclusividade continuaram com menos intensidade, mais restritas à atuação das Organizações Globo para evitar o crescimento de grupos nacionais e também para retardar a entrada de novos investimentos estrangeiros, em especial, nos canais esportivos.

Quando a tramitação da Lei 12.485/2011 foi iniciada em 2007, o serviço por assinatura já estava num período de amadurecimento, inclusive sob condições econômicas favoráveis para expansão do consumo no país. A entrada das telefônicas no cabo era caminho tratado como inevitável, frente ao contexto e ao PL 29/2007 do deputado Paulo Bornhausen (PFL/SC), que buscava, além de legitimar a situação, preparar os debates para um passo à 
frente: a possibilidade de regular o conteúdo fornecido por meio de protocolos da internet. Todavia, ele teve que dialogar com demandas estacionadas no Congresso Nacional que se referiam a problemas cabíveis à ampla reforma regulatória nas comunicações eletrônicas condizente com o cenário do fim do século XX.

A solução posta com o "Tratado de Tordesilhas" retirou a possibilidades das teles atuarem diretamente na programação e na produção de conteúdo e, por isso, passou-se a privilegiar na rede audiovisual o movimento das majors estrangeiras, basicamente estadunidenses, na formação do grupo da TV por assinatura. A partir da década de 1990, este serviço fechado passou a ser espaço privilegiado para Hollywood perpetuar sua pujança no conteúdo audiovisual no Brasil. As fragilidades regulatórias facilitaram a presença estrangeira na TV paga, todavia um ambiente com tal multiplicidade de oferta à produção brasileira não tinha lastro para preencher com grau satisfatório de competitividade a programação.

Essa questão não é meramente quantitativa, o conhecimento desenvolvido nas diversas etapas da circulação nos EUA permite apuração no roteiro, direção, interpretação, efeitos especiais, estratégias de marketing, animação, distribuição, efeitos especiais entre outros. Os produtos que mais desenvolveram essa expertise são as obras de ficção. Na TV por assinatura, além da presença significativa dos longas-metragens, as obras seriadas têm permitido uma relação forte com o público, e, por vezes, com custos inferiores. Mais ainda, elas têm maior capacidade de se adaptar às plataformas móveis e aos modelos de programação horizontais e, ou, verticais, ou mesmo, sob demanda.

Vale mencionar que o desenvolvimento dessa expertise também é um fato que distancia a atuação das teles diretamente. Lidar com infraestrutura e conteúdo requer culturais profissionais bem distintas. Uma dessas especificidades é relação dos direitos autorais nas obras. A Lei da Tv Paga se depara com essa questão desde "Tratado de Tordesilhas", e avança na demarcação da produção e programação brasileira e independente a fim de serem contempladas com mecanismos de estímulo e reserva. Já a inovação do poder dirigente, faltam elementos para avaliar com maior clareza sua eficácia.

A decisão na Lei 12.485/2011 de especificar como espaço qualificado os canais que privilegiam um perfil de conteúdo com a circulação mais dinâmica abriu caminhos para potencializar as políticas de cotas na programação e no empacotamento. Nesse sentido, também não pode ser desprezada a expertise nacional com décadas de cinematografia, novelas, minisséries e séries para ocupar esses espaços.

Até se tornar uma peça de marketing político do governo federal, a exemplo do lançamento do Programa Brasil de Todas as Telas, o audiovisual brasileiro se desprendeu consi- 
deravelmente da imagem de incapacidade nata frente a concorrência internacional, e também suplantou a incapacidade de legitimar-se no seio do Estado. Paulatinamente, vai flertando mais com a antípoda: uma euforia de grandiosidade conhecida nos prêmios do Cinema Novo e também na internacionalização das novelas da Rede Globo.

Os dados sistematizados em torno dos primeiros anos da "Lei da TV Paga" demonstram um objetivo salto no audiovisual brasileiro, todavia, ainda existem gargalos significativos a serem enfrentados. Nesse sentido, o Estado é um mediador a ser realçado na constituição dessa rede.

A Ancine destaca-se no cenário da Lei ao assumir as responsabilidades de qualificar os mecanismos de fomento, cumprimento das cotas, relações de direitos autorais e fiscalizar a atuação dos agentes de mercado. Seu poderio é gradativo nas políticas do audiovisual, e acompanhado por sobreposição de funções. Ela mesmo fiscaliza suas ações, em especial as destinadas ao fomento, pois não um acompanhamento incisivo do frágil Conselho Superior de Cinema - órgão criado junto com a Ancine para definir e aprovar as políticas do audiovisual.

No caso do fomento, que, por meio do Fundo Setorial do Audiovisual (FSA), empodera a Ancine na relação com a produção independente, é perceptível a dificuldade para alocar os recursos arrecadados. Obviamente, isso pode ser atenuado com aumento no funcionalismo, e, ainda assim, é necessário acomodar o dinheiro de público de forma responsável. Entretanto, a dificuldade no fomento representa a constituição de uma rede que preza por interesses privados e privilegia o modelo de grandes grupos empresariais e as repassa para a produção independente e até para o público, tratado meramente como consumidor.

$\mathrm{Na}$ "Lei da TV Paga" esse modelo é inerente a um processo de exclusão. Durante as entrevistas e coleta de materiais, o modelo de serviço público não se apresentou como preocupação. Também não foi preocupação associar a atuação da Ancine a diretrizes mais aprofundadas das políticas culturais em relação a grupos historicamente discriminados, sob uma concepção mais ampla de diversidade e direitos humanos. Tais silêncios se revestem na ausência de concepção de política pública no Fundo Setorial do Audiovisual (FSA) e nas cotas da programação.

Por isso, faz-se necessário refletir sobre a contribuição da Lei 12.485/2011 nos debates por novas reformas regulatórias nas políticas comunicações e cultura. Quatro pontos podem ser destacados na Lei para futuros debates. O primeiro deles é uma visão mais holística do audiovisual ao relacionar diversas plataformas e mecanismos de produção como passíveis de reconhecimento pelos instrumentos normativos. O segundo é o aperfeiçoamento quanto aos perfis do conteúdo, em especial ao adotar o conceito de espaço qualificado na programa- 
ção. O terceiro são os mecanismos novos ou aprofundados para estimular e proteger o conteúdo audiovisual brasileiro, independente e regional. Por fim, o quarto é determinar limites à concentração na cadeia produtiva.

Os quatro detém diretrizes importantes para regulamentar a televisão aberta com base no Capítulo V da Constituição Federal, desenvolver nova Lei de Direitos Autorais, rediscutir as leis Rouanet e do Audiovisual e, até mesmo, avançar sobre a internet na regulamentação do seu Marco Civil. A questão é que tais diretrizes foram acompanhadas por fortalecimento de uma rede ainda composta e mediada, majoritariamente, por princípios privados, que, por sua vez, são conectados historicamente à cultura do silêncio no país. 


\section{REFERÊNCIAS BIBLIOGRÁFICAS}

ALVAREZ, Vera Cíntia. R. Inter. Interdisc. INTERthesis, Florianópolis, v. 6, n. 1, jan./jul. p. 254-278, 2009.

AMORIM, Antonio C. Bellini. Rede Record 45 anos de história. São Paulo: Antonio Bellini Editora e Design, 1999.

ANTONIK, Luis Roberto. Entrevista IV [ago. 2014]. Entrevistador: Pedro Andrade Caribé. Brasília, 2014. 1 arquivo .mp4 (58 min)

BAHIA, Lia. Discursos, políticas e ações: processos de industrialização do campo cinematográfico brasileiro. São Paulo: Itaú Cultural: Iluminuras, 2012.

BARBOSA, Marialva. In RIBEIRO, Ana Paula Goulart; SACRAMENTO, Igor; ROXO, Marco (orgs.). A história da TV no Brasil: do início aos dias de hoje. São Paulo: Contexto, 2010

BECKER, Beatriz. O sucesso da telenovela "pantanal" e as novas formas de ficção televisiva. in RIBEIRO, Ana Paula Goulart; SACRAMENTO, Igor; ROXO, Marco (orgs.). A história da TV no brasil: do início aos dias de hoje. São Paulo: Contexto, 2010

BERGAMO, Mônica. Folha de São Paulo, domingo, 15 de fevereiro de 2004.

BHAMBRA, Gurminder. Retthinking Modernity: postcolonialism and the sociological imagination. New York: Palgrave Macmillan, 2007.

BITTAR, Jorge. Entrevista VII . [nov. 2014]. Entrevistador: Pedro Andrade Caribé. Brasília, 2014. 1 arquivo .mp4 (60 min.).

BOCCATO, Paulo. Tela Viva. Ed. 98, p. 12-14, 2000

BOLAÑO, César Ricardo Siqueira (Orgs.). Rede Globo: 40 anos e poder e hegemonia. São Paulo: Paulus. 2005.

BOLAÑO, César Ricardo Siqueira. Mercado Brasileiro de Televisão. $2^{\mathrm{a}}$ ed. rev. e ampl. São Cristóvão, SE: UFS; São Paulo: EDUC, 2004

BOLTANSKI, Luc. Criticism and the expansion of knowledge. European Journal of Social Theory, v. n. p. 2011. Entrevista concedida a Mauro Basaure.

BOLTANSKI, Luc. El Amor y la justicia como competencias: tres ensayos de sociología de la acción. Buenos Aires: Amorrortu, 2000.

BRANCO, Sergio. O domínio público no direito autoral brasileiro. Rio de Janeiro: Lumen Juris, 2011.

BRANDÃO, Cristina. As primeiras produções televisivas. In RIBEIRO, Ana Paula Goulart; 
SACRAMENTO, Igor; ROXO, Marco (Orgs.). A história da TV no Brasil: do início aos dias de hoje. São Paulo: Contexto, 2010

BRASIL. Agência Nacional de Cinema. Informe de Acompanhamento de Mercado. Tv Paga: monitoramento de programação, 2013. Ancine/SAM. Disponível em:< http://oca.ancine.gov.br/media/SAM/2013/Programacao/InformeTVPaga2013.pdf > Acesso em: 28 jan. 2015.

Informe, suplementação de recursos do Fundo Setorial do Audiovisual. Disponível em: $<\quad$ http://www.ancine.gov.br/sala-imprensa/noticias/fundo-setorial-do-audiovisualinveste-r-50-milh-es-em-suplementa-o-de-recur-0 >. Acesso em: 28 jan. 2015.

Classificação dos canais de programação. Disponível em: $<$ http://www.ancine.gov.br/sites/default/files/classificacao-canais-programacao/listaclassificacao-canais-08012015.pdf> . Acesso em: 28 jan. 2015.

BRASIL. Fundo Setorial do Audiovisual Investimentos Disponibilizados Para as Linhas de Ação de Produção e Distribuição. Atualizado no dia 8 jan. 2015. Disponível em : $<$ http://fsa.ancine.gov.br/resultados/investimentos/investimentos-linhas-acao $>$. Acesso em: 28 jan. 2015.

Ações orçamentárias. Disponível em: < http://fsa.ancine.gov.br/o-que-e-fsa/acoesorcamentarias $>$. Acesso em: 15 jan. 2015.

Relatório anual de gestão_2013. Disponível em: < http://fsa.ancine.gov.br/sites/default/files/relatorios-de-gestao/Relat $\% \mathrm{C} 3 \% \mathrm{~B} 3 \mathrm{rio} \% 20 \mathrm{de}$ \%20Gest $\%$ C3\%A3o\%20FSA\%202013\%20-\%20\%C3\%BAltima\%20vers \%C3\%A3o.pdf Último acesso 28 jan. 2015.

BRASIL. Congresso. Câmara dos Deputados. Relatório de Eduardo Cunha (PMDB/RJ). Disponível em: $<$ http://imagem.camara.gov.br/Imagem/d/pdf/DCD15MAI2010.pdf\#page=273 $>$. Acesso em: 28 jan. 2015.

Relatório de Henrique Lustosa (PMDB/CE). Disponível em: http://imagem.camara.gov.br/Imagem/d/pdf/DCD17DEZ2009.pdf\#page=412 Último acesso, 25 jan. 2015.

. Votação do PLC 116/2010, dia 16 de agosto de 2011. Disponível em: $<$ http://www.senado.gov.br/atividade/materia/mate/votacao.asp?ct=1838710 >. Acesso em: 28 jan. 2015.

Requerimento, Paulo Renato Souza (PSDB/SP). Disponível em: $<$ http://www.camara.gov.br/proposicoesWeb/prop_mostrarintegra;jsessionid=0646C288 7038425528B79FF045DF4956.proposicoesWeb1? codteor $=584402 \&$ filename $=$ Tramitacao-PL+29/2007>. Acesso em: 25 jan. 2015.

BRASIL. Presidência da República. Decreto 5.820, de 29 de junho de 2006. Dispõe sobre a implantação do SBTVD-T, estabelece diretrizes para a transição do sistema de transmissão analógica para o sistema de transmissão digital do serviço de radiodifusão de sons e imagens e do serviço de retransmissão de televisão, e dá outras providências. 
. Decreto 6.177 , de $1^{\circ}$ de agosto de 2007. Promulga a Convenção sobre a Proteção e Promoção da Diversidade das Expressões Culturais, assinada em Paris, em 20 de outubro de 2005.

Lei 11.437 , de 28 de dezembro de 2006, Altera a destinação de receitas decorrentes da Contribuição para o Desenvolvimento da Indústria Cinematográfica Nacional -CONDECINE, criada pela Medida Provisória no 2.228-1, de 6 de setembro de 2001, visando ao financiamento de programas e projetos voltados para o desenvolvimento das atividades audiovisuais; altera a Medida Provisória no 2.228-1, de 6 de setembro de 2001, e a Lei no 8.685, de 20 de julho de 1993, prorrogando e instituindo mecanismos de fomento à atividade audiovisual; e dá outras providências

Lei 11.652 , de 7 de abrilde 2008. Institui os princípios e objetivos dos serviços de radiodifusão pública explorados pelo Poder Executivo ou outorgados a entidades de sua administração indireta; autoriza o Poder Executivo a constituir a Empresa Brasil de Comunicação - EBC; altera a Lei no 5.070, de 7 de julho de 1966; e dá outras providências.

Lei 12.485 de 12 de setembro de 2011. Dispõe sobre a comunicação audiovisual de acesso condicionado; altera a Medida Provisória no 2.228-1, de 6 de setembro de 2001, e as Leis nos 11.437, de 28 de dezembro de 2006, 5.070, de 7 de julho de 1966, 8.977, de 6 de janeiro de 1995, e 9.472, de 16 de julho de 1997; e dá outras providências.

. Lei 4.117, de 27 de agosto de 1962. Institui o Código Brasileiro de Telecomunicações.

Lei 8.685 , de 20 de julho de 1993 . Cria mecanismos de fomento à atividade audiovisual e dá outras providências.

BRASIL. Presidência da República. Lei 8.977, de 6 de janeiro de 1995. Dispõe sobre o Serviço de TV a Cabo e dá outras providências.

Lei 9.472, de 16 de julho de 1997. Dispõe sobre a organização dos serviços de telecomunicações, a criação e funcionamento de um órgão regulador e outros aspectos institucionais, nos termos da Emenda Constitucional nº 8, de 1995.

Medida Provisória 2.228-1, de 6 de setembro de 2001. Estabelece princípios gerais da Política Nacional do Cinema, cria o Conselho Superior do Cinema e a Agência Nacional do Cinema - ANCINE, institui o Programa de Apoio ao Desenvolvimento do Cinema Nacional - PRODECINE, autoriza a criação de Fundos de Financiamento da Indústria Cinematográfica Nacional - FUNCINES, altera a legislação sobre a Contribuição para o Desenvolvimento da Indústria Cinematográfica Nacional e dá outras providências.

BRASIL. Secretaria de Assuntos Estratégicos da Presidência da República. Produção de conteúdo nacional para mídias digitais. Brasília, 2011.

BRIGGS, Asa; BURKE; Peter. Uma história social da mídia: de Gutenberg à internet. 2. ed. rev. e ampl. Rio de Janeiro: ZAHAR; 2006.

BRISSAC, Chantal. Istoé Gente. 13 out. 1999. Disponível em: $<$ http://www.terra.com.br/istoegente/10/reportagens/rep_anamaria.htm >. Acesso em: 10 jan. 2015. 
BRITTOS, Valério Cruz; BOLAÑO, César Ricardo Siqueira (orgs.). Rede Globo: 40 anos de poder e hegemonia. São Paulo: Paulus. 2005.

BRITTOS, Valério Cruz; BOLAÑO, César Ricardo Siqueira. A televisão brasileira na era digital: exclusão, esfera pública e movimentos estruturantes. São Paulo: Paulus, 2007.

BUENO, Clodoaldo; CERVO, Amado Luiz. História da Política Exterior do Brasil. 4 ed. Rev. Ampl. Brasília: Editoria Universidade de Brasília, 2011

CALLON, Michel. A coperformação das ciências e da sociedade. Revista Política e Sociedade, n. 14, abr. 2009. Entrevista concedida a Marcos Antônio Mattedi, Marcia Grisotti, Maiko Rafael Spiess e Rafael Bennertz.

CALLON, Michel. Dos estudos de laboratório aos estudos de coletivos heterogêneos, passando pelos gerenciamentos econômicos. Sociologias, Porto Alegre, ano 10, n. 19, p. 302-321, jan./jun. 2008. Entrevista concedida a Antonio Arellano Hernández e Ivan da Costa Marques.

CALLON, Michel. Why virtualism paves the way to policital impotence. Economic Sociology. European Electronic Newsletter, v. 6, n. 2, Fev. 2005.

CARRATO, Ângela. Uma história da TV pública brasileira. 2013. 286 f. Tese (Doutorado) Universidade de Brasília, Faculdade de Comunicação, Programa de Pós-Graduação em Comunicação, Brasília, 2013.

CASTRO, Cossete. Globo e Educação: um casamento que deu certo. In BRITTOS, Valério Cruz; BOLAÑO, César Ricardo Siqueira (orgs.). Rede Globo: 40 anos de poder e hegemonia. São Paulo: Paulus. 2005.

CONNELL, Ranewyn. Southern Theory: the global dynamic of knowledge in social sciences. Cambridge: Polity, 2007.

COUTINHO, Carlos Nelson. Cultura e Sociedade no Brasil: ensaios sobre ideias e formas, Oficina de Livros. [S. 1.: s. n., s. d.].

DANTAS, Marcos. Convergência digital: entre os "jardins murados" e as praças públicas. In Políticas de comunicación en el capitalismo contemporaneo.1 ed. Buenos Aires: CLACSO, 2010.

, Marcos. Entrevista II. [ago.2014]. Entrevistador: Pedro Andrade Caribé. Videoconferência. 2 arquivos .mp4 (53 min)

, Marcos. O espetáculo do crescimento: A indústria cultural como novo motor de desenvolvimento na atual fase do capitalismo mundial. In Produção de Conteúdo para mídias digitais. Brasília: Secretaria de Assuntos Estratégicos, 2011.

DIEGUES, Cacá. Tabu, Rio de Janeiro, n. 41, ano IV, set. 1989.

DUARTE, Luiz Guilherme. Pecado Capital: A novela dos Marinho com a TV paga. In BRITTOS, Valério Cruz.

FALCAO, Angela; ALMEIDA, Candido José Mendes de; MACEDO, Claudia. TV ao vivo: 
Depoimentos. São Paulo: Brasiliense, 1988.

FANON, Frantz. Pele Negra, Máscaras Brancas. Salvador: EDUFBA, 2008.

FECHINE, Yvana; FIGUERÔA, Alexandre. Cinema e televisão no contexto da transmediação. IN RIBEIRO, Ana Paula Goulart; SACRAMENTO, Igor; ROXO, Marco (orgs.). A história da TV no Brasil: do início aos dias de hoje. São Paulo: Contexto, 2010.

FERNANDES, Daniela Pfeiffer. Diversidade cultural e concentração da indústria audiovisual no eixo Rio - São Paulo: Análise do contexto e implicações para desenvolvimento cultural brasileiro. Dissertação apresentada ao Programa de PósGraduação em Comunicação Social da PUC-Rio, 2010

FERREIRA, Giovandro Marcus; SAMPAIO, Adriano de Oliveira; MAGALHÃES, Daniella Rocha; CARIBÉ, Pedro Andrade. A Construção da violência na televisão da Bahia: um estudos dos programas Se Liga Bocão e Na Mira. Salvador: EDUFBA, 2011.

GARCIA, Mauro. Entrevista III. [ago.2014]. Entrevistador: Pedro Andrade Caribé. Videoconferência, 2014. 1 arquivo .mp4 (70 min)

GIL, Antonio Carlos. Metódos e técnicas de pesquisa Social. São Paulo: Atlas, 2010.

GOLDING, Peter; MURDOCK, Graham. Culture, Communications, ande Political Economy. In Curran, James e Gurevitch, Michael (orgs.). Mass media and society. Tottenham, United Kingdom, 1991.

GOMIDE, Carla. Produção audiovisual independente e televisão: a luta pelo espaço de exibição. Dissertação (Mestrado) - Universidade de Brasília, Faculdade de Comunicação, Programa de Pós-Graduação em Comunicação, Brasília, 2011.

HABERMAS, Jurgen. O Discurso filosófico da modernidade. Martins Fontes, São Paulo, 2000 .

HAMBURGER, Esther. O Brasil antenado: a sociedade da novela. Rio de Janeiro: Jorge Zahar, 2005.

HERZ, Daniel. A História secreta da rede globo. São Paulo: Ortiz, 2009.

IKEDA, Marcelo. O modelo das leis de incentivo fiscal e as políticas públicas cinematográficas a partir da década de noventa. Dissertação apresentada ao Programa de Pós-Graduação em Comunicação da Universidade Federal Fluminense, 2011.

JAMBEIRO, Othon. A TV no Brasil do século XX. Salvador: EDUFBA, 2011.

JENKINS, Henry. Cultura da convergência. Tradução de Susana Alexandria. São Paulo: Aleph, 2012.

JUSTINO, Mário. Nos bastidores do reino: a vida secreta da Igreja Universal do Reino de Deus. Geração Editorial,1995 .

KAUARK, Giuliana. Oportuna diversidade: A participação do Ministério da Cultura do Brasil 
durante a negociação da Convenção sobre a Proteção e a Promoção da Diversidade das Expressões Culturais. Dissertação (Mestrado) - Universidade Federal da Bahia, Faculdade de Comunicação, Programa de Pós-Graduação em Comunicação, Salvador, 2009.

KEHL, Maria Rita. Eu vi um Brasil na Tv. In Um país no ar: história da TV brasileira em três canais. SIMỖES, Inaiá; COSTA, Henrique; KEHL, Maria Rita. Editora Brasiliense. São Paulo, 1986

LATOUR, Bruno. Ciência em ação: como seguir cientistas e engenheiros sociedade afora. São Paulo: Editora UNESP, 2000

LATOUR, Bruno. Jamais fomos modernos: ensaio de antropologia simétrica. Rio de Janeiro: Ed. 34, 1994.

LATOUR, Bruno. Reagregando o social: uma introdução à teoria do ator-rede. Salvador, EDUFBA, 2012.

LAW, John. After method: mess in social science research . London: Routledge, 2004.

LESSIG, Lawrence. Como a grande mídia usa a tecnologia e a lei para bloquear a cultura e controlar a criatividade. São Paulo: Trama, 2005

LIMA, Venicio Artur de. Comunicação e cultura: as idéias de Paulo Freire. Rio de janeiro: Paz e Terra, 1981.

Venício Artur de. Mídia: teoria e política. São Paulo: Fundação Perseu Abramo, 2 ed, 2004.

Venício Artur de. Regulação das Comunicações: história, poder e direitos. São Paulo: Paulus, 2011.

Venício Artur de. A censura disfarçada. In. LIMA, Venício; GUIMARÃES, Juarez. Liberdade de Expressão: as várias faces de um desafio (orgs.) São Paulo: Paulus, 2013.

, Venício Artur; CAPARELLI, Sérgio. Comunicação e televisão: desafios da pósglobalização. São Paulo: Hacker, 2004.

LOBATO, Elvira. "Globo perde o controle da TV paga Sky”. Folha de São Paulo. 1 ago. 2002. Disponível em: http://www.observatoriodaimprensa.com.br/artigos/asp070820024.htm >. Acesso em: 7 jan. 2015.

MARSON, Melina Izar. O Cinema da Retomada: Estado e cinema no Brasil da dissolução da Embrafilme à criação da Ancine. Campinas, SP: [s.n.], 2006.

MATTELART, Arman e Michèle. História das teorias da comunicação. São Paulo: Loyola, 2006.

MATTOS, Sergio. A televisão no Brasil: 50 anos de história (1950-2000). Salvador: Ianama, 2000 
MELO, José Marques de. Teorias da comunicação: paradigmas latino-americanos. Petrópolis: Vozes, 1998.

MIRA, Maria Celeste Mira. O Moderno e o popular na TV de Silvio Santos. In RIBEIRO, Ana Paula Goulart; SACRAMENTO, Igor; ROXO, Marco (orgs.). A história da TV no Brasil: do início aos dias de hoje. São Paulo: Contexto, 2010.

MIZUKAMI, Pedro Nicoletti; VALENTE, Mariana Giogertii. Copyright Week: O que aconteceu com a reforma do direito autoral no Brasil? Disponível em: $<\mathrm{http}$ ://www.creativecommons.org.br/blog/copyright-week-pt/>. Acesso em: 28 jan. 2015.

MOSCO, Vincent. The Political Economy of Communication. Londres: Sage Publications, 1996.

MOTA, Regina. O programa "Abertura" e a épica de Glauber Rocha. In RIBEIRO, Ana Paula Goulart; SACRAMENTO, Igor; ROXO, Marco (orgs.). A história da TV no Brasil: do início aos dias de hoje. São Paulo: Contexto, 2010

MURTINHO, Rodrigo. O mercado de TV por assinatura no Brasil: crise e reestruturação diante da convergência tecnológica. Dissertação apresentada ao Curso de Mestrado em Comunicação da Universidade Federal Fluminense, 2005

MUNIZ, Ricardo. Revista Exame. Disponível em: http://exame.abril.com.br/negocios/noticias/m0076245/ >. Acesso em: 7 jan. 2015.

ORTIZ RAMOS, J. M. Cinema, estado e lutas culturais: anos 50, 60, 70. Rio de Janeiro: Paz e Terra, 1983.

ORTIZ, Renato; RAMOS, José Mário Ortiz; BORELLI, Silvia Helena Simões. Telenovela: história e produção. 2 ed. São Paulo: Brasiliense, 1991.

ORTIZ, Renato. A Escola de Frankfurt e a Questão da Cultura de Massa. Revista Brasileira de Ciências Sociais, v. , n. , p. -, ano.

PAES, José de Souza Filho (Tito); NAZARENO, Claudio. Entrevista VI. [set.2014]. Entrevistador: Pedro Andrade Caribé. Brasília, 1 arquivo .mp4 (49 min)

PATÊZ, Alexander. Entrevista IX. [dez.2014] Entrevistador: Pedro Andrade Caribé. Rio de Janeiro, 2014. 1 arquivo .mp4 (72 min)

POOL, Ithiel de Sola. Technologies of freedom. Cambridge: Belknap, 1983.

POSSEBON __. [Sem título]. Tela Viva. Ed. 170, ano 16, p. 20-23, abr. 2007.

POSSEBON ___ [Sem título]. Teletime. Ed. 138, ano 13, p. 8-13, nov. 2007.

POSSEBON, Samuel. Entrevista I. [jul.2014]. Entrevistador: Pedro Andrade Caribé. Brasília, 2014. 2 arquivos .mp4 (65 $\mathrm{min})$

POSSEBON, Samuel. Guerra anunciada. Tela Viva. Ed. 164, ano 15, p 22-23, set. 2006. 
POSSEBON, Samuel. TV Por Assinatura: 20 anos de evolução. São Paulo: Save Produção, 2009.

RAMOS, Jose Mario Ortiz. Televisao, publicidade e cultura de massa. Petropolis: Editora Vozes Ltda, 1995.

RAMOS, Murilo. Às margens da estrada do futuro - comunicações, políticas e tecnologias. Livro-eletrônico. Disponível em: <www.unb.br/fac/publicacoes/murilo $>$. Brasília: Universidade de Brasília, 2000.

RIBEIRO, Ana Paula Goulart; SACRAMENTO, Igor; ROXO, Marco (orgs.). A história da TV no Brasil: do início aos dias de hoje. São Paulo: Contexto, 2010

ROCHA, G. Revisão crítica do cinema brasileiro. São Paulo: Cosac \& Naïf, 2003.

ROCHA, Renata. Políticas Culturais e Televisão Pública. O Processo de Conformação da Empresa Brasil de Comunicação/Tv Brasil. Tese apresentada ao Programa Multidisciplinar de Pós-Graduação em Cultura e Sociedade do Instituto de Humanidades, Artes e Ciências da UFBA, 2014

RUBIM, A. Albino C. As políticas culturais e o governo Lula. Fundação Perseu Abramo, São Paulo, 2011.

SANTOS, Milton. Por uma outra globalização: do pensamento único à consciência universal. Rio de Janeiro: Record, 2002.

SANTOS, Suzy dos. Uma Convergência Divergente: a centralidade da TV aberta no setor audiovisual brasileiro. Salvador: 2004.

SCHILLER, Herbert. Information and the crisis economy. New York;Oxford University Press, 1986

SENNA, Orlando. Entrevista VIII. [nov.2014]. Entrevistador: Pedro Andrade Caribé. Rio de Janeiro, 2 arquivos .mp4 (132 min)

SENNA, Orlando. O homem da montanha: biografia produzida por Hermes Leal. São Paulo: Imprensa Oficial, 2008.

SIMIS, Anita. Estado e cinema no Brasil. 2. ed. São Paulo: Annablume, 2008. 313p.

SIMIS, Anita. Situacón del audiovisual brasileño en lá década de los noventa. 1998

SIMÕES, Inimá F. País no ar: Historia da TV brasileira em tres canais(um). Sao paulo: Brasiliense, 1986.

TAVORALO, Douglas. O bispo: a história revelada de Edir Macedo. São Paulo: Larousse, 2007.

TRAUTMAN, Tereza. Entrevista X. [jan.2015] Entrevistador: Pedro Andrade Caribé. Videoconferência, 2015. 1 arquivo .mp4 (82min).

UNESCO - Comissão Internacional para o Estudo dos Problemas da Comunicação. Um 
mundo e muitas vozes: comunicação e informação na nossa época. Rio de Janeiro: Ed. Fundação Getúlio Vargas, 1983.

WU, Tim. Império da Comunicação: do telefone à internet, da AT\&T ao Google. Rio de Janeiro: Zahar, 2012.

XAVIER, Ismail. O cinema brasileiro moderno. 2. ed. São Paulo: Paz e Terra, 2004. 


\title{
ANEXO - Lei. 12.485/2011
}

\author{
Presidência da República \\ Casa Civil \\ Subchefia para Assuntos Jurídicos
}

LEI No 12.485, DE 12 DE SETEMBRO DE 2011.

Dispõe sobre a comunicação audiovisual de acesso

Mensagem de veto

Vigência

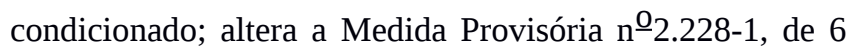
de setembro de 2001, e as Leis $\mathrm{n} \underline{\mathrm{OS}} 11.437$, de 28 de dezembro de 2006, 5.070, de 7 de julho de 1966, 8.977, de 6 de janeiro de 1995, e 9.472, de 16 de julho de 1997; e dá outras providências.

A PRESIDENTA DA REPÚBLICA Faço saber que o Congresso Nacional decreta e eu sanciono a seguinte Lei:

\section{CAPÍTULO I}

\section{DO OBJETO E DAS DEFINIÇÕES}

Art. $1^{\underline{0}}$ Esta Lei dispõe sobre a comunicação audiovisual de acesso condicionado.

Parágrafo único. Excluem-se do campo de aplicação desta Lei os serviços de radiodifusão sonora e de sons e imagens, ressalvados os dispositivos previstos nesta Lei que expressamente façam menção a esses serviços ou a suas prestadoras.

Art. $2^{\underline{0}}$ Para os efeitos desta Lei, considera-se:

I - Assinante: contratante do serviço de acesso condicionado;

II - Canal de Espaço Qualificado: canal de programação que, no horário nobre, veicule majoritariamente conteúdos audiovisuais que constituam espaço qualificado;

III - Canal Brasileiro de Espaço Qualificado: canal de espaço qualificado que cumpra os seguintes requisitos, cumulativamente:

a) ser programado por programadora brasileira;

b) veicular majoritariamente, no horário nobre, conteúdos audiovisuais brasileiros que constituam espaço qualificado, sendo metade desses conteúdos produzidos por produtora brasileira independente;

c) não ser objeto de acordo de exclusividade que impeça sua programadora de comercializar, para qualquer empacotadora interessada, os direitos de sua exibição ou veiculação;

IV - Canal de Programação: resultado da atividade de programação que consiste no arranjo de conteúdos audiovisuais organizados em sequência linear temporal com horários predeterminados;

V - Coligada: pessoa natural ou jurídica que detiver, direta ou indiretamente, pelo menos 20\% (vinte por cento) de participação no capital votante de outra pessoa ou se o capital votante de ambas for detido, direta ou indiretamente, em pelo menos 20\% (vinte por cento) por uma mesma pessoa natural ou jurídica, nos termos da regulamentação editada pela Agência Nacional de Telecomunicações - Anatel;

VI - Comunicação Audiovisual de Acesso Condicionado: complexo de atividades que permite a emissão, transmissão e recepção, por meios eletrônicos quaisquer, de imagens, acompanhadas ou não de sons, que resulta na entrega de conteúdo audiovisual exclusivamente a assinantes;

VII - Conteúdo Audiovisual: resultado da atividade de produção que consiste na fixação ou transmissão de imagens, acompanhadas ou não de som, que tenha a finalidade de criar a impressão de movimento, independentemente dos processos de captação, do suporte utilizado inicial ou posteriormente para fixá-las ou 
transmiti-las, ou dos meios utilizados para sua veiculação, reprodução, transmissão ou difusão;

VIII - Conteúdo Brasileiro: conteúdo audiovisual produzido em conformidade com os critérios estabelecidos no inciso V do art. $1^{\underline{0}}$ da Medida Provisória nํㅡ 2.228-1, de 6 de setembro de 2001;

IX - Conteúdo Jornalístico: telejornais, debates, entrevistas, reportagens e outros programas que visem a noticiar ou a comentar eventos;

X - Distribuição: atividades de entrega, transmissão, veiculação, difusão ou provimento de pacotes ou conteúdos audiovisuais a assinantes por intermédio de meios eletrônicos quaisquer, próprios ou de terceiros, cabendo ao distribuidor a responsabilidade final pelas atividades complementares de comercialização, atendimento ao assinante, faturamento, cobrança, instalação e manutenção de dispositivos, entre outras;

XI - Empacotamento: atividade de organização, em última instância, de canais de programação, inclusive nas modalidades avulsa de programação e avulsa de conteúdo programado, a serem distribuídos para o assinante;

XII - Espaço Qualificado: espaço total do canal de programação, excluindo-se conteúdos religiosos ou políticos, manifestações e eventos esportivos, concursos, publicidade, televendas, infomerciais, jogos eletrônicos, propaganda política obrigatória, conteúdo audiovisual veiculado em horário eleitoral gratuito, conteúdos jornalísticos e programas de auditório ancorados por apresentador;

XIII - Eventos de Interesse Nacional: acontecimentos públicos de natureza cultural, artística, esportiva, religiosa ou política que despertem significativo interesse da população brasileira, notadamente aqueles em que participem, de forma preponderante, brasileiros, equipes brasileiras ou seleções brasileiras;

XIV - Modalidade Avulsa de Conteúdo Programado ou Modalidade de Vídeo por Demanda Programado: modalidade de conteúdos audiovisuais organizados em canais de programação e em horário previamente definido pela programadora para aquisição avulsa por parte do assinante;

XV - Modalidade Avulsa de Programação, ou Modalidade de Canais de Venda Avulsa: modalidade de canais de programação organizados para aquisição avulsa por parte do assinante;

XVI - Pacote: agrupamento de canais de programação ofertados pelas empacotadoras às distribuidoras, e por estas aos assinantes, excluídos os canais de distribuição obrigatória de que trata o art. 32;

XVII - Produção: atividade de elaboração, composição, constituição ou criação de conteúdos audiovisuais em qualquer meio de suporte;

XVIII - Produtora Brasileira: empresa que produza conteúdo audiovisual que atenda as seguintes condições, cumulativamente:

a) ser constituída sob as leis brasileiras;

b) ter sede e administração no País;

c) $70 \%$ (setenta por cento) do capital total e votante devem ser de titularidade, direta ou indireta, de brasileiros natos ou naturalizados há mais de 10 (dez) anos;

d) a gestão das atividades da empresa e a responsabilidade editorial sobre os conteúdos produzidos devem ser privativas de brasileiros natos ou naturalizados há mais de 10 (dez) anos;

XIX - Produtora Brasileira Independente: produtora brasileira que atenda os seguintes requisitos, cumulativamente:

a) não ser controladora, controlada ou coligada a programadoras, empacotadoras, distribuidoras ou concessionárias de serviço de radiodifusão de sons e imagens;

b) não estar vinculada a instrumento que, direta ou indiretamente, confira ou objetive conferir a sócios minoritários, quando estes forem programadoras, empacotadoras, distribuidoras ou concessionárias de serviços de radiodifusão de sons e imagens, direito de veto comercial ou qualquer tipo de interferência comercial sobre os conteúdos produzidos;

c) não manter vínculo de exclusividade que a impeça de produzir ou comercializar para terceiros os conteúdos audiovisuais por ela produzidos; 
XX - Programação: atividade de seleção, organização ou formatação de conteúdos audiovisuais apresentados na forma de canais de programação, inclusive nas modalidades avulsa de programação e avulsa de conteúdo programado;

XXI - Programadora Brasileira: empresa programadora que execute suas atividades de programação no território brasileiro e que atenda, cumulativamente, as condições previstas nas alíneas “a” a “c” do inciso XVIII deste artigo e cuja gestão, responsabilidade editorial e seleção dos conteúdos do canal de programação sejam privativas de brasileiros natos ou naturalizados há mais de 10 (dez) anos;

XXII - Programadora Brasileira Independente: programadora brasileira que atenda os seguintes requisitos, cumulativamente:

a) não ser controladora, controlada ou coligada a empacotadora ou distribuidora;

b) não manter vínculo de exclusividade que a impeça de comercializar, para qualquer empacotadora, os direitos de exibição ou veiculação associados aos seus canais de programação;

XXIII - Serviço de Acesso Condicionado: serviço de telecomunicações de interesse coletivo prestado no regime privado, cuja recepção é condicionada à contratação remunerada por assinantes e destinado à distribuição de conteúdos audiovisuais na forma de pacotes, de canais nas modalidades avulsa de programação e avulsa de conteúdo programado e de canais de distribuição obrigatória, por meio de tecnologias, processos, meios eletrônicos e protocolos de comunicação quaisquer.

\section{CAPÍTULO II}

\section{DOS PRINCÍPIOS FUNDAMENTAIS DA COMUNICAÇÃO AUDIOVISUAL DE ACESSO CONDICIONADO}

Art. 3ํㅡ A comunicação audiovisual de acesso condicionado, em todas as suas atividades, será guiada pelos seguintes princípios:

I - liberdade de expressão e de acesso à informação;

II - promoção da diversidade cultural e das fontes de informação, produção e programação;

III - promoção da língua portuguesa e da cultura brasileira;

IV - estímulo à produção independente e regional;

V - estímulo ao desenvolvimento social e econômico do País;

VI - liberdade de iniciativa, mínima intervenção da administração pública e defesa da concorrência por meio da livre, justa e ampla competição e da vedação ao monopólio e oligopólio nas atividades de comunicação audiovisual de acesso condicionado.

Parágrafo único. Adicionam-se aos princípios previstos nos incisos deste artigo aqueles estabelecidos na Convenção sobre a Proteção e Promoção da Diversidade das Expressões Culturais, aprovada pelo Decreto Legislativo $\mathrm{n}^{0} 485$, de 20 de dezembro de 2006.

\section{CAPÍTULO III}

\section{DAS ATIVIDADES DA COMUNICAÇÃO AUDIOVISUAL DE ACESSO CONDICIONADO}

Art. 4ํㅡ São atividades da comunicação audiovisual de acesso condicionado:

I - produção;

II - programação;

III - empacotamento;

IV - distribuição.

$\S 1^{\underline{0}}$ A atuação em uma das atividades de que trata este artigo não implica restrição de atuação nas demais, exceto nos casos dispostos nesta Lei.

$\S 2^{\underline{O}}$ Independentemente do objeto ou da razão social, a empresa que atuar em quaisquer das atividades de que trata este artigo será considerada, conforme o caso, produtora, programadora, empacotadora ou 
distribuidora.

Art. 5ㅇ $\mathrm{O}$ controle ou a titularidade de participação superior a 50\% (cinquenta por cento) do capital total e votante de empresas prestadoras de serviços de telecomunicações de interesse coletivo não poderá ser detido, direta, indiretamente ou por meio de empresa sob controle comum, por concessionárias e permissionárias de radiodifusão sonora e de sons e imagens e por produtoras e programadoras com sede no Brasil, ficando vedado a estas explorar diretamente aqueles serviços. (Vigência)

$\S 1^{\underline{0}}$ O controle ou a titularidade de participação superior a 30\% (trinta por cento) do capital total e votante de concessionárias e permissionárias de radiodifusão sonora e de sons e imagens e de produtoras e programadoras com sede no Brasil não poderá ser detido, direta, indiretamente ou por meio de empresa sob controle comum, por prestadoras de serviços de telecomunicações de interesse coletivo, ficando vedado a estas explorar diretamente aqueles serviços.

$\S 2^{\underline{O}}$ É facultado às concessionárias e permissionárias de radiodifusão sonora e de sons e imagens e a produtoras e programadoras com sede no Brasil, diretamente ou por meio de empresa sobre a qual detenham controle direto, indireto ou sob controle comum, prestar serviços de telecomunicações exclusivamente para concessionárias e permissionárias dos serviços de radiodifusão sonora e de sons e imagens ou transportar conteúdo audiovisual das produtoras ou programadoras com sede no Brasil para entrega às distribuidoras, desde que no âmbito da própria rede.

$\S 3 \underline{\underline{O}}$ É facultado às empresas prestadoras de serviços de telecomunicações de interesse coletivo, diretamente ou por meio de empresa sobre a qual detenham controle direto, indireto ou sob controle comum, controlar produtoras e programadoras com sede no Brasil que exerçam atividades exclusivamente destinadas à comercialização de produtos e serviços para o mercado internacional.

Art. 6으 As prestadoras de serviços de telecomunicações de interesse coletivo, bem como suas controladas, controladoras ou coligadas, não poderão, com a finalidade de produzir conteúdo audiovisual para sua veiculação no serviço de acesso condicionado ou no serviço de radiodifusão sonora e de sons e imagens:

I - adquirir ou financiar a aquisição de direitos de exploração de imagens de eventos de interesse nacional; e

II - contratar talentos artísticos nacionais de qualquer natureza, inclusive direitos sobre obras de autores nacionais.

Parágrafo único. As restrições de que trata este artigo não se aplicam quando a aquisição ou a contratação se destinar exclusivamente à produção de peças publicitárias.

Art. 7ํㅡ É vedada a realização de subsídios cruzados, preços discriminatórios ou práticas comerciais, gerenciais ou contábeis que contribuam para a consecução de lucros ou prejuízos artificialmente construídos que busquem dissimular os reais resultados econômicos ou financeiros obtidos, em quaisquer das atividades de comunicação audiovisual de acesso condicionado de que tratam os incisos I a IV do art. 4물, ainda que esses resultados venham a ser compensados por lucros em outras atividades quaisquer, mesmo que exercidas pela mesma empresa.

Art. $8^{\underline{0}}$ As normas gerais de proteção à ordem econômica são aplicáveis à comunicação audiovisual de acesso condicionado.

\section{CAPÍTULO IV}

\section{DA PRODUÇÃO, PROGRAMAÇÃO E EMPACOTAMENTO DE CONTEÚDO}

Art. 9무 As atividades de produção, programação e empacotamento são livres para empresas constituídas sob as leis brasileiras e com sede e administração no País.

Parágrafo único. As atividades de programação e de empacotamento serão objeto de regulação e fiscalização pela Agência Nacional do Cinema - Ancine no âmbito das competências atribuídas a ela 
pela Medida Provisória nº 2.228-1, de 6 de setembro de 2001.

Art. 10. A gestão, a responsabilidade editorial e as atividades de seleção e direção inerentes à programação e ao empacotamento são privativas de brasileiros natos ou naturalizados há mais de 10 (dez) anos.

$\S 1^{\underline{0}}$ As programadoras e empacotadoras deverão depositar e manter atualizada, na Ancine, relação com a identificação dos profissionais de que trata o caput deste artigo, os documentos e atos societários, inclusive os referentes à escolha dos dirigentes e gestores em exercício, das pessoas físicas e jurídicas envolvidas na sua cadeia de controle, cujas informações deverão ficar disponíveis ao conhecimento público, inclusive pela rede mundial de computadores, excetuadas as consideradas confidenciais pela legislação e regulamentação, cabendo à Agência zelar pelo sigilo destas.

$\S 2^{\underline{0}}$ Para a finalidade de aferição do cumprimento das obrigações previstas nos arts. 16 a 18 desta Lei, as programadoras e empacotadoras deverão publicar, nos seus sítios na rede mundial de computadores, a listagem atualizada dos conteúdos audiovisuais e canais de programação disponibilizados, respectivamente, incluindo sua classificação em conformidade com os tipos definidos nesta Lei.

$\S 3^{\underline{0}}$ Para efeito do cumprimento do disposto no Capítulo V, a Ancine poderá solicitar à programadora documentos comprobatórios de que o conteúdo exibido é brasileiro, incluindo o Certificado de Produto Brasileiro, para os casos de que trata a Medida Provisória n 2.228-1, de 6 de setembro de 2001.

Art. 11. Nenhum conteúdo veiculado por meio do Serviço de Acesso Condicionado será exibido sem aviso, antes de sua apresentação, de classificação informando a natureza do conteúdo e as faixas etárias a que não se recomende.

$\S 1^{\underline{0}}$ O Ministério da Justiça fiscalizará o disposto no caput e oficiará à Ancine e à Anatel em caso de seu descumprimento.

$\S 2^{\underline{0}}$ A Anatel oficiará às distribuidoras sobre os canais de programação em desacordo com o disposto no caput, cabendo a elas a cessação da distribuição desses canais após o recebimento da comunicação.

$\S 3^{\underline{0}}$ A distribuidora deverá ofertar ao assinante dispositivo eletrônico que permita o bloqueio da recepção dos conteúdos transmitidos.

$\S 4^{\underline{0}}($ VETADO).

Art. 12. O exercício das atividades de programação e empacotamento é condicionado a credenciamento perante a Ancine.

Parágrafo único. A Ancine deverá se pronunciar sobre a solicitação do credenciamento no prazo de até 30 (trinta) dias e, em não havendo manifestação contrária da Ancine nesse período, o credenciamento será considerado válido.

Art. 13. As programadoras e empacotadoras credenciadas pela Ancine deverão prestar as informações solicitadas pela Agência para efeito de fiscalização do cumprimento das obrigações de programação, empacotamento e publicidade.

Parágrafo único. Para efeito de aferição das restrições de capital de que trata esta Lei, além das informações previstas no caput, as programadoras deverão apresentar a documentação relativa à composição do seu capital total e votante, cabendo à Ancine zelar pelo sigilo das informações consideradas confidenciais pela legislação e regulamentação.

Art. 14. O art. $1^{\underline{0}}$ da Medida Provisória no 2.228-1, de 6 de setembro de 2001, passa a vigorar acrescido do seguinte $\S 4 \underline{0}$ :

"Art. 1 은

$\S 4^{\mathrm{o}}$ Para os fins desta Medida Provisória, entende-se por: 
I - serviço de comunicação eletrônica de massa por assinatura: serviço de acesso condicionado de que trata a lei específica sobre a comunicação audiovisual de acesso condicionado;

II - programadoras de obras audiovisuais para o segmento de mercado de serviços de comunicação eletrônica de massa por assinatura: empresas programadoras de que trata a lei específica sobre a comunicação audiovisual de acesso condicionado." (NR)

Art. 15. $\mathrm{O}$ art. $7 \underline{\mathrm{O}}$ da Medida Provisória $\mathrm{n}^{\circ}$ 2.228-1, de 6 de setembro de 2001, passa a vigorar acrescido dos seguintes incisos XVIII a XXI:

“Art. 7으

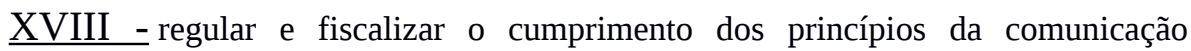
audiovisual de acesso condicionado, das obrigações de programação, empacotamento e publicidade e das restrições ao capital total e votante das produtoras e programadoras fixados pela lei que dispõe sobre a comunicação audiovisual de acesso condicionado;

XIX - elaborar e tornar público plano de trabalho como instrumento de avaliação da atuação administrativa do órgão e de seu desempenho, estabelecendo os parâmetros para sua administração, bem como os indicadores que permitam quantificar, objetivamente, a sua avaliação periódica, inclusive com relação aos recursos aplicados em fomento à produção de audiovisual;

XX - enviar relatório anual de suas atividades ao Ministério da Cultura e, por intermédio da Presidência da República, ao Congresso Nacional;

XXI - tomar dos interessados compromisso de ajustamento de sua conduta às exigências legais no âmbito de suas competências, nos termos do $\S 6^{0}$ do art. $5^{0}$ da $\underline{\text { Lei } \mathrm{n}^{0} 7.347 \text {, de } 24 \text { de julho de } 1985 .}$

(NR)

\section{CAPÍTULO V \\ DO CONTEÚDO BRASILEIRO}

Art. 16. Nos canais de espaço qualificado, no mínimo 3h30 (três horas e trinta minutos) semanais dos conteúdos veiculados no horário nobre deverão ser brasileiros e integrar espaço qualificado, e metade deverá ser produzida por produtora brasileira independente. (Vigência) (Vigência)

Art. 17. Em todos os pacotes ofertados ao assinante, a cada 3 (três) canais de espaço qualificado existentes no pacote, ao menos 1 (um) deverá ser canal brasileiro de espaço qualificado. (Vigência) (Vigência)

$\S 1^{\underline{0}}$ Da parcela mínima de canais brasileiros de espaço qualificado de que trata o caput, pelo menos $1 / 3$ (um terço) deverá ser programado por programadora brasileira independente.

$\S 2 \underline{0}$ A empacotadora estará obrigada a cumprir o disposto no caput até o limite de 12 (doze) canais brasileiros de espaço qualificado.

$\S 3^{\underline{0}}$ As empacotadoras que ofertarem pacotes distribuídos por tecnologias que possibilitem distribuir, no máximo, pacotes com até 31 (trinta e um) canais de programação estarão obrigadas a cumprir o disposto no caput deste artigo até o limite de 3 (três) canais, bem como serão dispensadas do cumprimento do disposto no art. 18 .

$\S 4^{\underline{0}}$ Dos canais brasileiros de espaço qualificado a serem veiculados nos pacotes, ao menos 2 (dois) canais deverão veicular, no mínimo, 12 (doze) horas diárias de conteúdo audiovisual brasileiro produzido por produtora brasileira independente, 3 (três) das quais em horário nobre.

$\S 5^{\underline{0}}$ A programadora de pelo menos um dos canais de que trata o $\S 4^{\underline{0}}$ não poderá ser controlada, 
controladora ou coligada a concessionária de serviço de radiodifusão de sons e imagens.

Art. 18. Nos pacotes em que houver canal de programação gerado por programadora brasileira que possua majoritariamente conteúdos jornalísticos no horário nobre, deverá ser ofertado pelo menos um canal adicional de programação com as mesmas características no mesmo pacote ou na modalidade avulsa de programação, observado o disposto no $\S 4^{\underline{0}}$ do art. 19. (Vide artigo $37 \S 4^{\circ}$ ) (Vide artigo 40) (Vide artigo 41)

Parágrafo único. As programadoras dos canais de que trata o caput deste artigo não poderão deter relação de controle ou coligação entre si.

Art. 19. Para efeito do cumprimento do disposto nos arts. 16 e 17, serão desconsiderados: (Vigência)

I - os canais de programação de distribuição obrigatória de que trata o art. 32, ainda que veiculados em localidade distinta daquela em que é distribuído o pacote;

II - os canais de programação que retransmitirem canais de geradoras detentoras de outorga de radiodifusão de sons e imagens em qualquer localidade;

III - os canais de programação operados sob a responsabilidade do poder público;

IV - os canais de programação cuja grade de programação não tenha passado por qualquer modificação para se adaptar ao público brasileiro, incluindo legendagem, dublagem para língua portuguesa ou publicidade específica para o mercado brasileiro;

V - os canais de programação dedicados precipuamente à veiculação de conteúdos de cunho erótico;

VI - os canais ofertados na modalidade avulsa de programação;

VII - os canais de programação ofertados em modalidade avulsa de conteúdo programado.

$\S 1^{\underline{O}}$ Para os canais de que trata o inciso VI, aplica-se o disposto no art. 16.

$\S 2^{\underline{O}}$ Na oferta dos canais de que trata o inciso VII, no mínimo 10\% (dez por cento) dos conteúdos ofertados que integrarem espaço qualificado deverão ser brasileiros.

$\S 3^{\underline{O}}$ O cumprimento da obrigação de que trata o $\S 2^{\underline{O}}$ será aferido em conformidade com período de apuração estabelecido pela Ancine.

$\S 4^{\underline{O}}$ Para efeito do cumprimento do disposto no art. 18, serão desconsiderados os canais de que tratam os incisos III, IV, V e VII do caput deste artigo.

Art. 20. A programadora ou empacotadora, no cumprimento das obrigações previstas nos arts. 16 a 18, observará as seguintes condições: (Vigência)

I - pelo menos a metade dos conteúdos audiovisuais deve ter sido produzida nos 7 (sete) anos anteriores à sua veiculação; (Vigência)

II - o conteúdo produzido por brasileiro nato ou naturalizado há mais de 10 (dez) anos será equiparado ao produzido por produtora brasileira;

III - o conteúdo produzido por brasileiro nato ou naturalizado há mais de 10 (dez) anos será equiparado ao produzido por produtora brasileira independente, caso seu produtor atenda as condições previstas na alínea "c" do inciso XIX do art. 2무;

IV - quando o cálculo dos percentuais e razões não resultar em número inteiro exato, considerar-se-á a parte inteira do resultado.

Art. 21. Em caso de comprovada impossibilidade de cumprimento integral do disposto nos arts. 16 a 18, o interessado deverá submeter solicitação de dispensa à Ancine, que, caso reconheça a impossibilidade alegada, pronunciar-se-á sobre as condições e limites de cumprimento desses artigos. (Vigência)

Art. 22. Regulamentação da Ancine disporá sobre a fixação do horário nobre, respeitado o limite máximo de 7 (sete) horas diárias para canais de programação direcionados para crianças e adolescentes e de 6 (seis) horas 
para os demais canais de programação. (Vigência)

Art. 23. Nos 2 (dois) primeiros anos de vigência desta Lei, o número de horas de que trata o caput do art. 16 , as resultantes das razões estipuladas no caput e no $\S 1^{\underline{0}}$ do art. 17 e o limite de que trata o $\S 3^{\underline{0}}$ do art. 17 serão reduzidos nas seguintes razões: (Vigência)

I - 2/3 (dois terços) no primeiro ano de vigência da Lei;

II - 1/3 (um terço) no segundo ano de vigência da Lei.

Art. 24. O tempo máximo destinado à publicidade comercial em cada canal de programação deverá ser igual ao limite estabelecido para o serviço de radiodifusão de sons e imagens.

Parágrafo único. O disposto no caput deste artigo não se aplica aos canais de que trata o art. 32 desta Lei e aos canais exclusivos de publicidade comercial, de vendas e de infomerciais.

Art. 25. Os programadores não poderão ofertar canais que contenham publicidade de serviços e produtos em língua portuguesa, legendada em português ou de qualquer forma direcionada ao público brasileiro, com veiculação contratada no exterior, senão por meio de agência de publicidade nacional.

$\S 1^{\underline{0}}$ A Ancine fiscalizará o disposto no caput e oficiará à Anatel e à Secretaria da Receita Federal do Brasil em caso de seu descumprimento.

$\S 2^{\underline{0}}$ A Anatel oficiará às distribuidoras sobre os canais de programação em desacordo com o disposto no $\S 1^{\underline{0}}$, cabendo a elas a cessação da distribuição desses canais após o recebimento da comunicação.

\section{CAPÍTULO VI}

\section{DO ESTÍMULO À PRODUÇÃO AUDIOVISUAL}

Art. 26. $\mathrm{O}$ Anexo I da Medida Provisória $\mathrm{n}^{0}$ 2.228-1, de 6 de setembro de 2001, passa a vigorar acrescido do quadro constante do Anexo desta Lei, e seus arts. 32, 33, 35, 36, 38 e 39 passam a vigorar com a seguinte redação, renumerando-se o parágrafo único do art. 38 para $\S 1^{\circ}-$. (Produção de efeito)

“Art. 32. A Contribuição para o Desenvolvimento da Indústria Cinematográfica Nacional - Condecine terá por fato gerador:

I - a veiculação, a produção, o licenciamento e a distribuição de obras cinematográficas e videofonográficas com fins comerciais, por segmento de mercado a que forem destinadas;

II - a prestação de serviços que se utilizem de meios que possam, efetiva ou potencialmente, distribuir conteúdos audiovisuais nos termos da lei que dispõe sobre a comunicação audiovisual de acesso condicionado, listados no Anexo I desta Medida Provisória;

III - a veiculação ou distribuição de obra audiovisual publicitária incluída em programação internacional, nos termos do inciso XIV do art. $1^{\underline{0}}$ desta Medida Provisória, nos casos em que existir participação direta de agência de publicidade nacional, sendo tributada nos mesmos valores atribuídos quando da veiculação incluída em programação nacional.

(NR)

“Art. 33. A Condecine será devida para cada segmento de mercado, por:

II - título de obra publicitária cinematográfica ou videofonográfica, para cada segmento dos mercados previstos nas alíneas "a" a "e" do inciso I a que se destinar; III - prestadores dos serviços constantes do Anexo I desta Medida Provisória, a que se refere o inciso II do art. 32 desta Medida Provisória. 
$\S 3^{0}$ A Condecine será devida:

I - uma única vez a cada 5 (cinco) anos, para as obras a que se refere o inciso I do caput deste artigo;

II - a cada 12 (doze) meses, para cada segmento de mercado em que a obra seja efetivamente veiculada, para as obras a que se refere o inciso II do caput deste artigo;

III - a cada ano, para os serviços a que se refere o inciso III do caput deste artigo.

$\S 4^{\underline{0}}$ Na ocorrência de modalidades de serviços qualificadas na forma do inciso II do art. 32 não presentes no Anexo I desta Medida Provisória, será devida pela prestadora a Contribuição referente ao item "a" do Anexo I, até que lei fixe seu valor.” (NR)

“Art. 35.

…

III - o responsável pelo pagamento, crédito, emprego, remessa ou entrega das importâncias referidas no parágrafo único do art. 32;

IV - as concessionárias, permissionárias e autorizadas de serviços de telecomunicações, relativamente ao disposto no inciso II do art. 32;

V - o representante legal e obrigatório da programadora estrangeira no País, na hipótese do inciso III do art. 32.” (NR)

“Art. 36.

$\cdots$

VII - anualmente, até o dia 31 de março, para os serviços de que trata o inciso II do art. 32 desta Medida Provisória.” (NR)

“Art.

38.

$\S$

$1 \underline{\underline{0}}$

$\S 2^{\circ}$ A Ancine e a Agência Nacional de Telecomunicações - Anatel exercerão as atividades de regulamentação e fiscalização no âmbito de suas competências e poderão definir o recolhimento conjunto da parcela da Condecine devida referente ao inciso III do caput do art. 33 e das taxas de fiscalização de que trata a Lei n- 5.070, de 7 de julho de 1966, que cria o Fundo de Fiscalização das Telecomunicações.” (NR)

“Art. 39.

XI - a Anatel, as Forças Armadas, a Polícia Federal, as Polícias Militares, a Polícia Rodoviária Federal, as Polícias Civis e os Corpos de Bombeiros Militares.

Art. 27. O art. $4^{\underline{0}}$ da Lei $n^{\underline{O}} 11.437$, de 28 de dezembro de 2006, passa a vigorar com a seguinte redação: (Produção de efeito)

“ Art. $4^{\text {O }}$

$\S 3^{\circ}$ As receitas de que trata o inciso III do caput do art. 33 da Medida Provisória n ${ }^{\circ}$ 2.228-1, de 6 de setembro de 2001, deverão ser utilizadas nas seguintes condições:

I - no mínimo, 30\% (trinta por cento) deverão ser destinadas a produtoras brasileiras 
estabelecidas nas regiões Norte, Nordeste e Centro-Oeste, nos critérios e condições estabelecidos pela Agência Nacional do Cinema - Ancine, que deverão incluir, entre outros, o local da produção da obra audiovisual, a residência de artistas e técnicos envolvidos na produção e a contratação, na região, de serviços técnicos a ela vinculados;

II - no mínimo, 10\% (dez por cento) deverão ser destinadas ao fomento da produção de conteúdo audiovisual independente veiculado primeiramente nos canais comunitários, universitários e de programadoras brasileiras independentes de que trata a lei que dispõe sobre a comunicação audiovisual de acesso condicionado.

$\S 4^{\underline{0}}$ Para efeito do disposto no $\S 3^{\underline{0}}$ deste artigo, entende-se como produtora brasileira aquela definida nos termos da lei específica que dispõe sobre a comunicação audiovisual de acesso condicionado.” (NR)

Art. 28. O caput do art. $8^{\underline{0}}$ da Lei $n^{\underline{0}} 5.070$, de 7 de julho de 1966 , passa a vigorar com a seguinte redação: (Produção de efeito)

“Art. $8^{\mathrm{O}}$ A Taxa de Fiscalização de Funcionamento será paga, anualmente, até o dia 31 de março, e seus valores serão os correspondentes a 33\% (trinta e três por cento) dos fixados para a Taxa de Fiscalização de Instalação.

\section{CAPÍTULO VII}

\section{DA DISTRIBUIÇÃO DE CONTEÚDO PELAS PRESTADORAS DO SERVIÇO DE ACESSO CONDICIONADO}

Art. 29. A atividade de distribuição por meio do serviço de acesso condicionado é livre para empresas constituídas sob as leis brasileiras, com sede e administração no País, sendo regida pelas disposições previstas nesta Lei, na Lei $n^{0}$ 9.472, de 16 de julho de 1997, e na regulamentação editada pela Agência Nacional de Telecomunicações - Anatel.

Parágrafo único. A Anatel regulará e fiscalizará a atividade de distribuição.

Art. 30. As distribuidoras e empacotadoras não poderão, diretamente ou por intermédio de suas controladas, controladoras ou coligadas inserir ou associar qualquer tipo de publicidade ou conteúdo audiovisual nos canais de programação ou nos conteúdos audiovisuais avulsos veiculados sem a prévia e expressa autorização do titular do canal de programação ou do conteúdo a ser veiculado, respectivamente.

Art. 31. As prestadoras do serviço de acesso condicionado somente poderão distribuir conteúdos empacotados por empresa regularmente credenciada pela Ancine, observado o $§ 2^{\underline{0}}$ do art. $4^{\underline{0}}$ desta Lei.

$\S 1^{\underline{0}}$ As prestadoras do serviço de acesso condicionado deverão tornar pública a empacotadora do pacote por ela distribuído.

$\S 2^{\underline{0}}$ A distribuidora não poderá ofertar aos assinantes pacotes que estiverem em desacordo com esta Lei.

Art. 32. A prestadora do serviço de acesso condicionado, em sua área de prestação, independentemente de tecnologia de distribuição empregada, deverá tornar disponíveis, sem quaisquer ônus ou custos adicionais para seus assinantes, em todos os pacotes ofertados, canais de programação de distribuição obrigatória para as seguintes destinações:

I - canais destinados à distribuição integral e simultânea, sem inserção de qualquer informação, do sinal aberto e não codificado, transmitido em tecnologia analógica pelas geradoras locais de radiodifusão de sons e imagens, em qualquer faixa de frequências, nos limites territoriais da área de cobertura da concessão;

II - um canal reservado para a Câmara dos Deputados, para a documentação dos seus trabalhos, especialmente a transmissão ao vivo das sessões;

III - um canal reservado para o Senado Federal, para a documentação dos seus trabalhos, especialmente a transmissão ao vivo das sessões;

IV - um canal reservado ao Supremo Tribunal Federal, para a divulgação dos atos do Poder Judiciário e 
dos serviços essenciais à Justiça;

V - um canal reservado para a prestação de serviços de radiodifusão pública pelo Poder Executivo, a ser utilizado como instrumento de universalização dos direitos à informação, à comunicação, à educação e à cultura, bem como dos outros direitos humanos e sociais;

VI - um canal reservado para a emissora oficial do Poder Executivo;

VII - um canal educativo e cultural, organizado pelo Governo Federal e destinado para o desenvolvimento e aprimoramento, entre outros, do ensino a distância de alunos e capacitação de professores, assim como para a transmissão de produções culturais e programas regionais;

VIII - um canal comunitário para utilização livre e compartilhada por entidades não governamentais e sem fins lucrativos;

IX - um canal de cidadania, organizado pelo Governo Federal e destinado para a transmissão de programações das comunidades locais, para divulgação de atos, trabalhos, projetos, sessões e eventos dos poderes públicos federal, estadual e municipal;

$\mathrm{X}$ - um canal legislativo municipal/estadual, reservado para o uso compartilhado entre as Câmaras de Vereadores localizadas nos Municípios da área de prestação do serviço e a Assembleia Legislativa do respectivo Estado ou para uso da Câmara Legislativa do Distrito Federal, destinado para a divulgação dos trabalhos parlamentares, especialmente a transmissão ao vivo das sessões;

XI - um canal universitário, reservado para o uso compartilhado entre as instituições de ensino superior localizadas no Município ou Municípios da área de prestação do serviço, devendo a reserva atender a seguinte ordem de precedência:

a) universidades;

b) centros universitários;

c) demais instituições de ensino superior.

$\S 1^{\underline{O}}$ A programação dos canais previstos nos incisos II e III deste artigo poderá ser apresentada em um só canal, se assim o decidir a Mesa do Congresso Nacional.

$\S 2^{\underline{0}}$ A cessão às distribuidoras das programações das geradoras de que trata o inciso I deste artigo será feita a título gratuito e obrigatório.

$\S 3^{\underline{0}}$ A distribuidora do serviço de acesso condicionado não terá responsabilidade sobre o conteúdo da programação veiculada nos canais previstos neste artigo nem estará obrigada a fornecer infraestrutura para as atividades de produção, programação ou empacotamento.

$\S 4^{\underline{0}}$ As programadoras dos canais de que tratam os incisos II a XI deste artigo deverão viabilizar, a suas expensas, a entrega dos sinais dos canais nas instalações indicadas pelas distribuidoras, nos termos e condições técnicas estabelecidos pela Anatel.

$\S 5^{\underline{O}}$ Os canais previstos nos incisos II a XI deste artigo não terão caráter privado, sendo vedadas a veiculação remunerada de anúncios e outras práticas que configurem comercialização de seus intervalos, assim como a transmissão de publicidade comercial, ressalvados os casos de patrocínio de programas, eventos e projetos veiculados sob a forma de apoio cultural.

$\S 6^{\underline{0}}$ Os canais de que trata este artigo deverão ser ofertados em bloco e em ordem numérica virtual sequencial, sendo vedado intercalá-los com outros canais de programações, respeitada a ordem de alocação dos canais no serviço de radiodifusão de sons e imagens, inclusive em tecnologia digital, de cada localidade.

$\S 7 \underline{0}$ Em caso de inviabilidade técnica ou econômica, o interessado estará desobrigado do cumprimento do disposto no $\S 6^{\underline{0}}$ deste artigo e deverá comunicar o fato à Anatel, que deverá ou não aquiescer no prazo de 90 (noventa) dias do comunicado, sob pena de aceitação tácita mediante postura silente em função de decurso de prazo. 
$\S 8^{0}$ O Em casos de inviabilidade técnica ou econômica comprovada, a Anatel determinará a não obrigatoriedade da distribuição de parte ou da totalidade dos canais de que trata este artigo nos meios de distribuição considerados inapropriados para o transporte desses canais em parte ou na totalidade das localidades servidas pela distribuidora.

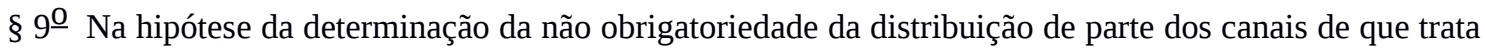
este artigo, a Anatel disporá sobre quais canais de programação deverão ser ofertados pelas distribuidoras aos usuários, observando-se a isonomia entre os canais de que trata o inciso I deste artigo de uma mesma localidade, priorizando após as geradoras locais de conteúdo nacional ao menos um canal religioso em cada localidade, caso existente, na data da promulgação desta Lei.

$\S 10$. Ao distribuir os canais de que trata este artigo, a prestadora do serviço de acesso condicionado não poderá efetuar alterações de qualquer natureza nas programações desses canais.

$\S 11$. O disposto neste artigo não se aplica aos distribuidores que ofertarem apenas modalidades avulsas de conteúdo.

$\S 12$. A geradora local de radiodifusão de sons e imagens de caráter privado poderá, a seu critério, ofertar sua programação transmitida com tecnologia digital para as distribuidoras de forma isonômica e não discriminatória, nas condições comerciais pactuadas entre as partes e nos termos técnicos estabelecidos pela Anatel, ficando, na hipótese de pactuação, facultada à prestadora do serviço de acesso condicionado a descontinuidade da transmissão da programação com tecnologia analógica prevista no inciso I deste artigo.

$\S 13$. Caso não seja alcançado acordo quanto às condições comerciais de que trata o $\S 12$, a geradora local de radiodifusão de sons e imagens de caráter privado poderá, a seu critério, exigir que sua programação transmitida com tecnologia digital seja distribuída gratuitamente na área de prestação do serviço de acesso condicionado, desde que a tecnologia de transmissão empregada pelo distribuidor e de recepção disponível pelo assinante assim o permitam, de acordo com critérios estabelecidos em regulamentação da Anatel.

$\S$ 14. Na hipótese de que trata o § 13, a cessão da programação em tecnologia digital não ensejará pagamento por parte da distribuidora, que ficará desobrigada de ofertar aos assinantes a programação em tecnologia analógica.

$\S 15$. Equiparam-se às geradoras de que trata o inciso I deste artigo as retransmissoras habilitadas a operar em regiões de fronteira de desenvolvimento do País que realizarem inserções locais de programação e publicidade, inclusive as que operarem na Amazônia Legal.

$\S 16$. É facultado à geradora de radiodifusão que integre rede nacional proibir que seu sinal seja distribuído mediante serviço de acesso condicionado fora dos limites territoriais de sua área de concessão, bem como vedar que o sinal de outra geradora integrante da mesma rede seja distribuído mediante serviço de acesso condicionado nos limites territoriais alcançados pela transmissão de seus sinais via radiodifusão.

$\S 17$. Na distribuição dos canais de que trata este artigo, deverão ser observados os critérios de qualidade técnica estabelecidos pela Anatel, sendo que, para os canais de que trata o inciso I, é de exclusiva responsabilidade da prestadora do serviço de acesso condicionado a recepção do sinal das geradoras para sua distribuição aos assinantes.

$\S$ 18. A Anatel regulamentará os critérios de compartilhamento do canal de que trata o inciso XI entre entidades de uma mesma área de prestação de serviço.

$\S$ 19. A programação dos canais previstos nos incisos VIII e IX deste artigo poderá ser apresentada em um só canal, se assim o decidirem os responsáveis por esses canais.

$\S 20$. A dispensa da obrigação de distribuição de canais nos casos previstos no $\S 8^{0}$ deverá ser solicitada pela interessada à Anatel, que deverá se manifestar no prazo de 90 (noventa) dias do recebimento da solicitação, sob pena de aceitação tácita mediante postura silente em função de decurso de prazo.

$\S 21$. Nas localidades onde não houver concessão para exploração do serviço de radiodifusão de sons e imagens, caso o sinal de geradora ou retransmissora de radiodifusão de sons e imagens em tecnologia analógica alcance os limites territoriais dessa localidade, a distribuidora deverá distribuir esse sinal, vedada a distribuição 
de programação coincidente e observado o disposto nos $\S \S 7 \underline{0}$ a $9 \underline{\underline{O}}_{\mathrm{e}} 16$.

\section{CAPÍTULO VIII}

\section{DOS ASSINANTES DO SERVIÇO DE ACESSO CONDICIONADO}

Art. 33. São direitos do assinante do serviço de acesso condicionado, sem prejuízo do disposto na Lei $\underline{n^{0}} 8.078$, de 11 de setembro de 1990 (Código de Defesa do Consumidor), e nas demais normas aplicáveis às relações de consumo e aos serviços de telecomunicações:

I - conhecer, previamente, o tipo de programação a ser exibida;

II - contratar com a distribuidora do serviço de acesso condicionado os serviços de instalação e manutenção dos equipamentos necessários à recepção dos sinais;

III - (VETADO);

IV - relacionar-se apenas com a prestadora do serviço de acesso condicionado da qual é assinante;

V - receber cópia impressa ou em meio eletrônico dos contratos assim que formalizados;

VI - ter a opção de contratar exclusivamente, de forma onerosa, os canais de distribuição obrigatória de que trata o art. 32.

Art. 34. As prestadoras do serviço de acesso condicionado deverão atender os usuários em bases não discriminatórias, exceto se a discriminação for necessária para o alcance de objetivos sociais relevantes suportados por políticas públicas que a justifiquem.

\section{CAPÍTULO IX}

\section{DAS SANÇÕES E PENALIDADES}

Art. 35. O não cumprimento do disposto nesta Lei por prestadora do serviço de acesso condicionado implicará a aplicação das penalidades previstas na Lei n ${ }^{0}$ 9.472, de 16 de julho de 1997.

Art. 36. A empresa no exercício das atividades de programação ou empacotamento da comunicação audiovisual de acesso condicionado que descumprir quaisquer das obrigações dispostas nesta Lei sujeitar-se-á às seguintes sanções aplicáveis pela Ancine, sem prejuízo de outras previstas em lei, inclusive as de natureza civil e penal:

I - advertência;

II - multa, inclusive diária;

III - suspensão temporária do credenciamento;

IV - cancelamento do credenciamento.

$\S 1^{\underline{0}} \mathrm{Na}$ aplicação de sanções, serão considerados a natureza e a gravidade da infração, os danos dela resultantes para os assinantes, a vantagem auferida pelo infrator, as circunstâncias agravantes, os antecedentes do infrator e a reincidência específica, entendida como a repetição de falta de igual natureza após decisão administrativa anterior.

$\S 2^{\underline{0}}$ Nas infrações praticadas por pessoa jurídica, também serão punidos com a sanção de multa seus administradores ou controladores, quando tiverem agido de má-fé.

$\S 3^{\underline{0}}$ A existência de sanção anterior será considerada como agravante na aplicação de outra sanção.

$\S 4 \underline{0}$ A multa poderá ser imposta isoladamente ou em conjunto com outra sanção, não devendo ser inferior a R\$ 2.000,00 (dois mil reais) nem superior a $\mathrm{R} \$$ 5.000.000,00 (cinco milhões de reais) para cada infração cometida.

§ 5ํㅡ $\mathrm{Na}$ aplicação de multa, serão considerados a condição econômica do infrator e o princípio da proporcionalidade entre a gravidade da falta e a intensidade da sanção.

$\S 6^{\underline{0}}$ A suspensão temporária do credenciamento, que não será superior a 30 (trinta) dias, será imposta em 
caso de infração grave cujas circunstâncias não justifiquem o cancelamento do credenciamento.

CAPÍTULO X

\section{DISPOSIÇÕES FINAIS E TRANSITÓRIAS}

Art. 37. Revogam-se o art. 31 da Medida Provisória n 2.228-1, de 6 de setembro de 2001, e os dispositivos constantes dos Capítulos I a IV, VI e VIII a XI da Lei $\mathrm{n}^{0}$ 8.977, de 6 de janeiro de 1995.

$\S 1^{\underline{0}}$ Os atos de outorga de concessão e respectivos contratos das atuais prestadoras do Serviço de TV a Cabo - TVC, os termos de autorização já emitidos para as prestadoras do Serviço de Distribuição de Canais Multiponto Multicanal - MMDS e do Serviço de Distribuição de Sinais de Televisão e de Áudio por Assinatura Via Satélite - DTH, assim como os atos de autorização de uso de radiofrequência das prestadoras do MMDS e do Serviço Especial de Televisão por Assinatura - TVA, continuarão em vigor, sem prejuízo da adaptação aos condicionamentos relativos à programação e empacotamento previstos no Capítulo $\mathrm{V}$, até o término dos prazos de validade neles consignados, respeitada a competência da Anatel quanto à regulamentação do uso e à administração do espectro de radiofrequências, devendo a Agência, no que couber, adequar a regulamentação desses serviços às disposições desta Lei.

$\S 2^{\underline{0}}$ A partir da aprovação do regulamento do serviço de acesso condicionado, as atuais prestadoras de TVC, MMDS, DTH e TVA, desde que preenchidas as condições objetivas e subjetivas necessárias, poderão solicitar à Anatel a adaptação das respectivas outorgas para termos de autorização para prestação do serviço de acesso condicionado, assegurando-se o direito de uso de radiofrequência pelos prazos remanescentes, na forma prevista na legislação pertinente e na regulamentação editada pela Anatel, em especial a de uso da radiofrequência.

$\S 3^{\underline{0}}$ As prestadoras de TVC, MMDS, DTH e TVA que tiverem suas outorgas adaptadas para prestação do serviço de acesso condicionado deverão assegurar a continuidade da prestação dos serviços aos seus assinantes, com preços similares ou inferiores aos por elas praticados, na mesma área de prestação dos serviços.

$\S 4 \underline{\underline{O}}$ O disposto nos arts. 16 a 18 desta Lei será aplicado a partir de 180 (cento e oitenta) dias da data de vigência desta Lei a todas as empresas que exerçam atividades de programação ou empacotamento, inclusive aquelas cujos canais ou pacotes sejam distribuídos mediante os serviços de TVC, MMDS, DTH e TVA, independentemente das obrigações dispostas nos demais parágrafos deste artigo relativas à atividade de distribuição mediante serviço de acesso condicionado, TVC, MMDS, DTH e TVA.

$\S 5^{\underline{0}}$ Não serão devidas compensações financeiras às prestadoras dos serviços mencionados no $\S 1 \underline{\underline{0}}$ nos casos de adaptação de outorgas de que trata este artigo.

$\S 6^{\underline{0}}$ Até a aprovação do regulamento do serviço de acesso condicionado, só serão admitidas pela Anatel renovações de outorgas, de autorização do direito de uso de radiofequências, alterações na composição societária da prestadora, bem como transferências de outorgas, de controle ou demais alterações de instrumentos contratuais referentes à prestação dos serviços mencionados no $\S 1$ - para prestadoras que se comprometerem com a Anatel a promover a adaptação de seus instrumentos de outorga para o serviço de acesso condicionado imediatamente após a aprovação do regulamento, que conterá os critérios de adaptação.

$\S 7 \underline{0}$ Após a aprovação do regulamento do serviço de acesso condicionado pela Anatel, só serão admitidas renovações e transferências de outorgas, de controle, renovações de autorização do direito de uso de radiofrequência, alterações na composição societária da prestadora ou demais alterações de instrumentos contratuais referentes à prestação dos serviços mencionados no $\S 1 \underline{\underline{0}}$ para prestadoras que adaptarem seus instrumentos de outorga para o serviço de acesso condicionado.

$\S 8^{\underline{0}}$ A partir da aprovação desta Lei, não serão outorgadas novas concessões ou autorizações para a prestação dos serviços de TVC, DTH, MMDS e TVA. 
$\S 9^{\underline{0}}$ A outorga para a prestação do serviço de acesso condicionado estará condicionada à não detenção de outorgas para os serviços de TV a Cabo - TVC, de Distribuição de Canais Multiponto Multicanal - MMDS, de Distribuição de Sinais de Televisão e de Áudio por Assinatura Via Satélite - DTH ou Especial de Televisão por Assinatura - TVA pela interessada ou por suas controladas, controladoras ou coligadas, bem como à adaptação de todas as outorgas da interessada e de suas controladas, controladoras ou coligadas para termos de autorização para prestação do serviço de acesso condicionado, nos termos dos $\S \S 2 \underline{\underline{0}}$ e $6 \underline{0}$.

$\S 10$. A Anatel deverá adotar as medidas necessárias para o tratamento da solicitação de que tratam os $\S \S$ $2^{\underline{O}}$ e $6^{\underline{O}}$ e se pronunciar sobre ela no prazo máximo de 90 (noventa) dias do seu recebimento.

$\S 11$. As atuais concessões para a prestação de TVA cujos atos de autorização de uso de radiofrequência estejam em vigor, ou dentro de normas e regulamentos editados pela Anatel, até a data da promulgação desta Lei, poderão ser adaptadas para prestação do serviço de acesso condicionado, nas condições estabelecidas nesta Lei, permanecendo, neste caso, vigentes os atos de autorização de uso de radiofrequência associados pelo prazo remanescente da outorga, contado da data de vencimento de cada outorga individualmente, não sendo objeto de renovação adicional.

$\S$ 12. Não se aplica o disposto nos arts. $5 \underline{\underline{0}}$ e $6 \underline{0}$ aos detentores de autorizações para a prestação de TVA.

$\S 13$. O disposto nos $\S \S 1^{\underline{0}}, 2^{\underline{O}}$ e 11 deste artigo não retira da Anatel a competência para alterar a destinação de radiofrequências ou faixas prevista no art. 161 da Lei no 9.472, de 16 de julho de 1997.

$\S 14$. As solicitações de que tratam os $\S \S 2^{\underline{O}}$ e $6^{\underline{O}}$ serão consideradas automaticamente aprovadas caso a Anatel não se pronuncie sobre elas no prazo estabelecido no § 10.

§ 15. O art. 24 da Lei $\mathrm{n}^{\mathrm{O}}$ 8.977, de 6 de janeiro de 1995, passa a vigorar com a seguinte redação:

“Art. 24. Excluídos os canais referidos nos incisos I, II e III do art. 23, os demais canais serão contratados livremente pela operadora de TV a Cabo à empacotadora ou programadora de sua escolha." (NR)

$\S 16$. Aplicam-se às distribuidoras dos serviços de TVC, MMDS e DTH o disposto nos incisos XIX e XXII do art. $2^{\underline{0}}$, nos $\S \S 1^{\underline{0}}$ e $2^{\underline{0}}$ do art. $4^{\underline{0}}$ e nos arts. $7^{\underline{0}}, 8^{\circ} \underline{\underline{O}}, 11,30$ e 31 desta Lei.

$\S 17$. No caso das prestadoras de TVC, para efeito do cumprimento do disposto nos arts. 16 a 18 desta

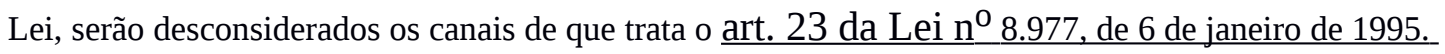

$\S$ 18. A concessionária do STFC - Serviço Telefônico Fixo Comutado poderá solicitar, a qualquer tempo, a adequação do contrato de concessão para eliminação das restrições que vedem a possibilidade de que a concessionária do serviço e suas coligadas, controladas ou controladoras prestem serviço de TVC, inclusive nas áreas geográficas de prestação do serviço objeto da referida concessão, desde que se comprometam com a adaptação obrigatória de que tratam os $\S \S 2^{\underline{0}}, 6^{\underline{0}}, 7^{\underline{0}}$ e $9^{\underline{0}}$.

$\S 19$. A Anatel adotará todas as medidas necessárias para o tratamento da solicitação de que trata o $\S 18$, publicando formalmente o ato de aprovação quanto ao solicitado no prazo máximo de 90 (noventa) dias do seu recebimento.

$\S 20$. O disposto no art. 32 aplica-se aos serviços de TVC, MMDS e DTH.

Art. 38. O art. 86 da Lei no 9.472 , de 16 de julho de 1997, passa a vigorar com a seguinte redação:

“Art. 86. A concessão somente poderá ser outorgada a empresa constituída segundo as leis brasileiras, com sede e administração no País, criada para explorar exclusivamente serviços de telecomunicações.

Parágrafo único. Os critérios e condições para a prestação de outros serviços de telecomunicações diretamente pela concessionária obedecerão, entre outros, aos seguintes princípios, de acordo com regulamentação da Anatel:

I - garantia dos interesses dos usuários, nos mecanismos de reajuste e revisão das 
tarifas, mediante o compartilhamento dos ganhos econômicos advindos da racionalização decorrente da prestação de outros serviços de telecomunicações, ou ainda mediante a transferência integral dos ganhos econômicos que não decorram da eficiência ou iniciativa empresarial, observados os termos dos $\S \S 2^{\underline{0}}$ e $3^{\underline{0}}$ do art. 108 desta Lei;

II - atuação do poder público para propiciar a livre, ampla e justa competição, reprimidas as infrações da ordem econômica, nos termos do art. $6^{\underline{0}}$ desta Lei;

III - existência de mecanismos que assegurem o adequado controle público no que tange aos bens reversíveis.” (NR)

$\S 1$ $\underline{0}$ A concessionária do STFC poderá solicitar, a qualquer tempo, a adequação do contrato de concessão às disposições deste artigo.

$\S 2 \underline{\underline{O}}$ A Anatel deverá adotar as medidas necessárias para o tratamento da solicitação de que trata o $\S 1$ e e pronunciar-se sobre ela em até 90 (noventa) dias do seu recebimento, cabendo à Anatel, se for o caso, promover as alterações necessárias ao contrato de concessão, considerando-se os critérios e condições previstos no parágrafo único do art. 86 da Lei n ${ }^{\circ}$ 9.472, de 16 de julho de 1997.

Art. 39. As prestadoras dos serviços de TV a Cabo - TVC, de Distribuição de Canais Multiponto Multicanal - MMDS, de Distribuição de Sinais de Televisão e de Áudio por Assinatura Via Satélite - DTH e Especial de Televisão por Assinatura - TVA, bem como suas controladas, controladoras ou coligadas, não poderão fazer uso de recursos do Fundo Nacional da Cultura, criado pela Lei $\mathrm{n}^{0} 7.505$, de 2 de julho de 1986, restabelecido pela Lei $\mathrm{n}^{0}$ 8.313, de 23 de dezembro de 1991, ou dos mecanismos de fomento e de

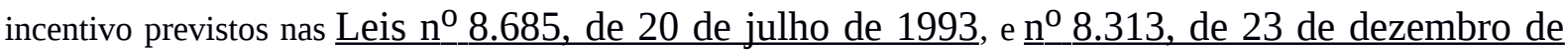
1991.

Art. 40. O art. 5으 passa a viger 1 (um) ano após a promulgação desta Lei; o inciso I do caput do art. 20 passa a viger 4 (quatro) anos após a promulgação desta Lei; o art. 18 passa a viger 1 (um) ano após a promulgação desta Lei e os arts. 26 a 28 produzirão efeitos a partir do ano seguinte à sua publicação.

Art. 41. Os arts. 16 a 23 deixarão de viger após 12 (doze) anos da promulgação desta Lei.

Art. 42. A Anatel e a Ancine, no âmbito de suas respectivas competências, regulamentarão as disposições desta Lei em até 180 (cento e oitenta) dias da sua publicação, ouvido o parecer do Conselho de Comunicação Social.

Parágrafo único. Caso o Conselho de Comunicação Social não se manifeste no prazo de 30 (trinta) dias do recebimento das propostas de regulamento, estas serão consideradas referendadas pelo Conselho.

Art. 43. Esta Lei entra em vigor na data de sua publicação.

Brasília, 12 de setembro de 2011; $190^{\underline{0}}$ da Independência e $123^{\underline{0}}$ da República.

DILMA ROUSSEFF

José Eduardo Cardozo

Guido Mantega

Fernando Damata Pimentel

Miriam belchior

Paulo Bernardo Silva

Anna Maria Buarque de Hollanda

Aloizio Mercadante

Luís Inácio Lucena adams

Este texto não substitui o publicado no DOU de 13.9.2011 